MÁRCIA DE FREITAS OLIVEIRA

\title{
O PRINCÍPIO DA HUMANIDADE DAS PENAS E O ALCANCE DA PROIBIÇÃO CONSTITUCIONAL DE PENAS CRUÉIS
}

\author{
Dissertação de mestrado
}

Orientadora: Professora Associada Dra. Helena Regina Lobo da Costa

Faculdade de Direito da Universidade de São Paulo

São Paulo 


\title{
MÁRCIA DE FREITAS OLIVEIRA
}

\section{O PRINCÍPIO DA HUMANIDADE DAS PENAS E O ALCANCE DA PROIBIÇÃO CONSTITUCIONAL DE PENAS CRUÉIS}

\begin{abstract}
Dissertação apresentada à Banca Examinadora do Programa de Pós-graduação em Direito, da Faculdade de Direito da Universidade de São Paulo, como exigência parcial para obtenção do título de Mestre em Direito, na área de concentração Direito Penal, Medicina Forense e Criminologia, sob a orientação da Professora Associada Dra. Helena Regina Lobo da Costa.
\end{abstract}

Faculdade de Direito da Universidade de São Paulo

São Paulo 
Serviço de Biblioteca e Documentação Faculdade de Direito da Universidade de São Paulo

\section{Oliveira, Márcia de Freitas}

O $48 \mathrm{p} \quad$ O princípio da humanidade das penas e o alcance da proibição constitucional de penas cruéis / Márcia de Freitas Oliveira . -- São Paulo: USP / Faculdade de Direito, 2014.

$268 \mathrm{f}$.

Orientadora: Profa. Dra. Helena Regina Lobo da Costa Dissertação (Mestrado), Universidade de São Paulo, USP, Programa de Pós-Graduação em Direito, Direito Penal, Medicina Forense e Criminologia, 2014.

1. Penas (Direito penal). 2. Sanção. 3. Direitos humanos. 4. Direitos e Garantias Individuais. I. Costa, Helena Regina Lobo da. II. Título. 
OliveIRA, Márcia de Freitas. O Princípio da Humanidade das Penas e o Alcance da Proibição Constitucional de Penas Cruéis. Dissertação apresentada à Faculdade de Direito da Universidade de São Paulo para obtenção do título de Mestre em Direito Penal.

Aprovada em:

Banca examinadora

Prof. Dr. Instituição:

Julgamento: Assinatura:

Prof. Dr. Instituição:

Julgamento: Assinatura:

Prof. Dr. Instituição:

Julgamento: Assinatura: 


\section{AGRADECIMENTOS}

À Profa. Helena Regina Lobo da Costa, minha orientadora, pelo tempo e atenção dispensados durante os últimos três anos, e que possibilitou a realização deste trabalho.

Ao Prof. Sérgio Salomão Shecaira e ao Prof. Alamiro Velludo Salvador Netto, que compuseram minha banca de qualificação e que contribuíram com orientações que aclararam o caminho que deveria seguir.

Aos demais professores do Departamento de Direito Penal, Medicina Forense e Criminologia, da Faculdade de Direito da Universidade de São Paulo, que contribuíram para despertar meu interesse pela ciência penal.

À Universidade de São Paulo, pela oportunidade de realizar o curso de pós-graduação, ao Instituto Brasileiro de Ciências Criminais - IBCCRIM, espaço que foi imprescindível para o desenvolvimento deste trabalho, e à Coordenação de Aperfeiçoamento de Pessoal de Nível Superior - CAPES, pela concessão da bolsa de pesquisa.

Por fim, aos meus pais, Carmem e Donizeti, cujo apoio contribuiu para minha dedicação ao curso de pós-graduação e a este trabalho. 


\section{RESUMO}

OliveIRA, Márcia de Freitas. O princípio da humanidade das penas e o alcance da proibição constitucional de penas cruéis. 2014. 268f. Mestrado - Faculdade de Direito, Universidade de São Paulo, São Paulo, 2014.

Este trabalho tem por objetivo a análise do princípio da humanidade no Direito Penal Brasileiro e as violações a este princípio que ocorrem na aplicação de uma sanção criminal. Serão estudados alguns textos internacionais que contribuíram para o desenvolvimento deste princípio, bem como as consequências de sua adoção no ordenamento jurídico brasileiro, com a análise das penas que são proibidas pela Constituição Federal. Serão analisadas, também, a pena privativa de liberdade, a medida de segurança e a medida socioeducativa, que são alcançadas por este princípio, de modo a verificar como ocorrem as violações do princípio ora em estudo em cada uma dessas sanções. Ao fim, serão apresentadas essas violações de modo a compreender o papel que cada um dos operadores do Direito tem de proteção à dignidade e aos direitos fundamentais das pessoas que cometem infrações criminais.

Palavras Chave: Princípio da humanidade. Sanções penais. Penas proscritas. 


\begin{abstract}
OliveIRA, Márcia de Freitas. The principle of humanity of the criminal sanctions and the reach of the constitutional prohibition of cruel sanctions. 2014. 268p. Master - Faculty of law, University de São Paulo, São Paulo, 2014.

This paper aims at analyzing the principle of humanity in the Brazilian Criminal Law and the violations of this principle that occur in the application of criminal sanctions. Some international texts that contributed to the development of this principle will be studied, as well as the consequences of their adoption in the Brazilian legal system, with the analysis of the criminal penalties that are forbidden by the Federal Constitution. Will also be analyzed the penalty of deprivation of liberty, the involuntary psychiatric treatment and the socio-educational measures, which are reached by this principle, to check how the violations of the principle being studied occur in each of these sanctions. At the end, these violations will be presented in order to understand the role that each person has to protect the dignity and fundamental rights of the people who commit criminal offenses.
\end{abstract}

Key Words: Principle of humanity. Criminal sanctions. Prohibited sanctions. 


\section{SUMÁRIO}

Introdução

Capítulo 1. Princípio da Humanidade 12

1.1. Legislação internacional sobre o princípio da humanidade das penas .......... 13

1.1.1. Convenção Europeia de Direitos Humanos .............................................. 16

1.1.2. Pacto Internacional de Direitos Civis e Políticos ..................................... 18

1.1.3. Convenção Americana de Direitos Humanos ........................................... 19

1.1.4. Convenção contra Tortura e Outros Tratamentos ou Penas Cruéis, 23 Desumanos ou Degradantes

1.2. Conteúdo do princípio da humanidade ..................................................... 27

1.2.1 Dignidade da pessoa humana ................................................................ 27

1.2.2 Princípio da humanidade .................................................................. $\quad 30$

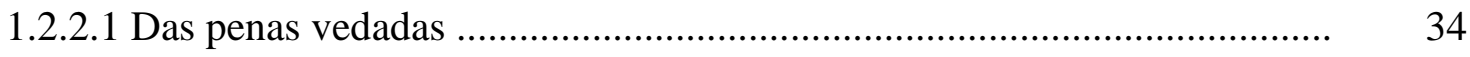

1.2.2.1.1 Pena de morte ................................................................................. 34

1.2.2.1.2 Penas e tratamentos cruéis, desumanos e degradantes ......................... 36

1.2.2.1.3 Prisão perpétua e penas de longa duração ............................................ 38

1.2.2.1.4 Pena de banimento e trabalhos forçados .............................................. 40

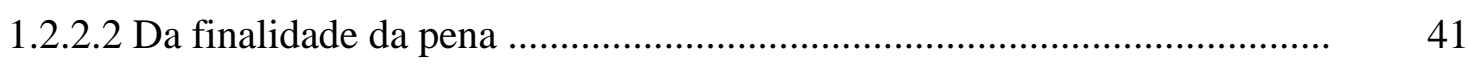

1.2.2.3. Outras incidências do princípio da humanidade ..................................... 43

Capítulo 2. Pena privativa de liberdade 46

2.1. A pena privativa de liberdade no Brasil .................................................... 46

2.1.1. Dos regimes de cumprimento de pena privativa de liberdade ................... 48

2.1.1.1. Da progressão e da regressão de regime ................................................ 52

2.1.2. Da substituição da pena privativa de liberdade por penas restritivas de 56 direitos

2.1.2.1. Da prestação pecuniária ..................................................................... $\quad 59$

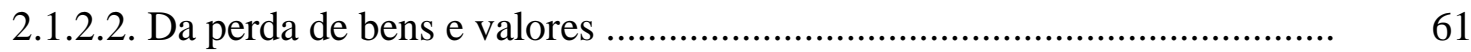

2.1.2.3. Da prestação de serviços à comunidade ou a entidades públicas ............ $\quad 62$

2.1.2.4. Da interdição temporária de direitos ..................................................... 64 
2.1.2.5. Da limitação de fim de semana

2.1.2.6. Da multa

2.1.3. Da suspensão da execução da pena privativa de liberdade ......................... 68

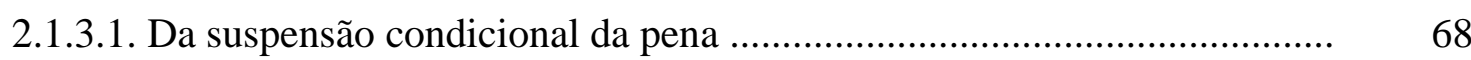

2.1.3.2. Do livramento condicional ............................................................. 71

2.2. Da execução da pena privativa de liberdade ................................................ 73

2.2.1. Lei de Execução Penal (Lei Federal no 7.210/1984) .................................

2.2.2. Dos direitos e deveres dos presos ............................................................ 88

2.2.2.1. Trabalho e remição ............................................................................ 91

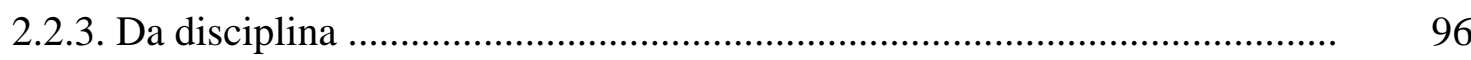

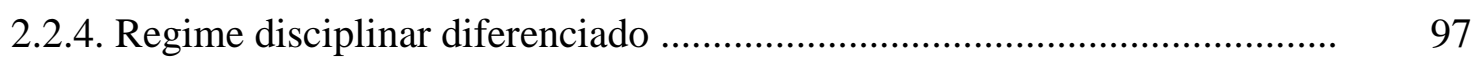

2.3. Da função ressocializadora da pena privativa de liberdade .......................... 103

Capítulo 3. Das medidas de segurança 111

3.1. A medida de segurança no ordenamento jurídico brasileiro ......................... 111

3.1.1. Das diferenças entre penas e medidas de segurança ................................ 114

3.1.2. Espécies de medida de segurança .......................................................... 117

3.1.3. Hipóteses de aplicação das medidas de segurança ................................... 119

3.2. Das garantias das medidas de segurança .................................................. 121

3.2.1. Do prazo indeterminado das medidas de segurança ................................... 123

3.2.2. O tratamento oferecido na medida de segurança e o objetivo de 130 reinserção social

3.2.2.1 Desinternação progressiva ................................................................. 135

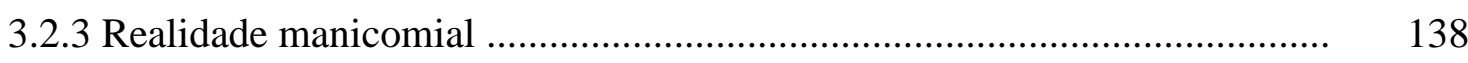

3.2.4. Tratamento coercitivo ..................................................................... 142

3.3. Reforma psiquiátrica ......................................................................... 143

Capítulo 4. Das medidas socioeducativas 151

4.1. A doutrina da proteção integral .................................................................. 151

4.2. O Estatuto da Criança e do Adolescente e o Direito Penal Juvenil ............... 156

4.2.1. A inimputabilidade penal ................................................................... 159

4.2.1.1. Das discussões acerca da redução da inimputabilidade penal ................ 161

4.2.2. Os direitos e garantias da criança e do adolescente em conflito com a lei.. 164 
4.2.3. $\mathrm{O}$ ato infracional

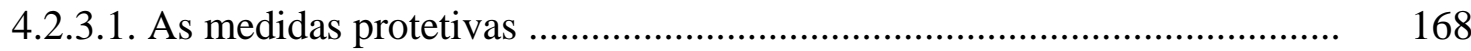

4.2.3.2. A remissão ................................................................................. 169

4.2.3.3. As medidas socioeducativas ........................................................... 171

4.2.3.3.1. Das medidas socioeducativas cumpridas em meio aberto ................... 175

4.2.3.3.1.1. Advertência ...................................................................................... 177

4.2.3.3.1.2. Obrigação de reparar o dano ........................................................... 178

4.2.3.3.1.3. Prestação de serviços à comunidade ................................................. 179

4.2.3.3.1.4. Liberdade assistida .................................................................... 181

4.2.3.3.2. Das medidas socioeducativas privativas de liberdade ........................ 182

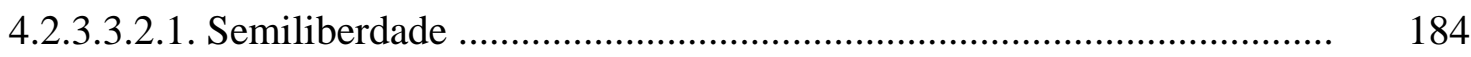

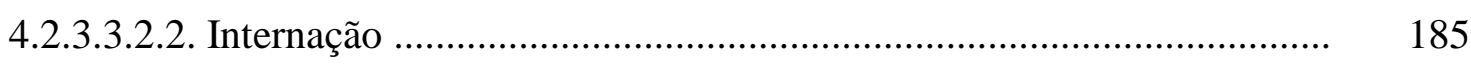

4.2.3.3.2.2.1. Internação provisória .................................................................. 190

4.3. Da aplicação e execução das medidas socioeducativas ................................. 191

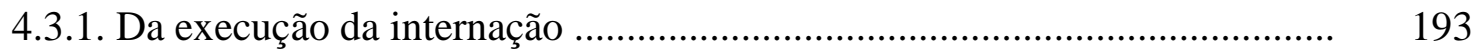

4.3.2. A aplicação da doutrina da situação irregular pelos tribunais .................... 201

4.4. A Unidade Experimental de Saúde ............................................................. 205

Capítulo 5. O princípio da humanidade e a privação de liberdade no Brasil 211

5.1. O alcance da proibição de penas cruéis ........................................................... 211

5.2. Violações ao princípio da humanidade ......................................................... 213

5.2.1. Penas e tratamentos cruéis, desumanos e degradantes ............................... $\quad 214$

5.2.2. Penas perpétuas e de longa duração ............................................................ 218

5.2.3. A finalidade da privação de liberdade .................................................... 222

5.3.4. Do respeito à dignidade humana ........................................................... 228

5.3. Do respeito ao princípio da humanidade no Brasil ........................................ 230

Conclusões $\quad 235$

Referências $\quad 242$ 


\section{INTRODUÇÃO}

O presente trabalho analisa o princípio da humanidade das penas e sua aplicação no Direito Penal Brasileiro. Tem por objetivo verificar a incidência deste princípio no ordenamento penal, em relação às penas que são proibidas e em relação às quais espécies de sanções ele se aplica.

Até o século XVIII, as penas criminais tendiam a ser corporais e excessivamente aflitivas, sendo uma expiação pelo mal causado pelo infrator e servindo para reafirmar o poder estatal. Após o advento das ideias iluministas e da Revolução Francesa, tem-se uma nova concepção a respeito do homem e dos direitos inerentes a ele.

Reconhece-se, desta forma, que toda pessoa é possuidora de dignidade, que deve ser protegida pelo Estado, da qual decorrem direitos fundamentais, cuja realização deve ser possibilitada a todas as pessoas. A partir desses ideais, a privação de liberdade, que antes era apenas uma forma de custódia do condenado até a aplicação da pena definitiva, passa a ser utilizada como uma espécie de pena, na qual a restrição desse direito constitui-se a pena criminal.

Isso permitiu o desuso das penas excessivamente aflitivas, que foram substituídas pela privação de liberdade, notando-se, assim, uma humanização do Direito Penal. Verificou-se, também, uma nova finalidade que se tentou atribuir à pena, tendo em vista que, além de desestimular a sociedade a cometer novos crimes, a sanção criminal também deveria atuar sobre o condenado, ressocializando-o, de modo a permitir o retorno dele ao convívio social.

Concomitantemente a essa humanização, surgem textos internacionais que se preocupam com o reconhecimento e proteção da dignidade de cada pessoa. Em razão deste 
reconhecimento, esses textos passam a estabelecer limites à pena privativa de liberdade, os quais o Estado deve respeitar.

O Brasil, que ratificou diversos tratados sobre a proteção dos direitos humanos, adotou, na Constituição Federal de 1988, o respeito à dignidade humana, bem como o princípio da humanidade das penas. Contudo, é notório o cenário de abandono dos cárceres brasileiros, onde os direitos fundamentais dos presos são desrespeitados.

É neste cenário de violações ao princípio da humanidade na imposição das sanções criminais que se desenvolve o presente trabalho, sendo ele dividido em três partes.

Primeiramente, analisar-se-á o princípio da humanidade das penas. Vários textos internacionais trouxeram a preocupação com a proteção da dignidade humana e com o princípio ora em estudo, contribuindo para o desenvolvimento deste princípio. O princípio da humanidade das penas se desdobra, em nossa legislação, em especial na Constituição Federal, em algumas faces, que estabelecem os tipos de penas e de tratamentos que são proibidos no ordenamento jurídico penal. Assim, serão estudadas essas faces, bem como alguns textos internacionais que contribuíram para esse desenvolvimento e as espécies de penas proibidas pelo texto constitucional.

Na segunda parte do trabalho, serão analisadas as consequências possíveis do crime que importam em privação de liberdade - pena privativa de liberdade, medidas de segurança e medidas socioeducativas - e abordada a execução de cada uma dessas medidas previstas em lei. Em decorrência do princípio da legalidade, todas as medidas citadas acima devem estar previstas em lei, assim como as suas especificidades, indicando o destinatário da medida, o tempo de duração delas e como deve ser sua execução. Mas, a execução de uma pena criminal não corresponde à legislação que a regulamenta, sendo os estabelecimentos penais locais degradados, de onde não resultam efeitos positivos. Além disso, alguns institutos passam por interpretação judicial antes de sua aplicação, podendo resultar em mais violações de direitos das pessoas submetidas a uma sanção criminal. Assim, além da previsão legal dessas sanções, também serão estudados o entendimento jurisprudencial acerca de algumas questões e a forma como, de fato, são executadas a pena 
privativa de liberdade, a medida de segurança e a medida socioeducativa. Para isso, serão analisados relatórios elaborados por órgãos governamentais e não governamentais a respeito da situação carcerária do Brasil, além da legislação e alguns julgados sobre o tema.

Durante esta abordagem, serão apontados os casos em que ocorre violação ao princípio da humanidade para cada uma dessas sanções de acordo com o estudo realizado na primeira parte do trabalho. Em relação à medida socioeducativa, será analisada a proteção especial dada pela Constituição Federal aos adolescentes, motivo pelo qual seu tratamento deve se dar mediante a doutrina da proteção integral, adotada pelo Estatuto da Criança e do Adolescente. Já em relação à medida de segurança, será apresentada a Lei Federal $n^{\circ} 10.216 / 2001$, que determinou a reforma psiquiátrica brasileira e deu uma nova abordagem à internação psiquiátrica, cujos preceitos deveriam ser adotados, também, para a sanção penal direcionada ao inimputável.

Ao fim, será abordado o alcance do princípio da humanidade em nossa legislação, tanto em relação às penas proibidas, quanto no que tange aos destinatários deste princípio. Além de proibir a adoção de determinados tipos de penas, o princípio da humanidade estabelece limites para a pena privativa de liberdade e outras formas de sanções que importem em privação deste direito. Assim, após a análise das formas de privação de liberdade presentes em nosso ordenamento, as violações descritas na parte anterior do trabalho serão analisadas conjuntamente, aproximando aquelas que atingem a mesma face deste princípio ou que atingem diretamente a dignidade do condenado. Será demonstrado que essas violações podem ocorrer de diversas formas, como, por exemplo, através de um entendimento jurisprudencial não condizente com o princípio ora em estudo, e não apenas na execução da pena.

O trabalho, portanto, pretende asseverar que as violações aos direitos fundamentais dos presos não se dá apenas em razão da falta de estrutura física e humana dos estabelecimentos penais, nem apenas no cumprimento da pena privativa de liberdade, mas, também, no cumprimento de outras sanções criminais e em razão da interpretação e aplicação da lei penal, bem como de sua elaboração legislativa. 


\section{CAPÍTULO 1. PRINCÍPIO DA HUMANIDADE}

Com o início da era contemporânea, a partir do século XVIII, após a Revolução Francesa, e com a influência do movimento iluminista, o Direito Penal, que era marcado por sua crueldade, humaniza-se e a pena privativa de liberdade consolida-se como forma de punir, em substituição às penas excessivamente aflitivas, sendo isto uma reação aos movimentos de humanização e reforma das penas ${ }^{1}$.

Além de postular direitos inerentes à condição humana, o Iluminismo trouxe uma nova concepção de Estado, na qual os direitos humanos seriam respeitados e assegurados ${ }^{2}$.

A adoção desta nova concepção, fundada em princípios humanitários, é um marco divisor da história do Direito Penal e da humanização das penas. A sanção penal deixa de ter um cunho meramente punitivo e retributivo e assume um papel mais educativo e ressocializador $^{3}$. Ela também passa a ficar vinculada a leis prévias e certas, limitada ao mínimo necessário; e as sanções degradantes passam a ser proibidas.

Anteriormente, na monarquia, as penas, que eram cruéis, também tinham por finalidade atemorizar a população e reafirmar o poder do soberano. Era comum, ainda, a prática de arbitrariedades pelas instituições absolutistas ${ }^{4}$.

\footnotetext{
${ }^{1}$ Martos NúÑEZ, Juan Antonio. Principios penales en el estado social y democrático de derecho. Revista de Derecho Penal y Criminología, Madrid, n. 1, p. 286-289, 1991.

${ }^{2}$ LuISI, Luiz. O princípio da humanidade. Revista da Escola do Serviço Penitenciário do Rio Grande do Sul, Porto Alegre, n. 8, p. 147-148, jul./set. 1991.

3 RoBALDO, José Carlos de Oliveira. Penas e medidas alternativas: reflexões político-criminais. Rio de Janeiro: Juarez de Oliveira, 2007. p. 97-101.

${ }^{4}$ LimA, Carolina Alves de Souza; MARQUES, Oswaldo Henrique Duek. O princípio da humanidade das penas. In: MirandA, Jorge; Silva, Marco Antonio Marques da (Coords.). Tratado luso-brasileiro da dignidade humana. 2. ed. São Paulo: Quartier Latin, 2009. p. 440-442.
} 
1.1. Legislação internacional sobre o princípio da humanidade das penas

No âmbito da legislação mundial, surgem textos que se preocupam com a proteção dos direitos humanos e que fazem expressa referência à proibição da tortura e da aplicação de tratamentos e penas cruéis. A partir da ratificação desses textos, os Estados têm a obrigação de punir estes atos, pois constituem sérios ataques à dignidade humana ${ }^{5}$.

A primeira legislação, adotada antes mesmo da Revolução Francesa, que se destaca por conter tal preocupação é a Declaração dos Direitos do Homem da Virgínia, EUA, de 1776, onde houve o veto quanto à aplicação de penas cruéis e desusadas, proibição que também foi prevista na Constituição dos Estados Unidos, de 1787, em seu artigo $7^{\circ}$, e na Emenda VIII desta Constituição, de 1791.

Em sequência, após a Revolução Francesa, foi elaborada a Declaração dos Direitos do Homem e do Cidadão, em 1789, que, ao dispor sobre os direitos universais, individuais e coletivos, do homem, estabeleceu, em seu artigo $9^{\circ}$, que todo rigor desnecessário na aplicação das penas deve ser severamente reprimido por lei.

Essa Declaração inaugura a era da universalização dos direitos do homem, com base numa nova concepção do homem no universo, a qual estabelece que toda pessoa tem direitos inerentes a sua condição humana ${ }^{6}$.

Surge, então, no Direito Internacional, o primeiro conjunto de normas, tanto consuetudinárias quanto convencionais, que proíbem a tortura e quaisquer penas ou tratamentos desumanos, degradantes ou cruéis ${ }^{7}$.

\footnotetext{
5 STEINER, Sylvia Helena. A prevenção do crime de tortura no cenário do direito internacional. Revista Brasileira de Ciências Criminais, São Paulo, v. 99, p. 305-311, nov./dez. 2012.

${ }^{6}$ LIMA, Carolina, 2009, p. 440-442.

${ }^{7}$ STEINER, op. cit., p. 301.
} 
Esse sistema internacional de direitos humanos pró́be o Estado de interferir ilegitimamente na dignidade do ser humano - que está vinculada a sua integridade pessoal, física ou psicológica - por meio da prática da tortura e de outras formas de tratamentos ou penas cruéis, desumanos e degradantes ${ }^{8}$. Com o fim das penas demasiadamente aflitivas, as declarações proclamaram a necessidade de encontrar uma forma humana e justa de punir, devendo a pena ser a necessária e suficiente, proporcional ao delito cometido, e observados os princípios humanitários na execução da sanção imposta ${ }^{9}$.

Nos textos adotados após a Declaração dos Direitos do Homem e do Cidadão, a proteção à dignidade humana mostrou-se presente também para os prisioneiros de guerra, tendo em vista que mesmo nesta situação a dignidade das pessoas ainda é um valor indisponível ${ }^{10}$. Primeiramente, têm-se as Convenções de Haia, de 1899 e 1907, que dispuseram sobre os crimes de guerra.

Em seguida, a terceira Convenção de Genebra, de 1929, dispondo sobre Direitos Humanos Internacionais, estabeleceu uma proteção geral aos prisioneiros de guerra. Em seu artigo 13, determina que aos prisioneiros de guerra deve ser dispensado, a todo tempo, um tratamento humano, e respeitada sua dignidade. Este artigo determina, ainda, a proteção à integridade física das pessoas nesta situação, que estes devem ser protegidos contra qualquer forma de violência, insultos ou curiosidade pública, e a proibição de represálias contra esses prisioneiros.

Ainda, no artigo $3^{\circ}$, comum às quatro Convenções de Genebra, estabeleceu-se que atos de violência contra a vida, mutilação, tratamento cruel, tortura, suplícios, ofensa à dignidade, tratamento humilhante ou degradante, são e permanecerão proibidos em qualquer momento e em qualquer lugar ou circunstância, protegendo-se, também, as pessoas que não tomam parte, diretamente, de conflitos armados, como, por exemplo, os membros das forças armadas que tenham deposto as armas e as pessoas que tenham sido postas para fora de combate por doença, ferimentos, detenção, ou por qualquer outra causa.

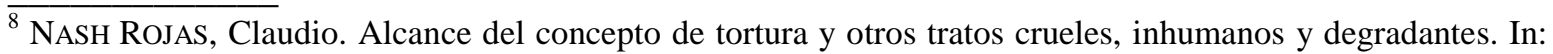
ElSNER, Gisela (Ed.). Anuario de derecho constitucional latinoamericano 2009. Montevidéu: KonradAdenauer-Stiftung, 2009. p. 586-589.

${ }^{9}$ LIMA, Carolina, 2009, p. 440-442.

${ }^{10}$ Steiner, 2012, p. 301-303.
} 
E, no artigo 27, da $4^{\text {a }}$ Convenção de Genebra, de 1949, relativa à proteção das pessoas civis em tempos de guerra, da mesma forma que para os prisioneiros, também há a obrigação para os Estados de tratar com humanidade os civis, protegendo-os de atos de violência e de intimidação, de insultos e da curiosidade pública.

Em 1945, cria-se a Organização das Nações Unidas, cujo objetivo era a busca da paz, da cooperação e solução dos problemas internacionais, sempre respeitando os direitos humanos. Com esta organização, admite-se que a proteção dos direitos da pessoa não se esgota na competência nacional de cada Estado, sendo necessário um órgão para a proteção internacional desses direitos, pois o respeito ao ser humano e a sua dignidade passam a ser a base dessa nova ordem jurídica internacional ${ }^{11}$.

Três anos depois, a Declaração Universal dos Direitos Humanos, proclamada pela Assembleia Geral das Nações Unidas, em 1948, reconheceu, em seu preâmbulo, que a dignidade inerente a todo ser humano é o fundamento da liberdade, da justiça e da paz no mundo e que os direitos e liberdades inerentes às pessoas devem ser assegurados e observados tanto em caráter nacional quanto em caráter internacional.

Em seu artigo $5^{\circ}$, há a expressa previsão de que ninguém pode ser submetido à tortura, nem a tratamento ou castigo cruel, desumano ou degradante.

Essa declaração, juntamente com as demais que tratam dos direitos inerentes a todas as pessoas, sobretudo as que foram proclamas após a Segunda Guerra Mundial, passam a fazer parte de um Direito Internacional Humanitário, internacionalizando, desta forma, os Direitos Humanos e a obrigação dos Estados de resguardá-los.

Vários outros pactos e convenções internacionais foram assinados proibindo as penas e tratamentos cruéis, desumanos e degradantes, além de estabelecerem a tortura como um delito internacional, impondo aos Estados o dever de reprimi-la. Estes outros textos também proíbem os Estados de restringir ou suspender, em qualquer circunstância,

\footnotetext{
${ }^{11}$ LIMA, Carolina, 2009, p. 440-442.
} 
mesmo em situações de emergência, os direitos por eles trazidos ${ }^{12}$. As constituições dos Estados também passam a elencar os direitos e princípios trazidos pelos textos internacionais, como o princípio da humanidade, entre outros, como direitos de seus cidadãos.

\subsubsection{Convenção Europeia de Direitos Humanos}

A Convenção para a Proteção dos Direitos do Homem e das Liberdades Fundamentais, também conhecida como Convenção Europeia de Direitos Humanos, foi assinada em 1950, com o objetivo de aplicar e efetivar os direitos enunciados na Declaração Universal dos Direitos do Homem (1948), conforme dispõe em seu preâmbulo.

Essa convenção, em seu artigo $2^{\circ}$, garante o direito à vida a qualquer pessoa, salvo em casos de aplicação da pena de morte, pena permitida no texto principal desta convenção ${ }^{13}$. O direito à vida também é excepcionado, neste mesmo artigo, em outras situações, tais como: para assegurar a defesa de qualquer pessoa contra uma violência ilegal, para efetuar uma detenção legal ou para impedir a evasão de uma pessoa detida legalmente, e para reprimir, em conformidade com a lei, uma revolta ou uma insurreição.

O Protocolo nº 6, da Convenção Europeia de Direitos Humanos, assinado em 1983, relativo à abolição da pena de morte, inova o texto da Convenção ao estabelecer, em seu artigo $1^{\circ}$, a abolição da pena de morte, não podendo mais esta ser aplicada ou executada nos países que ratificarem este protocolo, exceto nos casos de guerra, situação em que ela ainda é permitida, conforme o artigo $2^{\circ}$, deste documento ${ }^{14}$.

\footnotetext{
${ }^{12}$ NASH ROJAS, 2009 , p. 586-589.

${ }^{13}$ No caso Bader e Kanbor vs. Suécia, a Corte Europeia de Direitos Humanos entendeu que poderia haver violação quanto ao artigo 2, da Convenção Europeia de Direitos Humanos, caso o governo sueco efetivasse a medida de deportação de Bader para a Síria, pois lá poderia ser executada a pena de morte a qual ele foi condenado em sentença proferida que não atendeu às garantias processuais. No caso, a pena de morte foi imposta em julgamento sem sua presença, onde o requerente não pode exercer os direitos à defesa e a um julgamento justo (CORTE Europeia de Direitos Humanos. Caso Bader e Kanbor Vs. Suécia, de 8 de novembro de 2005, disponível em <http://hudoc.echr.coe.int/sites/eng/pages/search.aspx?i=001-70841>, acesso em 16.06.2014).

${ }^{14}$ Dos países signatários da Convenção Europeia de Direitos Humanos, apenas a Rússia ainda não ratificou este protocolo.
} 
Já o Protocolo $\mathrm{n}^{\circ}$ 13, de 2002, de modo a reforçar e proteger o direito à vida e reconhecer plenamente a dignidade inerente a todas as pessoas, aboliu a pena morte, inclusive na situação excepcionada pelo Protocolo $n^{\circ}$, não podendo mais os Estados signatários desse documento aplicar ou executar a pena capital, qualquer seja a situação ${ }^{15}$.

No tocante ao tratamento dispensado aos presos, o artigo $3^{\circ}$ desta convenção, além de proibir a tortura, proíbe penas e tratamentos desumanos e degradantes ${ }^{16}$.

Por tratamento desumano, deve-se entender aquele que causa, deliberadamente, severo sofrimento mental ou físico, de maneira injustificada; por tortura, o tratamento desumano, causado com uma intenção, como, por exemplo, obter informações ou confissões, ou infligir um castigo, sendo, geralmente, uma forma de tratamento desumano agravado; e, por tratamento degradante, entende-se aquele que humilha, de maneira grave, perante terceiros, ou aquele que leva o indivíduo a atuar contra a sua vontade ou consciência $^{17}$.

O trabalho exigido normalmente de uma pessoa submetida à detenção ou em liberdade condicional não é considerado trabalho forçado ou obrigatório, conforme dispõe o artigo 4.3, alínea "a", desta convenção.

Ao final, em seu artigo 15.2, a Convenção Europeia estabelece que as disposições citadas acima, em relação ao direito à vida e à proibição da tortura e penas e tratamentos desumanos ou degradantes, salvo a morte resultante de atos lícitos de guerra, não podem ser derrogadas em caso de estado de necessidade, como guerra ou outro perigo público que ameace a nação.

\footnotetext{
$\overline{15}$ Dos países signatários desta convenção, a Rússia e o Azerbaijão não assinaram este protocolo, e a Armênia e a Polônia, apesar de o terem assinado, ainda não o retificaram.

${ }^{16}$ Ao julgar o caso Vinter e outros vs. Reino Unido, a Corte Europeia de Direitos Humanos entendeu que a prisão perpétua não se caracteriza uma pena desumana ou degradante, desde que o condenado a esta pena vislumbre alguma possibilidade de sua revisão. A Corte entendeu, ainda, que, para não haver violação ao artigo $3^{\circ}$, da Convenção, o prazo máximo para revisão da pena de prisão perpétua deve ser de 25 anos (CORTE EuRopeia DE Direitos Humanos. Caso Vinter e outros Vs. Reino Unido, de 9 de julho de 2013, disponível em <http://hudoc.echr.coe.int/sites/fra/pages/search.aspx?i=001-122664>, acesso em 16.06.2014).

${ }^{17}$ Corte Europeia de Direitos Humanos. The Greek Case. In: Yearbook of the European Convention on Human Rights, nº 12, 1969. Martinus Nÿhoff, 1972. p. 186.
} 


\subsubsection{Pacto Internacional de Direitos Civis e Políticos}

Adotado em 1966, pela Assembleia-Geral das Nações Unidas, este tratado internacional estabelece direitos que devem ser resguardados pelo Estado e que são decorrentes da dignidade inerente à pessoa, cujo reconhecimento é o fundamento da liberdade, da justiça e da paz no mundo.

Conforme enuncia seu preâmbulo, juntamente com a Declaração Universal dos Direitos Humanos (1948), este pacto tem por objetivo propiciar as condições necessárias para que as pessoas gozem seus direitos civis e políticos, bem como seus direitos econômicos, sociais e culturais, tendo em vista que, conforme a declaração citada acima, é imposta aos Estados a obrigação de promover o respeito universal e efetivo dos direitos e das liberdades da pessoa.

Mais amplo que a Convenção Europeia de Direitos Humanos, este pacto prevê, em seu artigo $10^{\circ}$ e parágrafos, que toda pessoa privada de sua liberdade deverá ser tratada com humanidade e respeito à dignidade inerente a ela. Prevê, ainda, que a pessoa presa provisória ou preventivamente deverá ser tratada de modo distinto da pessoa condenada; e estabelece que o objeto do tratamento penitenciário deve ser a reforma e a reabilitação moral dos prisioneiros.

Ainda sobre o tratamento que deve ser dispensado às pessoas privadas de sua liberdade, o artigo $7^{\circ}$, do pacto, proíbe a tortura e a submissão de pessoas a penas ou tratamentos cruéis, desumanos ou degradantes, complementado, ainda, pela proibição de submeter alguém, sem seu consentimento, a experiências médicas ou científicas ${ }^{18}$.

\footnotetext{
${ }^{18}$ Conforme o Comitê de Direitos Humanos das Nações Unidas, para diferenciar o tratamento desumano e o degradante, é necessário analisar todas as circunstâncias do caso, como a duração e forma do tratamento, bem como suas consequências, como, por exemplo, os efeitos físicos ou mentais causados na pessoa. Também devem ser analisadas as características pessoais do detento, como idade, sexo e estado de saúde (OrganizaÇÃo das NAÇões UnIDAS. Comitê de Direitos Humanos. Comunicación no 265/1987: Finland. 02/05/1989/ CCPR/C/35/D/265/1987, disponível em <http://www1.umn.edu/humanrts/hrcommittee/spanish/265-1987.html>, acesso em 19.06.2014). E para diferenciar um tratamento desumano ou degradante da tortura, deve-se considerar, além da severidade do
} 
O direito à vida está previsto no artigo $6^{\circ}$. No primeiro parágrafo deste artigo, determina-se que este direito deve ser protegido por lei e ninguém poderá, arbitrariamente, ser dele privado.

Em relação à pena de morte, esta é admitida neste pacto, conforme previsão do artigo 6.2, desde que imposta somente nos casos de crimes mais graves, sendo decorrente de sentença transitada em julgado, proferida por tribunal competente, e deve, ainda, respeitar as disposições deste Pacto e da Convenção sobre a Prevenção e a Repressão do Crime de Genocídio, de 1948. No parágrafo $4^{\circ}$ deste artigo, é assegurada, também, aos condenados à pena de morte, a possibilidade de concessão de anistia, indulto e comutação da pena.

Não podem ser condenados à morte, de acordo com o artigo 6.5, menores de 18 anos, e esta pena não pode ser executada em mulheres grávidas.

No $2^{\circ}$ Protocolo Facultativo a este pacto, abole-se a pena de morte para os países signatários deste documento, podendo, estes, fazer reserva no momento da ratificação do protocolo quanto à pena de morte aplicada em tempo de guerra e por infração penal de natureza militar de gravidade extrema.

Da mesma forma que a Convenção Europeia de Direitos Humanos, o artigo $8^{\circ}$, parágrafo $3^{\circ}$, alíneas " $b$ " e "c", estabelece que é lícito exigir serviços ou trabalhos de uma pessoa que esteja encarcerada ou em liberdade condicional, em decorrência de uma decisão judicial.

\subsubsection{Convenção Americana de Direitos Humanos}

A Convenção Americana de Direitos Humanos, de 1969, também conhecida como Pacto de São José da Costa Rica, consolida, no continente americano, um regime de liberdade pessoal e justiça social, fundado no respeito dos direitos essenciais do homem,

tratamento recebido pelo detento, outros elementos, como a intencionalidade e finalidade do ato praticado (NASH ROJAS, 2009, p. 600). 
que são decorrentes da própria condição de ser humano e não do fato de ser nacional de determinado país, conforme o disposto em seu preâmbulo ${ }^{19}$. No artigo 11 , da presente convenção, é garantido o direito às pessoas ao respeito de sua honra, bem como o reconhecimento de sua dignidade, valor com o qual o Estado deve atuar de modo compatível.

Esta convenção tem o objetivo de criar condições que permitam a cada pessoa usufruir de seus direitos econômicos, sociais e culturais, assim como de seus direitos civis e políticos para alcançar o ideal de ser humano livre.

Como nas demais convenções, a proteção à vida é um dos primeiros direitos trazidos pelo texto, em seu artigo $4^{\circ}$, que dispõe que nenhuma pessoa será, arbitrariamente, privada do direito à vida. Ainda, no parágrafo $2^{\circ}$ deste artigo, foi estabelecido que a pena de morte só pode ser aplicada em casos de crimes mais graves, decorrente de sentença transitada em julgado, proferida por um tribunal competente.

Nos parágrafos seguintes deste artigo, ainda em relação à pena de morte, estabeleceu-se que esta pena não pode ser estendida para delitos aos quais ela não é cominada atualmente, e não pode ser restabelecida nos países em que já foi abolida ${ }^{20}$. Ainda, não pode ser aplicada a delitos políticos, nem comuns conexos a políticos; não pode

\footnotetext{
$\overline{19}$ Ratificaram esta convenção os seguintes países americanos: Argentina, Barbados, Bolívia, Brasil, Chile, Colômbia, Costa Rica, Dominica, Equador, El Salvador, Grenada, Guatemala, Haiti, Honduras, Jamaica, México, Nicaragua, Panamá, Paraguai, Peru, República Dominicana, Suriname, Trindad \& Tobago, Uruguai e Venezuela.

${ }^{20}$ No Parecer Consultivo OC-3/83, de 08.09.1983, formulado pela Comissão Interamericana de Direitos Humanos, em razão de o Estado da Guatemala fazer uma reserva ao ratificar a convenção no tocante à segunda parte do artigo 4.4 que pró́be a adoção da pena de morte para os crimes comuns conexos a crimes políticos, foi questionada a possibilidade de um Estado que ratificou a Convenção adotar a pena de morte para os delitos que não previam a cominação desta pena no momento em que a convenção passou a vigorar para o Estado, e a possibilidade de um Estado, tendo como base uma reserva realizada ao ratificar a convenção, como a que fez a Guatemala, adotar, posteriormente à vigência da convenção, a pena de morte a delitos que não previam esta pena no momento da ratificação da convenção, mas que estariam excepcionados pela reserva feita. A Corte Interamericana de Direitos Humanos respondeu aos questionamentos, afirmando, para a primeira questão, que um Estado não pode adotar a pena de morte para um delito que não a previa antes da vigência da convenção para o país; e, à segunda questão, respondeu que uma reserva realizada no momento da ratificação da convenção não permite ao Estado legislar, posteriormente, de modo a cominar a pena de morte a delitos que não a previam anteriormente à vigência da Convenção, mesmo que esses delitos estejam excepcionados por uma reserva feita no momento da ratificação (CORTE INTERAMERICANA DE DIREITOS Humanos. Parecer Consultivo OC-3/83, de 8 de setembro de 1983, Série A, No. 3, disponível em <http://www.corteidh.or.cr/docs/opiniones/seriea_03_esp.pdf>, acesso em 16.06.2014).
} 
ser imposta a menores de 18 anos, na data da perpetração do crime, ou a maiores de 70 anos, nem pode ser aplicada em mulheres grávidas.

Por fim, é garantida a possibilidade de anistia, indulto ou comutação da pena aos condenados à pena capital, sendo que a pena não pode ser executada enquanto houver pedido pendente ante a autoridade competente.

No Protocolo adicional desta convenção, referente à abolição da pena de morte, os Estados signatários deste documento abolem a pena de morte em seus territórios, tendo em vista o direito que toda pessoa tem de que se respeite sua vida, sem que este direito seja suspenso por motivo algum ${ }^{21}$. Para a elaboração deste documento, considerou-se, também, que o desenvolvimento desta convenção deve ser sempre progressista, que a pena de morte é irreparável quanto a erros judiciários e que esta pena elimina qualquer possibilidade de emenda e de reabilitação do condenado.

Contudo, é permitido àqueles países que ratificarem este protocolo fazer reserva quanto à pena de morte aplicada em tempo de guerra, de acordo com o Direito Internacional, por delitos graves de caráter militar, conforme artigo 2, parágrafo 1, do documento.

Também é previsto, na Convenção Americana de Direitos Humanos, o direito ao respeito à integridade física, psíquica e moral de qualquer pessoa. Conforme o artigo 5 e parágrafos, da convenção, ninguém deve ser submetido a tortura, nem a penas ou tratamentos cruéis, desumanos ou degradantes ${ }^{22}$. É previsto, também, que toda pessoa privada de liberdade deve ser tratada com o respeito devido à dignidade inerente do ser humano.

\footnotetext{
${ }^{21}$ Ratificou este protocolo adicional apenas os seguintes países: Argentina, Brasil, Chile, Costa Rica, Equador, Honduras, México, Nicaragua, Panamá, Paraguai, República Dominicana, Uruguai e Venezuela.

${ }^{22} \mathrm{Da}$ mesma forma que o Comitê de Direitos Humanos das Nações Unidas, no caso Bueno Alves vs. Argentina, julgado pela Corte Interamericana de Direitos Humanos, em 11 de maio de 2007, a Corte estabeleceu que para aferir se determinada pessoa foi submetida a um severo sofrimento físico ou mental, é necessário considerar as características do tratamento, tais como duração, método e modo empregados, e efeitos físicos e mentais causados na pessoa. Também devem ser analisadas as condições da pessoa, como idade, sexo, saúde, e outras circunstâncias pessoais (CORTE INTERAMERICANA DE DIREITOS HUMANOS. Caso Bueno Alves Vs. Argentina, de 11 de maio de 2007, disponível em <http://www.corteidh.or.cr/docs/casos/articulos/seriec_164_esp.pdf>, acesso em 16.06.2014).
} 
Há a previsão, ainda, nesta convenção, de que os detentos provisórios ou preventivos devem ficar separados dos detentos já condenados, salvo em circunstâncias excepcionais; e devem ser submetidos a tratamento adequado a sua condição de pessoas não condenadas ${ }^{23}$.

Considerando o teor do disposto no artigo 5.6, da convenção, a pena privativa de liberdade deve ter por finalidade, essencialmente, a reforma e a readaptação social dos condenados.

Igualmente ao Pacto Internacional de Direitos Civis e Políticos, conforme artigo 6, parágrafos 2 e 3, alínea "a", da convenção, é permitida a pena de trabalho obrigatório ao recluso, desde que imposto por juiz ou tribunal competente, com a ressalva que esta não afete a dignidade nem a capacidade física ou intelectual do recluso.

Por fim, conforme o artigo 27.2, da convenção, os direitos enunciados nos artigos $4^{\circ}$ (direito à vida), $5^{\circ}$ (proibição da tortura e penas ou tratamentos cruéis, desumanos e degradantes) e $6^{\circ}$ (possibilidade de impor pena de trabalhos obrigatórios ao recluso, com as ressalvas citadas acima) não podem ser suspensos em casos de guerra, perigo público ou qualquer outra emergência que ameace a independência ou segurança do Estado-parte.

\footnotetext{
${ }^{23}$ No caso Yvon Neptune Vs. Haiti, julgado pela Corte Interamericana de Direitos Humanos, a Corte considerou que houve violação ao artigo 5, parágrafos 1, 2 e 4, da convenção, pois Yvon Neptune, detento ainda não condenado, ficou recluso junto com outros detentos já condenados, e porque, durante o encarceramento, foi submetido a condições que não satisfaziam requisitos mínimos do tratamento que deveria ser dispensado a uma pessoa. As condições que a vítima foi submetida na Penitenciária Nacional do Haiti constituiu tratamento desumano e degradante e violou sua integridade física, tendo em vista a falta de ventilação e iluminação das celas, a insegurança do local, mantendo-o em estado permanente de medo, tanto dos agentes penitenciários quanto de outros detentos, a falta de cuidados e tratamentos médicos, as condições precárias de sua cela, em relação a tamanho, insalubridade, presença de insetos e animais, colchão fino e sujo, precariedade das instalações sanitárias e condições higiênicas, a falta de água e de alimentos nutritivos adequados, e a impossibilidade de fazer exercícios físicos e atividades recreativas, pois sofria ameaças e temia que, se saísse da cela, sua integridade física não seria resguardada (CORTE INTERAMERICANA DE DIREITOS Humanos. Caso Yvon Neptune Vs. Haiti, de 6 de maio de 2008, disponível em <http://www.corteidh.or.cr/docs/casos/articulos/seriec_180_esp1.pdf>, acesso em 16.06.2014).
} 
1.1.4. Convenção contra Tortura e Outros Tratamentos ou Penas Cruéis, Desumanos ou Degradantes

A Assembleia Geral das Nações Unidas adotou, em 1984, a Convenção contra Tortura e Outros Tratamentos ou Penas Cruéis, Desumanos ou Degradantes com o objetivo de tornar mais eficaz a luta contra essas condutas no mundo todo.

De acordo com o preâmbulo desta convenção, esse texto foi elaborado tendo em consideração que essas proibições emanam da dignidade inerente da pessoa, que é um bem jurídico que merece tutela penal, e também em conformidade com o artigo $5^{\circ}$, da Declaração Universal dos Direitos do Homem (1948), e com o artigo $7^{\circ}$, do Pacto Internacional sobre Direitos Civis e Políticos, que determinam que ninguém será sujeito a tortura ou a outros tratamentos e penas cruéis, desumanas e degradantes ${ }^{24}$.

Decorre, ainda, esta convenção, da Declaração sobre a Proteção de Todas as Pessoas contra a Tortura e outros Tratamentos ou Penas Cruéis, Desumanos ou Degradantes, adotada, em 1975, pela Assembleia Geral das Nações Unidas.

Logo em seu artigo $1^{\circ}$, a Convenção contra Tortura e Outros Tratamentos ou Penas Cruéis, Desumanos ou Degradantes traz a definição de tortura como sendo:

“(...) qualquer ato pelo qual dores ou sofrimentos agudos, físicos ou mentais, são infligidos intencionalmente a uma pessoa a fim de obter, dela ou de terceira pessoa, informações ou confissões; de castiga-la por ato que ela ou terceira pessoa tenha cometido ou seja suspeita de ter cometido; de intimidar ou coagir esta pessoa ou outras pessoas, ou por qualquer motivo baseado em discriminação de qualquer natureza; quando tais dores ou sofrimentos são

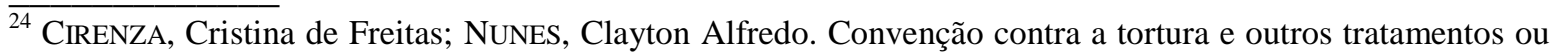
penas cruéis, desumanas ou degradantes e convenção interamericana para prevenir e punir a tortura. In: SÃO Paulo (Estado). Procuradoria Geral do Estado. Grupo de Trabalho de Direitos Humanos. Direitos humanos: construção da liberdade e da igualdade. São Paulo: Centro de Estudos da Procuradoria Geral do Estado de São Paulo, 1998. p. 415-417.
} 
infligidos por um funcionário público ou outra pessoa no exercício de funções públicas, ou por sua instigação, ou com o consentimento ou aquiescência (...)".

Neste mesmo artigo, há a ressalva de que não se considerará tortura as dores e sofrimentos inerentes às sanções legítimas impostas aos condenados, ou consequência ou decorrência delas. Contudo, não pode o Estado, por meio das técnicas penitenciárias, gerar nos detentos sentimento de temor, angústia e de inferioridade além do que é decorrente da própria sanção, nem deve permitir a aplicação e execução de sanções demasiadamente $\operatorname{gravosas}^{25}$.

Em seguida, há a previsão de que a tortura deve ser reprimida por leis nacionais, com rigor, devendo os Estados signatários adotar medidas eficazes, tanto legislativas, quanto administrativas, judiciais ou de outra natureza, a fim de impedir a prática deste ato $\left(\operatorname{artigo} 2^{\circ}\right.$ ). Os Estados também não poderão proceder à expulsão, devolução ou extradição de uma pessoa para outro país quando houver risco de que a mesma seja lá submetida à tortura (artigo $\left.3^{\circ}\right)$.

Além das medidas acima, os Estados signatários desta convenção devem, conforme o artigo $4^{\circ}$, tipificar a tortura no ordenamento penal do país, assim como a tentativa de tortura, a cumplicidade e a participação neste crime ${ }^{26}$.

Os Estados devem assegurar que o ensino e a informação sobre a proibição da tortura sejam incorporados no treinamento de pessoal civil ou militar encarregado da aplicação da lei, e para quaisquer pessoas que participem da custódia, interrogatório ou tratamento de pessoas submetidas a qualquer forma de prisão, detenção ou reclusão, além de incluir tal proibição nas normas ou instruções relativas aos deveres e funções de tais pessoas, conforme o estabelecido no artigo 10.

\footnotetext{
$\overline{{ }^{25} \text { MARTOS NúÑEZ, }}$ 1991, p. 289-296.

${ }^{26}$ No Brasil, a principal legislação de combate à tortura é a Lei Federal n 9.455/97, que estabeleceu as condutas que constituem crime de tortura.
} 
As normas, instruções, métodos e práticas de interrogatório, custódia e tratamento de pessoas submetidas a qualquer forma de prisão, detenção ou reclusão devem estar sistematicamente sob exame, a fim de evitar qualquer caso de tortura (artigo 11); e, sempre que houver razões para crer que um ato de tortura tenha sido praticado, o Estado deve proceder a uma investigação imparcial dos fatos e à proteção dos autores de queixas e testemunhas de atos de tortura contra maus tratamentos e intimidação, conforme os artigos 12 e 13, da convenção.

Além de não poder invocar circunstâncias excepcionais como justificativa para a tortura, conforme determina o artigo $2^{\circ}$, o Estado deve desprezar declarações obtidas por meio deste ato, salvo se forem usadas em processos contra a pessoa acusada de tortura, a teor do artigo 15. Deve, ainda, interpretar os dispositivos desta convenção de modo a não restringir outros instrumentos internacionais ou legislações nacionais que proíbam penas ou tratamentos cruéis, desumanos ou degradantes, ou que se refiram à extradição ou à expulsão, ou, ainda, que contenham dispositivos de alcance mais amplo, conforme disciplina dos artigos $1^{\circ}$ e 16.2 .

Além da tortura, há, no artigo 16, a proibição de outros atos que constituam tratamentos ou penas cruéis, desumanos ou degradantes, que não caracterizam tortura como definida no artigo $1^{\circ}$, quando tais atos forem cometidos por funcionários públicos, ou pessoa no exercício de funções públicas, ou com sua instigação, consentimento ou aquiescência $^{27}$.

Também foi elaborado um protocolo facultativo para esta convenção, em 2002, para reforçar a proteção de pessoas privadas de liberdade quanto à submissão delas aos tratamentos e a penas cruéis, desumanas e degradantes, pois essas condutas são proibidas e constituem grave violação aos direitos humanos. Este protocolo considerou que o respeito completo dos direitos das pessoas é uma responsabilidade comum partilhada entre todos e que órgãos internacionais complementariam e reforçariam medidas nacionais para evitar essas práticas.

\footnotetext{
27 A tortura deve ser definida pela severidade da ação e não como um tratamento cruel com resultado agravado, pois é um ato que é cometido, deliberadamente, com o objetivo de infligir sofrimentos extremamente cruéis e severos em uma pessoa (STEINER, 2012, p. 316-319).
} 
Assim, criou-se um sistema preventivo de visitas regulares a centros de detenção, medida não judicial de natureza preventiva.

No primeiro artigo do protocolo, é estabelecido esse sistema de visitas regulares a centros de detenção por órgãos nacionais e internacionais independentes; e, em seguida, a criação de um Subcomitê de Proteção da Tortura e Outros Tratamentos ou Penas Cruéis, Desumanos ou Degradantes do Comitê contra a Tortura, que deverá desempenhar suas funções no marco das Nações Unidas ${ }^{28}$.

$\mathrm{O}$ artigo $3^{\circ}$, deste protocolo, prevê a criação de mecanismos preventivos nacionais, que deverão ser designados e mantidos pelos Estados signatários deste texto em nível doméstico, com independência funcional (artigo 18), cujas competências estão descritas no artigo 19 do documento ${ }^{29}$. O artigo $4^{\circ}$ estabelece que os Estados signatários devem permitir visitas do Subcomitê de Prevenção e dos mecanismos de proteção nacionais em qualquer estabelecimento onde pessoas são e podem ser privadas de sua liberdade, e garantir o acesso dos mecanismos preventivos nacionais às informações necessárias ao desenvolvimento de suas funções, conforme previsto no artigo 20, do protocolo.

As recomendações do mecanismo preventivo nacional devem ser examinadas e o Estado deve manter diálogo com o órgão sobre possíveis medidas para implementação, além da publicação e difusão dos relatórios anuais desse órgão, conforme artigos 22 e 23, do protocolo.

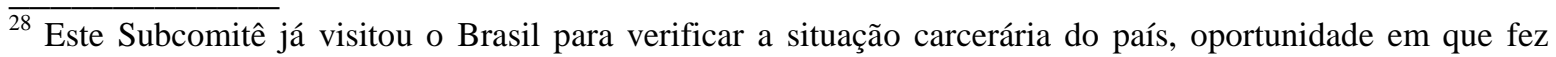
recomendações sobre os fatos constatados (ORGANIZAÇão DAS NAÇõES UNIDAS. Subcomitê de Prevenção da Tortura e outros Tratamentos ou Penas Cruéis, Desumanos ou Degradantes. Relatório sobre a visita ao Brasil do Subcomitê de Prevenção da Tortura e outros Tratamentos ou Penas Cruéis, Desumanos ou Degradantes CAT/OP/BRA/R.1,fevereiro de 2012. p. 9-10. Disponível em: <http://www.onu.org.br/img/2012/07/relatorio_SPT_2012.pdf〉, acesso em 17.08.2014).

${ }^{29}$ Os mecanismos preventivos nacionais têm, no mínimo, as seguintes competências: “a) examinar regularmente o tratamento de pessoas privadas de sua liberdade, em centro de detenção conforme a definição do artigo 4, da Convenção, com vistas a fortalecer, se necessário, sua proteção contra a tortura e outros tratamentos ou penas cruéis, desumanos ou degradantes; b) fazer recomendações às autoridades relevantes com o objetivo de melhorar o tratamento e as condições das pessoas privadas de liberdade e o de prevenir a tortura e outros tratamentos ou penas cruéis, desumanos ou degradantes, levando-se em consideração as normas relevantes das Nações Unidas; c) submeter propostas e observações a respeito da legislação existente ou em projeto".
} 
1.2. Conteúdo do princípio da humanidade

1.2.1 Dignidade da pessoa humana

Após a universalização dos direitos do homem, passou-se a reconhecer que toda pessoa é portadora de dignidade, qualidade intrínseca a ela, que não pode ser dela dissociada. É, também, a dignidade, irrenunciável e indisponível. Como consequência, a pessoa é reconhecida com valor em si mesma e possuidora de direitos fundamentais. Esses direitos garantem às pessoas a autodeterminação de suas vidas, sem indevidas ingerências do Estado, de modo que, constituindo, as pessoas, a finalidade precípua do ordenamento jurídico, não podem ser consideradas um mero meio ou objeto da atividade estatal.

No Brasil, a dignidade humana foi elevada à categoria de fundamento da República, pelo inciso III, do artigo $1^{\circ}$, da Constituição Federal de 1988.

Por não ser um direito clássico, não apareceu nas constituições mais antigas adotadas no século XVIII, como a dos Estados Unidos e a da França. A primeira vez que foi citada em uma constituição foi em 1919, na Constituição Alemã, em referência às condições de vida econômica. Depois, se seguiram as Constituições de Portugal (1933) e da Irlanda $(1937)^{30}$. Após a Segunda Guerra Mundial, a proteção à dignidade humana passou a ser mais intensa.

Este fundamento norteia o ordenamento jurídico e limita e orienta a ação estatal ${ }^{31}$, reconhecendo um núcleo indestrutível de prerrogativas às pessoas que o Estado Democrático não pode deixar de reconhecer e respeitar ${ }^{32}$.

Além de ser um dos fundamentos do Estado brasileiro, a dignidade da pessoa humana também é um princípio sistematizador, ao qual se baseiam os demais princípios

\footnotetext{
${ }^{30}$ VON MÜNCH, Ingo. La dignidad del hombre en el derecho constitucional alemán. Foro, Madri, n. 9, p. 108$109,2009$.

31 Machado Pelloni, Fernando M. Argumentos contra la tortura y los tratos crueles, inhumanos y degradantes. In: Fayet Jr, Ney; Maya, André Machado (Orgs.). Ciências penais: perspectivas e tendências da contemporaneidade. Curitiba: Juruá, 2011. p. 15-20.

32 SANTOS, Nivaldo dos; GARCIA, Thaís Aurélia. O tratamento constitucional da tortura e a violação da dignidade da pessoa humana. Revista da Faculdade de Direito da UFG, Goiânia, v. 32, n. 2, p. 75, jul./dez. 2008.
} 
constitucionais e que serve de parâmetro a todo o ordenamento jurídico, garantindo-lhe coerência interna. As leis devem refletir este princípio, podendo ser consideradas inconstitucionais as que o viola.

Desta forma, pode-se concluir que a dignidade humana delimita o poder de atuação do Estado, sendo o respeito a este princípio condição para a existência de um Estado Democrático e para a legitimidade do exercício do poder estatal, pois este deve respeitar e garantir a primazia dos direitos fundamentais, abstendo-se de práticas lesivas a estes.

Tendo em vista este direito, o Estado deve guiar suas ações para preservar a dignidade de cada pessoa e para criar condições que possibilitem o pleno desenvolvimento delas, além de tratar a todos igualitariamente e garantir para cada pessoa um direito individual protetivo em relação ao próprio Estado e aos demais indivíduos ${ }^{33}$.

A extensão dos direitos decorrentes da adoção da dignidade como fundamento da República pode ser extraída da própria Constituição Federal, que possibilita a todos os indivíduos o exercício do rol de direitos e garantias fundamentais por ela estabelecidos, que sintetiza as condições mínimas para o respeito do ser humano. Assim, é dever do Estado tomar as medidas necessárias para que todos os indivíduos exerçam plenamente seus direitos fundamentais trazidos pela Constituição, removendo os óbices a sua realização.

A Constituição de 1988 possui um texto extenso em matéria de direitos humanos fundamentais, como, por exemplo, o rol de direitos trazido pelo artigo $5^{\circ}$ e seus incisos, pois foi influenciada pelas duas décadas de regime autocrático, do qual o país acabara de sair, quando os direitos fundamentais foram suprimidos ${ }^{34}$.

Limitações ao exercício dos direitos fundamentais podem ser feitas excepcionalmente, a exemplo das sanções criminais, mas o Estado não pode, em razão das limitações realizadas, desprezar a dignidade inerente à pessoa, desrespeitando-a.

\footnotetext{
$\overline{{ }^{33} \text { SANTOS; GARCIA, }}$ 2008, p. 76-77.

${ }^{34}$ MACIEL, Adhemar Ferreira. Aspectos penais na Constituição. Revista Brasileira de Ciências Criminais, São Paulo, n. 13, p. 94, jan./mar. 1996.
} 
Em relação ao poder punitivo estatal, a dignidade humana também o limita, assim como fazem os demais princípios penais. Desta forma, as pessoas que cumprem penas criminais também devem ser reconhecidas e tratadas como possuidoras de direitos fundamentais, devendo a dignidade humana servir de garantia material para a realização desses direitos que elas possuem ${ }^{35}$. Ao ser condenada criminalmente, a pessoa, apesar de ter alguns direitos restringidos, não perde a sua dignidade.

Em razão da adoção da dignidade humana como fundamento do Estado, o homem deve ser tratado com valor em si mesmo, não podendo ser posto como mero objeto da justiça penal. Ao homem sempre deve ser dada a oportunidade de realizações e de liberdade, mesmo quando seus direitos estão restringidos em razão do cumprimento de determinada sanção penal ${ }^{36}$.

Essa limitação do poder punitivo estatal alcança tanto a qualidade quanto a quantidade de pena imposta às pessoas.

No Brasil, tem-se superadas as penas excessivamente aflitivas, como as que se encontravam no Livro V, das Ordenações Filipinas, que cominava, indiscriminadamente, a pena de morte, além de tratar como um objeto o condenado e diferenciar as penas segundo a classe social do autor e da vítima.

A dignidade humana permeia todo o ordenamento jurídico brasileiro, inclusive o sistema punitivo, e impõe respeito aos cidadãos e aos seus direitos. Este fundamento deve ser usado na criação, interpretação e aplicação do Direito Penal, de modo que nenhuma norma atente contra a dignidade dos condenados criminalmente ${ }^{37}$. É sobre o reconhecimento da dignidade humana que o Direito Penal deve se edificar ${ }^{38}$.

Devem ser garantidos a todos os indivíduos, inclusive os condenados

\footnotetext{
$\overline{35}$ SANTORO FILHO, Antonio Carlos. Fundamentos de direito penal: introdução crítica, aplicação da lei penal, teoria do delito. São Paulo: Malheiros, 2003. p. 43-46.

${ }^{36}$ DE LA CUESTA ARZAMENDI, José Luis. El principio de humanidad en derecho penal. Eguzkilore: Cuaderno del Instituto Vasco de Criminología, San Sebastian, n. 23, p. 210-211, 2009.

37 Del Monte, Thaís. Reflexos das novas formas de criminalidade nos princípios limitadores do poder punitivo estatal. Revista de Estudos Jurídicos UNESP, Franca, n. 23, p. 286-287, jan./jul. 2012.

${ }^{38}$ GUZMÁn DÁlborA, José Luis. Justicia penal y principio de humanidad. In: AVALOS RodríGUEZ, Constante Carlos; QuisPe VILlanueva, Alejandro Emilio (Coord.). Dogmática penal del tercer milenio: libro homenaje a los profesores Eugenio Raúl Zaffaroni y Klaus Tiedemann. Lima: Ara, 2008. p. 291.
} 
criminalmente, a satisfação de suas múltiplas necessidades básicas, inerentes do ser humano, o desenvolvimento de sua personalidade e o exercício dos direitos fundamentais constitucionais, excepcionando-se aqueles que, necessariamente, forem afetados com a imposição da sanção criminal ${ }^{39}$.

O Estado deve aplicar a pena criminal sem destruir o condenado ou sua personalidade, seja física, psíquica ou socialmente ${ }^{40}$.

Ainda em relação às consequências da adoção da dignidade humana como fundamento do Estado, a Constituição Federal, por meio do princípio da humanidade, proíbe a tortura, a pena cruel, e os tratamentos desumanos ou degradantes. A tortura, por exemplo, despoja a pessoa de sua condição de ser humano, pois the retira as faculdades de agir e de pensar livremente, sujeitando o indivíduo ao arbítrio do torturador. Não é possível ao Estado, por meio de seus agentes, adotar condutas que diminuam o indivíduo como pessoa, pois este é dotado de dignidade, que deve ser respeitada ${ }^{41}$.

Nota-se, desta forma, que, por causa da adoção da dignidade humana como fundamento do Estado, a pena imposta ao condenado deve garantir o exercício, ainda que não de forma plena, de seus direitos fundamentais, respeitando a pessoa em todos os seus aspectos.

\subsubsection{Princípio da humanidade}

O princípio da humanidade está diretamente interligado a um princípio geral de racionalidade que deriva da Constituição Federal, que exige, além da racionalidade da pena, uma vinculação entre o delito e sua consequência jurídica, razão pela qual o texto constitucional fez vedações, quando dispôs sobre os direitos e garantias fundamentais, quanto às penas e tratamento que não poderiam ser utilizados pela legislação penal brasileira $^{42}$.

\footnotetext{
$\overline{39}$ DE LA CUESTA ARZAMENDI, 2009, p. 210-211.

${ }^{40}$ GUZMÁN DÁLBORA, 2008, p. 292.

${ }^{41}$ SANTOS; GARCIA, 2008, p.78-81.

${ }^{42}$ ZafFAroni, Eugenio Raúl; PIERANGeli, José Henrique. Manual de direito penal brasileiro: parte geral. 8. ed. São Paulo: Revista dos Tribunais, 2009. p. 156-157. Nesse mesmo sentido, BATISTA afirma que o princípio
} 
O fundamento material deste princípio é a dignidade humana, que exerce a função de limite material à atividade punitiva do Estado. Desta forma, em razão deste princípio, a pena não pode ter por objetivo o sofrimento do condenado, nem o desconhecer enquanto pessoa portadora de dignidade.

Nessa matéria, a Constituição Federal dispôs de normas proibitivas para evitar um direito penal do terror, com sanções excessivamente aflitivas, e de normas asseguradoras de direitos aos presos e condenados criminalmente, com o objetivo de tornar as penas compatíveis com a condição humana ${ }^{43}$.

Historicamente, as penas têm propensão à gradativa humanização, tanto em seu tempo de duração, quanto em sua carga aflitiva.

Como já visto, a humanização das penas criminais está prevista em vários textos internacionais, tais como na Declaração Universal dos Direitos do Homem (1948), em seus artigos III e V; no Pacto Internacional dos Direitos Civis e Políticos (1966), em seu artigo $7^{\circ}$; e na Convenção contra a Tortura e outros Tratamentos ou Penas Cruéis, Desumanos ou Degradantes (1984), em seus artigos $1^{\circ}, 4^{\circ}$ e 16.

Na Constituição Federal Brasileira, este princípio pode ser extraído de diversos preceitos, como, por exemplo, no artigo $5^{\circ}$, incisos III (proibição da tortura e de tratamento desumano ou degradante), XLVII (proibição das penas de morte, salvo em caso de guerra declarada, de caráter perpétuo, de trabalhos forçados, de banimento e cruéis), XLIX (garantia de respeito à integridade física e moral dos presos) e L (condições para que as presas possam permanecer com seus filhos durante o período de amamentação). O princípio da humanidade também é encontrado em outros preceitos legais, como no artigo 40, da Lei de Execução Penal, e 38, do Código Penal, que garantem o respeito à integridade física e moral dos presos.

Necessário ressaltar que, conforme o artigo 60, inciso IV, $\S 4^{\circ}$, da Constituição

da humanidade postula uma sanção criminal racional e proporcional, que não desconhece o condenado como pessoa, e cujo objetivo não é afligir sofrimento ao condenado (BATISTA, Nilo. Introdução crítica ao Direito Penal Brasileiro. Rio de Janeiro: Revan, 2001. p. 98-101).

${ }^{43}$ Franco, Alberto Silva; LIRA, Rafael; Felix, Yuri. Crimes hediondos. 7. ed. São Paulo: Revista dos Tribunais, 2011. p. 81-83. 
Federal, esses direitos e garantias individuais são cláusulas pétreas e não podem ser objeto de deliberação a proposta de emenda tendente a aboli-los.

Essas normas podem ser separadas quanto a sua proposta negativa, que são aquelas que proíbem a tortura, tratamento cruel ou degradante, pena de morte, de caráter perpétuo, de trabalhos forçados, de banimento, penas cruéis; ou, quanto a sua proposta positiva, que asseguram o respeito à dignidade do preso ou condenado, garantindo, por exemplo, o respeito à integridade física e moral dos detentos, o cumprimento da pena em estabelecimentos distintos, em relação à natureza do delito, idade e sexo do apenado, condições para que presidiárias possam permanecer com seus filhos durante o período de amamentação $^{44}$.

Neste princípio se encontra, ainda, o fundamento da Política Criminal e a diretriz da execução penal e de humanização das penas criminais, como, por exemplo, o desuso das penas de morte e corporais para a utilização das penas privativas de liberdade e penas alternativas à privação de liberdade ${ }^{45}$. De acordo com o princípio da humanidade, a cominação, aplicação e execução das penas, especialmente a privativa de liberdade, devem coadunar com a dignidade humana, respeitando o indivíduo e abstendo-se de práticas desumanas e degradantes.

Além de proibir determinadas penas e prever normas de proteção aos condenados, especialmente os encarcerados, o princípio da humanidade dispõe que as sanções existentes devem ser executadas conforme a dignidade humana.

Assim, afeta o princípio da humanidade o modo de execução da pena, sobretudo da privativa de liberdade, se este mantiver os detentos em espaços não condizentes com a dignidade humana, como, por exemplo, em ambientes fétidos, sem higiene, sem o espaço físico e estrutura adequados para o número de presos, sem assistência médica.

Para atender ao princípio da humanidade das penas, deve haver uma redução do conteúdo aflitivo das sanções e compatibilizá-las, dentro do possível, com o máximo desfrute de direitos do condenado, cuja restrição não seja imprescindível para o

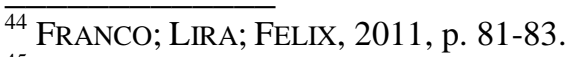

${ }^{45}$ FRANCO; LIRA; FELIX, 2011, loc. cit.
} 
cumprimento da pena ${ }^{46}$.

A pena criminal não pode ser meramente retributiva, nem uma coerção puramente negativa, como consequência de sua racionalidade, devendo, ainda, ter um sentido compatível com o ser humano e a dignidade a ele inerente. $\mathrm{O}$ caráter retributivo da pena deve ser o meio para se alcançar uma finalidade, e não o fim da sanção criminal ${ }^{47}$.

O ius puniendi do Estado, para ser legítimo, deve respeitar um conjunto de axiomas fundamentais, como os preceitos da necessidade, legalidade, imputação subjetiva e culpabilidade, além de seus correspondentes, como a subsidiariedade, intervenção mínima, caráter fragmentário do Direito Penal, taxatividade, responsabilidade pessoal e garantias penais básicas. Em sociedades democráticas, que têm por centro o valor da pessoa, todos esses preceitos devem ser respeitados, juntamente com o princípio da humanidade ${ }^{48}$. Este deve se projetar na extensão e intensão do Direito Penal ${ }^{49}$.

Além da diretiva dada aos legisladores, para não cominar penas proibidas constitucionalmente, este princípio também deve ser observado pelos juízes para que não o violem, na sentença, no momento da aplicação da pena, pois este princípio tem vigência absoluta. Uma pena que, em abstrato, não desrespeita o princípio da humanidade, pode o fazer no caso concreto, caso o juiz não atenda, por exemplo, a alguma característica do condenado, tal como portar uma enfermidade grave ${ }^{50}$.

Ressalta-se que, com a adoção deste princípio, não se pretende retirar por completo o caráter aflitivo das penas, pois retiraria o seu caráter retributivo; mas, sim, evitar as penas excessivamente aflitivas, que causam padecimento físico e moral além do que é inerente a própria sanção aplicada. As penas são manifestações da comunidade contra o delinquente, então não é possível esvaziá-las, retirando-lhe seu sentido retributivo e as consequências da retribuição, que são decorrentes da pena ${ }^{51}$.

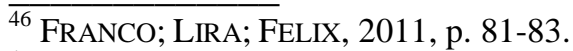

${ }^{47}$ BATISTA, N., 2001, p. 98-101.

${ }^{48}$ DE LA CUESTA ARZAMENDI, 2009, p. 209.

${ }^{49}$ GUZMÁN DÁlBORA, 2008, p. 292-293.

${ }^{50}$ ZAFFARONI; PIERANGELI, 2009, p. 156-157.

${ }^{51}$ DotTI, René Ariel. Bases e alternativas para o sistema de penas. São Paulo: Revista dos Tribunais, 1998. p 162-164. Nesse mesmo sentido, LUISI, 1991, p. 148-150.
} 
Desta forma, o princípio da humanidade norteia o ordenamento jurídico, tendo duas consequências práticas. A primeira se refere quanto às espécies de penas permitidas e proibidas no ordenamento jurídico, e o modo de execução delas. A outra consequência se refere às finalidades que se pretende obter através das sanções criminais.

Com este princípio, pretende-se, ainda, que todas as relações humanas existentes dentro do papel do Direito Penal descansem no princípio da humanidade, e que este princípio seja a base para novas relações que possam surgir dentro desse papel, como a solidariedade recíproca, a responsabilidade social com os reincidentes, e a ajuda, assistência social e vontade de recuperar os condenados ${ }^{52}$.

\subsubsection{Das penas vedadas}

\subsection{Pena de morte}

A abolição da pena de morte foi o marco inicial dos sistemas penais fundados no respeito à dignidade humana ${ }^{53}$.

No Brasil, a vedação desta pena se encontra no artigo 5, inciso XLVII, alínea "a", da Constituição Federal. Juntamente com esta proibição, há uma ressalva de que a pena de morte é admitida em caso de guerra declarada, conforme o artigo 84, inciso XIX, do texto constitucional $^{54}$.

A pena capital estava prevista no Código Criminal do Império, de 1830, que vigorou até 1890. Mas, a revogação de fato desta pena ocorreu ainda durante a vigência deste código, quando esta passou a ser desusada e, quando aplicada, comutada em pena de galés perpétua por Dom Pedro $\mathrm{II}^{55}$.

Durante a República, a única Constituição que não previu a proibição da pena de

\footnotetext{
52 JESCHECK, Hans-Heinrich. Tratado de derecho penal: parte general. 4. ed. Granada: Comares, 1993. p. 23. ${ }^{53}$ DOTTI, 1998, p. 159-161.

${ }^{54}$ De acordo com CERNICCHIARO, a pena de morte pode ser admitida em caso de guerra declarada, pois este evento põe em perigo a própria soberania do país, o que justificaria esta pena (CERNICCHIARO, Luiz Vicente. Princípio da individualização da pena. In: CERniCCHIARO, Luiz Vicente; COSTA JR, Paulo José da. Direito penal na Constituição. 3.ed. rev. e ampl. São Paulo: Revista dos Tribunais, 1995. p. 129-130).

${ }_{55}$ LUISI, 1991, p. 148-150.
} 
morte, ressalvado o caso de guerra declarada, foi a de 1937, apesar de o Código Penal de 1890 não mais prever essa pena. Todas as demais constituições proibiram a pena de morte.

No âmbito mundial, além dos textos internacionais que proíbem a pena de morte, em 1977, na Conferência Internacional sobre a Abolição da Pena de Morte, organizada pela Anistia Internacional, houve uma exortação para que os governos tomassem as medidas necessárias para abolir esta pena ${ }^{56}$.

O Estatuto de Roma, do Tribunal Penal Internacional, também não traz a pena de morte no rol de penas previstas para os crimes sob sua jurisdição, uma vez que esta pena não pode ser considerada compatível com um sistema centrado no respeito à pessoa humana.

Em um Estado respeitador da dignidade da pessoa não é possível admitir a previsão da pena de morte, pois é uma manifesta violação do direito à vida, e extermina o ser humano em sua essência, sem qualquer finalidade de prevenção especial ${ }^{57}$. A proibição desta pena não é apenas uma derivação da proibição de penas cruéis, desumanas e degradantes, pois estas não põem fim ao direito à vida como faz a pena de morte ${ }^{58}$.

Esta pena ultrapassa os limites de garantia que o Direito Penal deve assegurar num Estado Democrático de Direito ${ }^{59}$.

Sem qualquer finalidade preventiva, geral ou especial, a pena de morte, além de negar emenda ao réu, adquire um caráter irracional, meramente retributivo, que pode ser comparado à vingança e, portanto, injustificável e inútil ${ }^{60}$.

É uma pena que também pode se tornar cruel dependendo do seu modo de

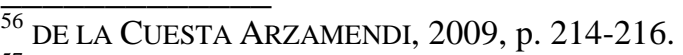

${ }^{57}$ SANTORO FILHO, 2003, p. 46-50. Conforme entendimento de COSTA JR., se a pena de morte exerce alguma função atemorizadora, a realiza sobre aqueles que não necessitam ser atemorizados, pois aqueles que cometem crimes não o deixam de fazê-lo em razão desta pena, pois contam com a possibilidade de não serem descobertos, ou de fuga, ou de recursos processuais para a não aplicação desta pena. Para o autor, esta pena só tem efeito negativo sobre o réu muito depois da sentença, quando lhe é negado o indulto e, efetivamente, o réu começa a esperar pela execução da pena (CosTA JR, Paulo José da. Da inutilidade da pena capital. In: Pena de morte. Coimbra: Faculdade de Direito da Universidade de Coimbra, 1967. v 2. p.108-109).

${ }^{58}$ DE LA CUESTA ARZAMENDI, op. cit., p. 214-216.

${ }^{59}$ LIMA, Carolina, 2009, p. 440-442.

${ }^{60}$ Costa JR, op. cit., p.105-109; e DOTTI, 1998, p. 159-161.
} 
execução, como, por exemplo, com a utilização da câmara de gás. A espera pela morte também pode se revelar excessivamente aflitiva para o condenado, que pode ficar meses ou anos à espera da execução da pena.

Outra característica negativa da pena de morte é a inadmissibilidade de reparação quanto a erros judiciais ${ }^{61}$, podendo por fim à vida de um inocente.

A pena de morte, ainda, se choca com o interesse público, entendido como um valor voltado para o respeito e consideração ao homem, do nascimento até sua morte ${ }^{62}$.

\subsection{Penas e tratamentos cruéis, desumanos e degradantes}

Outro corolário prático do princípio da humanidade é a proibição de tratamento de caráter cruel, desumano e degradante às pessoas que cumprem penas criminais, ou a adoção de penas com essas características, que têm por objetivo apenas causar sofrimento ou humilhação ${ }^{63}$. Ressalta-se que esta proibição não deve ser mera formalidade e que atos legais não podem legitimar penas com essas características.

A Constituição Federal Brasileira proíbe adoção de penas cruéis no inciso XLVII, alínea "e", de seu artigo $5^{\circ}$. A integridade física e moral dos presos é assegurada pelo inciso XLIX, deste mesmo artigo.

Por penas e tratamentos cruéis, desumanos e degradantes, entendem-se aqueles que submetem e infligem desnecessariamente padecimento físico ou moral ao condenado, atingindo sua dignidade, além do inerente à sanção aplicada ${ }^{64}$.

Em relação à diferença entre cruel, desumano e degradante, esses são atributos

\footnotetext{
${ }^{61}$ Um famoso caso de erro judicial na aplicação da pena de morte no Brasil foi a execução do fazendeiro Manoel Mota Coqueiro, em 1855, que foi condenado à morte pela prática de homicídio. Após sua execução, passou-se a discutir possível erro no julgamento do caso e há quem defenda que, por este motivo, esta foi a última pessoa executada no país (LUISI, 1991, p. 148-150; LIMA, Carolina, 2009, p. 444).

${ }^{62}$ CernicChiaro, 1995-a, p. 129-130.

${ }^{63}$ Pode ser considerado como antônimo de pena cruel, a pena racional, aquela que não desconsidera o homem como pessoa e cujo objetivo não é causar sofrimento no condenado (ZAFFARONI; PIERANGELI, 2009, p. 156157).

${ }^{64}$ Da mesma forma, caso o criminoso submeta a vítima, desnecessariamente, a tais tratamentos durante a perpetração de um crime, a conduta atrai maior reprovabilidade, conforme artigo 61, inciso II, alínea "d", do Código Penal (CERnicChIARO, op. cit., p. 141-143).
} 
graduados das penas que causam sofrimento físico e psíquico, que são sérios ataques à dignidade humana. A pena ou tratamento cruel é o que causa padecimento mais intenso e o degradante, o menos intenso.

A pena também tem esses atributos se há desproporção inusitada, exagerada e desnecessária entre o ilícito praticado e a sanção imposta, ou mediante a utilização de recursos incompatíveis com os foros de humanidade ${ }^{65}$.

Também não pode o Estado adotar penas que atentam contra a integridade física do condenado, deixando consequências permanentes, como, por exemplo, realizando amputações ou castração química em delinquentes sexuais.

O ordenamento jurídico não pode, ainda, adotar sanções ou meios de executá-la que impeçam a ressocialização do condenado, uma das finalidades da sanção criminal.

Para a prevenção dessas espécies de penas e tratamentos que são dispensados aos presos, além de ter o ordenamento jurídico penal coadunando com a dignidade humana e com este princípio, é necessária, também, a adoção de medidas que tornem esta proibição efetiva dentro dos estabelecimentos prisionais. Assim, por exemplo, visitas periódicas a prisões por diversas autoridades contribuem para a efetivação deste direito fundamental, como previsto no Protocolo Facultativo da Convenção contra a Tortura e Outros Tratamentos e Penas Cruéis, Desumanas ou Degradantes, adotado pela Assembleia Geral das Nações Unidas.

Deve haver esforço para evitar que as penas, que na legislação são compatíveis com o respeito à pessoa e a sua dignidade, não sejam, na prática, cruéis, desumanas ou degradantes, em razão das condições da infraestrutura para o cumprimento da pena e dos atos praticados pelos agentes estatais, sejam policiais ou agentes penitenciários ${ }^{66}$.

Ainda para a prevenção da ocorrência desses tratamentos, deve o Estado tipificar fatos tidos como tortura e demais tratamentos internacionalmente proibidos, conforme

\footnotetext{
$\overline{65}$ PRADE, Péricles. Limitação constitucional das penas cruéis. Cadernos de Direito Constitucional e Ciência Política, São Paulo, n. 16, p. 115-116, jul./set. 1996.

${ }^{66}$ Ibid., p. 117-118.
} 
dispõe a convenção citada acima. Essa proibição sempre deve ser tratada pela legislação dos países como absoluta, sem exceções por causas de justificação ${ }^{67}$.

\subsection{Prisão perpétua e penas de longa duração}

Outra consequência da adoção do princípio da humanidade pelo ordenamento jurídico é a proibição da prisão perpétua, vedada pelo artigo $5^{\circ}$, inciso XLVII, alínea "b", da Constituição Federal, e das penas de longa duração.

Conforme o artigo 10.1, do Pacto de Direitos Civis e Políticos, a prisão deve ser executada tendo em vista o princípio da humanidade e com respeito à dignidade das pessoas encarceradas, devendo este espaço respeitar a personalidade das pessoas e ser livre de tratamentos cruéis, desumanos e degradantes. Aplicando-se penas perpétuas ou de longa duração, ocorrem efeitos psicológicos e sociais negativos, retirando do detento toda a esperança de liberdade. É como uma espécie de tortura lenta, que causa sofrimento psicológico, incompatível com o princípio da humanidade ${ }^{68}$.

A prisão perpétua retira do indivíduo uma segunda chance na sociedade, tendo por objeto segregá-lo permanentemente. Ainda, não tendo qualquer objetivo ressocializador, a adoção dessa pena indica uma concepção retribucionista ${ }^{69}$.

A prisão perpétua também diverge do princípio da humanidade, pois retira da pena seu caráter proporcional, temporário e definido, não se compatibilizando com os preceitos de liberdade e respeito à dignidade humana ${ }^{70}$. Além disso, esta pena traz outros efeitos negativos, como, por exemplo, mantem a ociosidade do condenado, o que é inútil para a sociedade $^{71}$.

O Estatuto da Corte Penal Internacional faz uma ressalva quanto a esta pena, em seu artigo 77 , parágrafo $5^{\circ}$, dispondo que esta pena mais gravosa só deve ser aplicada quando se justifiquem a extrema gravidade do crime e as circunstâncias pessoais do

\footnotetext{
$\overline{67}$ DE LA CUESTA ARZAMENDI, 2009, p. 213.

${ }^{68}$ Ibid., p. 216-220.

${ }^{69}$ SANTORO FILHO, 2003, p. 46-50; DOTTI, 1998, p. 162-164.

${ }^{70}$ BATISTA, N., 2001, p. 98-101; DotTI, op. cit, p. 162-164; e LiMA, Carolina, 2009, p. 442-445.

${ }^{71}$ CERNICCHIARO, 1995-a, p. 130-132.
} 
condenado, devendo ser possível a revisão da sentença que condena à prisão perpétua após certo tempo de seu cumprimento ${ }^{72}$.

Desta forma, nos países que ainda adota-se esta pena, para que ela conserve certo vínculo com o princípio da humanidade, é necessário que o preso tenha uma expectativa concreta e realizável de uma eventual liberação, já que eliminar essa esperança do réu contraria o senso de humanidade. Portanto, a lei que regula a prisão perpétua deve trazer disposições sobre liberdade condicional após um prazo de efetivo cumprimento, suavizando a indeterminação da prisão perpétua e dando a necessária orientação ressocializadora da pena privativa de liberdade ${ }^{73}$.

As penas de longa duração também devem ser evitadas, uma vez que podem acabar se equiparando a uma pena perpétua ${ }^{74}$. Pena de longa duração, como, por exemplo, superior a 30 anos, dessocializa o condenado, podendo ser considerada um tratamento desumano e degradante ${ }^{75}$. Penas longas geram no detento desestímulo e revolta, fazendo com que ele perca a vontade de recomeçar a vida em liberdade ${ }^{76}$.

No Brasil, o limite de cumprimento da pena privativa de liberdade é de 30 anos, conforme o artigo 75, do Código Penal.

A duração das penas deve ser sempre revisada, reduzindo-a, se oportuno, como já aconteceu com o crime de homicídio, cuja pena cominada foi reduzida no atual Código Penal se comparado com o código de 1890, em que a pena máxima prevista para o homicídio simples era de 24 anos. A redução do tempo das sanções privativas de liberdade e a supressão das penas de curta duração também se fazem necessárias em razão do compromisso de proteção de direitos humanos, e tendo em vista que o encarceramento de curta ou média duração já podem trazer riscos de danos irreversíveis à personalidade do

\footnotetext{
$\overline{72}$ O Tribunal Constitucional Alemão se pronunciou no sentido de que esta pena é constitucional, desde que haja previsão legal de suspensão da execução da pena através de alguma forma de indulto, conforme artigo 57, do Código Penal Alemão, para que o condenado tenha alguma chance de liberdade (VON MüNCH, 2009, p. $118)$.

73 DE LA CUESTA ARZAMENDI, 2009, p. 213.

${ }^{74}$ Para que a pena não adquira caráter perpétuo, ela não pode ser excessivamente alta. Considerando o início da imputabilidade, aos 18 anos, o máximo cominado à sanção não pode impedir o condenado de recuperar a liberdade (CERNICCHIARO, 1995-a, p. 130-132).

${ }^{75}$ DE LA CUESTA ARZAMENDI, op. cit, p. 213.

${ }^{76}$ SANTORO FILHO, 2003, p. 46-50.
} 
preso $^{77}$.

A pena privativa de liberdade deve ter sua aplicação reduzida, até ter apenas um caráter residual, devendo os países que a adotam estabelecer um máximo em relação a sua duração, que deve ser sempre revisto ${ }^{78}$.

Considerando o rápido avanço científico e tecnológico, quanto mais tempo uma pessoa fica encarcerada, mais ela perde contato com o mundo exterior e com as suas mudanças e revoluções ${ }^{79}$.

\subsection{Pena de banimento e trabalhos forçados}

A pena de banimento está proscrita pelo artigo $5^{\circ}$, inciso XLVII, alínea “d”, da Constituição Federal. Ou seja, o ordenamento jurídico penal não pode prever pena que proíbe o indivíduo de permanecer em seu país de origem, perdendo o seu direito de nacionalidade, direito fundamental assegurado pelo artigo $5^{\circ}$, inciso LXXI, e artigo 12, da Constituição Federal.

A pena de trabalhos forçados está proibida na alínea "c", do artigo $5^{\circ}$, inciso XLVII, da Constituição Federal. Esta pena é desumana e degradante, pois retira do indivíduo a sua escolha, transformando-o em mero objeto da sociedade e do Estado, o que deixa a pena ainda mais aflitiva.

De acordo com o artigo 4.3, da Convenção Europeia de Direitos Humanos, artigo 8.3, alíneas "b" e "c", do Pacto Internacional de Direitos Civis e Políticos e artigo 6.2 e 6.3, alínea "a", da Convenção Americana de Direitos Humanos, o trabalho pode ser exigido do preso, sem que se constitua uma pena desumana ou degradante, desde que respeitados os requisitos trazidos por essas convenções, tais como que seja imposta por

\footnotetext{
$\overline{77}$ DOTTI, 1998, p. 162-164.

${ }^{78}$ RivaCOBA Y RIVACOBA Manuel de. Tentaciones, principios y perspectivas para una política criminal en Chile a la altura de los tiempos. In: LuISI, Luiz (et al). Politica criminal y reforma penal. Santiago: Jurídica ConoSur, 1996. p. 36.

${ }^{79}$ DoTTI, op. cit., p. 162-164.
} 
tribunal competente, que não afete a dignidade nem a capacidade física ou intelectual do condenado.

No Brasil, o trabalho gratuito do preso está superado, devendo esta atividade atender ao artigo 28, da Lei de Execução Penal. Necessário ressaltar que a prestação de serviços à comunidade, medida alternativa à prisão, prevista no artigo $5^{\circ}$, incido XLVI, alínea "d", do texto constitucional, não é desumana e não se confunde com trabalhos forçados, pois sua pretensão é não privar o indivíduo da liberdade, evitando os prejuízos do encarceramento de curta duração e substituindo a prisão por uma atividade que não prejudique a dignidade do condenado, nem que seja a ele vexatória ou humilhante ${ }^{80}$. Esta pena também não prejudica a vida normal do condenado e traz resultados positivos para a sociedade ${ }^{81}$.

Ainda, a prestação de serviços à comunidade restringe um direito do condenado e, além de sua finalidade retributiva, tem por objetivo gerar um senso de responsabilidade para desestimulá-lo a retornar à criminalidade. E, para que esta alternativa à prisão não seja vazia de conteúdo, é necessário ajustá-la à natureza da infração cometida ${ }^{82}$.

\subsubsection{Da finalidade da pena}

Além da vedação de determinadas espécies de penas, o princípio da humanidade estabelece que as penas criminais devam ter uma orientação ressocializadora, especialmente a pena privativa de liberdade, conforme artigo 10.3, do Pacto Internacional de Direitos Civis e Políticos, e artigo 5.6, da Convenção Americana de Direitos

\footnotetext{
${ }^{80}$ Esta é uma pena restritiva de direitos, que é autônoma e substitui a pena privativa de liberdade quando preenchidos os requisitos do artigo 44, do Código Penal. A prestação de serviço à comunidade ou a entidade pública está regulada no artigo 46, do Código Penal, onde estipula que está só é aplicável como substituição às condenações superiores a seis meses de privação de liberdade. Ainda, conforme este dispositivo, consiste na atribuição de tarefas gratuitas ao condenado, dando-se a prestação de serviços em entidades assistenciais, hospitais, escolas, orfanatos e outros estabelecimentos congêneres, em programas comunitários ou estatais. As tarefas desta prestação devem ser atribuídas conforme as aptidões do condenado, devendo ser cumpridas à razão de uma hora de tarefa por dia de condenação, fixadas de modo a não prejudicar a jornada normal de trabalho. Mas, se a pena substituída for superior a um ano, é facultado ao condenado cumprir a pena substitutiva em menor tempo, nunca inferior à metade da pena privativa de liberdade fixada.

${ }^{81}$ SANTORO FILHO, 2003, p. 46-50.

${ }^{82}$ CernicChiaro, 1995-a, p. 137-138.
} 
Humanos $^{83}$.

Assim, para que a pena possa alcançar esta finalidade, deve-se orientar o cumprimento da pena privativa de liberdade para reduzir o conteúdo estigmatizador da prisão e a execução da pena deve, também, ser no sentido da superação da marginalização ${ }^{84}$.

É em razão, também, deste caráter ressocializador, que deve ser abolida a pena de morte e demais penas que criem um impedimento físico permanente no condenado, como a castração química de delinquentes sexuais, amputações, esterilização ${ }^{85}$. Não é possível, ainda tendo em vista essa finalidade da pena, a adoção de sanções perpétuas, nem outras que mantem o indivíduo à margem da sociedade, impedindo-o de se integrar a ela.

Contudo, em razão do respeito à dignidade dos condenados, e, ainda, atentando-se ao princípio da humanidade, deve-se ter cuidado com a ressocialização forçada do condenado $^{86}$.

O objetivo de ressocializar o condenado não deve ser coativo, nem entendido como uma manipulação legal dos valores do sujeito. O Estado, para alcançar esta finalidade, deve apresentar uma oferta de alternativas ao preso, e, quando necessário, oferecer tratamento individual àqueles que necessitarem ${ }^{87}$.

A prisão deve estimular o exercício de direitos não atingidos pela condenação, atenuando os efeitos do afastamento do detento da sociedade e possibilitando a promoção de um processo de gradual reintegração social, motivo pelo qual é também importante a adoção de um sistema progressivo de cumprimento de pena. Dentro da prisão, devem ser adotados os procedimentos prisionais que reduzam significativamente o perigo da dessocialização ${ }^{88}$.

\footnotetext{
$\overline{83}$ DE LA CUESTA ARZAMENDI, 2009, p. 210-211.

${ }^{84}$ Ibid., p. 222-223.

${ }^{85}$ JESCHECK, 1993, p. 23; ZAFFARONI; PIERANGELI, 2009, p. 156-157.

${ }^{86}$ FRANCO; LIRA; FELIX, 2011, p. 81-83.

${ }^{87}$ MARTOS NÚÑEZ, 1991, p. 289-296.

${ }^{88}$ FRANCO; LIRA; FELIX, op. cit, p. 81-83.
} 
Aos presos, devem ser reconhecidos seus direitos constitucionais fundamentais, não podendo o Estado permitir que as prisões se transformem em um simples depósito de pessoas. Desta forma, ações para o controle da superpopulação carcerária devem ser tomadas aplicando-se, por exemplo, penas substitutivas à privação de liberdade, para evitar o encarceramento de curta duração.

Podem ser tomadas, ainda, medidas assistenciais que devem acompanhar o tratamento criminal em liberdade, para que o condenado se reincorpore à sociedade, evitando a manutenção da marginalização. Contudo, tais medidas devem ser tomadas dentro da função do Direito Penal, de responsabilizar o autor pela infração criminal, senão, do contrário, o Direito Penal torna-se um direito de recompensa ${ }^{89}$.

Mas, não basta apenas a elaboração de legislação sobre esse tema, devendo essas medidas ser efetivamente implantadas. A pena de prestação de serviços à comunidade, por exemplo, para ser um trabalho social com conteúdo positivo, deve ter uma boa infraestrutura estatal para funcionar ${ }^{90}$.

\subsubsection{Outras incidências do princípio da humanidade}

O princípio da humanidade também incide sobre outras esferas do Direito Penal e do Direito Processual Penal.

O perdão judicial e a possibilidade de prisão domiciliar em caso de doença são exemplos de decorrências do princípio da humanidade ${ }^{91}$.

Pode ser considerado um dos corolários do princípio da humanidade a atenção que deve ser dada às vítimas de todas as infrações criminais, pois não pode o Direito Penal ignorar as necessidades delas.

As vítimas têm direito à informação e à verdade, ao acesso à Justiça e à reparação, devendo ser esta reparação integral; ou seja, assistência, acompanhamento e ajuda do

\footnotetext{
${ }^{89}$ JESCHECK, 1993, p. 23.

90 DE LA CUESTA ARZAMENDI, 2009, p. 222-223.

${ }^{91}$ ZAFFARONI, Eugenio Raúl; et al. Direito penal brasileiro: primeiro volume - teoria geral do direito penal. $3^{\mathrm{a}}$ ed. Rio de Janeiro: Revan, 2006. p. 233-234.
} 
Estado para superar a vitimização. Também têm direito a reabilitar-se e reinserir-se na sociedade. Para isso, o Direito Penal pode, por exemplo, oferecer tratamento especial a fim de manter certa distância entre acusado e vítima, ou até abrir espaço para a vítima no âmbito da execução das penas ${ }^{92}$.

$\mathrm{O}$ ordenamento jurídico traz algumas previsões que demonstram uma maior preocupação com a vítima no processo de apuração de uma infração criminal, como, por exemplo, a necessidade de reparação do dano para obtenção do livramento condicional, salvo impossibilidade de fazê-lo, a reparação do dano como efeito da condenação, prevista no artigo 91, inciso I, do Código Penal, a necessidade de reparação do dano como condição da suspensão condicional do processo, salvo impossibilidade de fazê-lo, prevista na Lei Federal $n^{\circ}$ 9.099/1995, que traz como um de seus objetivos a reparação dos danos sofridos pela vítima, e a multa reparatória, prevista no artigo 297, do Código de Trânsito Brasileiro $^{93}$.

Como será visto adiante, há, também, outras soluções que humanizam o Direito Penal, dando mais atenção às vítimas da infração criminal, como a prestação pecuniária, prevista no Código Penal, e a medida socioeducativa de reparação do dano, prevista no Estatuto da Criança e do Adolescente. Estas duas consequências jurídicas para a infração praticada têm o condão de restaurar o prejuízo da vítima, não a deixando suportar os prejuízos do crime sozinha ${ }^{94}$.

Contudo, necessário salientar que alguns desses dispositivos ainda encontram dificuldade de ser efetivados, como a reparação do dano como efeito da condenação, ainda mais quando se trata de vítimas pobres. Ademais, distanciando-se do tratamento da vítima com humanidade, o Código Penal ainda traz o comportamento da vítima como uma das circunstâncias para a fixação da pena, no artigo 59, sendo que, neste caso, este elemento

\footnotetext{
92 DE LA CUESTA ARZAMENDI, 2009, p. 224-225.

93 BITENCOURT, Cezar Roberto. Novas penas alternativas: análise político-criminal das alterações da lei $\mathrm{n}$. 9.714/98. São Paulo: Saraiva, 1999. p. 20-29.

94 DotTI, René Ariel. O Sistema geral das penas. In: DotTi, René Ariel; ReAle JR., Miguel; Toledo, Francisco de Assis; SHECAIRA; Sergio Salomão; AzEVEdo; David Teixeira de; LoPES, Mauricio Antonio Ribeiro. (Orgs.). Penas restritivas de direitos: Críticas e comentários às penas alternativas. São Paulo: Revista dos Tribunais, 1999. p. 107-108. Nesse mesmo sentido, SHECAIRA; Sergio Salomão. Penas alternativas. In: DotTI, René Ariel; Reale JR., Miguel; Toledo, Francisco de Assis; Shecaira; Sergio Salomão; AZEVEDo; David Teixeira de; LOPES, Mauricio Antonio Ribeiro. (Orgs.). Penas restritivas de direitos: Críticas e comentários às penas alternativas. São Paulo: Revista dos Tribunais, 1999. p. 228-229.
} 
acaba funcionando como um fator criminógeno, diminuindo a censurabilidade da infração praticada $^{95}$. 


\section{CAPÍTULO 2. PENA PRIVATIVA DE LIBERDADE}

\subsection{A pena privativa de liberdade no Brasil}

Prevista no artigo 50, inciso XLVI, alínea "a", da Constituição Federal, a pena privativa de liberdade é uma das sanções que o legislador ordinário pode cominar aos crimes e está posta na mesma alínea que a restrição da liberdade, uma alternativa à privação total deste direito. Contudo, no Código Penal, encontra-se apenas a privação de liberdade como pena principal, havendo a previsão de penas restritivas de liberdade apenas no que tange às penas restritivas de direitos, que substituem as penas privativas de liberdade, como, por exemplo, a pena de limitação de final de semana ${ }^{96}$.

Esta privação ou restrição de liberdade, que se refere a Constituição, na previsão de penas criminais, é a liberdade de locomoção, mantendo o condenado todos os seus outros direitos em relação à liberdade, tais como a liberdade de pensamento, de reunião, de profissão, de ação, de culto religioso. Há, a esses direitos, apenas a restrição necessária em decorrência da privação da liberdade de locomoção, conforme artigo 38, do Código Penal.

Há dois tipos de pena privativa de liberdade, previstas em nosso ordenamento: a reclusão e a detenção, embora não exista diferença essencial entre elas ${ }^{97}$. No geral, a reclusão é cominada para os delitos mais graves, enquanto a detenção, para os menos graves.

Das diferenças remanescentes entre as duas formas de privação de liberdade, podemos citar, por exemplo: o regime inicial de cumprimento de pena, que para a reclusão é o fechado, semiaberto e aberto, enquanto que na detenção o regime inicial é o semiaberto e o aberto, salvo necessidade de transferência ao regime fechado, conforme artigo 33, do

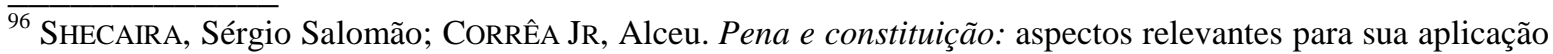
e execução. São Paulo: Revista dos Tribunais, 1995. p. 187-188.

${ }^{97}$ DOTTI, 1998, p. 361.
} 
Código Penal; a reclusão é cumprida anteriormente à detenção em casos de concurso material, conforme artigo 69, do Código Penal; para a aplicação de medida de segurança, se se tratar de crime que prevê reclusão, esta será detentiva, enquanto que se prevista a detenção, poderá ser ambulatorial, conforme o artigo 97, do mesmo código; e nos crimes cometidos contra filhos, tutelados e curatelados, que preveem reclusão como sanção, pode haver a perda de pátrio poder, tutela ou curatela, conforme o artigo 92, inciso II, do Código Penal.

Ainda em relação à pena privativa de liberdade, necessário ressaltar que, de acordo com o regime de cumprimento da pena (artigos 33 a 36, do Código Penal), a privação total da liberdade ocorre apenas nos dois primeiros regimes, fechado e semiaberto. No último regime de cumprimento da pena privativa de liberdade, o aberto, o que ocorre, na verdade, é uma restrição da liberdade, em decorrência da mera supervisão da liberdade de locomoção do condenado ${ }^{98}$.

Além de permitir a cominação desta pena no ordenamento jurídico penal, o texto constitucional também estabelece outros direitos que a lei deve garantir aos condenados ao dispor sobre a pena privativa de liberdade, como, por exemplo, que ninguém deve ser submetido a tortura, nem a tratamento desumano ou degradante, conforme seu artigo $5^{\circ}$, inciso III.

Nesse mesmo artigo, dispôs sobre outros direitos que também devem ser assegurados às pessoas que cumprem pena privativa de liberdade, como, por exemplo, que é garantida, nos termos da lei, a prestação de assistência religiosa nas entidades civis e militares, de internação coletiva, no inciso VII, que a pena não pode passar da pessoa do condenado, no inciso XLV, e que a privação de liberdade não pode se caracterizar pena de caráter perpétuo, de trabalhos forçados ou cruéis, conforme inciso XLVII, alíneas "b", "c" e "e".

Em relação especificamente a esta pena, a Constituição Federal determina que ela seja cumprida em estabelecimentos distintos, de acordo com a natureza do delito, a idade e

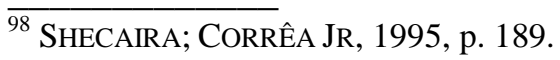


o sexo do apenado, conforme o inciso XLVIII, do artigo $5^{\circ}$, que seja assegurado ao preso o respeito por sua integridade física e moral, de acordo com o inciso XLIX, desse mesmo artigo, e, como determina o inciso L, às presidiárias devem ser asseguradas condições para que possam permanecer com seus filhos durante o período de amamentação ${ }^{99}$.

Já no Código Penal, a pena privativa de liberdade está prevista no artigo 32, inciso I, e é regulada entre os artigos 33 e 42.

O juiz, atendendo aos requisitos do artigo 59, do Código Penal, tais como culpabilidade, antecedentes, conduta social, personalidade do agente, motivos, circunstâncias e consequências do crime, bem como ao comportamento da vítima, se estabelecer a pena privativa de liberdade como aquela a que o réu será condenado, deverá, também, fixar a quantidade de pena a ser cumprida, dentro dos limites previstos para a sanção, o regime inicial de cumprimento de pena, e, se cabível, a substituição da pena privativa de liberdade por outra espécie de pena.

No Brasil, o tempo de cumprimento máximo das penas privativas de liberdade não pode exceder a 30 (trinta) anos, conforme o artigo 75, do Código Penal. Se o agente for condenado a pena privativa de liberdade superior a este montante ou a penas cuja soma exceda a 30 (trinta) anos, elas devem ser unificadas pelo juízo da execução para atender ao limite máximo citado acima ${ }^{100}$. Em caso de sobrevir condenação por fato posterior ao início do cumprimento da pena, deverá ser feita nova unificação, desprezando-se, para esse fim, o período de pena já cumprido, de acordo com os parágrafos do artigo citado acima.

2.1.1. Dos regimes de cumprimento de pena privativa de liberdade

O Código Penal estabelece, em seu artigo 33, que as penas privativas de liberdade devem ser cumpridas em três regimes: fechado, semiaberto ou aberto.

\footnotetext{
$\overline{99}$ Em relação às mulheres, o artigo 37, do Código Penal, complementa o texto constitucional, estabelecendo que elas devem cumprir pena em estabelecimento próprio, observados os deveres e direitos inerentes a sua condição pessoal.

100 Aqueles que cumpriram prisão provisória, no Brasil ou no estrangeiro, ou prisão administrativa, terão o tempo dessas detenções computado na pena privativa de liberdade, conforme artigo 42, do Código Penal e artigo 387, $\S 2^{\circ}$, do Código de Processo Penal.
} 
Esses regimes serão cumpridos de maneira progressiva, de modo a permitir que o condenado recupere a liberdade e volte ao convívio social aos poucos, por meio de etapas. Do contrário, sem a possibilidade de progressão, o condenado se dessocializa, eliminando da pena qualquer objetivo ressocializador e conferindo a ela caráter meramente retributivo $^{101}$. Conforme o artigo 5.6, da Convenção Americana de Direitos Humanos, a finalidade da pena é a reforma e a readaptação social do condenado, ou seja, a pena deve ser executada de modo a adaptar o condenado para seu retorno ao convívio na sociedade e ensejar a convivência social ${ }^{102}$.

Por isso que a pena deve permitir que o condenado retorne à sociedade aos poucos, pois a possibilidade de progressão de regime de cumprimento de pena privativa de liberdade estimula o comportamento socialmente adequado no condenado e gera nele a esperança de saída com previsibilidade ${ }^{103}$.

Ademais, a fixação do regime inicial de cumprimento de pena privativa de liberdade e a possibilidade de progressão de regime concretizam o princípio da individualização da pena ${ }^{104}$.

No entanto, a viabilidade desse sistema exige a construção de estabelecimentos penais adequados a cada regime, sem os quais se compromete a execução progressista da pena privativa de liberdade.

No sistema penal brasileiro, o juiz da instrução, na sentença condenatória, determina o regime inicial de cumprimento da pena, ficando a cargo do juiz da execução a progressão e a regressão de regime.

\footnotetext{
${ }^{101}$ FRANCO; LIRA; FELIX, 2011, p. 81-83.

102 CERNICCHIARO, Luiz Vicente. Pena: cumprimento integral em regime fechado. In: Escritos em homenagem a Alberto Silva Franco. São Paulo: Revista dos Tribunais, 2003. p. 291-292.

${ }^{103}$ SYDOw, Spencer Toth. Retratos do regime semiaberto. Revista Magister de Direito Penal e Processual Penal, Porto Alegre, v. 10, n. 56, p. 108, out./nov. 2013.

${ }^{104}$ KARAM, Maria Lúcia. Regimes de cumprimento da pena privativa de liberdade e supremacia da ordem constitucional. In: Escritos em homenagem a Alberto Silva Franco. São Paulo: Revista dos Tribunais, 2003. p. 312-313.
} 
Além de dispor sobre o sistema progressivo de cumprimento de pena, o artigo 33, $\S 2^{\circ}$, do Código Penal, estabelece que a progressão deve ocorrer, também, segundo o mérito do condenado ${ }^{105}$. Determina, ainda, que o regime inicial deve ser fixado observando que o condenado à pena privativa de liberdade superior a 8 (oito) deverá cumpri-la inicialmente em regime fechado; o condenado não reincidente à pena superior a 4 (quatro) anos e que não exceda a 8 (oito) anos, poderá, desde o princípio, cumpri-la em regime semiaberto; e o condenado à pena igual ou inferior a 4 (quatro) anos, poderá cumpri-la, desde o início, em regime aberto.

Conforme o artigo 33, parágrafos $2^{\circ}$ e $3^{\circ}$, do Código Penal, além de observados esses critérios citados acima, para a definição do regime inicial de cumprimento de pena, devem ser observadas as hipóteses de transferência ao regime mais rigoroso, como os critérios previstos no artigo 59, do mesmo código, tais como culpabilidade, antecedentes, conduta social, personalidade do agente, motivos, circunstâncias e consequências do crime $^{106}$.

Em caso de haver condenação por mais de um crime, no mesmo processo ou em processos distintos, a determinação do regime inicial de cumprimento de pena deve ser feita pelo resultado da soma ou unificação das penas, observada, se for o caso, a detração ou remição, conforme artigo 111, da Lei de Execução Penal. Sobrevindo condenação no curso da execução, somar-se-á a pena ao restante da que está sendo cumprida, para determinação do regime.

O parágrafo primeiro, do artigo 33, do Código Penal dispõe que as penas a serem cumpridas em regime fechado devem ser executadas em estabelecimento de segurança máxima ou média, as que devem ser cumpridas em regime semiaberto, em colônia

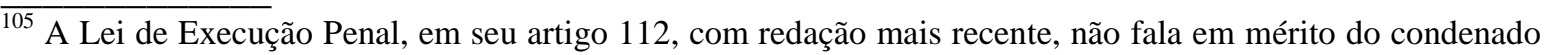
para fins de progressão de regime, e sim em bom comportamento carcerário, comprovado pelo diretor do estabelecimento. Enquanto a lei falava em mérito para a progressão de pena, além de o indivíduo ter que ostentar bom comportamento carcerário, também deveria demonstrar aptidão para adaptar-se a regime menos rigoroso (GIACOMUZZI, Vladimir. Sistema progressivo de cumprimento da pena privativa de liberdade. In: FAYET JR, Ney; WedY, Miguel Tedesco (Org.). Estudos críticos de direito e processo penal: em homenagem ao Des. Garibaldi Almeida Wedy. Porto Alegre: Livraria do Advogado, 2004. p. 217-218).

106 Conforme o enunciado 719, da súmula do Supremo Tribunal Federal, "A imposição do regime de cumprimento mais severo do que a pena aplica permitir exige motivação idônea".
} 
agrícola, industrial ou estabelecimento similar, e em regime aberto, em casa de albergado ou outro estabelecimento adequado.

O regime fechado é descrito no artigo 34, do Código Penal, que estabelece que o condenado a este regime seja, no início do cumprimento da pena, submetido a exame criminológico de classificação para individualização da execução da pena. O condenado ficará sujeito a trabalho comum dentro do estabelecimento, na conformidade de suas aptidões ou ocupações anteriores, desde que compatíveis com a execução da pena, e ficará isolado durante o período noturno.

No regime fechado, o trabalho externo é admissível, em serviços ou obras públicas, conforme dispõe o artigo $34, \S 3^{\circ}$, do Código Penal.

O condenado ao regime semiaberto ficará sujeito a trabalho comum durante o período diurno, em colônia agrícola, industrial ${ }^{107}$ ou estabelecimento similar. Neste caso, o trabalho externo também é admissível, bem como a frequência em cursos supletivos profissionalizantes, de instrução de segundo grau ou superior.

Ao contrário do regime fechado, em que o ambiente é de maior restrição da liberdade de locomoção e maior cautela contra fugas, no regime semiaberto essas circunstâncias se reduzem ${ }^{108}$, havendo, por exemplo, as possibilidades de saída do cárcere previstas no artigo 122, da Lei de Execução Penal.

Por fim, no regime aberto, a pena baseia-se na autodisciplina e senso de responsabilidade do condenado, conforme enuncia o artigo 36, do Código Penal.

\footnotetext{
$\overline{107}$ A lei, ao prever somente as colônias agrícolas e industriais para o cumprimento da pena em regime semiaberto, não insere o condenado no setor de serviços da economia, fazendo com que ele receba, nestes estabelecimentos, apenas conhecimentos de ofícios de pequena procura no mercado de trabalho moderno. Assim, a ideia de utilizar o trabalho como ferramenta para reintegrar o condenado na sociedade não se efetiva com as possibilidades dadas pela lei (SYDOW, 2013, p. 108).

${ }^{108}$ MuAKAD, Irene Batista. Pena privativa de liberdade. São Paulo: Atlas, 1996. p. 61-67.
} 
No regime aberto, restrições de liberdade de locomoção praticamente não existem, pois é necessário despertar no condenado sentimento de responsabilidade pessoal, traduzida em autodomínio e sincronização com a sociedade ${ }^{109}$.

Neste regime, o condenado deve, fora do estabelecimento e sem vigilância, trabalhar, frequentar curso ou exercer outra atividade autorizada, permanecendo recolhido durante o período noturno e nos dias de folga nas casas de albergado ${ }^{110}$.

2.1.1.1. Da progressão e da regressão de regime

Como visto, a pena privativa de liberdade deve ser cumprida de modo progressivo, passando, o condenado, a regime menos severo quando cumpridos os requisitos legais.

A pena deve ser cumprida de modo progressivo para que a pena privativa de liberdade atenda a sua função de reinserção social do condenado. Assim, cada etapa da progressão da pena é importante para a execução descontínua da privação da liberdade ${ }^{111}$. A cada etapa da progressão, o condenado vê-se recuperar um pouco de sua liberdade até, ao fim da pena, não se encontrar mais privado deste direito, retornando definitivamente ao convívio social.

Contudo, ferindo o princípio constitucional da individualização da pena e inviabilizando a sua função ressocializadora, a Lei Federal $n^{\circ}$ 8.072/1990 tentou estabeleceu em seu artigo $2^{\circ}, \S 1^{\circ}$, a vedação da progressão de regime para aqueles condenados por crimes hediondos, devendo estes cumprir a pena integralmente em regime fechado. Em 2006, o Supremo Tribunal Federal, ao julgar o HC nº 82.959, declarou que tal dispositivo era inconstitucional, e que os condenados por crimes hediondos também tinham

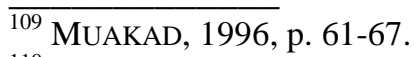

${ }^{110} \mathrm{Na}$ prática, em razão da falta de estrutura do Estado para o cumprimento das penas privativas de liberdade impostas, os condenados em regime aberto cumprem a pena em prisão domiciliar, mesmo não se enquadrando nas hipóteses do artigo 117, da Lei de Execução Penal, pois são escassas as casas de albergado no país (SHECAIRA, Sérgio Salomão; CORRÊA JR., Alceu. Teoria da pena: finalidades, direito positivo, jurisprudência e outros estudos de ciência criminal. São Paulo: Revista dos Tribunais, 2002. p. 313-315).

${ }^{111}$ SÃo Paulo (Estado). Procuradoria Geral do Estado. Grupo PENAl do SERViço de Apoio Jurírico; SOARES, Flávia D'Urso Rocha (relat.). O sistema progressivo de cumprimento da pena e a ofensa às garantias constitucionais (jurisprudência comentada). Revista Brasileira de Ciências Criminais, São Paulo, v. 1, n. 4, p. 154, out./dez. 1993.
} 
direito à progressão de regime ${ }^{112}$. No ano seguinte, com a edição da Lei Federal $\mathrm{n}^{\mathrm{o}}$ 11.464/2007, os legisladores possibilitaram a progressão de regime aos condenados por crimes hediondos, desde que cumprissem $2 / 5$ da pena, em casos de réu primário, e 3/5, em caso de reincidentes ${ }^{113}$.

Além de inviabilizar a individualização, o cumprimento da pena em regime integralmente fechado afronta a finalidade da pena, pois o regime progressista é fundamental na readaptação social do condenado ${ }^{114}$. A pena, nestes casos, por impedir um tratamento penitenciário racional e progressivo também é desumana, deixando o recluso sem esperança de obter liberdade antes do fim da pena ${ }^{115}$.

Além da aflição física, a prisão submete o indivíduo a um prolongado trauma psicológico, sensorial e afetivo, que traz consequências psíquicas e emocionais ${ }^{116}$. Assim, quanto mais tempo o condenado ficar dentro do cárcere, sobretudo no regime fechado, maiores serão as consequências negativas, e mais difícil será reintegrá-lo à convivência social.

\footnotetext{
${ }^{112}$ MOURA, Maria Thereza Rocha de Assis. O IBCCRIM e a inconstitucionalidade da proibição de progressão nos crimes hediondos. Boletim IBCCRIM, São Paulo, v. 20, n. 237 - Edição Especial, p.6-7, ago. 2012.

${ }^{113}$ Nestes casos, conforme o Enunciado $\mathrm{n}^{\circ} 26$, da Súmula Vinculante do Supremo Tribunal Federal, o magistrado pode determinar, de modo fundamentado, a realização de exame criminológico para avaliar se o condenado preenche os requisitos objetivos e subjetivos para a progressão de regime.

114 CernicChiaro, 2003, p. 289-292. Para KARAM, o regime inicial fechado obrigatório, previsto na Lei Federal $\mathrm{n}^{\circ}$ 9.455/1997 (lei que define os crimes de tortura), em seu artigo $1^{\circ}$, parágrafo $7^{\circ}$, também viola o princípio da individualização da pena e dá um tratamento mais rigoroso para esses crimes de maior danosidade social além do previsto pela Constituição Federal, que referiu-se apenas à impossibilidade de fiança, graça e anistia. Desta forma, diante da violação da individualização da pena, a dignidade da pessoa é negada. $\mathrm{O}$ mesmo acontece nos casos de reincidência, em que o regime inicial deve ser o fechado. Nestes casos, há uma maior severidade na aplicação da pena, sem vinculação com a infração atual, constituindo, portanto, nova apenação de conduta passada, a qual o indivíduo já foi julgado e condenado, violando, também, o princípio da culpabilidade (KARAM, 2003, p. 316-323).

${ }^{115}$ No caso do Brasil, o condenado teria que cumprir 30 anos da pena em regime fechado, que é o limite estabelecido no artigo 75, do Código Penal. Ressalta-se que alguns países só admitem a pena de prisão perpétua mediante a possibilidade da obtenção, pelo condenado, do livramento condicional após 25 anos de cumprimento da pena privativa de liberdade (CERNICCHIARO, op. cit., p. 290-291).

${ }^{116}$ BLANCO LOZANO, Carlos; TinOCO PASTRANA, Ángel. Prisión y resocialización. Madrid: Difusión Jurídica, 2009. p. 74.
} 
Medidas legislativas como esta são consequências da demanda, pela sociedade, de um Direito Penal cada vez mais intervencionista, que propicia ao Estado um poder ilimitado e irracional, justificado sob o manto da segurança pública ${ }^{117}$.

As regras para progressão estão previstas no artigo 112, da Lei de Execução Penal, que estabelece que a transferência para o regime menos rigoroso será determinada pelo juiz quando o preso tiver cumprido ao menos 1/6 (um sexto) da pena no regime anterior, e ostentar bom comportamento carcerário ${ }^{118}$, comprovado pelo diretor do estabelecimento, respeitadas as normas que vedam a progressão.

Assim, cumpridos esses requisitos de ordem temporal e subjetivo, tem o condenado o direito à progressão de pena.

Em relação ao requisito objetivo do tempo de cumprimento de pena, necessário esclarecer que esses valores incidem sobre a pena total aplicada ao réu, e não sobre a pena unificada, conforme o enunciado 715, da súmula do Supremo Tribunal Federal. Percebese, aqui, que pode haver casos em que o réu cumpre a pena privativa de liberdade inteiramente em regime fechado, não atendendo aos fins de reinserção social da pena, um dos desdobramentos do princípio da humanidade, pois, após o cumprimento de 30 anos de pena privativa de liberdade, vai do regime fechado diretamente à liberdade.

Para que o condenado ingresse no regime aberto, deve ele aceitar o programa e as condições impostas pelo juiz, tais como permanecer no local que for designado durante o repouso noturno e nos dias de folga, sair para o trabalho e retornar, nos horários fixados, não se ausentar da cidade onde reside sem autorização judicial, comparecer a Juízo, para informar e justificar as suas atividades quando for determinado, além de trabalhar, ou comprovar possibilidade de fazê-lo imediatamente, e apresentar, pelos seus antecedentes ou pelo resultado dos exames a que foi submetido, fundados indícios de que irá ajustar-se,

\footnotetext{
${ }^{117}$ GeRLACK NETO, Martinho Otto. O resgate do sistema progressivo de execução da pena [Comentário de jurisprudência]. Revista Brasileira de Ciências Criminais, São Paulo, v. 14, n. 63, p. 334-335, nov./dez. 2006. ${ }^{118} \mathrm{O}$ mau comportamento causado pela dificuldade de se ajustar às exigências da disciplina do ambiente carcerário ou pela resistência aos efeitos da prisionização não deveria ser critério para decidir sobre o livramento condicional ou sobre a natureza do estabelecimento que recolhe o preso (FrAGOSO, Heleno Cláudio. Alternativas da pena privativa de liberdade. Revista de Direito Penal, Rio de Janeiro, n. 29, p. 13-14, jan./jun. 1980).
} 
com autodisciplina e senso de responsabilidade, ao novo regime, conforme artigos 113 a 116, da Lei de Execução Penal.

Estarão dispensados do trabalho, admitindo o recolhimento em residência particular, o condenado em regime aberto maior de 70 anos, o acometido de doença grave, a condenada com filho menor ou deficiente físico ou mental, e a gestante, a teor do artigo 117, da lei.

Apesar dessa regulação do regime aberto, não há estabelecimentos adequados para o cumprimento desta pena, ficando os condenados em prisão albergue domiciliar, mesmo não se enquadrando nas hipóteses do artigo citado acima, sem possibilidade de fiscalização, pelo Estado, do cumprimento da pena ${ }^{119}$.

Estarão sujeitos à regressão de regime de cumprimento de pena, conforme artigo 118, da Lei de Execução Penal, passando do mais brando para o mais rigoroso, os condenados que praticarem fato definido como crime doloso ou falta grave, ou que sofrerem condenação, por crime anterior, cuja pena, somada ao restante da pena em execução, torne incabível o regime a que está submetido.

Ainda, serão transferidos do regime aberto se frustrarem os fins da execução ou se não pagarem, podendo, a multa cumulativamente imposta, de acordo com parágrafo primeiro deste artigo, e com o artigo 36, § $2^{\circ}$, do Código Penal.

\footnotetext{
$\overline{119}$ É entendimento de alguns julgadores que a falta de vaga em estabelecimento adequado não autoriza o cumprimento da pena em regime mais gravoso. Mesmo que a falta de vaga se dê no regime semiaberto, deve o condenado aguardar a vaga no regime aberto e não no fechado (BRASIL. Superior Tribunal de Justiça. Habeas corpus $n^{\mathbf{0}}$ 291.650, da 5 ${ }^{\text {a }}$ Turma, Rel.: Ministro Moura Ribeiro, j. 20.05.2014, DJe 23.05.2014; BRASIL. Supremo Tribunal Federal. Habeas corpus $n^{\circ} 118.492$, da $2^{\mathrm{a}}$ Turma, Rel.: Ministro Ricardo Lewandowski, j. 06.11.2013, DJe 19.11.2013). Apesar de esse entendimento, causado pela falta de estabelecimentos suficientes para o regime semiaberto, comprometer a eficácia da pena privativa de liberdade, bem como a sua função de reintegração social, essa solução consagra os direitos fundamentais do condenado, em especial a legalidade e individualização da pena, que não podem ser tolhidos em virtude da inércia do poder estatal (ARAÚJO, Fábio Roque da Silva. Omissão estatal e prisão domiciliar. Revista Magister de Direito Penal e Processual Penal, Porto Alegre, v. 9, n. 51, p. 58-59, dez./jan. 2013). Mas, nos casos em que o preso ficar, por exemplo, detido provisoriamente e, depois de fixada a pena, ele ter direito a ir do regime fechado para o aberto, o tribunal superior negará essa progressão, que deveria ser aceita, para o preso não ficar mais tempo que o necessário em regime mais gravoso, quando já cumpriu os requisitos objetivos para estar em regime mais ameno (VALOIS, Luis Carlos. Conflito entre ressocialização e o princípio da legalidade na execução penal. Rio de Janeiro: Lumen Juris, 2013. p. 166-173).
} 
Salvo caso de nova condenação, cuja pena, somada ao restante da pena em execução, torne incabível o regime a que está submetido, o condenado deve ser previamente ouvido à determinação da regressão de regime.

2.1.2. Da substituição da pena privativa de liberdade por penas restritivas de direitos

O Código Penal prevê, em seu artigo 44, a substituição da pena privativa de liberdade por penas restritivas de direitos, medida que evita o encarceramento de curta duração, quando preenchidos os requisitos trazidos por este mesmo artigo ${ }^{120}$. As penas restritivas de direitos, previstas no artigo 43, são: prestação pecuniária, perda de bens e valores, prestação de serviço à comunidade ou a entidades públicas, interdição temporária de direitos e limitação de fim de semana.

A adoção de medidas substitutivas à pena privativa de liberdade rompe a barreira do apego ao aprisionamento daqueles que cometem infrações penais como única solução de repressão e prevenção. Diante dos elevados índices de reincidência, é deixada de lado a pretensão de utilizar o cumprimento da pena privativa de liberdade como oportunidade para a reeducação, reintegração e reinserção social do condenado ${ }^{121}$, especialmente nos casos de crimes de menor potencial ofensivo.

A aplicação da pena restritiva de direitos evita a dessocialização do condenado, pois não o retira do convívio social, e dá proporcionalidade entre o crime cometido e a

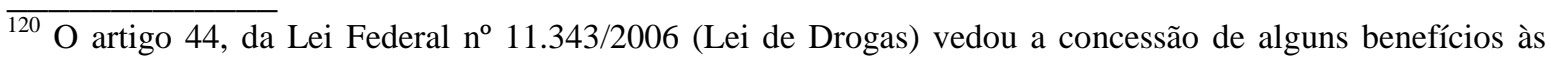
pessoas condenadas pelos crimes dessa lei, dentre eles a conversão da pena privativa de liberdade em restritiva de direitos. Mas, o Supremo Tribunal Federal já se posicionou pela inconstitucionalidade de parte deste dispositivo, no que tange à vedação da conversão da pena privativa de liberdade em restritivas de direitos (BRASIL. Supremo Tribunal Federal. Habeas corpus n ${ }^{\circ}$ 97.256, plenário, Rel.: Ministro Ayres Britto, j. 01.09.2010, DJ 16.12.2010).

${ }^{121}$ Reale JR., Miguel. Penas restritivas. Ciência Penal, Rio de Janeiro, v. 7, n. 1, p. 73-74, 1981. Em estudo realizado na Espanha, verificou-se que as taxas de reincidência obtidas após o cumprimento de medidas restritivas de liberdade eram a metade da obtida em comparação com o cumprimento da pena privativa de liberdade (VILlacampa Estiarte, Carolina; Torres Rosell, Núria; LuQue Reina, María Eulália. Penas alternativas a la prisión y reincidencia: un estudio empírico. Navarra: Aranzadi, 2006. p. 143-144).
} 
pena aplicada, quando o caso não é merecedor de tratamento penal severo, aquele que insere o condenado no sistema prisional ${ }^{122}$.

Contudo, para que a aplicação dessa substituição funcione e para que a pena alcance sua finalidade, são necessários investimentos para a correta aplicação das penas prevista em lei, além do acompanhamento da execução delas. É necessário assegurar que a pena seja individualizada de maneira adequada, em relação às condições da substituição, e que seja aplicada e executada como medida efetiva de política criminal, e não apenas como solução para desocupar vagas nos presídios ${ }^{123}$.

Para que a pena de prestação de serviços à comunidade alcance os objetivos a ela propostos, é necessário que o Estado possua estrutura adequada e suficiente para a fiscalização, acompanhamento e monitoramento da execução desta pena. Ainda, apenas com a correta aplicação das penas restritivas de direitos é que vai se criar na sociedade a cultura acerca dessas formas alternativas de intervenção penal, diferentes da prisão, sem que se dissemine a ideia de que elas são sinônimas de impunidade. Apenas com a comprovação da efetividade dessas penas é que a sociedade apoiará que elas cumprem melhor as suas finalidades do que a privação de liberdade para os delitos de menor potencial ofensivo $^{124}$.

Essas penas têm a possibilidade de abrir um diálogo entre o condenado e a sociedade, moderado por um Estado Democrático de Direito, para a concretização de seus fins ${ }^{125}$.

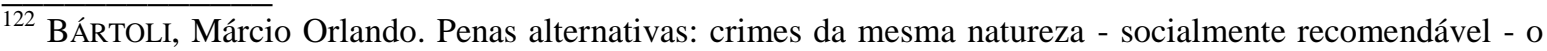
art. 44 par. $3^{\circ}$. do CP. In: Escritos em homenagem a Alberto Silva Franco. São Paulo: Revista dos Tribunais, 2003. p. 298-301.

${ }^{123}$ TOLEDO, Francisco de Assis. Aplicação da pena: pena alternativa ou substitutiva. In: DotTI, René Ariel; REale JR., Miguel; Toledo, Francisco de Assis; SheCAIRA; Sergio Salomão; AzeVedo; David Teixeira de; LOPES, Mauricio Antonio Ribeiro. (Orgs.). Penas restritivas de direitos: Críticas e comentários às penas alternativas. São Paulo: Revista dos Tribunais, 1999. p. 139.

${ }^{124}$ GOMES, Geder Luiz Rocha. A trajetória da central nacional de penas e medidas alternativas do Ministério da Justiça. Revista do Conselho Nacional de Política Criminal e Penitenciária, Brasília, v. 1, n. 21, p. 95-96, 2008.

${ }^{125}$ DotTI, 1999, p. 98.
} 
O artigo 44, do Código Penal, estabelece que as penas restritivas de direitos são autônomas e substituem as penas privativas de liberdade quando a fixação desta pena não for superior a 4 (quatro) anos e o crime não for cometido com violência ou grave ameaça à pessoa, ou, qualquer que seja a pena aplicada, se o crime for culposo. O réu não pode ser reincidente em crime doloso, e a culpabilidade, os antecedentes, a conduta social e a personalidade do condenado, bem como os motivos e as circunstâncias do crime devem indicar que essa substituição seja suficiente.

Ainda, de acordo com os parágrafos deste artigo, se a condenação à pena privativa de liberdade for igual ou inferior a um ano, a substituição pode ser feita por multa ou por uma pena restritiva de direitos; e, se superior a um ano, a pena privativa de liberdade pode ser substituída por uma pena restritiva de direitos e multa ou por duas restritivas de direitos.

A reincidência genérica não impede esta substituição, pois, conforme o artigo 44, § $3^{\circ}$, do Código Penal, se o condenado for reincidente, o juiz poderá aplicar a substituição, desde que, em face de condenação anterior, a medida seja socialmente recomendável e a reincidência não tenha se operado em virtude da prática do mesmo crime ${ }^{126}$.

Se ocorrer o descumprimento injustificado da pena restritiva imposta, esta se converte em privativa de liberdade, deduzindo-se, no cálculo da pena privativa de liberdade a ser executada, o tempo cumprido da pena restritiva de direitos, respeitado o saldo mínimo de trinta dias de detenção ou reclusão, de acordo com o artigo $44, \S 4^{\circ}$, do Código Penal ${ }^{127}$.

\footnotetext{
$\overline{126}$ A reincidência específica, aquela que se dá em virtude da prática do mesmo crime, impede a substituição da pena privativa de liberdade por restritiva de direitos, pois o legislador entendeu que, nesses casos, é necessário um tratamento penal mais rigoroso. Contudo, a reincidência específica não significa, necessariamente, que a ação precisa de maior reprovação, podendo este dispositivo ser entendido como uma afronta à isonomia e à dignidade humana, pois utiliza um dado relativo à periculosidade para o cálculo da pena (BÁRTOLI, 2003, p. 293-298).

${ }^{127}$ Complementa o artigo 181, da Lei de Execução Penal, dispondo que a pena de prestação de serviços à comunidade será convertida em privação de liberdade quando o condenado não for encontrado por estar em lugar incerto e não sabido, ou desatender a intimação por edital, não comparecer, injustificadamente, à entidade ou programa em que deva prestar serviço, recusar-se, injustificadamente, a prestar o serviço que lhe foi imposto, praticar falta grave, ou sofrer condenação por outro crime à pena privativa de liberdade, cuja execução não tenha sido suspensa. A pena de limitação de fim de semana será convertida quando o condenado
} 
E, conforme o último parágrafo deste artigo, sobrevindo condenação à pena privativa de liberdade, por outro crime, o juiz da execução penal decidirá sobre a conversão da pena restritiva de direitos em pena privativa de liberdade, podendo deixar de converter a pena se for possível ao condenado cumprir a pena substitutiva anteriormente imposta.

Conforme o artigo 55, do Código Penal, as penas restritivas de direitos devem ter a mesma duração da pena privativa de liberdade substituída, ressalvado o artigo 46, $\S 4^{\circ}$, que determina que se a pena substituída for superior a um ano, é facultado ao condenado cumprir a pena substitutiva em menor tempo, mas nunca inferior à metade do tempo da pena privativa de liberdade fixada.

\subsubsection{Da prestação pecuniária}

A prestação pecuniária é uma das espécies da pena de prestação social alternativa, prevista no artigo $5^{\circ}$, inciso XLVI, alínea “d”, da Constituição Federal.

A substituição da pena privativa de liberdade por esta restritiva de direitos se justifica, pois para algumas infrações não é necessário retirar o indivíduo do meio social, privando-o de sua liberdade, para a reprovação e prevenção do crime, basta a reparação do dano causado. Esta reparação, aliás, também é utilizada pelo Código Penal para reduzir a pena em outros crimes, como nos casos de arrependimento posterior, trazido pelo artigo 16, do código, e de atuante genérica, prevista no artigo 65, inciso III, alínea “b" 128 .

A prestação pecuniária consiste, a teor do artigo $45, \S 1^{\circ}$, do Código Penal, no pagamento em dinheiro à vítima, a seus dependentes ou a entidade pública ou privada com

não comparecer ao estabelecimento designado para o cumprimento da pena, recusar-se a exercer a atividade determinada pelo Juiz, não for encontrado por estar em lugar incerto e não sabido, ou desatender a intimação por edital, praticar falta grave, ou sofrer condenação por outro crime à pena privativa de liberdade, cuja execução não tenha sido suspensa; e a pena de interdição temporária de direitos será convertida quando o condenado exercer, injustificadamente, o direito interditado, não for encontrado por estar em lugar incerto e não sabido, desatender a intimação por edital, ou sofrer condenação por outro crime à pena privativa de liberdade, cuja execução não tenha sido suspensa.

${ }^{128}$ DOTTI, 1999, p. 106-109. 
destinação social, de importância fixada pelo juiz, não inferior a 1 (um) salário mínimo nem superior a 360 (trezentos e sessenta) salários mínimos.

Esse valor pago é deduzido do montante de eventual condenação em ação de reparação civil, se coincidentes os beneficiários. Se houver aceitação destes, ainda, conforme artigo 45, $2^{\circ}$, do Código Penal, a prestação pecuniária pode consistir em prestação de outra natureza, que é qualquer prestação com valor econômico, mas que não consista em entrega de dinheiro, tais como entrega de cestas básicas ${ }^{129}$ e oferta de mão-deobra $^{130}$.

Essa pronta reparação do dano é importante para a humanização do Direito Penal, pois a vítima não é abandonada suportando as consequências do crime; assim, diminuemse os efeitos causados pelo crime, através da restituição, ressarcimento, composição ou indenização $^{131}$.

Diferentemente da multa reparatória, para a aplicação desta pena não é necessária a produção de um prejuízo material, podendo a prestação se dar em virtude de um dano moral, nos casos, por exemplo, de crimes contra a honra, tendo em vista a proteção constitucional dos bens personalíssimos, prevista no artigo $5^{\circ}$, incisos $\mathrm{V}$ e $\mathrm{X}$, da Constituição Federal $^{132}$.

A obrigação de indenizar o dano, efeito extrapenal genérico da sentença penal condenatória, prevista no artigo 91, inciso I, do Código Penal, passa a ser um dos principais efeitos na imposição da prestação pecuniária como pena, com valor determinado pelo juiz na prolação da sentença. Contudo, esta pena não se confunde com o valor indenizatório imposto, posteriormente, no juízo cível, do qual a prestação pecuniária será

\footnotetext{
${ }^{129}$ O artigo 17, da Lei Federal no 11.340/2006 (Lei Maria da Penha) faz restrição sobre a prestação de outra natureza, proibindo que, nos casos de violência doméstica e familiar contra a mulher, haja penas de entrega de cesta básica ou outras de prestação pecuniária, bem como a substituição de pena que implique no pagamento isolado de multa.

${ }^{130}$ GRECO, Rogério. Direitos humanos, sistema prisional e alternativas à privação de liberdade. São Paulo: Saraiva, 2011. p. 418.

${ }^{131}$ DOTTI, 1999, p. 107-108. Nesse mesmo sentido, SHECAIRA, 1999, p. 228-229.

${ }^{132}$ DOTTI, op. cit., p. 109-110.
} 
deduzida. A indenização do juízo cível tem caráter reparatório, enquanto a prestação pecuniária tem, também, caráter aflitivo, pois não deixa de ser uma sanção criminal ${ }^{133}$.

\subsubsection{Da perda de bens e valores}

A perda de bens está prevista na Constituição Federal em seu artigo $5^{\circ}$, inciso XLVI, alínea "b”, e no Código Penal, no artigo 43, inciso II, como uma pena restritiva de direitos.

Conforme disposto no artigo $45, \S 3^{\circ}$, do Código Penal, a perda de bens e valores pertencentes aos condenados dar-se-á, salvo existência de legislação especial, em favor do Fundo Penitenciário Nacional ${ }^{134}$, e seu valor terá como teto - o que for maior - o montante do prejuízo causado ou do provento obtido pelo agente ou por terceiro, em consequência da prática do crime.

Por bens, entendem-se coisas materiais ou imateriais que têm um valor econômico e podem servir de objetos em uma relação jurídica; por valores, coisas com interesse econômico, como, por exemplo, títulos de crédito ${ }^{135}$.

Esta pena restritiva de direitos, que não se confunde com o efeito extrapenal da condenação previsto no artigo 91, inciso II, do Código Penal, é uma apropriação de coisas móveis ou imóveis pertencentes ao agente, destinado, salvo legislação especial, ao Fundo Penitenciário Nacional, instituído pela Lei Complementar nº 79/1994 e regulamentado pelo Decreto $n^{\circ}$ 1.093/1994, cujos recursos são utilizados para a manutenção e melhoria dos estabelecimentos prisionais, dos serviços penitenciários e das atividades funcionais, além de oferecer programas de assistência aos presos, aos internados carentes e às vítimas do crime.

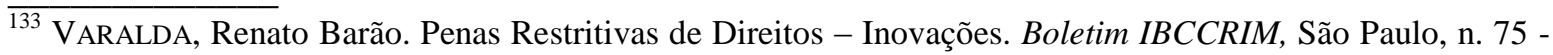
encarte, p.VII-VIII, fev. 1999.

${ }^{134}$ Uma exceção a este dispositivo é a previsão do artigo 243, da Constituição Federal, que estabelece que as propriedades rurais e urbanas de qualquer região do país onde forem localizadas culturas ilegais de plantas psicotrópicas ou exploração de trabalho escravo serão expropriadas e destinadas à reforma agrária e a programas de habitação popular.

${ }^{135}$ DOTTI, 1999, p. 111.
} 
Por ter natureza compensatória, para a aplicação desta pena é necessário que o crime produza um prejuízo economicamente demonstrável, ou que o autor da infração, ou terceiro, tenham auferido um proveito de igual natureza com a prática do crime ${ }^{136}$.

A aplicação de uma pena que visa recuperar o resultado da prática criminosa, impedindo o criminoso de desfrutar do saldo do crime, é interessante, em especial, em atenção às novas formas de criminalidade econômica. Essa pena, nesses casos, ainda, assume considerável escopo de prevenção ${ }^{137}$.

A perda de bens e valores, por fim, não se assemelha ao confisco, pois o legislador limitou o bem ou o valor perdido ao montante do prejuízo causado ou do provento obtido pelo agente ou por terceiro ${ }^{138}$. Ademais, por ser uma sanção criminal, deve observar os princípios penais, como o da pessoalidade das penas, razão pela qual a pena não deve ser suportada, por exemplo, pelos filhos do condenado ${ }^{139}$.

2.1.2.3. Da prestação de serviços à comunidade ou a entidades públicas

O artigo $5^{\circ}$, inciso XLVI, alínea “d”, da Constituição Federal, prevê a pena de prestação social alternativa como gênero de pena a ser adotada em nosso ordenamento penal, da qual a prestação de serviços à comunidade ou a entidades públicas é espécie.

Essa prestação deve atender aos princípios penais que regem as demais penas, como também à dignidade humana, motivo pelo qual não pode ser imposta ao acusado alguma atividade que seja a ele vexatória ou humilhante, por exemplo.

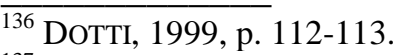

137 SiCA, Leonardo. Direito penal de emergência e alternativas à prisão. São Paulo: Revista dos Tribunais, 2002. p. 185.

${ }^{138}$ SHECAIRA, 1999, p. 230-231.

${ }^{139}$ Delmanto, Roberto; Delmanto JR., Roberto; Delmanto, Fabio Machado de Almeida. Perda de bens e multa substitutiva. Boletim IBCCRIM, São Paulo, v. 7, n. 85, p. 10, dez. 1999.
} 
Esta pena restritiva de direitos, regulada no artigo 46, do Código Penal, consiste na atribuição de tarefas gratuitas ao condenado, conforme suas aptidões, e é aplicável às condenações superiores a 6 (seis) meses de privação da liberdade.

É contraditória a adoção de uma legislação que só permite a substituição da pena privativa de liberdade por prestação de serviços nos casos de condenações superiores a 6 meses quando esta também quer ampliar a opção de alternativas à pena privativa de liberdade. A prestação de serviços, com caráter pedagógico-preventivo, não pode substituir a privação de liberdade nesses casos, enquanto que não há limite temporal para a pena de interdição temporária de direitos ou limitação de fim de semana. Assim, impede o legislador da adoção, pelo juiz, da pena que pode se adequar melhor a essas situações de pequenas infrações ${ }^{140}$.

A prestação de serviços deve ser cumprida em entidades assistenciais, hospitais, escolas, orfanatos ou outros estabelecimentos congêneres, em programas comunitários ou estatais, à razão de uma hora por dia de condenação, fixadas de modo a não prejudicar a jornada normal de trabalho do condenado ${ }^{141}$.

Destaca-se, nesta pena, seu sentido utilitário, que, sem o estigma do preconceito causado pelo cárcere, insere o condenado na sociedade para a realização de uma atividade socialmente útil, dando à pena um caráter humano e social, que se projeta nos cidadãos, que deixam de discriminar as pessoas criminalmente processadas ${ }^{142}$.

Como já mencionado, é necessário ressaltar que esta pena não se confunde com trabalhos forçados, proibida constitucionalmente ${ }^{143}$.

A prestação de serviços à comunidade não priva o indivíduo de sua liberdade e evita a inserção dele no sistema carcerário. Ainda, a substituição da pena é feita por uma

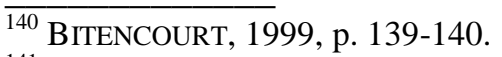

${ }^{141}$ De acordo com o artigo 149, parágrafo $1^{\circ}$, da Lei de Execução Penal, o trabalho terá a duração de 8 (oito) horas semanais e será realizado aos sábados, domingos e feriados, ou em dias úteis, de modo a não prejudicar a jornada normal de trabalho do condenado, nos horários estabelecidos pelo juiz.

${ }_{142}$ DOTTI, 1999, p. 118-119.

${ }^{143}$ Conforme item 1.2.2.1.4.
} 
atividade que não prejudica a dignidade do condenado, nem a vida normal dele, trazendo resultados positivos para a sociedade e gerando um senso de responsabilidade para desestimulá-lo a retornar à criminalidade ${ }^{144}$.

\subsubsection{Da interdição temporária de direitos}

No Código Penal, a interdição temporária de direitos encontra-se prevista nos artigos 43 , inciso $\mathrm{V}$, e 47, que, taxativamente, prevê as restrições que podem ser aplicadas e que impedem o gozo ou o exercício de determinados direitos do condenado por um período preestabelecido ${ }^{145}$. Mas, este gênero de pena também pode ser encontrado em outras legislações, suspendendo ou interditando direitos relativos à matéria lá tratada ${ }^{146}$.

A interdição restringe do indivíduo seus direitos que usufrui na sua vida social, que tem como finalidade preventiva especial a conscientização do agente, durante a execução da pena, dos deveres por ele violados ${ }^{147}$.

As penas restritivas de direitos, na modalidade interdição temporária de direitos, estão arroladas nos incisos do artigo 47, do Código Penal e são: proibição do exercício de cargo, função ou atividade pública, bem como de mandato eletivo; proibição do exercício de profissão, atividade ou ofício que dependam de habilitação especial, de licença ou autorização do poder público; suspensão de autorização ou de habilitação para dirigir veículo; proibição de frequentar determinados lugares ${ }^{148}$; e proibição de inscrever-se em concurso, avaliação ou exames públicos.

Para que essas penas guardem uma correlação lógica com o fato praticado ${ }^{149}$, o Código Penal dispõe, no artigo 56, que a proibição do exercício de cargo, função ou

\footnotetext{
$\overline{{ }^{144} \text { CERNICCHIARO, }}$ 1995-a, p. 137-138.

${ }^{145}$ DoTTI, 1999, p. 119.

146 A Lei Federal n ${ }^{\circ} 8.429 / 1992$ (Lei de improbidade administrativa) prevê, por exemplo, a suspensão de direitos políticos.

${ }^{147}$ SHECAIRA, 1999, p. 233-324.

${ }^{148}$ Esta proibição, também prevista no artigo 89, inciso II, da Lei Federal no 9.099/95 e no artigo 319, inciso II, do Código de Processo Penal, tem sido utilizada para proibir pessoas envolvidas em casos de violência em estádios de futebol de frequentar estes locais por período determinado de tempo.

${ }^{149}$ SHECAIRA, op. cit., p. 233.
} 
atividade pública, bem como de mandato eletivo, que não se confunde com a perda de cargo, função pública ou mandato eletivo, efeito da condenação, previsto no artigo 92, inciso I, do Código Penal, e a proibição do exercício de profissão, atividade ou ofício que dependam de habilitação especial, de licença ou autorização do poder público aplicam-se aos crimes cometidos no exercício de profissão, atividade, ofício, cargo ou função, sempre que houver violação dos deveres que lhes são inerentes.

Em relação à pena de suspensão de autorização ou de habilitação para dirigir veículo, esta perdeu um pouco de sentido no Código Penal após a entrada em vigor da Lei Federal no 9.503/97 (Código de Trânsito Brasileiro), cujo artigo 292 prevê a aplicação desta pena como principal, isolada ou cumulativamente com outras penalidades para os crimes de trânsito, situação em que deve ser aplicada a legislação especial, como determina o artigo 12, do Código Penal, e artigo 291, do Código de Trânsito Brasileiro.

A pena de proibição de frequentar determinados lugares, apesar de ser uma inovação em nossa legislação, de 1998, é marcada por sua ineficácia, tendo em vista que não é possível, diante do cenário brasileiro, fiscalizar o cumprimento desta pena ${ }^{150}$.

2.1.2.5. Da limitação de fim de semana

O artigo 48, do Código Penal, dispõe sobre a pena de limitação de fim de semana, estabelecendo a obrigação de permanecer, aos sábados e domingos, por 5 (cinco) horas diárias, em casa de albergado ou outro estabelecimento adequado.

Enquanto os condenados estiverem nesses locais, poderão ser ministrados cursos e palestras ou atribuídas atividades educativas. Ainda, conforme o artigo 152, parágrafo único, da Lei de Execução Penal, nos casos de violência doméstica contra a mulher, o juiz

\footnotetext{
${ }^{150}$ GRECO, 2011, p. 429. Para fiscalizar essa pena seria possível, se houvesse previsão legal, a utilização do monitoramento eletrônico, de modo a acompanhar os movimentos do condenado e verificar se ele frequentou local proibido pela pena a ele imposta. Contudo, a avaliação da necessidade dessa medida deveria se dar sobre a análise da personalidade do agente, circunstância do delito e outros fatores, e não sobre a mera ineficácia do Estado em fiscalizar tal pena (BOTTINI, Pierpaolo Cruz. Aspectos pragmáticos e dogmáticos do monitoramento eletrônico. In: BRASIL. MinisTÉRIO DA JUSTIÇA. CONSELHO NACIONAL DE POLÍTICA CRIMINAL E PENITENCIÁRIA. Monitoramento eletrônico: uma alternativa à prisão?; experiências internacionais e perspectivas no Brasil. Brasília: CNPCP, 2008. p. 172-174).
} 
poderá determinar o comparecimento obrigatório do agressor a programas de recuperação e reeducação.

Esta pena, apesar de incluída no rol de penas substitutivas à pena privativa de liberdade, coloca o condenado em instituição destinada aos condenados que cumprem a pena privativa de liberdade em regime aberto - nas casas de albergados ou outro estabelecimento adequado ${ }^{151}$. Além desta incoerência e de não haver estabelecimentos apropriados para todos que necessitem, não há estrutura suficiente para o efetivo cumprimento desta pena, tendo em vista que as escassas casas de albergados pelo país não têm estrutura organizacional e pessoal técnico para receber as pessoas condenadas a esta pena e, ainda, oferecer-lhes cursos, palestras ou atividades educativas, o que daria à pena caráter meramente retributivo ${ }^{152}$.

Assim, por falta de estrutura física e de pessoal, o cumprimento desta pena fica prejudicado, podendo levar os juízes a escolherem outras penas restritivas de direitos, mesmo que essa seja a adequada para o caso.

\subsubsection{Da multa}

A pena de multa não está prevista dentre as penas restritivas de direitos arroladas no artigo 43, do Código Penal, mas, conforme o artigo 44, § $2^{\circ}$, em casos de condenação igual ou inferior a um ano, a substituição da pena privativa de liberdade pode ser feita por multa ou por uma pena restritiva de direitos, e, se a condenação for superior a um ano, a pena

\footnotetext{
${ }^{151}$ Contudo, pelo país há escassas casas de albergado, tendo em vista que a Administração Pública não cumpriu o prazo de um ano para adotar as medidas necessárias para a implantação desta pena, como previsto na Lei Federal $n^{\circ} 7209 / 84$, em seu artigo $3^{\circ}$. Vê-se, assim, mais uma vez, o descaso com o sistema carcerário brasileiro, pois esta pena, se aplicada, não terá qualquer efetividade, servindo para aumentar o sentimento de impunidade existente diante das penas restritivas de direitos. Os magistrados mais prudentes preferirão adotar outras espécies de penas restritivas de direitos a esta, cujo cumprimento não é possível por falta de estabelecimentos adequados (BITENCOURT, 1999, p. 152-153).

${ }^{152}$ SHECAIRA, 1999, p. 234.
} 
pode ser substituída por uma pena restritiva de direitos e multa ou por duas restritivas de direitos, atendidos os demais requisitos dos incisos desse artigo ${ }^{153}$.

Desta forma, além da sua cominação como pena principal em alguns tipos penais, ela também foi posta como substituta da pena privativa de liberdade nos casos em que é cabível tal alternativa.

Assim, a pena de multa deixa de ser uma pena que normalmente acompanha a cominação da pena privativa de liberdade e passa, aqui, a substituí-la. Não é possível manter um sistema em que é possível privar a liberdade de alguém por um curto espaço de tempo, então a multa surge como substitutivo apropriado e de utilização cada vez mais frequente, cujos benefícios superam possíveis desvantagens ${ }^{154}$.

A pena de multa consiste no pagamento ao fundo penitenciário de quantia fixada na sentença, atendendo, principalmente, a situação econômica do réu, e calculada em diasmulta, podendo ser de, no mínimo, 10 e, no máximo, de 360 dias-multa. O valor do diamulta também é fixado pelo juiz, não podendo ser inferior a 1/30 (um trigésimo) do maior salário mínimo mensal vigente ao tempo do fato, nem superior a 5 (cinco) vezes esse salário, conforme o artigo 49, do Código Penal.

Caso, em virtude da situação econômica do réu, o juiz considerar que a multa seja ineficaz, embora aplicada no máximo, esta pode ser aumentada até o triplo, conforme artigo 60, $\S 1^{\circ}$, do Código Penal.

Desta forma, com a utilização do sistema de dia-multa, esta sanção pode se adequar às condições econômicas do réu, de forma a cumprir as finalidades de prevenção e

\footnotetext{
$\overline{153} \mathrm{O}$ artigo $60, \S 2^{\circ}$, do Código Penal, permite a substituição da pena privativa de liberdade, não superior a 6 (seis) meses, pela pena de multa, observados os critérios dos incisos II e III, do artigo 44, do deste código, que dispõem que a substituição é possível se o réu não for reincidente em crime doloso e se a culpabilidade, os antecedentes, a conduta social e a personalidade do condenado, bem como os motivos e as circunstâncias indicarem que essa substituição seja suficiente. Desta forma, a substituição é possível mesmo que o crime seja cometido com violência ou grave ameaça, pois para a aplicação da multa substitutiva deste artigo não é necessária a observância do inciso I, do artigo 44, do Código Penal (DELMANTO; DELMANTo JR.; DELMANTO, 1999, p. 10).

${ }^{154}$ PRADO, Luiz Regis. Multa penal: doutrina e jurisprudência. 2. ed. São Paulo: Revista dos Tribunais, 1993. p. 90.
} 
reprovação, tanto dos condenados com pouca possibilidade econômica, quanto dos que têm maiores condições.

Com a nova redação do artigo 51, do Código Penal, dada pela Lei Federal $n^{\circ}$ 9.268/1996, a pena de multa não pode ser convertida em pena privativa de liberdade caso não seja cumprida, ao contrário das demais penas restritivas de direitos, cujo descumprimento leva à conversão da pena pela privativa de liberdade, conforme dispõe o artigo $44, \S 4^{\circ}$, do Código Penal.

2.1.3. Da suspensão da execução da pena privativa de liberdade

A legislação brasileira prevê dois institutos que visam à suspensão da execução da pena privativa de liberdade, permitindo ao condenado cumprir o restante da pena em meio livre. São eles: a suspensão condicional da pena e o livramento condicional.

2.1.3.1. Da suspensão condicional da pena

A suspensão condicional da pena evita a execução da pena privativa de liberdade de curta duração, bem como os efeitos nocivos do encarceramento, e propicia ao condenado a oportunidade de viver em liberdade corretamente, aderindo às regras sociais ${ }^{155}$.

Prevista no artigo 77, do Código Penal, ela prevê que a execução da pena privativa de liberdade, não superior a 2 (dois) anos, poderá ser suspensa, por 2 (dois) a 4 (quatro) anos, desde que o condenado não seja reincidente em crime doloso, a culpabilidade, os antecedentes, a conduta social e personalidade do agente, bem como os motivos e as

$\overline{155}$ TuCCI, Rogério Lauria. Suspensão condicional da pena. Ciência Penal, Rio de Janeiro, v. 6, n. 2, p.80, 1980 . 
circunstâncias autorizem a concessão do benefício ${ }^{156}$, e não seja indicada ou cabível a substituição prevista no artigo 44, do mesmo código.

Desde que preenchidos os requisitos objetivos e subjetivos, a suspensão condicional da pena é um direito subjetivo do condenado.

Ainda, de acordo com os parágrafos do artigo 77, do Código Penal, a condenação anterior a pena de multa não impede a concessão do benefício; e a execução da pena privativa de liberdade, não superior a 4 (quatro) anos, poderá ser suspensa, por quatro a seis anos, desde que o condenado seja maior de 70 (setenta) anos de idade, ou haja razões de saúde que justifiquem a suspensão.

Nos artigos seguintes, o texto legal continua a regular a suspensão condicional da pena, estabelecendo que, durante o prazo da suspensão, o condenado ficará sujeito à observação e ao cumprimento das condições estabelecidas pelo juiz. No primeiro ano do prazo, o condenado deve prestar serviços à comunidade ou submeter-se à limitação de fim de semana, a menos que, se houver reparado o dano, salvo impossibilidade de fazê-lo, e se as circunstâncias do artigo 59, do Código Penal, lhe forem inteiramente favoráveis, o juiz substitua essa exigência pelas seguintes condições, aplicadas cumulativamente: proibição de frequentar determinados lugares, proibição de ausentar-se da comarca onde reside, sem autorização do juiz, comparecimento pessoal e obrigatório a juízo, mensalmente, para informar e justificar suas atividades.

A sentença pode, ainda, especificar outras condições a que fica subordinada a suspensão, desde que adequadas ao fato e à situação pessoal do condenado.

Essas condições a que ficam submetidas a suspensão da pena, de cunho punitivo e temporário $^{157}$, vem unidas a obrigações socialmente úteis, como a reparação do ilícito

\footnotetext{
$\overline{156}$ Tendo em vista que a culpabilidade e conduta social do apenado devem mostrar a conveniência da suspensão condicional da pena, em face da reprovação e prevenção do delito, esta pode ser obstada até aos não reincidentes, quando estes não preencherem este requisito subjetivo (MUAKAD, 1996, p. 74).

${ }^{157}$ ALMEIDA, José Eulálio Figueiredo de. Sursis como medida sancionatória substitutiva da pena privativa de liberdade. Revista Síntese de Direito Penal e Processual Penal, Porto Alegre, v. 4, n. 22, p. 27, out./nov. 2003.
} 
cometido e prestação de serviços à comunidade, de modo que a suspensão condicional da pena não represente uma forma de impunidade e que seja mais severa do que as penas restritivas de direitos ${ }^{158}$.

Em razão da natureza da suspensão condicional da pena, o condenado não é obrigado a aceitar a substituição, nem as suas condições ${ }^{159}$. Ainda, caso aceite as condições e deixe de cumpri-las, poderá perder o benefício e ter que cumprir a pena privativa de liberdade anteriormente imposta.

O Código Penal previu situações em que se faz necessária a revogação da suspensão condicional da pena concedida, previstas no artigo 81, quais sejam: se o beneficiário, no curso do prazo da suspensão, é condenado, em sentença irrecorrível, por crime doloso, se frustra, embora solvente, a execução da pena de multa ou não efetua, sem motivo justificado, a reparação do dano, ou se descumpre, no primeiro ano do prazo, a prestação de serviços à comunidade ou a limitação de fim de semana.

Há, ademais, situações de revogação facultativa da suspensão condicional da pena, previstas no artigo $81, \S 1^{\circ}$, do Código Penal, ou de prorrogação do prazo da suspensão até o máximo, se este não foi o fixado, conforme artigo $81, \S 3^{\circ}$, que são: o descumprimento, pelo condenado, de qualquer outra condição imposta na concessão do benefício, ou se o beneficiário for condenado, em sentença irrecorrível, por crime culposo ou por contravenção, a pena privativa de liberdade ou restritiva de direitos.

Se o beneficiário estiver sendo processado por outro crime ou contravenção, o prazo da suspensão da pena é prorrogado até o julgamento definitivo do processo.

Por fim, de acordo com o artigo 82, do Código Penal, expirado o prazo da suspensão condicional da pena, sem que tenha havido revogação, considera-se extinta a pena privativa de liberdade.

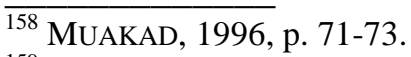

159 ALMEIDA, J., 2003., p. 27.
} 


\subsubsection{Do livramento condicional}

Outra medida que suspende a execução da pena privativa de liberdade é o livramento condicional, que é um ato da execução da pena que liberta o condenado, verificada a existência de seus pressupostos, mas que ainda prolonga o controle penal formal sob a vida do indivíduo ${ }^{160}$.

Conforme o artigo 83, do Código Penal, o livramento condicional pode ser concedido ao condenado a pena privativa de liberdade igual ou superior a 2 (dois) anos, desde que cumprida mais de um terço da pena se o condenado não for reincidente em crime doloso e tiver bons antecedentes. Se o condenado for reincidente em crime doloso, é necessário que cumpra mais da metade da pena; nos casos de condenação por crime hediondo, prática da tortura, tráfico ilícito de entorpecentes e drogas afins e terrorismo, é necessário que cumpra mais de dois terços da pena, desde que não seja reincidente específico em crimes dessa natureza ${ }^{161}$. Deve-se comprovar, ainda, comportamento satisfatório durante a execução da pena, bom desempenho no trabalho que lhe foi atribuído e aptidão para prover à própria subsistência mediante trabalho honesto, e tenha reparado, salvo efetiva impossibilidade de fazê-lo, o dano causado pela infração.

Ainda, conforme o parágrafo único deste artigo, para o condenado por crime doloso, cometido com violência ou grave ameaça à pessoa, a concessão do livramento ficará, também, subordinada à constatação de condições pessoais que façam presumir que o liberado não voltará a delinquir.

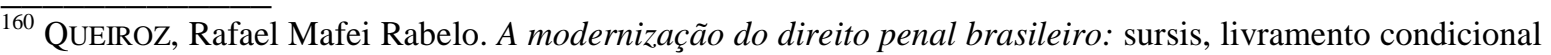
e outras reformas do sistema de penas clássico no Brasil, 1924-1940. São Paulo: Quartier Latin, 2007. p. 258259. Para alguns, a exemplo de KARAM, o livramento condicional é a última etapa do cumprimento da pena privativa de liberdade, consistindo na imposição de medidas restritivas da liberdade que substituem a privação deste direito após o cumprimento de determinado período de encarceramento (KARAM, Maria Lúcia. Disciplina do livramento condicional no ordenamento jurídico-penal brasileiro e violações a direitos fundamentais. In: MARCHI JR, Antônio de Padova; PINTO, Felipe Martins (Coord.); FernandeS, Agostinho; LACERDA, Bruno Amaro (Colab.). Execução penal: constatações, críticas, alternativas e utopias. Curitiba: Juruá, 2008. p. 153).

${ }^{161}$ Há uma lacuna legislativa em relação à concessão de livramento condicional aos réus primários com maus antecedentes. Então, interpretando de forma a favorecer o réu, ainda que com meus antecedentes, deve ser o livramento condicional concedido quando completos, nesses casos, 1/3 (um terço) da pena (SHECAIRA; CORRÊA JR., 2002, p. 354-355).
} 
Apesar do uso do verbo "poder" no artigo 83, do Código Penal, o livramento condicional é um direito subjetivo do condenado, desde que cumpridos os requisitos legais. Assim, deve o juiz buscar na lei os requisitos para a concessão do livramento, não ficando ao seu arbítrio a decisão sobre a concessão dele ${ }^{162}$.

A diferenciação feita para a concessão do livramento condicional para os condenados por determinados crimes ou para os reincidentes específicos indica violação aos princípios da individualização da pena, culpabilidade e isonomia, tendo em vista o tratamento diferenciado feito pelo legislador. O juiz da execução, nestes casos, não pode trazer, para a execução penal, dados que já foram utilizados e só interessavam à instrução processual $^{163}$.

Ademais, reitera-se que a súmula 715, do Supremo Tribunal Federal, determina que o cálculo da pena necessária a ser cumprida para a concessão do livramento é sobre a pena total, e não a unificada. Assim, em comparação com a legislação aplicada em países onde é permitida a pena perpétua, é possível um réu condenado a esta pena obter a liberdade, através do livramento condicional, em menor tempo do que um réu sairia do regime fechado aqui no Brasil ${ }^{164}$.

A sentença que concede o livramento condicional deve especificar as condições a que ficará subordinado o benefício, a teor do artigo 85, do Código Penal.

Conforme o artigo 132, parágrafos $1^{\circ}$ e $2^{\circ}$, da Lei de Execução Penal, serão sempre impostas ao liberado condicional as seguintes obrigações: obter ocupação lícita dentro de prazo razoável se for apto para o trabalho; comunicar periodicamente ao juiz sua ocupação; e não mudar do território da comarca do juízo da execução, sem prévia autorização deste. Poderão, ainda, ser impostas, entre outras, as seguintes obrigações: não mudar de residência sem comunicação ao juiz e à autoridade incumbida da observação cautelar e de proteção; recolher-se à habitação em hora fixada; e não frequentar determinados lugares.

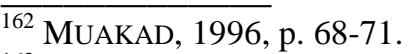

${ }^{163}$ KARAM, 2008, p. 156-161.

164 O livramento condicional deveria ser facilitado para não criar penas perpétuas de fato, que levam as pessoas ao desespero, criando sérios problemas dentro dos estabelecimentos penais (FRAGOSO, 1980-a, p. 1417).
} 
Da mesma forma que a suspensão condicional da pena, o artigo 86, do Código Penal, estabelece que, o livramento condicional será revogado se o liberado for condenado a pena privativa de liberdade, em sentença irrecorrível por crime cometido durante a vigência do benefício ou por crime anterior, observado o disposto no artigo 84, do mesmo código.

Poderá, também, haver revogação, conforme o artigo 87, do Código Penal, se o liberado deixar de cumprir qualquer das obrigações constantes da sentença, ou for irrecorrivelmente condenado, por crime ou contravenção, a pena que não seja privativa de liberdade. Nesse caso, de acordo com o artigo 140, parágrafo único, da Lei de Execução Penal, caso mantido o livramento condicional, o juiz deverá advertir o liberado ou agravar as condições.

Caso ocorra a revogação do livramento, este não poderá ser novamente concedido, e, salvo quando a revogação resulta de condenação por outro crime anterior àquele benefício, não se descontará da pena o tempo em que esteve solto o condenado, como estabelece o artigo 88, do Código Penal.

Se até o seu término o livramento não é revogado, considera-se extinta a pena privativa de liberdade, sendo que o juiz não poderá declarar a extinção da pena, enquanto não transitar em julgado a sentença de processo a que responde o liberado, por crime cometido na vigência do livramento, conforme disposto nos artigos 89 e 90, do Código Penal.

2.2. Da execução da pena privativa de liberdade

Determinada a privação de liberdade como a pena a ser aplicada à pessoa por ter cometido uma infração penal, definida sua quantidade e o regime inicial de cumprimento de pena, e sendo incabível sua substituição por penas restritivas de direitos, ingressa o condenado no sistema penitenciário, ficando sujeito às determinações da Lei Federal $\mathrm{n}^{\mathbf{o}}$ 7.210/84, conhecida como Lei de Execução Penal. 
2.2.1. Lei de Execução Penal (Lei Federal nº 7.210/1984)

A Lei de Execução Penal, que normatizou a jurisdicionalização da pena, estabelece as diretrizes que devem ser seguidas para o cumprimento da pena privativa de liberdade. Logo em seu primeiro artigo, esta lei estabelece que a execução penal tem por objetivo efetivar as disposições da sentença e proporcionar condições para a harmônica integração social do condenado.

Esse conjunto de normas que regulamentam a organização carcerária é autônomo, distinto do Direito Penal e Processual Penal, e regula o ambiente carcerário com base na segurança e disciplina ${ }^{165}$.

Com esta lei, o princípio da legalidade passa a abranger a execução penal, sendo que a margem deixada para o arbítrio da autoridade administrativa deve estar contida nos limites dos regulamentos e das instruções. Isso para impedir que o excesso ou o desvio de finalidade da execução criminal comprometa a dignidade e a humanidade do Direito Penal $^{166}$.

Afinal, o condenado não é encaminhado ao cárcere para ser castigado, pois a natureza aflitiva da pena decorre da própria perda da liberdade de locomoção ${ }^{167}$.

Em dados divulgados em junho de 2014, pelo Conselho Nacional de Justiça, constatou-se que, no Brasil, há 563.526 presos no sistema carcerário brasileiro, sendo que

\footnotetext{
${ }^{165}$ CARVAlho, Salo de. Pena e garantias: a crise do direito e do processo penal / o garantismo jurídico / as teorias da pena / os sistemas de execução / a lei de execução penal / os conflitos carcerários / os direitos (de resistência) dos presos. 2. ed. Rio de Janeiro: Lumen Juris, 2003. p. 168-169.

${ }^{166}$ Com a jurisdicionalização da execução penal, o apenado deixa de ser um mero objeto do processo da execução e passa a ser titular de posição jurídica como sujeito da relação processual, titular de posições jurídicas (Cintra, Antônio Carlos de Araújo; DinAmarco, Cândido Rangel; Grinover, Ada Pellegrini. Teoria geral do processo. $16^{\mathrm{a}}$ ed. São Paulo: Malheiros, 2000. p. 315).

${ }^{167}$ FraGoso, 1980-a, p. 7-8.
} 
o sistema tem apenas 357.219 vagas ${ }^{168}$. Ainda, se somadas as pessoas em prisão domiciliar no Brasil, a população carcerária cresce para 711.463 pessoas.

Além do déficit de 206.307 vagas no sistema prisional, deixando de contar as pessoas que estão em prisão domiciliar, ou de 354.244, contando essas pessoas, é expressivo, também, o número de mandados de prisão em aberto registrado no Banco Nacional de Mandados de Prisão - 373.991 mandados de prisão ainda estão para ser cumpridos.

Essa superpopulação carcerária traz consequências diretas para o sistema prisional e a forma de execução das penas privativas de liberdade, pois há enorme discrepância entre a realidade prisional e a legislação brasileira ${ }^{169}$.

No Brasil, é possível verificar a situação carcerária através de dados e relatórios trazidos por órgãos governamentais, como o Ministério da Justiça e o Conselho Nacional de Justiça, órgãos internacionais, a exemplo da Organização das Nações Unidas e organizações não governamentais.

O Conselho Nacional de Política Criminal e Penitenciária - $\mathrm{CNPCP}^{170}$, órgão subordinado ao Ministério da Justiça, por exemplo, faz visitas periódicas nas instituições

\footnotetext{
${ }^{168}$ Conselho NaCional de JustiçA. Departamento de Monitoramento e Fiscalização do Sistema Carcerário e do Sistema de Execução de Medidas Socioeducativas - DMF. Novo diagnóstico de pessoas presas no Brasil, junho de 2014. Disponível em: http://www.cnj.jus.br/images/imprensa/diagnostico_de_pessoas_presas_correcao.pdf, acesso em 17.08.2014. 169 A superpopulação carcerária é um fenômeno generalizado no Brasil, levando a situações que vão de encontro à dignidade da pessoa presa (Fragoso, Heleno Cláudio. Que Direito?. In: Fragoso, Heleno Cláudio; CATÃO, Yolanda; SÜSSEKIND, Elisabeth. Direitos dos presos. Rio de Janeiro: Forense, 1980. p. 4042).

${ }^{170}$ Prevê o artigo 62 e seguintes, da Lei de Execução Penal, que, ao Conselho Nacional de Política Criminal e Penitenciária, incube propor diretrizes da política criminal quanto à prevenção do delito, administração da Justiça Criminal e execução das penas e das medidas de segurança; contribuir na elaboração de planos nacionais de desenvolvimento, sugerindo as metas e prioridades da política criminal e penitenciária; promover a avaliação periódica do sistema criminal para a sua adequação às necessidades do país; estimular e promover a pesquisa criminológica; elaborar programa nacional penitenciário de formação e aperfeiçoamento do servidor; estabelecer regras sobre a arquitetura e construção de estabelecimentos penais e casas de albergados; estabelecer os critérios para a elaboração da estatística criminal; inspecionar e fiscalizar os estabelecimentos penais, bem assim informar-se, mediante relatórios do Conselho Penitenciário, requisições, visitas ou outros meios, acerca do desenvolvimento da execução penal nos Estados, Territórios e Distrito Federal, propondo às autoridades dela incumbida as medidas necessárias ao seu aprimoramento; representar ao juiz da execução ou à autoridade administrativa para instauração de sindicância ou procedimento administrativo, em caso de
} 
carcerárias de todos os estados brasileiros, apresentando, posteriormente, relatórios descrevendo a situação encontrada nos estabelecimentos ${ }^{171}$.

O Subcomitê de Prevenção da Tortura e outros Tratamentos ou Penas Cruéis, Desumanos ou Degradantes, da Organização das Nações Unidas, visitou algumas instituições do sistema carcerário brasileiro entre 19 e 30 de setembro de 2011, motivo pelo qual foi apresentado, em 08 de fevereiro de 2012, um relatório sobre os fatos constatados e com sugestões para implementação pelos poderes legislativo e executivo ${ }^{172}$.

Da leitura desses relatórios, é possível observar que a Lei de Execução Penal, apesar de extensa e detalhista quanto à execução da pena privativa de liberdade, não consegue alcançar seus objetivos, e suas diretrizes são inobservadas nos estabelecidos penais $^{173}$.

violação das normas referentes à execução penal; e representar à autoridade competente para a interdição, no todo ou em parte, de estabelecimento penal.

${ }^{171}$ Tais relatórios podem ser encontrados em: <http://portal.mj.gov.br/main.asp?ViewID=\%7BE9614C8CC25C-4BF3-A238-98576348F0B6\%7D\&params=itemID=\%7BA5701978-080B-47B7-98B6-

90E484B49285\%7D;\&UIPartUID=\%7B2868BA3C-1C72-4347-BE11-A26F70F4CB26\%7D>， acesso em 17.08.2014.

172 ORGANIZAÇão DAS NAÇÕES UNIDAS, 2012.

${ }^{173}$ No estado de São Paulo, há uma exceção quanto a esta precária situação carcerária, que são os centros de ressocialização, formados a partir de uma parceria entre o estado e a sociedade civil para o gerenciamento da prisão e do trabalho com o preso. Nestes locais, tenta-se, efetivamente, aplicar um tratamento prisional que conduza à reintegração do ofensor à sociedade e que previna a reincidência criminal. São 22 centros, no estado, localizados em cidades menores, com média de 210 presos cada um e administrados por uma organização local. Estes centros obtêm menores taxas de reincidência e custos de operação muito menor que prisões convencionais. Com eles, tenta-se criar uma cultura prisional alternativa, engajando a família e a comunidade, dando oportunidade aos presos para estudar e aprender um ofício e apoio à autoestima, habilidades sociais e perspectivas da vida futura. É feita uma seleção de detentos para estes locais, não sendo aceitos os persistentemente violentos ou que se consideram criminosos de carreira. $\mathrm{O}$ tratamento dado aos presos nestes locais difere das prisões convencionais, por exemplo, pelo chamamento dos presos, que são chamados de "reeducandos", para evitar rótulos que reforçam uma subcultura prisional, e as relações de poder entre os funcionários e reclusos, que são reconfiguradas (MACAULAY, Fiona. Os centros de ressocialização no Estado de São Paulo: Estado e sociedade civil em um novo paradigma de administração prisional e de reitegração de ofensores. Revista de Estudos Criminais, Porto Alegre, v. 7, n. 26, p.63-71, jul./set. 2007). Mais sobre os centros de ressocialização, MATTOs, Renata Soares Bonavides de. Direitos do presidiário e suas violações. São Paulo: Método, 2002. p. 182-198. Nas prisões convencionais, o fortalecimento, por exemplo, dos conselhos da comunidade, previstos no artigo 80, da Lei de Execução Penal, poderia resultar em consequências positivas para a assistência e o tratamento dado aos presos nestes locais, pois, dentre as suas atribuições estão a fiscalização dos presídios e a obtenção de recursos materiais e humanos para melhor assistência ao recluso, conforme o artigo 81, desta lei. 
Por exemplo, no artigo 10, desta lei, é assegurada ao preso assistência prestada pelo Estado - material, à saúde, jurídica, educacional, social e religiosa - com o objetivo de prevenir novos crimes e orientar o retorno do criminoso à convivência em sociedade ${ }^{174}$.

Ocorre que essa assistência, garantida por lei, não é prestada de forma eficaz aos condenados.

O direito dos presos à saúde é comprometido pela falta de recursos financeiros, materiais e humanos. Além disso, a subordinação dos serviços de saúde aos serviços de segurança da instituição não permite um atendimento plenos ao preso, comprometendo, por exemplo, a emissão de laudos de perícia médica em casos de suspeita de tortura ou de maus tratos, pois o médico não tem privacidade para examinar o preso, tendo sempre a presença de seguranças ou policiais da instituição presente ${ }^{175}$.

Há presídios em que um médico é responsável pelo atendimento de 3.000 presos, apenas uma vez por semana, o que leva a situações de doenças crônicas graves e membros quebrados e ferimentos sem tratamento. Quando solicitada assistência médica, ainda, os presos podem sofrer punição ou maus tratos no percurso até o hospital ${ }^{176}$.

A assistência jurídica gratuita não alcança a todos que dela necessitam, impedindo uma defesa plena dos direitos da pessoa presa ${ }^{177}$. No Estado de São Paulo, o atendimento jurídico aos presos, na maioria das vezes, é prestado por advogados fornecidos pela

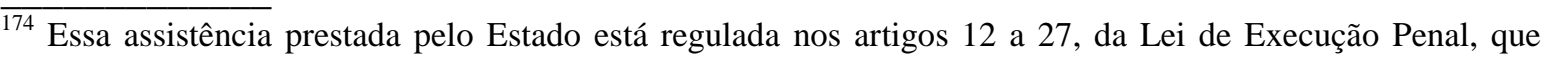
garantem ao preso, entre outras coisas, alimentação, vestuários, instalações higiênicas, atendimento médico, farmacêutico e odontológico, assistência jurídica gratuita àqueles que não possuem recursos financeiros para constituir advogado, instrução escolar, formação profissional do preso, amparo e preparação para o retorno à liberdade, liberdade de culto, bem como local apropriado para a realização deste. Ao egresso é assegurado, conforme o artigo 25, da mesma lei, orientação e apoio para reintegrá-lo à vida em liberdade e concessão, se necessário, de alojamento e alimentação, em estabelecimento adequado, pelo prazo de 2 (dois) meses, podendo esse prazo ser prorrogado, uma única vez, comprovado, por declaração do assistente social, o empenho na obtenção de emprego.

${ }^{175}$ Em casos de atendimento médico ao preso, deveria ser seguido o Protocolo de Istambul, das Nações Unidas, que determina, em seu parágrafo 123 , que todos os detidos devem ser examinados em privado (ORGANIZAÇÃO DAS NAÇÕES UNIDAS, 2012, p. 8-9).

${ }_{176}$ ORGANIZAÇão DAS NAÇÕES UNIDAS, op. cit., p. 9-10.

${ }^{177}$ Ibid., p. 6.
} 
Fundação Prof. Dr. Manoel Pedro Pimentel - FUNAP ${ }^{178}$, que fazem atendimento dentro dos estabelecimentos prisionais ${ }^{179}$. A Defensoria Pública não tem estrutura para atender dentro de todos os locais destinados ao cumprimento da pena privativa de liberdade ${ }^{180}$.

A alimentação presente nos estabelecimentos penais, além de ser, muitas vezes, mal preparada, ainda é objeto de comércio ilegal dentro dos estabelecimentos prisionais, aonde os presos podem só ter acesso à alimentação se pagar por ela ${ }^{181}$.

Assim, os presos são vítimas de violações de direitos humanos em decorrências da superlotação, consequência do crescimento do encarceramento no país, da falta de assistência médica, bem como pelo uso de violência e tortura pelos guardas, más condições de higiene, entre outras situações a que são submetidos ${ }^{182}$.

A partir do artigo 82, a Lei de Execução Penal estabelece o modelo ao qual os estabelecimentos penais devem seguir.

No artigo 83, determina-se que o estabelecimento penal, conforme a sua natureza, deverá contar em suas dependências com áreas e serviços destinados a dar assistência, educação, trabalho, recreação e prática esportiva aos detentos. Ainda, os estabelecimentos penais destinados a mulheres serão dotados de berçário, onde as condenadas possam cuidar de seus filhos, inclusive amamentá-los, no mínimo, até 6 (seis) meses de idade.

\footnotetext{
${ }^{178}$ A FUNAP, instituída pelo Decreto $\mathrm{n}^{\mathrm{o}}$ 10.235/77, tem o objetivo de promover a reintegração social dos presos através do fornecimento de educação, cultura, saúde, trabalho, entre outras coisas, a eles.

${ }^{179}$ BRASIL. Ministério DA JustiçA. Conselho Nacional de Política Criminal e Penitenciária. Relatório sobre inspeção em estabelecimentos penais do estado de São Paulo, julho de 2011. p. 3, 5-6 e 18. Disponível em: $<$ http://portal.mj.gov.br/services/DocumentManagement/FileDownload.EZTSvc.asp?DocumentID $=\{0 B C 48 \mathrm{~F}$ B8-0E4C-4C85-9770-21333D4C13F9 $\} \&$ ServiceInstUID $=\{4$ AB01622-7C49-420B-9F76-15A4137F1CCD $\}>$, acesso em 17.08.2014.

${ }^{180} \mathrm{Na}$ última visita da Organização das Nações Unidas com o objetivo de averiguar o sistema carcerário brasileiro, entre 18 e 28 de março de 2013, cujo relatório ainda não foi publicado, os membros do Grupo de Trabalho sobre Detenção Arbitrária destacaram fatos que se repetiram nesta visita. Foi constatado que os defensores públicos não conseguem ser eficientes para realizar seus trabalhos, pois há sobrecarga dele, tendo em vista o número elevado de presos e o número restrito de defensores (Disponível em: $<$ http://www.onu.org.br/grupo-de-trabalho-sobre-detencao-arbitraria-declaracao-apos-a-conclusao-de-suavisita-ao-brasil-18-a-28-marco-de-2013/>, acesso em 17.08.2014).

${ }^{181}$ Situação, relatada pelo jornal Folha de São Paulo, em 11.10.1992, p. 4.3, que acontecia na antiga Casa de Detenção de São Paulo.

${ }^{182}$ CARVAlHo, Salo de; FreIRE, Christiane Russomano. O regime disciplinar diferenciado: notas críticas à reforma do sistema punitivo brasileiro. Revista Transdisciplinar de Ciências Penitenciárias, Pelotas, v. 4, n. 1, p. 10-13, jan./dez. 2005.
} 
Devem, também, ser instaladas salas de aulas destinadas a cursos do ensino básico e profissionalizante.

Conforme os relatórios citados, a educação é regularmente fornecida nos presídios, em classes de alfabetização, dos dois ciclos do ensino fundamental, de ensino médio e de ensino profissionalizante. Há presos, ainda, que cursam o ensino superior. Contudo, no estado de São Paulo, por exemplo, aulas são ministradas pelos próprios presos, como nas penitenciárias "Cabo PM Marcelo Pires da Silva”, em Itaí e "Wellington Rodrigo Segura", conhecida como "Presidente Prudente I", o que pode comprometer a qualidade do curso ${ }^{183}$.

Em relação à separação dos presos, o artigo 84, da Lei de Execução Penal, estabelece que o preso provisório deve ficar separado do condenado por sentença transitada em julgado, o preso primário deve cumprir pena em seção distinta daquela reservada para os reincidentes, e o preso que, ao tempo do fato, era funcionário da administração da justiça criminal deve ficar em dependência separada.

Na prática, não é isto o que ocorre. Não é respeitada a separação de presos processados e condenados, nem a transferência de presos para o local adequado em tempo razoável, ficando os presos que ainda estão sendo acusados por longo período de tempo em delegacias $^{184}$.

De acordo com os dados apresentados pelo CNPCP, no estado de São Paulo, na Cadeia Pública de Batatais, local destinado a presos provisórios, foram encontrados presos já condenados. Da mesma forma, na Cadeia Pública de Franca - Feminina, havia 40 mulheres já condenadas no local, dos regimes fechado e semiaberto aguardando a transferência para o local apropriado. Ainda, na Penitenciária de Ribeirão Preto, havia 4 presos com medida de segurança já decretada, mas que ainda aguardavam a transferência

\footnotetext{
$\overline{183}$ BRASIL. MINISTÉRIO DA JUSTIÇA, 2011, p. 22-26.

${ }^{184}$ ORGANIZAÇÃO DAS NAÇÕES UNIDAS, 2012, p. 15.
} 
de local; e, na Cadeia Pública de Osasco, além dos presos provisórios, havia, também, presos devedores de alimentos ${ }^{185}$.

Apesar dos requisitos objetivos que a lei estabelece, os presos também são separados por alas dependendo da facção criminosa a qual pertencem, presentes em quase todos os locais visitados pelos membros do Subcomitê da ONU ${ }^{186}$. Realizada a separação desta maneira, os detentos que não fazem parte de qualquer facção criminosa podem ser forçados a integrar uma delas, o que promove, posteriormente, prática de novos crimes.

A lotação do estabelecimento penal deve ser compatível com sua estrutura e finalidade, conforme determina o artigo 85, da Lei de Execução Penal, cabendo ao CNPCP determinar o limite máximo de capacidade do estabelecimento, atendendo a sua natureza e peculiaridades.

Contudo, a superpopulação carcerária é a realidade em nosso sistema, que, como visto acima, tem déficit de mais de 200 mil vagas. O Subcomitê da ONU salientou que a superlotação extrema, como no caso relatado de 20 homens em uma cela de $8 \mathrm{~m}^{2}$, é uma forma severa de maus tratos, devendo ser respeitado um espaço mínimo por detento ${ }^{187}$.

No estado de São Paulo, são facilmente encontradas instituições com este fenômeno, conforme os dados apresentados pelo CNPCP e conforme dados existentes no site da Secretaria de Administração Penitenciária ${ }^{188}$. Na Cadeia Pública de Batatais, havia o dobro de presos além do permitido no local; no Centro de Detenção Provisória Belém I, havia 2.200 presos para 768 vagas; e, em Belém II, 1.493 presos para 468 vagas, sendo que desses 584 já estavam condenados ${ }^{189}$.

A Lei de Execução Penal também especifica os estabelecimentos penais, conforme a necessidade de cada regime de cumprimento de pena privativa de liberdade.

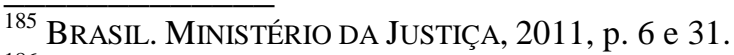

186 ORGANIZAÇÃO DAS NAÇÕES UNIDAS, 2012, p. 18.

${ }^{187}$ Ibid., p. 15-17.

${ }^{188}$ Informações sobre as unidades prisionais do estado de São Paulo, bem como a ocupação de cada uma delas, podem ser encontradas em: <http://www.sap.sp.gov.br/uni-prisionais/pen.html〉, acesso em 17.08.2014. ${ }^{189}$ BRASIL. MINISTÉRIO DA JUSTIÇA, op. cit., p. 2, 7-8.
} 
O primeiro estabelecimento - a penitenciária - é descrito a partir do artigo 87, desta lei, e destina-se ao condenado à pena de reclusão, em regime fechado.

De acordo com a Lei de Execução Penal, neste local, o condenado será alojado em cela individual que conterá dormitório, aparelho sanitário e lavatório, sendo os requisitos básicos da unidade celular a salubridade do ambiente pela concorrência dos fatores de aeração, insolação e condicionamento térmico adequado à existência humana, e área mínima de $6,00 \mathrm{~m}^{2}$ (seis metros quadrados).

Ademais, a penitenciária de mulheres será dotada de seção para gestante e parturiente e de creche para abrigar crianças maiores de 6 (seis) meses e menores de 7 (sete) anos, com a finalidade de assistir a criança desamparada cuja responsável estiver presa. Essa seção e a creche devem ter, no mínimo, atendimento por pessoal qualificado e horário de funcionamento que garanta a melhor assistência à criança e a sua responsável.

Já a penitenciária de homens deve ser construída, em local afastado do centro urbano, à distância que não restrinja a visitação aos presos.

Apesar de a arquitetura dada pela lei, além da superlotação do sistema, são facilmente encontradas celas em mau estado, sujas e abafadas, com condições sanitárias precárias ou inexistentes. Camas também são inadequadas ou inexistentes, havendo até revezamento entre os presos para dormir, além da falta de comida, água e acesso a ar fresco.

Falta de iluminação e ventilação e altas temperaturas podem ser encontradas em vários estabelecimentos pelo país, sendo a situação mais agravada nas celas utilizadas para castigo. A superlotação dos presídios, aliada a esses fatores, tornam as celas insalubres 
devido à falta de ar e aos odores nocivos, aumentando, ainda, o risco de transmissão de doenças infectocontagiosas, como a tuberculose ${ }^{190}$.

Há presídios com esgoto vazando nas celas, infestação de insetos, fornecimento de sabonete e papel higiênico mediante pagamento e banheiros dispostos de modo que os presos têm pouca privacidade ${ }^{191}$.

A Cadeia Pública de Batatais se encontrava em péssimo estado quando houve a visita do CNPCP, e, no Centro de Detenção Provisória de Pinheiros I, havia falta de produtos de higiene pessoal. No Centro de Detenção Provisória de Bauru, não havia cama para todos os presos, e, na Penitenciária de Itaí, nas celas destinadas para os presos em tratamento de saúde, o banho só era feito em chuveiro com água quente quando havia recomendação médica ${ }^{192}$.

Contrariando a Lei de Execução Penal, foram encontrados presídios, como, por exemplo, o Nelson Hungria, em Minas Gerais, que, ao invés de celas individuais, adotavam dormitórios com até 50 leitos para os detentos ${ }^{193}$. No Estado de São Paulo, as únicas instituições que adotam celas individuais para todos os presos, dentre as que foram visitadas pelo CNPCP, são a Penitenciária "Dr. Paulo Luciano de Campo", conhecida como “Avaré I", e a "Dr. José Ismael Pedrosa”, em Presidente Bernardes, destinada para presos colocados no Regime Disciplinar Diferenciado ${ }^{194}$.

Destinada ao cumprimento da pena privativa de liberdade em regime semiaberto, a colônia agrícola, industrial ou similar é estabelecida a partir do artigo 91, da Lei de Execução Penal.

\footnotetext{
${ }^{190}$ FERNANDES, Newton. A falência do sistema prisional brasileiro. São Paulo: RG Editores, 2000. p. 201202.

191 ORGANIZAÇão DAS NAÇÕES UNIDAS, 2012, p. 19-21.

192 BRASIL. MINISTÉRIO DA JUSTIÇA, 2011, p. 23.

193 ORGANIZAÇÃO DAS NAÇÕES UNIDAS, op. cit., p. 20

${ }^{194}$ BRASIL. MINISTÉRIO DA JUSTIÇA, op . cit., p. 23.

${ }^{194}$ ORGANIZAÇÃO DAS NAÇÕES UNIDAS, op. cit., p. 21-22 e 27-28.
} 
Neste estabelecimento, o condenado poderá ser alojado em compartimento coletivo, observada a salubridade do ambiente pela concorrência dos fatores de aeração, insolação e condicionamento térmico adequado à existência humana. Essas dependências coletivas têm como requisitos básicos a seleção adequada dos presos e o limite de capacidade máxima que atenda aos objetivos de individualização da pena.

Apesar dos distintos estabelecimentos para o cumprimento da pena privativa de liberdade nos regimes fechado e semiaberto, a separação de presos por regime também não é respeitada. No Centro de Detenção Provisória de Pinheiros I, um preso espera até 2 meses para a mudança do regime fechado para o semiaberto após a progressão e, na Penitenciária de Presidente Prudente I, os presos dos regimes fechado e semiaberto ficam juntos. Em relação à estrutura física do local, na Penitenciária “Alberto Brocchieri”, conhecida como Bauru I, local destinado a abrigar presos do regime semiaberto, constatouse que esta era assemelhada à do regime fechado ${ }^{195}$.

Em relação ao trabalho no regime semiaberto, na ala de progressão da Penitenciária de Belém I, dos 204 presos no regime semiaberto, apenas 60 deles trabalhavam externamente. Na penitenciária "Alberto Brocchieri”, ou Bauru I, e no Instituto Penal Agrícola "Prof. Noé Azevedo", os presos em trabalho externo eram monitorados eletronicamente $^{196}$, sendo que nesta última instituição, foram relatados problemas frequentes com evasão de presos, em razão das características físicas do local ${ }^{197}$.

\footnotetext{
$\overline{195}$ BRASIL. MINISTÉRIO DA JUSTIÇA, 2011, p. 23.

195 ORGANIZAÇÃO DAS NAÇÕES UNIDAS, 2012, p. 9, 20 e 24.

196 O monitoramento eletrônico é um recurso material que possibilita uma melhor fiscalização do cumprimento da pena, ou seja, não é uma nova espécie de pena. Ele controla o recluso que está fora das dependências carcerárias, possibilitando a ele resgatar sua dignidade através do trabalho e do convívio social. A aplicação do monitoramento eletrônico aos condenados do regime semiaberto que trabalham externamente à prisão permite a dispensa de obstáculos físicos para a vigilância e contra a fuga, tornando o ambiente prisional muito mais próximo da vida comum (LIMA, Carlos Daniel Vaz. Novas tecnologias na humanização da pena, abr. 2008, artigo digital disponível em <http://carlosdaniel.net/?p=4>, acesso em 15.08.2014). No entanto, para que se respeite o princípio da humanidade das penas, sua utilização deve respeitar a dignidade da pessoa. Assim, por exemplo, o dispositivo utilizado não poderá ser ostensivo ou visível aos demais cidadãos, senão a medida viola a imagem e a honra do condenado, atingindo desnecessariamente esfera de direitos não prevista pelo legislador, o que é, ainda, inútil para os fins propostos (BOTTINI, 2008, p. 172).

${ }^{197}$ BRASIL. MinisTÉRIO DA JUSTIÇA, op. cit., p. 23.
} 
A partir do artigo 93, da Lei de Execução Penal, é descrita a casa de albergado, destinada ao cumprimento da pena privativa de liberdade, em regime aberto, e da pena de limitação de fim de semana.

Este estabelecimento deve situar-se em centro urbano, separado dos demais estabelecimentos, e caracterizar-se pela ausência de obstáculos físicos contra a fuga. Em cada região deve haver, pelo menos, uma casa de albergado, a qual deverá conter, além dos aposentos para acomodar os presos, local adequado para cursos e palestras, e instalações para os serviços de fiscalização e orientação dos condenados.

No entanto, é escasso este tipo de estabelecimento no país, sendo a pena privativa de liberdade em regime aberto cumprida, prioritariamente, em prisão albergue domiciliar.

A falta de vagas no regime semiaberto e a inexistência de locais adequados para o cumprimento da pena privativa de liberdade em regime aberto fazem com que os condenados cumpram sua pena praticamente toda em regime fechado, saindo, da prisão, direto para a rua, sem oportunidade de ser orientado e motivado a desenvolver seu autocontrole e senso de responsabilidade ${ }^{198}$.

Por fim, a cadeia pública, que é destinada ao recolhimento de presos provisórios, é prevista nos artigos 102 e seguintes, da Lei de Execução Penal.

Cada comarca deve ter, pelo menos, 1 (uma) cadeia pública, a fim de resguardar o interesse da Administração da Justiça Criminal e a permanência do preso em local próximo ao seu meio social e familiar. Este estabelecimento deve ser instalado próximo de centro urbano, observando-se, na construção, as mesmas exigências feitas para as penitenciárias, tais como o alojamento em cela individual, que conterá dormitório, aparelho sanitário e lavatório; a salubridade do ambiente pela concorrência dos fatores de aeração, insolação e condicionamento térmico adequado à existência humana, e área mínima de $6,00 \mathrm{~m}^{2}$ (seis metros quadrados).

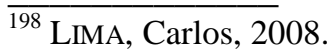


A respeito da cadeia pública, reiteram-se os mesmos apontamentos feitos para os demais estabelecimentos penitenciários no tocante à estrutura física do local. Ademais, como já relatado, a separação de presos provisórios dos condenados não é respeitada, permanecendo nestes locais, também, pessoas com sentença criminal transitada em julgado.

Necessário observar que, apesar do direito constitucional de ter sua integridade física e moral preservada, e da reiteração deste direito pelo artigo 40, da Lei de Execução Penal, a estrutura carcerária brasileira não protege os detentos contra tortura e maus tratos, havendo falhas quanto a esta prevenção deste a entrada do preso no sistema prisional $^{199}$.

Neste ponto, o Subcomitê da ONU ressaltou a necessidade do país ter tolerância zero em relação a estas práticas e que não deveria ser a própria polícia a investigar atos de tortura para preservar a imparcialidade da investigação. Os ouvidores e corregedores deveriam, também, atuar com mais independência ${ }^{200}$.

Os membros do órgão da ONU ressaltaram que, quando diante da autoridade judicial, esta não pergunta aos presos a respeito do tratamento que estes têm recebido na prisão, nem se foi vítima de tortura, sendo que eles deveriam, também, fiscalizar esses fatos $^{201}$.

Essa realidade faz com que o cárcere seja foco de inúmeros problemas, produzindo nefastos efeitos de despersonalização, aculturação prisional e prisionização, resultando na dessocialização do preso. A prisão cria um espaço de anormalidade e violência, onde o

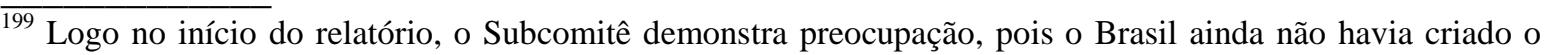
Mecanismo Nacional de Prevenção, previsto na Convenção contra Tortura e Outros Tratamentos ou Penas Cruéis, Desumanos ou Degradantes, ratificada pelo Brasil. Contudo, este mecanismo é hoje objeto da Lei Federal no 12.847/2013, já em vigor. Alguns Estados, como Paraíba, Alagoas e Rio de Janeiro, criaram alguns mecanismos preventivos estaduais, mas, a exemplo do que ocorre no último estado, em que o mecanismo já foi implementado, a eficácia deste órgão é comprometida pela falta de recursos materiais (ORGANIZAÇÃo DAS NAÇÕES UNIDAS, 2012, p. 4-6).

200 ORGANIZAÇão DAS NAÇÕES UNIDAS, op. cit., p. 11-12.

${ }^{201}$ Ibid., p. 7, 19-20.
} 
preso é privado dos direitos inerentes à condição humana, e é inserido num ambiente insalubre e deteriorante ${ }^{202}$.

No estado de São Paulo, juízes, promotores e defensores públicos fazem visitas regulares aos presídios para verificar as condições a que estão submetidos os presos. Em geral, os presídios recebem a visita de juízes e promotores uma vez ao mês e dos defensores, uma vez a cada dois meses ${ }^{203}$.

Essas visitas são importantes para impedir abusos e excessos cometidos pelos agentes penitenciários, certificar a regularidade do processo executório e assegurar o respeito às garantias constitucionais e a plena efetividade das assistências devidas às pessoas do apenado durante a execução da pena privativa de liberdade. Contudo, para que esses fins sejam atingidos, é necessário que estes órgãos adotem as medidas necessárias decorrente da atividade fiscalizadora ${ }^{204}$.

De acordo com o constatado pelo Subcomitê, confissões obtidas por meio ilícito têm sido utilizadas em procedimentos judiciais. Foi relatada a ocorrência de confissão mediante asfixia, choques elétricos, ameaça psicológica e banhos frios ${ }^{205}$.

Foram, ainda, relatados, para o Subcomitê, ocorrência de tortura e maus tratos, como abusos, insultos, sanções arbitrárias, humilhações, havendo espancamentos sobretudo nos momentos que a pessoa está sob custódia policial ou no momento da prisão, de forma gratuita, como punição, com o objetivo de extrair confissões ou como meio de extorsão.

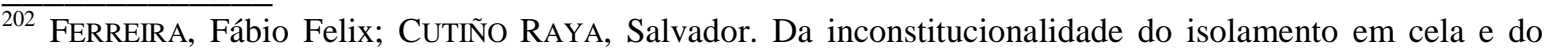
regime disciplinar diferenciado. Revista Brasileira de Ciências Criminais, São Paulo, v. 12, n. 49, p. 259-262, jul./ago. 2004.

${ }^{203}$ BRASIL. MINISTÉRIO DA JUSTIÇA, 2011, p. 4, 18, 20-21 e 27.

${ }^{204}$ MARChI JR, Antônio de Padova. Da importância da fiscalização permanente e das visitas mensais aos estabelecimentos prisionais. In: MARCHI JR, Antônio de Padova; PINTO, Felipe Martins (Coord.); FERNANDES, Agostinho; LACERDA, Bruno Amaro (Colab.). Execução penal: constatações, críticas, alternativas e utopias. Curitiba: Juruá, 2008. p. 309, 313-314.

${ }^{205}$ ORGANIZAÇÃO DAS NAÇÕES UNIDAS, 2012, p. 7, 16-17.
} 
Também foi relatado uso de spray de pimenta e gás lacrimogênio em ambientes fechados, como em celas e carros utilizados para o transporte dos presos, o que pode acarretar risco à saúde e sofrimento desnecessário ${ }^{206}$.

Verificou-se, ainda, a ocorrência de retaliações em casos de presos que fazem queixas dentro das instituições penitenciárias, sendo que estas não são sequer respondidas pelas autoridades competentes ${ }^{207}$.

Foi constatado também pelo Subcomitê que o crime organizado tem controle quase completo de certas instituições, o que dificulta a administração dos locais ${ }^{208}$.

Nestes casos, a autoridade das instituições carcerárias é transferida para gangues ou outros grupos.

Em relação ao direito à vida, que deveria ser assegurado aos presos, o Subcomitê destacou que só no Rio de Janeiro, por exemplo, haviam ocorrido 91 mortes de detentos desde o início de 2011 até a visita deles em setembro do mesmo ano. No presídio Ary Franco ocorreram 7 mortes, sendo que nos registros não estava determinada a causa delas. As situações constatadas nesse presídio equivaliam, conforme o relatório apresentado, a tratamento desumano e degradante ${ }^{209}$.

Todas essas características da realidade do cárcere, além das que são inerentes a ele, contribuem com o processo de modificação, pelo detento, das concepções que tem a seu respeito e a respeito das pessoas que são significativas para ele. O recluso perde o

\footnotetext{
$\overline{206}$ ORGANIZAÇÃO DAS NAÇÕES UNIDAS, 2012, p. 24.

207 Deveria ser garantido aos reclusos o direito de apresentar requerimentos ou queixas ao diretor do estabelecimento ou ao funcionário autorizado a representa-lo, que deveriam ser respondidos sem demora, salvo se fosse manifestamente inconsistente ou desprovido de fundamento, a teor do artigo 36, das Regras Mínimas para o Tratamento dos Reclusos. Estas regras, adotadas pelo primeiro Congresso das Nações Unidas sobre a Prevenção do Crime e o Tratamento dos Delinquentes, em 1955, dispõem sobre os princípios e regras de uma boa organização penitenciária e sobre as práticas relativas ao tratamento dos reclusos.

${ }^{208}$ ORGANIZAÇÃO DAS NAÇÕES UNIDAS, op. cit., p. 12.

${ }^{209}$ Ibid., p. 18. No Brasil, é comum a ocorrência de mortes dentro dos presídios, em especial as causadas pelos próprios detentos, haja vista não ser disponibilizada a segurança necessária dentro dos estabelecimentos penais para resguardar a vida e a integridade física dos detentos, como é possível verificar nesta reportagem: <http://www1.folha.uol.com.br/cotidiano/2014/07/1480064-tres-detentos-morrem-em-dois-dias-em-pedrinhasno-maranhao.shtml>, acesso em 17.08.2014.
} 
papel que ocupava na sociedade e passa a ser codificado como um objeto, que nunca está sozinho, que não toma decisões, que não é mais responsável por si mesmo, e que tem a vida minuciosamente regulamentada, numa rede de coerção, que lhe retira a autonomia e liberdade de ação ${ }^{210}$.

Essa desorganização da personalidade causa o processo de prisionização, em que o recluso adere ao poder informal e à cultura paralela existente na prisão, que tem como efeitos a perda da identidade e a aquisição de uma nova, sentimento de inferioridade, empobrecimento psíquico, infantilização, regressão ${ }^{211}$.

Assim, para que a prisão não promova a degradação, cujas consequências podem ser profundamente drásticas para a mente e a vida do condenado, inclusive na sua relação com a sociedade, é necessário resolver os problemas do cárcere decorrentes da má gestão, falta de interesse político, inabilidade administrativa e técnica e tentar minimizar os problemas que são inerentes à própria natureza da prisão, como o isolamento do preso em relação a sua família, a sua segregação em relação à sociedade, a convivência forçada no meio delinquente, o sistema de poder dentro da prisão, entre outros ${ }^{212}$.

\subsubsection{Dos direitos e deveres dos presos}

Conforme o artigo 38, do Código Penal, e artigo 40, da Lei de Execução Penal, o preso conserva todos os direitos não atingidos pela perda da liberdade, devendo, todas as autoridades, respeitar a integridade física e moral dos presos.

Além disso, o preso tem direito a alimentação suficiente e vestuário; atribuição de trabalho e sua remuneração; Previdência Social; constituição de pecúlio; proporcionalidade na distribuição do tempo para o trabalho, o descanso e a recreação; exercício das atividades

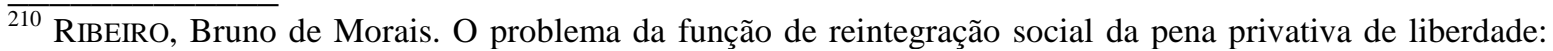
uma análise à luz dos efeitos do sistema social da prisão sobre o indivíduo. In: LIMA, Marcellus Polastri; RIBEIRO, Bruno de Morais (Coord.). Estudos criminais em homenagem a Weber Martins Batista. Rio de Janeiro: Lumen Juris, 2008. p. 40-45.

${ }^{211}$ SÁ, Alvino Augusto de. Criminologia clínica e psicologia criminal. São Paulo: Revista dos Tribunais, 2007. p. 114-116.

${ }_{212}$ Ibid., p. 111-114.
} 
profissionais, intelectuais, artísticas e desportivas anteriores, desde que compatíveis com a execução da pena; assistência material, à saúde, jurídica, educacional, social e religiosa; proteção contra qualquer forma de sensacionalismo; entrevista pessoal e reservada com o advogado; visita do cônjuge, da companheira, de parentes e amigos em dias determinados; chamamento nominal; igualdade de tratamento salvo quanto às exigências da individualização da pena; audiência especial com o diretor do estabelecimento; representação e petição a qualquer autoridade, em defesa de direito; contato com o mundo exterior por meio de correspondência escrita, da leitura e de outros meios de informação que não comprometam a moral e os bons costumes; atestado de pena a cumprir, emitido anualmente, sob pena da responsabilidade da autoridade judiciária competente, de acordo com o artigo 41, da Lei de Execuções Penais.

De acordo com o parágrafo único deste artigo, apenas os direitos à proporcionalidade na distribuição do tempo para o trabalho, o descanso e a recreação, visita do cônjuge, da companheira, de parentes e amigos em dias determinados e contato com o mundo exterior por meio de correspondência escrita, da leitura e de outros meios de informação que não comprometam a moral e os bons costumes poderão ser suspensos ou restringidos mediante ato motivado do diretor do estabelecimento.

Contudo, apesar desse rol extenso de direitos previstos em lei, as autoridades penitenciárias não o respeitam ou não o asseguram de forma plena.

Por exemplo, não são todos os detentos que têm acesso a uma hora de exercícios e banho de sol, nem a educação e trabalho. Em alguns locais, devido ao excesso de presos por cela, há um rodízio onde apenas uma parte dos detentos participa dessas atividades por $\operatorname{dia}^{213}$.

O acesso a cartas e telefonemas também não é pleno, havendo censura e interceptação das correspondências. Apesar de o sigilo às correspondências ser inviolável, conforme o artigo $5^{\circ}$, inciso XII, da Constituição Federal, e a comunicação com o mundo exterior ser condição de saúde mental dos presos, a censura à correspondência e

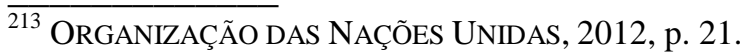


publicações é alvo de atrito dentro dos estabelecimentos penais, pois esta faz parte do sistema de vigilância destas instituições ${ }^{214}$.

Quanto às visitas, estas passam por procedimentos de revista intrusivos e humilhantes, que não obedecem à necessidade, razoabilidade e proporcionalidade. $\mathrm{Na}$ Penitenciária de Franca, por exemplo, as visitas passam pelos procedimentos de revista conhecidos como "banquinho" e "agachamento"215, para verificar se não trazem objetos proibidos, para dentro das prisões, em suas partes íntimas ${ }^{216}$.

As visitas, que deveriam ser incentivadas para que o preso mantenha e fortaleça seus laços familiares, acabam sendo constrangidas quando entram no estabelecimento penal através de revistas constrangedoras, que poderiam ser substituídas por equipamentos tecnológicos ${ }^{217}$.

As visitas íntimas, cuja falta pode provocar desequilíbrio da pessoa, favorecendo condutas inadequadas e gerando tensão nos estabelecimentos prisionais, também deveriam receber a atenção adequada, devendo a administração carcerária fornecer o local adequado e privado para a realização dessas visitas ${ }^{218}$.

Quanto aos deveres, além das obrigações legais inerentes ao seu estado, cumpre ao condenado submeter-se às normas de execução da pena, conforme determina o artigo 38, da Lei de Execução Penal.

\footnotetext{
${ }^{214}$ FrAGOSO, 1980-b, p. 39-40.

215 BRASIL. MinistÉRIO DA JUSTIÇA, 2011, p. 3. Tais técnicas podem desestimular as visitas de manterem contato com seus familiares que se encontram presos, pois elas são estigmatizadas e tratadas desumanamente pelos funcionários do estabelecimento penal (MACAULAY, 2007., p.71-74).

${ }^{216}$ No estado de São Paulo, entrou em vigor a Lei Estadual $\mathrm{n}^{\circ} 15.552 / 2014$, que pró́be os estabelecimentos prisionais de realizar de revistas íntimas nos visitantes. De acordo com a legislação, os visitantes devem ser submetidos a revista mecânica, a qual deverá ser executada em local reservado, por meio de equipamentos capazes de garantir a segurança do estabelecimento prisionais, tais como scanners corporais, detectores de metais, aparelhos de raio-X, ou outras tecnologias que preservem a integridade física, psicológica e moral do visitante revistado.

${ }^{217}$ MATTOS, 2002. p. 75-76.

${ }^{218}$ Situação degradante verificou-se, por exemplo, na antiga Casa de Detenção de São Paulo, em que presos formavam um círculo humano para ocultar outros presos que estavam tendo relações sexuais com suas visitas no pátio da instituição, em razão da falta de local adequado (ANTONINI, José Roberto. Uma experiência democrática na administração penitenciária. Revista dos Tribunais, São Paulo, ano 79, n. 657, p. 388 , jul. 1990).
} 
São deveres dos condenados, inscritos nos artigo 39, desta lei: comportamento disciplinado e cumprimento fiel da sentença; obediência ao servidor e respeito a qualquer pessoa com quem deva relacionar-se; urbanidade e respeito no trato com os demais condenados; conduta oposta aos movimentos individuais ou coletivos de fuga ou de subversão à ordem ou à disciplina; execução do trabalho, das tarefas e das ordens recebidas; submissão à sanção disciplinar imposta; indenização à vitima ou aos seus sucessores; indenização ao Estado, quando possível, das despesas realizadas com a sua manutenção, mediante desconto proporcional da remuneração do trabalho; higiene pessoal e asseio da cela ou alojamento; e conservação dos objetos de uso pessoal.

\subsubsection{Trabalho e remição}

Diferentemente de quando as penas tinham caráter meramente retributivo e o trabalho fazia parte do castigo a que o preso estava submetido, que era caracterizado pela penosidade e gratuidade, sem utilidade para o preso, que estava pagando uma dívida com a sociedade pelos danos causados, sendo simplesmente um meios de expiação e dissuasão dos crimes $^{219}$, o trabalho do preso é regulamentado na Lei de Execução Penal, a partir do artigo 28 , que estabelece que a atividade laborativa, como dever social e condição de dignidade humana, terá a finalidade educativa, com a formação profissional do condenado, e produtiva, devendo ser aplicadas à organização e aos métodos de trabalho as precauções relativas à segurança e à higiene.

Conforme o artigo 41, da Lei de Execução Penal, o trabalho é um direito do preso $^{220}$. Sendo parte da função ressocializadora que se atribui à prisão, tem por objetivo que o preso desenvolva atividade de forma útil e rendosa, proporcionando sustento próprio e auxílio à família, mantendo-o, desta forma, ligado ao papel familiar atribuído ao homem

\footnotetext{
${ }^{219}$ BRANT, Vinícius Caldeira. O trabalho encarcerado. Forense: Rio de Janeiro, 1994. p. 107-111.

${ }^{220}$ SHECAIRA; CORRÊA JR., 2002, p. 336-337. Antes da promulgação da Constituição Federal de 1988 e da vigência da Lei de Execução Penal, o trabalho do preso era considerado uma obrigação, atuando no tratamento do recluso (FRAGOSO, 1980-b, p. 31-33).
} 
livre. Ainda, o aprendizado e experiência das atividades desenvolvidas deveriam proporcionar oportunidades de emprego ao sair da prisão ${ }^{221}$.

O trabalho também pode ser um privilégio para os presos, pois os aproximam daqueles que dirigem o estabelecimento prisional, abrindo maiores oportunidades de comunicação com o mundo exterior, passam a ser vistos como presos "em recuperação" e ajudam a família, cujo sustento depende do preso $^{222}$.

Entretanto, não são todos os presos que trabalham. No estado de São Paulo, quase todas as instituições fornecem essa atividade aos presos, mas nem sempre há vagas disponíveis para todos ${ }^{223}$.

O artigo 39, do Código Penal, garante aos presos a remuneração pelo trabalho, além dos benefícios da Previdência Social. Conforme o artigo 29, da Lei de Execução Penal, a remuneração não poderá ser inferior a 3/4 (três quartos) do salário mínimo. Esse valor deverá atender à indenização dos danos causados pelo crime, desde que determinados judicialmente e não reparados por outros meios, à assistência à família, a pequenas despesas pessoais, e ao ressarcimento ao estado das despesas realizadas com a manutenção do condenado, em proporção a ser fixada e sem prejuízo da destinação prevista nas letras anteriores.

Caso haja alguma parte restante, esta deverá constituir pecúlio, em conta poupança, que será entregue ao condenado quando posto em liberdade.

Assim, os presos deveriam ser remunerados de forme justa, mas essa matéria é objeto de práticas irregulares e atentatórias aos direitos do interno. Valores pagos pela

\footnotetext{
${ }^{221}$ CATÃO, Yolanda; SÜSSEKIND, Elisabeth. Os direitos do preso. In: FrAGOSO, Heleno Cláudio; CATÃO, Yolanda; SÜSSEKIND, Elisabeth. Direitos dos presos. Rio de Janeiro: Forense, 1980. p. 104-106.

${ }^{222}$ FRAGOSO, 1980-b, p. 31-33.

${ }^{223}$ BRASIL. MinisTÉRIO DA JUSTIÇA, 2011, p. 5-6, 10, 20.
} 
indústria, por exemplo, só excepcionalmente equivale ao salário mínimo ${ }^{224}$, sendo o preso visto como mão-de-obra barata e isenta de encargos sociais, desestimulando-o ${ }^{225}$.

Conforme disposição do artigo 32, da Lei de Execução Penal, na atribuição do trabalho ao preso, devem ser consideradas a habilitação, a condição pessoal e as necessidades futuras do preso, bem como as oportunidades oferecidas pelo mercado. Salvo nas regiões de turismo, deverá ser limitado, tanto quanto possível, o artesanato sem expressão econômica.

Apesar desta disposição, o trabalho do encarcerado não contribui para a formação profissional dele e não o prepara para o retorno à vida em liberdade, apenas evitando a ociosidade dentro dos presídios ${ }^{226}$.

Na Penitenciária de Franca, os presos trabalhavam na faxina, cozinha e manutenção das instalações do prédio; na Cadeia Pública Feminina de Franca, havia 30 vagas para trabalho na confecção de cigarros; e em Bauru, havia apenas algumas vagas de trabalho na faxina do prédio $^{227}$.

Percebe-se, portanto, que a administração dos presídios também usa os presos como mão-de-obra para a manutenção das instalações carcerárias, atribuindo tarefas aos presos que não trazem a eles qualificação profissional.

A distribuição de tarefas na prisão não guarda relação com a atividade econômica do trabalho livre. Ainda, as atividades fornecidas em oficinas são intrínsecas do cárcere,

\footnotetext{
${ }^{224}$ Apesar dessa garantia de remuneração mínima, na Penitenciária de Presidente Prudente I, no estado de São Paulo, havia vagas de trabalho numa oficina montada dentro do local por uma empresa que fabricava artigos de festa, onde os presos recebiam apenas $\mathrm{R} \$ 140$ ou $\mathrm{R} \$ 150$ pelo trabalho, valor aquém do mínimo previsto na Lei de Execução Penal (BRASIL. MinistÉRIO DA JUSTIÇA, 2011, p. 26). FRAGOSO lembra que a remuneração dos presos deve ser equitativa, conforme art. 76, das Regras Mínimas para o Tratamento dos Reclusos, e que, se o pagamento é ínfimo e não corresponde ao trabalho realizado, a atividade laborativa se torna castigo e se integra no sistema punitivo (FRAGOSO, 1980-b, p. 31-33).

${ }^{225}$ CATÃO; SÜSSEKIND, 1980, p. 104-108.

${ }^{226}$ OliveIRA, Gláucio Araújo de. Trabalho penitenciário à luz da lei de execução penal. In: MARCHI JR, Antônio de Padova; PINTo, Felipe Martins (Coord.); Fernandes, Agostinho; LACERdA, Bruno Amaro (Colab.). Execução penal: constatações, críticas, alternativas e utopias. Curitiba: Juruá, 2008. p. 282.

${ }^{227}$ BRASIL. MiNISTÉRIO DA JUSTIÇA, op. cit., p. 4-5 e 18.
} 
como, por exemplo, a costura de bolas esportivas, dispensando as empresas de modernizar seus equipamentos e de contratar mão-de-obra ao custo do mercado. Por ser as atividades fornecidas nos estabelecimentos prisionais "trabalho de preso", o recluso não encontra esses empregos que adquiriu experiência quando livre, pois são fornecidos apenas dentro do cárcere, como meio de redução de custos das empresas ${ }^{228}$.

Quando postos em liberdade, o preso encontra dificuldade em se integrar ao mercado de trabalho, pois, além do preconceito, têm baixa qualificação profissional e iníqua experiência, em razão dos serviços desqualificados realizados ${ }^{229}$.

A prisão deveria aproveitar a oportunidade e utilizar de maneira mais produtiva o período da pena e desenvolver as aptidões dos internos ${ }^{230}$.

Mesmo com os objetivos que o trabalho prisional almeja alcançar, tais como profissionalizar e dar trabalho ao preso, o trabalho na prisão, além de não levar em consideração as habilidades e trabalhos já realizados pelo preso, sua organização, como o processo de trabalho, jornada e remuneração, é diferente da que o preso encontrará quando posto em liberdade ${ }^{231}$.

Além das oficinas mal administradas e com falta de equipamentos e matériasprimas adequadas, denota-se a falta de interesse estatal em construir unidades prisionais voltadas para o exercício de atividades laborais ${ }^{232}$.

Por fim, o artigo 126, da Lei de Execução Penal, estabeleceu que o condenado que cumpre a pena em regime fechado ou semiaberto poderá remir, por trabalho ou por estudo, parte do tempo de execução da pena.

\footnotetext{
${ }^{228}$ BRANT, 1994, p. 123-127.

229 MADEIRA, Lígia Mori. A atuação da sociedade civil na ressocialização de egressos do sistema penitenciário: a FAESP como objeto de pesquisa. Revista Transdisciplinar de Ciências Penitenciárias, Pelotas, v. 2, n. 1, p. 108-111, jan./dez. 2003.

${ }^{230}$ Conforme artigo 71.5, das Regras Mínimas para o Tratamento dos Reclusos, "deve ser proporcionado treino profissional em profissões úteis aos reclusos que dele tirem proveito, e especialmente a jovens reclusos".

${ }^{231}$ MADEIRA, op. cit., p. 98-104.

${ }^{232}$ OliveIRA, 2008, p. 280-281.
} 
A contagem da remição é feita à razão de 1 (um) dia de pena a cada 12 (doze) horas de frequência escolar (atividade de ensino fundamental, médio, inclusive profissionalizante, ou superior, ou ainda de requalificação profissional), divididas, no mínimo, em 3 (três) dias; ou de 1 (um) dia de pena a cada 3 (três) dias de trabalho ${ }^{233}$.

Ainda, conforme os parágrafos deste artigo, para fins de cumulação dos casos de remição, as horas diárias de trabalho e de estudo devem ser definidas de forma a se compatibilizarem, e o preso impossibilitado, por acidente, de prosseguir no trabalho ou nos estudos continuará a beneficiar-se com a remição.

No caso de conclusão do ensino fundamental, médio ou superior durante o cumprimento da pena, desde que certificada pelo órgão competente do sistema de educação, o tempo a remir em função das horas de estudo será acrescido de 1/3 (um terço).

A remição do tempo de pena a ser cumprida também é aplicada ao condenado que cumpre pena em regime aberto ou semiaberto e o que usufrui liberdade condicional, pela frequência a curso de ensino regular ou de educação profissional.

Em caso de falta grave, o juiz poderá revogar até 1/3 (um terço) do tempo remido, recomeçando a contagem a partir da data da infração disciplinar, conforme estabelece o artigo 127, da Lei de Execução Penal.

Contudo, apagar o tempo já remido, em casos de falta grave, como previsto neste dispositivo acima, pode trazer indignação ao preso, desincentivando-o a continuar com as atividades laborativas, pois todo o esforço empenhado visando à remição foi transformado em nada ao revogar o tempo já remido ${ }^{234}$.

\footnotetext{
$\overline{233}$ Conforme o artigo 126, § 2 , da Lei de Execução Penal, as atividades de estudo poderão ser desenvolvidas de forma presencial ou por metodologia de ensino a distância. VALOIS lembra que o trabalho e a remissão são direitos do preso. Assim, apesar de este entendimento não estar consolidado nos tribunais, em caso de falta de vagas para os presos trabalharem, eles têm direito à remissão ficta; ou seja, podem remir o tempo de pena mesmo não trabalhando, pois a falta de vagas de deu em razão da inércia do Estado em disponibilizar os postos de trabalho (VALOIS, 2013, p. 137-138). Nesse mesmo sentido, SHECAIRA; CORRÊA JR., 2002, p. 337. ${ }^{234}$ SHECAIRA; CORRÊA JR., op. cit, p. 341-344.
} 


\subsubsection{Da disciplina}

Conforme o artigo 44, da Lei de Execução Penal, o preso deve colaborar com a ordem, na obediência às determinações das autoridades e seus agentes e no desempenho do trabalho. Estarão sujeitos a essa disciplina os condenados à pena privativa de liberdade ou restritiva de direitos e o preso provisório.

A disciplina tem por objetivo manter a segurança e a ordem internas, preocupação do sistema carcerário.

Conforme os artigos 27 e 28, das Regras Mínimas para o Tratamento dos Reclusos, a ordem e a disciplina devem ser mantidas com firmeza, mas sem impor restrições além das necessárias para a manutenção da segurança e da boa organização da vida comunitária.

No entanto, em alguns presídios, como os de segurança máxima do estado do Espírito Santos, constatou-se um regime de vigilância e locomoção dos presos extremamente duro e repressivo, que pode deixar sequelas psicológicas nos detentos ${ }^{235}$. No estado de São Paulo, também, encontra-se esse regime mais repressivo como, por exemplo, na Penitenciária de Avaré I, onde os presos têm um rigoroso monitoramento em sua locomoção e, em Presidente Bernardes, onde os presos são algemados durante os deslocamentos na unidade ${ }^{236}$.

O artigo 45, da Lei de Execução Penal, estabelece que não haverá falta nem sanção disciplinar sem expressa e anterior previsão legal ou regulamentar. Essas sanções, ainda, não poderão colocar em perigo a integridade física e moral do condenado, sendo vedado o emprego de cela escura e as sanções coletivas.

As faltas disciplinares são classificadas em leves, médias e graves, sendo que apenas as graves são especificadas na Lei de Execução Penal. Incube à legislação local especificar as faltas leves e médias, bem como as respectivas sanções.

\footnotetext{
$\overline{235}$ ORGANIZAÇÃO DAS NAÇÕES UNIDAS, 2012, p. 19.

${ }^{236}$ BRASIL. MINISTÉRIO DA JUSTIÇA, 2011, p. 21-22 e 27-28.
} 
$\mathrm{O}$ condenado à pena privativa de liberdade comete falta grave se: incitar ou participar de movimento para subverter a ordem ou a disciplina; fugir; possuir, indevidamente, instrumento capaz de ofender a integridade física de outrem; provocar acidente de trabalho; descumprir, no regime aberto, as condições impostas; desobedecer ao servidor ou desrespeitar a qualquer pessoa com quem deva relacionar-se; deixar de executar o trabalho, as tarefas e as ordens recebidas; e tiver em sua posse, utilizar ou fornecer aparelho telefônico, de rádio ou similar, que permita a comunicação com outros presos ou com o ambiente externo.

Já o condenado à pena restritiva de direitos comete falta grave se: descumprir, injustificadamente, a restrição imposta; retardar, injustificadamente, o cumprimento da obrigação imposta; desobedecer ao servidor ou desrespeitar a qualquer pessoa com quem deva relacionar-se; e deixar de executar o trabalho, as tarefas e as ordens recebidas.

As faltas discriminadas acima estão sujeitas às seguintes sanções, conforme dispõe o artigo 53, da Lei de Execução Penal: advertência verbal; repreensão; suspensão ou restrição de direitos; isolamento na própria cela, ou em local adequado, nos estabelecimentos que possuam alojamento coletivo, observado o disposto no artigo 88 desta Lei, que determina que a cela individual deve conter dormitório, aparelho sanitário e lavatório; e inclusão no regime disciplinar diferenciado.

Além de trazer as faltas e as sanções, a lei também deve prever as regras do processo disciplinar, de modo a assegurar a defesa do condenado, e um sistema de recursos. Ainda, de modo a coibir violência e arbítrio em relação à disciplina, os sistemas carcerários deveriam ser dotados de um sistema de reclamação para uso dos internos ${ }^{237}$.

\subsubsection{Regime disciplinar diferenciado}

A Lei Federal no 10.792/2003 alterou a Lei de Execução Penal e o Código de Processo Penal, estabelecendo uma nova modalidade de cumprimento de pena privativa de

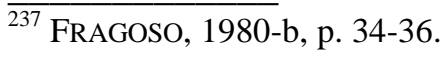


liberdade - o regime disciplinar diferenciado, que, dois anos antes da vigência desta lei, já era aplicado nos estados de São Paulo e do Rio de Janeiro.

Em maio de 2001, a Secretaria de Administração Penitenciária do estado de São Paulo, por meio da Resolução $\mathrm{n}^{\circ}$ 26, impôs aos líderes e integrantes de facções criminosas o regime disciplinar diferenciado, bem como aos presos cujo comportamento exigisse esse tratamento de contenção.

Essa resolução decorreu de uma megarrebelião, ocorrida no início de 2001, quando presos de 29 unidades prisionais se rebelaram como resposta às ações do governo que tentavam dissuadir o grupo criminoso Primeiro Comando da Capital - PCC, ao transferir seus líderes para locais distantes da capital do estado.

As manifestações foram causadas principalmente pela defesa da organização criminosa, pois apenas no dia seguinte ao início da megarrebelião foram apresentadas denúncias em relação às más condições das prisões, maus tratos, má qualidade da alimentação, falta de assistência médica e jurídica, arbitrariedades cometidas pelos agentes penitenciários $^{238}$.

Em julho de 2002, uma nova resolução da Secretaria de Administração Penitenciária, a Resolução $n^{\circ} 49$, restringiu a visita de advogados a esses presos que estavam isolados ${ }^{239}$.

Da mesma forma, no estado do Rio de Janeiro, houve uma rebelião na penitenciária de Bangu I, em dezembro de 2002, liderada por um membro de uma facção criminosa, onde houve o confronto de dois grupos criminosos. Após esse episódio, foi criado o regime disciplinar especial de segurança, sendo justificada sua criação como instrumento

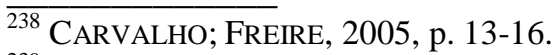

239 Essas resoluções poderiam ser consideradas ilegais, pois, como se depreende do artigo 49, da Lei de Execução Penal, a competência para legislar sobre faltas graves é federal. Mas, mesmo assim, tal medida alcançou âmbito nacional como alternativa de sanção disciplinar ao preso que vier a cometer falta grave (Zurlo, Roberta; SILVA, Marcelo Motta Coelho. A mudança do conceito de disciplina na execução penal: a institucionalização do RDD (Regime Disciplinar Diferenciado). Revista Transdisciplinar de Ciências Penitenciárias, Pelotas, v. 4, n. 1, p. 29-33, jan./dez. 2005).
} 
disciplinar para proporcionar condições para a harmônica integração social dos demais condenados, afastando os líderes opressores dos detentos subjugados, usados como massa de manobra daqueles. Seriam construídos presídios especiais para abrigar os criminosos cuja presença entre os demais presos colocava em risco a ordem e a disciplina internas, além da integridade física dos outros detentos ${ }^{240}$.

Assim, após o uso desse instrumento de isolamento pelos estados de São Paulo e Rio de Janeiro, esta medida foi nacionalizada pela Lei Federal n ${ }^{\circ} 10.792 / 2003$, que, além do objetivo de recrudescer a disciplina interna dos estabelecimentos penitenciários, quis retomar o controle do Poder Público sobre os estabelecimentos penais, em razão da nova realidade carcerária brasileira que se apresentava naquele momento ${ }^{241}$.

Desta forma, após os episódios citados acima, a Lei Federal no 10.792/2003 nacionalizou o regime disciplinar diferenciado. Essa nova modalidade, prevista no artigo 52, da Lei de Execução Penal, modificou a estrutura das faltas disciplinares, ao incluir o regime disciplinar diferenciado como sanção, prevendo que os presos que praticarem falta grave constituída na prática de fato previsto como crime doloso e que ocasione subversão da ordem ou da disciplina internas poderão ser recolhidos em cela individual, por até 360 dias, sem prejuízo de repetição da sanção por nova falta grave da mesma espécie, até o limite de um sexto da pena aplicada, tendo apenas 2 (duas) horas de banho de sol diário e 2 (duas) visitas semanais com duração de 2 (duas) horas, sem contar as crianças. Caracterizase, desta forma, esta sanção, pelo maior isolamento do preso e pela maior restrição de contato com o mundo externo.

Também podem ser submetidos a esta sanção, conforme os parágrafos do artigo 52, da Lei de Execução Penal, os presos provisórios ou condenados, que apresentem alto risco para a ordem e a segurança do estabelecimento penal ou da sociedade, ou sob os quais recaiam fundadas suspeitas de envolvimento ou participação, a qualquer título, em organizações criminosas, quadrilha ou bando.

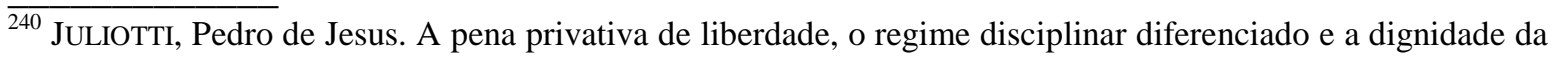
pessoa humana. Justitia, São Paulo, v. 65, n. 198, p. 28-29, jan./jun. 2008.

${ }^{241}$ ZURLO; SILVA, 2005, p. 28-29.
} 
Nota-se que o regime disciplinar diferenciado pode se caracterizar como uma modalidade de sanção de longa duração ao submeter um preso provisório a tal regime nas condições impostas pela lei, pois não é possível calcular o limite máximo de um sexto da pena uma vez que o preso sequer foi ainda condenado ${ }^{242}$.

A adoção dessa medida demonstra a cultura de emergência e simbólica fundada na flexibilização de princípio penais, no aumento da violência nos presídios, no auxílio da mídia para propagar medos e fazer vinculação da impunidade ao "excesso" de direitos e garantias dos presos provisórios e condenados ${ }^{243}$. A adoção desse Direito Penal preventivo, de risco, menos compatível e harmônico com os marcos constitucionais, leva a uma relativização dos princípios político-criminais de garantia ${ }^{244}$.

Essa alteração legislativa foi idealizada pretendendo combater o aumento da violência, o crime organizado e o sentimento de insegurança na sociedade ${ }^{245}$. Ocorre que, ao fim, acabou rotulando determinados presos como ameaça à segurança e estabeleceu um regime de cumprimento de pena mais severo do que o regime fechado.

A aplicação do regime disciplinar diferenciado tem ênfase na inabilitação e na exclusão, sendo caracterizado pela tentativa de proteção ao público, neutralizando e incapacitando aqueles que se encontram cumprindo esta medida, pois o preso fica isolado 22 horas por dia, tendo apenas 2 horas de banho de sol diários. Esse isolamento por longo período rompe com a lógica do sistema progressivo de penas e viola os direitos e garantias individuais, sendo aplicado aos presos com alta periculosidade, ainda que não tenham praticado falta grave, de modo a responder aos desejos imanentes de segurança ${ }^{246}$.

\footnotetext{
${ }^{242}$ MourA, Maria Thereza Rocha de Assis. Notas sobre a inconstitucionalidade da lei n. 10.792/2003, que criou o regime disciplinar diferenciado na execução penal. Revista do Advogado, São Paulo, v. 24, n. 78, p. 64, set. 2004.

${ }^{243}$ CARVAlHO; FReire, 2005, p. 17-19.

244 AbEl Souto, Miguel. Teorías de la pena y límites al ius puniendi desde el Estado democrático. Madrid: Dilex, 2006. p. 55-58.

${ }^{245}$ Na Penitenciária de Presidente Bernardes, do estado de São Paulo, local destinado a presos submetidos ao regime disciplinar diferenciado, quando houve a inspeção do CNPCP, não havia, lá, líderes de organização ou facções criminosas, contrariando a pretensão da adoção de tal sanção. A maioria dos presos estava lá em decorrência de agressão a funcionários da administração penitenciária (BRASIL. MINISTÉRIO DA JUSTIÇA, 2011, p. 28).

${ }^{246}$ CARVAlHO; FreIRE, op. cit., p. 7-10.
} 
Como visto, é possível incluir, no regime disciplinar diferenciado, presos em razão de sua conduta pessoal, bastando apresentar alto risco para a ordem e a segurança do estabelecimento penal ou da sociedade, ou ainda que recaiam sobre eles fundadas suspeitas de envolvimento em organizações criminosas, quadrilha ou bando. Percebe-se, também, a adoção pela Lei de Execução Penal do conceito de periculosidade, que utiliza o isolamento proporcionado pelo regime disciplinar diferenciado como meio de inocuização dos presos que podem ser assim adjetivados ${ }^{247}$.

A taxatividade da lei também restou prejudica com a inclusão do regime disciplinar diferenciado na Lei de Execução Penal. Os parágrafos do artigo 52 apresentam termos que possibilitam uma interpretação extensiva, tais como "alto risco" e "fundadas suspeitas", resultando numa insegurança para o preso ante o Estado, e deixando-os vulneráveis a interpretações subjetivas dos preceitos ${ }^{248}$.

O rol de faltas graves trazido na Lei de Execução Penal, no artigo 50, em especial os incisos I e VI, também apresenta termos vagos e genéricos, sem precisão semântica, o que pode levar ao arbítrio dos funcionários que atuam junto aos presos, que podem utilizar dessa imprecisão para caracterizar como faltas graves condutas sem relevância dos presos.

Esse rol deveria atender estritamente ao princípio da legalidade, descrevendo adequadamente as condutas que se constituem faltas graves, para impedir arbitrariedades na execução penal ${ }^{249}$.

A regulamentação do regime disciplinar diferenciado também compromete a jurisdicionalização da execução penal, pois, conforme o artigo 60, da Lei de Execução Penal, é possível à autoridade administrativa a decretação do isolamento preventivo do faltoso pelo prazo de 10 dias, sem um anterior processo disciplinar homologado pelo juiz da execução, ou, no caso de motim, terá 24 horas para comunicar o juiz competente após a

\footnotetext{
$\overline{247}$ NAHUM, Marco Antonio Rodrigues. O retorno dos conceitos de periculosidade, e de inocuização, como defesa da sociedade globalizada. Boletim IBCCRIM, São Paulo, v. 13, n. 161, p.14-15, abr. 2006.

${ }^{248}$ FERREIRA; CUTIÑO RAYA, 2004, p. 263-268.

${ }^{249}$ MOURA, 2004, p. 64.
} 
transferência. Desta forma, restringe-se um direito do preso sem anterior decisão judicial fundamentada.

É necessário efetivar um modelo acusatório na execução penal, sob pena de se adotar um direito penal do autor, incompatível com a Constituição Federal de $1988^{250}$.

O isolamento em cela por 22 horas diárias e a restrição de contato com o mundo exterior fere, ainda, a individualização da pena, pois desconsidera a justa medida entre a pena e o crime, calculada pelo juiz da instrução, e torna letra morta o programa individualizador da pena elaborado para o preso $^{251}$.

Elimina-se, ademais, com o regime disciplinar diferenciado, qualquer objetivo ressocializador da pena, objetivo este previsto no artigo $1^{\circ}$, da Lei de Execução Penal, da mesma forma que tentou fazer a Lei Federal $n^{\circ}$ 8.072/1990 (Lei de Crimes Hediondos) ao estabelecer um modelo de cumprimento de pena integralmente em regime fechado.

Essa inovação legislativa abdicou do fim ressocializador da pena, adotando um direito penal do inimigo, fundado numa política criminal autoritária que não se ajusta com os regimes democráticos ${ }^{252}$. Essa nova modalidade de cumprimento de pena não permite uma reintegração social gradual do apenado, pois o isola e restringe seu contato com o mundo externo, criando um regime fechado mais severo, regido por disposições de cunho inabilitador ${ }^{253}$.

Por fim, o regime disciplinar diferenciado é uma "sobrepena" cruel e degradante, que fere a dignidade do condenado, destruindo emocional, física e psicologicamente a pessoa a ele submetida, e impondo-lhe castigo físico e moral, como, por exemplo, mantendo-o isolado por 22 horas diárias ${ }^{254}$, violando, desta forma, a proibição

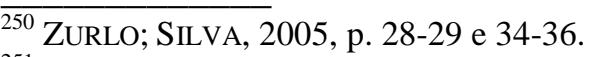

${ }^{251}$ MOURA, 2004, p. 64.

${ }^{252}$ FERREIRA; CUTIÑO RAYA, 2004, p. 257-259.

${ }^{253}$ CARVALHO; FREIRE, 2005, p. 24-26.

${ }^{254}$ Moura, op. cit, p. 64. Nesse mesmo sentido, CARVAlHo; Freire, op. cit, p. 23-24. Acrescentam FranCO, LIRA e FELIX que, além de ser uma pena cruel e desumana, é inconstitucional e inadmissível num Estado
} 
constitucional de adoção dessas penas e o respeito à integridade física e moral dos $\operatorname{presos}^{255}$. O sofrimento trazido por este regime é superior àquele necessário para a aplicação da pena privativa de liberdade, cuja finalidade é também a reinserção social do condenado, agravando as condições de vida dentro do cárcere e a dessocialização do preso $^{256}$.

Assim, além de focar-se na segregação de presidiários, a aplicação deste isolamento ofende os direito e garantias constitucionais assegurados aos acusados e condenados. A sanção, além de ser desproporcional, afeta direitos não restringidos na sentença condenatória.

É, portanto, o regime disciplinar diferenciado, antagônico à dignidade humana e ao princípio da humanidade ${ }^{257}$.

\subsection{Da função ressocializadora da pena privativa de liberdade}

As penas no Brasil têm suas finalidades definidas no artigo 59, do Código Penal, que dispõe que a reprovação e prevenção de crimes devem ser os objetivos da aplicação da lei penal. $\mathrm{O}$ artigo $1^{\circ}$, da Lei de Execução Penal, complementa tal dispositivo, estabelecendo que, além de efetivar as disposições contidas na sentença criminal, a execução penal tem por objetivo proporcionar a harmônica integração social do condenado.

Democrático de Direito, mesmo em nome da segurança coletiva, diante do crime organizado (FRANCO; LIRA; FELIX, 2011, p. 81-83).

${ }^{255}$ O regime disciplinar diferenciado vai de encontro, também, ao artigo 31, das Regras Mínimas de Tratamento dos Reclusos, que dispõe que "as penas corporais, a colocação em "segredo escuro" bem como todas as punições cruéis, desumanas ou degradantes devem ser completamente proibidas como sanções disciplinares".

${ }^{256}$ FERREIRA; CUTIÑO RAYA, 2004, p. 271-279.

257 CARVAlHO; Freire, 2005, p. 23-24; FrAnCO; LiRA; FeliX, op. cit., p. 81-83. Em sentido contrário, MIRABETE e FABBRINI, e JULLIOTI, que acreditam que esta medida atende ao princípio da proporcionalidade, pois há equivalência entre a gravidade da falta e a severidade da sanção imposta (JULIOTTI, 2008, p. 30-32 e Mirabete, Júlio Fabbrini; FABBrini, Renato N. Execução Penal. 12a ed. São Paulo: Atlas, 2014. p. 150). 
Esses dispositivos estão em consonância com o artigo $6^{\circ}$, da Convenção Americana de Direitos Humanos, que disciplina que as penas privativas de liberdade devem ter por finalidade essencial a reforma e a readaptação social dos condenados.

Como já visto, tendo em vista o princípio da humanidade, essa finalidade da pena privativa de liberdade não pode importar em atuação sobre a conformação moral do condenado ou representar uma intervenção coativa sobre sua personalidade ou uma manipulação forçada de seus valores. Deve ser uma amostra das alternativas e escolhas que há fora da prisão, para que, quando livre, o criminoso opte por respeitar determinadas regras essenciais à convivência social. A realização de qualquer tratamento deve ser precedida de livre e espontâneo consentimento do preso ${ }^{258}$.

Assim, por respeito à dignidade da pessoa, não é possível sujeitar alguém a uma intervenção imoderada em sua personalidade, de modo a tratá-lo como mero objeto do exercício do poder estatal. Quando preso, os direitos fundamentais da pessoa não são suspensos, sendo apenas sujeitos às limitações que a natureza da pena justifique ${ }^{259}$.

Por isto, deixa-se, então, de falar em ressocialização do condenado para referir-se à reintegração social deste ${ }^{260}$.

Para reintegrar o indivíduo à sociedade, é necessário resolver o conflito causado pelo crime, que o cumprimento da pena imposta não resolve, pois são subjacentes à infração criminal. Para isto, é necessário envolver todas as partes, tanto os infratores, quando a sociedade e as vítimas, trabalhando as relações dessas partes envolvidas, pois a

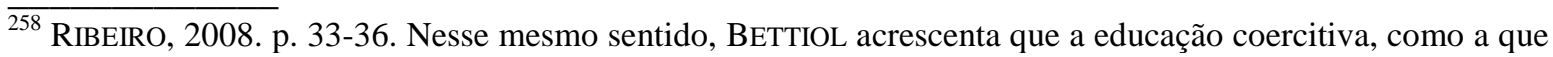
ocorre no cárcere, acarreta um dano profundo à liberdade de orientação e consciência do detido (BETTIOL, Giuseppe. O mito da reeducação. Revista Brasileira de Criminologia e Direito Penal, Rio de Janeiro, v. 2, n. 6, p. 11, jul./set. 1964).

${ }^{259}$ FigueIREDO, Frederico Antunes de Oliveira. Da participação da comunidade na execução das penas privativas de liberdades. Revista do Conselho Nacional de Política Criminal e Penitenciária, Brasília, n. 16, p. 63-66, jan./jul. 2003.

${ }^{260}$ Para BARATTA, não é possível falar em ressocialização, pois o cárcere, como instituição total, não permite tal fenômeno. Deve-se falar, portanto, em reintegração do indivíduo à sociedade onde ele praticou o delito que o levou ao cumprimento da pena privativa de liberdade (BARATTA, Alessandro. Criminología y sistema penal: compilación in memorian. Montevidéu: Editoriao B de F, 2004. p. 20). Já para VALOIS, ressocialização e legalidade não se coadunam, pois o conteúdo de ressocialização é ambíguo, podendo prejudicar o preso. Para ele, o termo "ressocialização" deveria ser trocado por "respeito à dignidade humana" (VALOIS, 2013, p. 223-228).
} 
adequação das respostas aos conflitos posteriores vai depender de como foram solucionados os anteriores ${ }^{261}$.

O foco do tratamento carcerário deve deixar de ser somente o indivíduo e se deslocar para o complexo de relações entre o apenado e a sociedade e todo o seu histórico familiar, de segregação e exclusão. O tratamento deve operar sobre a vulnerabilidade, a personalidade deteriorada, e não sobre a conduta desviada ${ }^{262}$. Por isso a utilização do termo “reintegração social”, aproximando o cárcere da sociedade ${ }^{263}$.

A relação do indivíduo com a sociedade deve ser trabalhada, pois, muitas vezes, ele apresenta uma inabilidade na solução dos conflitos oriundos do convívio com a sociedade, que provem de toda uma história de marginalização escolar e social, da qual o indivíduo foi vítima, sofrendo um processo de deterioração e se tornando mais frágil perante o sistema penal e punitivo que, consequentemente, o criminalizou pelas normas seletivas do mesmo $^{264}$.

Ademais, realizando o encontro entre a vítima e o agressor, é possibilitado à vítima a superação do trauma e a compreensão do agressor, e, ao agressor, é possível a conscientização sobre as consequências do crime ${ }^{265}$.

Contudo, apesar dos ideais que se queira atingir quanto à reintegração social do condenado, não é possível deixar de lado determinados problemas como o abismo entre a legislação e a realidade brasileira e as condições inerentes ao cárcere, que dificultam esse processo.

O cenário carcerário no Brasil é de decadência e abandono. A precariedade física, aliada a todos os problemas relatados, como falta de assistência aos presos, manutenção de

\footnotetext{
${ }^{261}$ SÁ, Alvino Augusto de. Concepção de crime como expressão de uma história de conflitos: implicações na reintegração social dos condenados à pena privativa de liberdade. Revista da ESMESC: Escola Superior da Magistratura do Estado de Santa Catarina, Florianópolis, v. 7, n. 11, p. 169 e 177-178, 2001.

${ }^{262}$ Necessário ressaltar que nem todas as formas de criminalidade se encaixam nesse modelo, a exemplo dos crimes contra o sistema financeiro e crimes ambientais.

${ }^{263}$ SÁ, op. cit., p. 173-177.

${ }^{264}$ Ibid., p. 170-173.

${ }^{265}$ Ibid., p. 173-177.
} 
apenados em cadeias públicas, prática de tortura e violência pelos funcionários que deveriam zelar pela integridade física e psicológica dos presos, a insuficiência de estabelecimentos para o cumprimento de pena privativa de liberdade nos regimes aberto e semiaberto, choca-se com qualquer proposta de reintegração social.

A prisão apresenta um custo alto de manutenção e não consegue reprimir a criminalidade, apresentando altos índices de reincidência e funcionando como uma especialização para o crime. Hoje, o cárcere atua como um fator criminógeno, desajustando o indivíduo da convivência social e tornando-o mais propenso à violência ${ }^{266}$.

O sistema prisional, da forma que atualmente se encontra, é realimentador; ou seja, quando mais grave a pena, e, consequentemente, quanto mais tempo o indivíduo permanece na prisão, maior a chance de reincidência ${ }^{267}$.

Quando o indivíduo é posto em liberdade, ele ainda encontra todos os problemas que o levaram a delinquir, pois se vê a diminuição do Estado quanto a políticas sociais, que seriam voltadas a diminuir a exclusão e a desigualdade social ${ }^{268}$.

Não se pode deixar de ressaltar que a pena não é substitutiva das deficiências do Estado Social e que favorece a criação de uma sociedade excludente e opressora ${ }^{269}$.

Para se reintegrar nas articulações sociais, o tratamento dado ao preso deve eliminar as causas de incompatibilidade entre o indivíduo e o grupo o qual irá conviver e gradativamente prepará-lo para a vida coletiva e às suas exigências ${ }^{270}$.

\footnotetext{
${ }^{266}$ RIBEIRO, 2008, p. 33-36.

${ }^{267}$ FRAGOSO, 1980-a, p. 6-7.

${ }^{268}$ MADEIRA, 2003, p. 98-104.

269 SALVADOR NeTTO, Alamiro Velludo. Finalidades da pena: conceito material de delito e sistema penal integral. São Paulo: Quartier Latin, 2009. p. 316. Para FRAGOSO, a prisão é um privilégio dos pobres e desfavorecidos, pois a criminalidade do colarinho branco, por exemplo, é imune ao sistema (FRAGOSO, op. cit., p. 8-9). Nesse mesmo sentido, IGNACIO BAÑOS, Javier. El fundamento de la pena: máximo problema penal. Buenos Aires: Ediar, 2011. p. 200. Questões sociais são respondidas, pelo governo neoliberal, com a atuação do Estado policial, punitivo e encarceratório. Desta forma, priorizam-se os investimentos em segurança e encarceramento, em detrimento dos investimentos sociais (TORRES, Andrea Almeida. Críticas ao tratamento penitenciário e a falácia da ressocialização. Revista de Estudos Criminais, Porto Alegre, v. 7, n. 26, p. 114-118, jul./set. 2007).
} 
A pena privativa de liberdade expande uma subcultura criminal, com o surgimento de relações de poder hierarquizadas ${ }^{271}$, tanto entre os presos e funcionários, quanto entre os próprios reclusos. Na relação entre os funcionários e os presos, estes são vistos como não merecedores de confiança, e, com a rejeição social, os presos passam a se sentir inferiores, levando a percepção de si mesmo como desviantes, e passam a viver conforme esta imagem, marginalmente ${ }^{272}$. Há, dentro do cárcere, uma cultura arraigada em que os funcionários, conhecidos como "cadeeiros", se consideram como detentores de um saber exclusivo de como lidar com os presos. Estes têm como prioridade a segurança do estabelecimento; por isso, quanto mais fechado o cárcere, melhor, mesmo em relação à participação da sociedade na execução da pena ${ }^{273}$.

Entre os reclusos são formados subgrupos, de onde se sobressai uma liderança informal, que se organizam em função de um subsistema social que repudia o modo de vida, o poder e os valores da sociedade. Ainda, esses grupos têm a capacidade de intimidar, submeter e dominar outros presos e resolver os conflitos e disputas com que se deparam através da força ${ }^{274}$.

Há, nas prisões, ainda, o autogoverno por líderes do crime organizado, que comandam o narcotráfico intra e extramuros ${ }^{275}$. Os presos acabam se dividindo entre as facções existentes, criando laços que irão prevalecer mesmo quando este for posto em liberdade, facilitando, muitas vezes, o caminho para a reincidência.

Da mesma forma que com os funcionários, cria-se um sistema social peculiar, que funciona com base em regras e valores próprios, ao qual o interno se adapta, formando um código de conduta, que visa a lealdade entre os reclusos, de modo a se contrapor aos

\footnotetext{
${ }^{270}$ BETTIOL, 1964, p. 9.

${ }^{271}$ MADEIRA, 2003, p. 98-104.

${ }^{272}$ RIBEIRO, 2008, p. 36-40.

${ }^{273}$ SÁ, Alvino Augusto de. A "ressocialização" de presos e a terceirização de presídios: impressões colhidas por um psicólogo em visita a dois presídios terceirizados. Revista da Fundação Escola Superior do Ministério Público do Distrito Federal e Territórios, Brasília, v. 11, n. 21, p. 21-22, jan./jun. 2003.

${ }^{274}$ RIBEIRO, op. cit., p. 52.

275 LEAL, César Barros. O sistema penitenciário: da desesperança ao otimismo responsável. Revista do Conselho Nacional de Política Criminal e Penitenciária, Brasília, n. 16, p. 29-33, jan./jul. 2003.
} 
funcionários penitenciários. Esses conjuntos de normas e valores coexistem com as regras oficiais da instituição ${ }^{276}$.

Necessário citar, ainda, a existência de uma relação corrupta entre os funcionários e os presos, que existe sob o conhecimento da administração carcerária, que propicia, por exemplo, segurança, entrada e manutenção de objetos proibidos. Esta relação encoraja os presos a continuarem enganando e burlando regras, além de afrontar os objetivos de reintegração social da pena, pois o interno não aprende a se submeter à autoridade regularmente constituída ${ }^{277}$.

Observa-se, também, uma incompatibilidade entre as metas formais de punição, prevenção e regeneração e as metas informais de segurança e disciplina. São princípios contraditórios a ressocialização e a segurança e disciplina internas do estabelecimento prisional. Para alcançar um resultado positivo da pena, o risco da segurança da execução deveria ser aceito como inevitável; contudo, a sociedade privilegia a segurança e a disciplina em detrimento da reinserção social ${ }^{278}$.

A justificativa de ressocialização converteu-se em ideia de segurança, segregação e neutralização; o delinquente passa a ser um objeto perigoso e o sistema penitenciário passa a ser melhor prendendo mais pessoas por mais tempo ${ }^{279}$.

A manutenção do indivíduo por longo tempo no estabelecimento penal causa, ainda, os efeitos da prisionização, e, enquanto a finalidade da pena exige maior autonomia do condenado, a prisão leva à regressão, fazendo com que a pessoa perca as condições de vida de um adulto ${ }^{280}$. O indivíduo, na prisão, sofre os efeitos da dessocialização e, quando retorna ao convívio social, volta com um estigma social irreversível ${ }^{281}$.

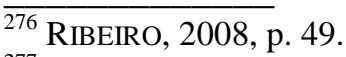

277 Ibid., p. 60.

${ }^{278}$ FIGUEIREDO, 2003, p. 58-61. Nesse mesmo sentido, TORRES, 2007, p. 112-114.

${ }^{279}$ SALVADOR NETTO, 2009, p. 314.

${ }^{280}$ FIGUEIREDO, op. cit., p. 58-61.

${ }^{281}$ TORRES, op. cit., p.118-123.
} 
Ademais, é tornar o objetivo da pena inalcançável tentar educar para a liberdade, privando de liberdade ${ }^{282}$. O cárcere não reproduz uma sociedade normal, a que lá existe é totalmente distinta daquela onde se pretende reintegrar o sujeito ${ }^{283}$.

Há, como já citado, problemas com o trabalho atribuído ao preso dentro do estabelecimento prisional, que pouco vai ser aproveitado quando este se encontrar em liberdade, não contribuindo para sua reintegração social.

Portanto, as condições inerentes ao cárcere e aquelas que existem em decorrência da realidade penitenciária brasileira não convergem para a reintegração social do condenado.

Desta forma, conclui-se que o sistema será eficiente se evitar colocar dentro da prisão as pessoas condenadas por crimes poucos graves; e, nos casos de crimes graves, evitar o encarceramento demasiadamente $\operatorname{longo}^{284}$, pois maiores serão as dificuldades de atingir a finalidade de reintegração social do condenado.

As penas principais deveriam ser ampliadas para abranger as sanções não privativas de liberdade, para que seja possível manter o condenado na comunidade, realizando suas atividades laborativas normais. Essa solução ainda representa um custo muito menor do que a aplicação da pena privativa de liberdade.

A prisão deveria ser apenas para aqueles condenados por crimes de grande danosidade social e multireincidentes ${ }^{285}$, que não podem, ainda, voltar ao convívio social.

A pena privativa de liberdade e o Direito Penal são necessários para garantir uma convivência social suportável, mas seu caráter imprescindível não implica que a prisão deve persistir da maneira como está hoje ${ }^{286}$. Para que a pena possa alcançar a finalidade de

\footnotetext{
$\overline{282}$ LEAL, 2003, p. 29-33.

283 BRANT, 1994, p. 107-111.

${ }^{284}$ FRAGOSO, 1980-a, p. 6-7.

${ }^{285}$ Ibid., p. 13-14.

${ }^{286}$ ABEL SOUTO, 2006, p. 55-58.
} 
reintegração social dos condenados, é necessário que, além do tratamento e atenção prioritários da execução penal e do respeito aos direitos do preso, seja a execução alicerçada na progressividade, que haja o número suficiente de estabelecimentos penais para a população carcerária no país, o aumento da aplicação de penas alternativas, o envolvimentos de grupos da sociedade no processo de reinserção social do condenado, e o controle e fiscalização da execução das penas pela magistratura, Ministério Público e Defensoria Pública ${ }^{287}$. 


\section{CAPÍTULO 3. DAS MEDIDAS DE SEGURANÇA}

\subsection{A medida de segurança no ordenamento jurídico brasileiro}

O Código Penal não permite a imposição de uma pena criminal aos inimputáveis que cometem fato típico e ilícito. Essas pessoas, se praticarem um fato descrito como crime, serão submetidas a uma medida de segurança, que é uma reação penal ${ }^{288}$, destinada à prevenção da criminalidade, com fins curativos e assistenciais ${ }^{289}$.

Essa medida constitui-se uma privação de bens jurídicos imposta jurisdicionalmente pelo Estado, e incide, principalmente, sobre a liberdade do indivíduo ${ }^{290}$.

O Código Penal adota o sistema vicariante de sanções penais, em que não é permitida a imposição cumulativa de pena e medida de segurança para a mesma pessoa pela prática do mesmo fato. Antes, o sistema duplo binário permitia a imposição de uma medida de segurança ao imputável, sucessivamente ao cumprimento da pena, caso fosse

\footnotetext{
${ }^{288}$ Há divergência doutrinária em relação à natureza da medida de segurança. É possível encontrar autores que afirmam que é uma providência administrativa, não aflitiva, sendo uma possibilidade de tratamento (entre eles, Costa JR., Paulo José da. Presunção normativa de perigosidade e jurisdicionalização da medida de segurança. Revista Brasileira de Criminologia e Direito Penal, Rio de Janeiro, v. 1, n. 1, p.137-138, abr./jun. 1963; ZAFFARONI; PIERANGeli, 2009, p. 731; BetTiOl, Giuseppe. Direito penal. v. 3. São Paulo: Revista dos Tribunais, 1976. p. 246) e aqueles que a consideram como uma reação penal, com caráter aflitivo em sua execução (entre eles, CARVALHO, Salo de. Penas e medidas de segurança no Direito Penal Brasileiro. $1^{a}$ ed., $2^{\mathrm{a}}$ tir. São Paulo: Saraiva, 2013. p. 508-510; DotTI, René Ariel. Penas e medidas de segurança no anteprojeto de código penal. Revista de Direito Penal, Rio de Janeiro, n. 32, p. 55-57, jul./dez. 1981; SÁ, Alvino Augusto de; Alves, Jamil Chaim; ZiMmARo, Rafael Barone. Medidas de segurança: necessárias reflexões pós-advento da Lei de Reforma Psiquiátrica (Lei 10.216/2001). Boletim IBCCRIM, São Paulo, v. 21, n. 249, p. 11-12, ago. 2013; QUEIROZ, Paulo de Souza. Direito penal: parte geral. 6. ed. Rio de Janeiro: Lumen Juris, 2010. p. 437).

${ }^{289}$ DOTTI, René Ariel. Visão geral da medida de segurança. In: SHECAIRA, Sérgio Salomão (Org.). Estudos criminais em homenagem a Evandro Lins e Silva: criminalista do século. São Paulo: Método, 2001. p. 310.

${ }^{290}$ PANCHERI, Ivanira. Medidas de segurança. Revista Brasileira de Ciências Criminais, São Paulo, v. 5, n. 20, p.106-107, out./dez. 1997.
} 
reconhecida sua periculosidade ${ }^{291}$. Desta forma, ou aplica-se a pena criminal ou a medida de segurança.

Aos inimputáveis é aplicada a medida de segurança, pois são destituídos de culpabilidade $^{292}$. Assim, se não há imputabilidade, não há culpabilidade, motivo pelo qual não a conduta praticada não pode ser adjetivada de crime, e, inexistindo crimes, não é possível aplicar uma pena criminal ${ }^{293}$.

A imposição desta medida tem como pressupostos a realização, pelo agente inimputável, de um injusto penal e a periculosidade deste ${ }^{294}$.

Necessário, então, que o inimputável tenha cometido um crime, depois de analisadas as causas excludentes da tipicidade, ilicitude, culpabilidade e punibilidade, inclusive prescrição ${ }^{295}$.

A periculosidade criminal é o comportamento de uma pessoa que tem grande probabilidade de causar um dano contra um bem tutelado. Ou seja, é a probabilidade de

\footnotetext{
${ }^{291}$ CARVAlHO, S., 2013, p. 504. Na redação original do Código Penal de 1940, adotava-se o sistema duplo binário, em que, após o cumprimento da pena privativa de liberdade, se ainda persistisse a periculosidade do agente, aplicava-se a medida de segurança por tempo indeterminado. Apesar de não ser o entendimento do autor, GRACIA MARTÍN assevera que o sistema duplo binário, com fim de inocuização, é uma medida que pode ir contra a dignidade humana e configurar-se um tratamento cruel e desumano, pois a finalidade de inocuização reduz o delinquente a um objetivo e seus direitos fundamentais, como a liberdade, são atingidos. Adotar uma medida de segurança após o cumprimento da pena não é uma medida estritamente necessária, e o Estado poderia recorrer a outros meios menos gravosos, como o controle do egresso, vigilância, regras de conduta (GRACIA MARTín, Luis. Sobre la legitimidad de medidas de seguridad contra delincuentes imputables peligrosos en el estado de derecho. In: GARCIA VALDÉs, Carlos et al (Coord.). Estudios penales en homenaje a Enrique Gimbernat I. Madrid: Edisofer, 2008. p. 989-990, 998-1000).

${ }^{292}$ Culpabilidade é a reprovabilidade da conduta ilícita de quem tem capacidade genérica de entender e querer, e que podia, nas circunstâncias em que o fato ocorreu, conhecer a ilicitude, sendo-lhe exigível, portanto, comportamento que se ajusta ao direito. Já a imputabilidade é a capacidade de culpa, pressuposto, e não elemento, da culpabilidade, representada pelo entendimento da antijuridicidade de seu comportamento e capacidade de autogoverno, que tem o maior de 18 anos (FraGOSO, Heleno Cláudio. Lições de direito penal: parte geral. 16. ed. Rio de Janeiro: Forense, 2004. p. 240-242).

${ }^{293}$ CARVALHO, S., op. cit, p. 500.

${ }^{294}$ DOTTI, 2001, p. 311-312.

295 QueIROZ, Paulo de Souza. Penas e medidas de segurança se distinguem realmente?. Boletim IBCCRIM, São Paulo, v. 12, n. 147, p. 15-16, fev. 2005.
} 
delinquir ${ }^{296}$. É o estado, mais ou menos duradouro, de antissociabilidade, que tem por base a conduta antissocial e a anomalia psíquica do agente ${ }^{297}$.

O legislador presumiu a periculosidade do inimputável, no artigo 26, caput, do Código Penal, tendo como base critérios biológicos e psicológicos ${ }^{298}$. Ao lado da periculosidade presumida, encontra-se, também, no Código Penal, a periculosidade real, no artigo 26, parágrafo único, atribuída ao semi-imputável, após verificação e investigação pelo juiz se é o caso de aplicação de pena ou de medida de segurança, sendo que esta é aplicada se houver necessidade de especial tratamento curativo ${ }^{299}$.

Assim, o inimputável tem sua periculosidade presumida pela lei, enquanto que o semi-imputável só será perigoso se houver determinação judicial nesse sentido.

Verificados, portanto, o fato típico e ilícito e a periculosidade, ao inimputável é dado um tratamento distinto daqueles que praticam uma ação típica, ilícita e culpável, pois, ao final da instrução processual, o magistrado absolve o agente, mas aplica-lhe uma medida de segurança ${ }^{300}$. Como não é possível aplicar uma pena adequada ao grau de reprovação do ato praticado, tendo em vista que o inimputável não tem condições cognitivas para direcionar sua vontade, substitui-se a finalidade retributiva da pena pela medida de segurança, que tem uma orientação de terapêutica ${ }^{301}$.

Para executar a medida de segurança, é necessário o trânsito em julgado da decisão que a impuser, conforme o artigo 172, da Lei de Execução Penal, não sendo mais possível

\footnotetext{
${ }^{296}$ DotTI, 2001, p. 310. A periculosidade pré-delitual, aquela em que se mede a probabilidade da pessoa ser autora de delitos no futuro não pode, no nosso ordenamento penal, ser utilizada para a prevenção da potencialidade criminógena das pessoas em estado perigoso. É necessária a prática de uma infração penal para a imposição de uma medida de segurança (NúÑEZ, María Elena. La peligrosidad. In: CovELLI, José Luis et al. Imputabilidad y capacidad de culpabilidad: perspectivas médicas e jurídico-penales. Buenos Aires: Dosyuna, 2009. p.131-133).

${ }^{297}$ SILVA, Aurélia Carla Quiroga; GOMES, Francisco de Assis Cabral. A cessação da periculosidade e a aplicabilidade da medida de segurança por prazo indeterminado sob as óticas constitucional e penal. Revista Direito e Liberdade, Mossoró, v. 10, n. 1, p. 61-63, jan./jun. 2009.

${ }^{298}$ Em comparação com a redação original do Código Penal de 1940, foram reduzidas aos limites mínimos as hipóteses de periculosidade presumida (DOTTI, op. cit., p. 317-320).

${ }^{299}$ SILVA; GOMES, op. cit., p. 61-63.

300 À absolvição que é seguida da imposição de medida de segurança, dá-se o nome de absolvição imprópria, pois, apesar da inexistência de um crime, ao agente é imposta coercitivamente uma medida de segurança (CARVAlHo, S., 2013, p. 500-501).

${ }^{301}$ CARValho, S., op. cit., p. 502.
} 
a aplicação provisória desta sanção desde a reforma do Código Penal, motivo pelo qual não se aplicam mais as disposições dos artigos 378 a 380, do Código de Processo Penal ${ }^{302}$.

Verificada a cessação de periculosidade, através de perícia após o prazo mínimo da medida de segurança ${ }^{303}$, ou a qualquer tempo, caso o juiz da execução determine, conforme o artigo 176, da Lei de Execução Penal, extingue-se a medida ${ }^{304}$.

\subsubsection{Das diferenças entre penas e medidas de segurança}

Apesar de a pena e a medida de segurança ser consequências jurídicas impostas após a prática de um fato típico e antijurídico, remanescem algumas diferenças entre elas, tais como o fundamento, o destinatário, a duração e a finalidade ${ }^{305}$.

Como já observado acima, o fundamento para a aplicação das penas e das medidas de segurança é uma das primeiras diferenças que se extrai delas.

Enquanto as penas são fundamentadas na culpabilidade do réu, a medida de segurança é imposta tendo em vista a periculosidade do agente. As penas são impostas de acordo com a gravidade do delito, sendo que as medidas de segurança são executadas enquanto perdurar a periculosidade do agente.

\footnotetext{
$\overline{302}$ DOTTI, 2001, p. 317-320.

303 Desse prazo mínimo, pode-se computar a detração, prevista no artigo 42, do Código Penal, para que se antecipe a realização do exame de cessação de periculosidade (NuCCI, Guilherme de Souza. Manual de direito penal. 9. ed. São Paulo: Revista dos Tribunais, 2013. p. 600-601).

${ }^{304} \mathrm{O}$ exame para verificar a cessação da periculosidade deve ser realizado anualmente, após o prazo mínimo da medida de segurança. No entanto, no Brasil, o atraso médio para realização desse exame é de 32 meses. Ainda, das medidas de segurança que já constavam, em 2011, a realização desse exame, em $28 \%$ dos casos, a periculosidade já havia cessado e $7 \%$ já tinha a sentença de desinternação (DINIZ, Débora. A custódia e o tratamento psiquiátrico no Brasil: censo 2011. Brasília: Letras Livres/ UNB, 2013. p. 44-56).

${ }^{305}$ QUEIROZ não concorda com tal distinção, pois acredita que não há diferença ontológica alguma entre penas e medidas de segurança, pois a medida de segurança não é só baseada na periculosidade do agente, tendo em vista que concorrem todos os pressupostos de punibilidade, sendo inadmissíveis medidas de segurança prédelituais. Ainda, a pena e a medida de segurança têm por finalidade a proteção subsidiária de bens jurídicos relevantes. A distinção estaria apenas nas consequências, se sujeito a pena ou medida de segurança, atendendo-se a critério de pura conveniência político-criminal ou de adequação (QUEIROZ, P., 2005, p. 15-16); FRAGOSO também aproxima a pena e a medida de segurança em sua justificação (proteção de bens jurídicos), fundamentação (prevenção de práticas criminosas) e por serem medidas de defesa social (FRAGOSO, 2004, p. 496-497).
} 
Isto em razão dos destinatários delas serem diferentes. Como já visto, a lei faz diferenças entre os imputáveis e os inimputáveis. A pena é aplicada para os primeiros e as medidas de segurança são aplicadas para estes, em razão da ausência de culpabilidade ${ }^{306}$.

Em decorrência desta diferença, distingue-se também a finalidade dessas consequências jurídico-penais.

A finalidade retributivo-preventiva é atribuída à pena criminal, de acordo com o artigo 59, do Código Penal. Já às medidas de segurança é atribuída apenas a finalidade preventiva, pois, tendo em vista que o agente é inteiramente incapaz de entender o caráter ilícito do fato ou de determinar-se conforme esse entendimento, não há por que retribuir a ação praticada por ele.

Percebe-se, desta forma, que as penas criminais são aplicadas visando o passado, ou seja, a conduta praticada pelo agente; já as medidas de segurança são aplicadas visando o futuro - o tratamento, a cura, a cessação da periculosidade. Neste caso, o passado (a prática da infração) é apenas um pressuposto para a aplicação da medida de segurança ${ }^{307}$.

Assim, a medida de segurança atua com fins de prevenção especial ${ }^{308}$, com o objetivo de evitar novas lesões a bens jurídicos penalmente relevantes e conferir ao inimputável um tratamento para que ele possa se reintegrar à sociedade cessada a sua periculosidade $^{309}$.

Tenta-se, com a medida de segurança, proteger a sociedade frente a futuros delitos, alcançando essa meta através de efeitos ressocializadores sobre a pessoa do autor do

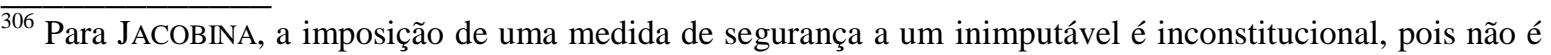
possível aferir culpa do inimputável e ela se dá após uma sentença penal absolutória, contrariando, desta forma, o inciso LVII, do artigo $5^{\circ}$, da Constituição Federal, sendo, portanto, caso de responsabilidade penal objetiva. Ademais, considera que impor um tratamento a alguém, contra a sua vontade, sem prazo definido, é uma medida estritamente punitiva (JACOBINA, Paulo Vasconcelos. Direito penal da loucura: medida de segurança e reforma psiquiátrica. Brasília: ESMPU, 2008. p. 95-99).

${ }^{307}$ PANCHERI, 1997, p.106.

${ }^{308}$ Costa JR., 1963, p. 140.

${ }^{309}$ Conforme previsão do artigo $1^{\circ}$, da Lei de Execução Penal.
} 
injusto penal $^{310}$. Assim, a medida de segurança é essencialmente preventiva, consubstanciando-se em segregação hospitalar, assistência, tratamento, custódia, reeducação, vigilância, com o objetivo de neutralizar a periculosidade para impedir a prática de novos ilícitos $^{311}$.

No entanto, também pode ser atribuída à medida de segurança a finalidade de prevenção geral negativa, para evitar reações públicas ou privadas arbitrárias contra o criminoso inimputável $^{312}$. A imposição da medida de segurança evitaria o sentimento de impunidade que pode ser gerado na sociedade em relação ao inimputável, ocasionando reações contra ele.

Contudo, na maneira que é regulada, a medida de segurança não pode ser confundida com impunidade, pois, dependendo do diagnóstico, o réu corre o risco de não ter mais alta, pelo menos não no prazo informado ${ }^{313}$.

Isto porque, da última diferença restante entre penas e medidas de segurança, esta é caracterizada pela indeterminação de seu prazo de duração. Enquanto o juiz determina a quantidade de pena ao imputável na sentença condenatória, a medida de segurança tem como termo final a cessação da periculosidade do réu; ou seja, pode perdurar durante toda a vida da pessoa submetida a ela.

\footnotetext{
${ }^{310}$ Costa, Álvaro Mayrink da. Medidas de segurança. In: LimA, Marcellus Polastri; RIBEIRO, Bruno de Morais (Coord.). Estudos criminais em homenagem a Weber Martins Batista. Rio de Janeiro: Lumen Juris, 2008. p. 3-6.

${ }^{311}$ LEVORIN, Marco Polo. Princípio da legalidade na medida de segurança: determinação do limite máximo de duração da internação. São Paulo: Juarez de Oliveira, 2003. p. 161-164.

312 QUEIROZ, P., 2005, p. 15-16. Para ARAÚJO, a medida de segurança harmoniza a impossibilidade de se punir um ato praticado por alguém que não possui consciência de seus atos e a necessidade de uma resposta estatal efetiva para os fatos típicos e antijurídicos cometidos por essas pessoas, para evitar o sentimento de impunidade, que pode levar ao fomento de vinganças, pois é disseminada ideia de impunidade (ARAúso, Fábio Roque da Silva. Prazos (mínimo e máximo) das medidas de segurança. Revista Magister de Direito Penal e Processual Penal, Porto Alegre, v. 4, n. 22, p. 55-57, fev./mar. 2008).

${ }^{313}$ JACOBINA, 2008, p. 115-117.
} 


\subsubsection{Espécies de medida de segurança}

Há, no ordenamento jurídico, duas espécies de medida de segurança: a internação em hospital de custódia e tratamento psiquiátrico e o tratamento ambulatorial.

Aos inimputáveis que cometem uma infração penal é aplicada, ao invés da pena, uma medida de segurança, que, conforme o artigo 96, do Código Penal, pode consistir em uma medida detentiva, que é a internação em hospital de custódia e tratamento psiquiátrico ou, à falta deste, em outro estabelecimento adequado ${ }^{314}$; ou em uma medida restritiva, que é a sujeição a tratamento ambulatorial.

A determinação da modalidade de tratamento ao inimputável é feita de acordo com a pena abstratamente cominada ao injusto penal praticado por ele - se detenção ou reclusão.

Conforme o artigo 97, do Código Penal, se o fato for punido com reclusão, o juiz, ao aplicar a medida de segurança, determinará a internação do agente em hospital de custódia e tratamento psiquiátrico. Contudo, se o fato for punido com detenção, o inimputável poderá ser submetido a tratamento ambulatorial, se as condições pessoais assim indicarem $^{315}$.

Em qualquer uma das duas espécies de medida de segurança, o prazo mínimo de duração da medida será imposto pelo juiz, podendo ser de 1 (um) a 3 (três) anos ${ }^{316}$, e o

\footnotetext{
$\overline{314}$ A falta de vaga em hospital de custódia e tratamento psiquiátrico não justifica o recolhimento em prisão, sob pena de grave violação ao devido procedimento da execução penal e intolerável coação ilegal (DOTTI, 2001, p. 320-324).

315 RoESlER, Cláudia Rosane; LAGE, Leonardo Almeida. A argumentação do STF e do STJ acerca da periculosidade de agentes inimputáveis e semi-imputáveis. Revista Brasileira de Ciências Criminais, São Paulo, v. 21, n. 105, p. 16-20, nov./dez. 2013.

${ }^{316}$ Estabelecer prazo mínimo para a medida de segurança vai de encontro com os fundamentos e objetivos almejados por ela. O laudo que atesta a inimputabilidade no processo penal não alude sobre lapso temporal necessário ou indicativo à cura da enfermidade, e as avaliações periódicas para verificar a cessação da periculosidade só são feitas após o término do prazo mínimo fixado. Isso demonstra, ainda, uma concepção retributiva, pois os prazos mínimos são fixados pelo julgador, equivocadamente, com base na gravidade abstrata do delito (ARAÚJo, 2008, p. 64-66). Em sentido contrário, a fixação de um prazo mínimo para a medida de segurança pode se justificar numa presunção legal da duração da periculosidade, pois a medida de segurança também tem por finalidade a proteção de bens jurídicos (BRANDÃo, Nuno. Limites de duração da
} 
prazo máximo será indeterminado, perdurando enquanto não for constatada a cessação da periculosidade do agente, a teor do parágrafo primeiro, do artigo 97, do Código Penal.

A cessação da periculosidade deverá ser averiguada por perícia médica, que, após o prazo mínimo da medida de segurança, deve ser realizada anualmente, ou a qualquer tempo, se assim determinar o juiz da execução, conforme disciplina do parágrafo $2^{\circ}$, do artigo 97, do Código Penal.

Nota-se que, mesmo que os profissionais da área médica indiquem ao inimputável tratamento ambulatorial, ele pode ser internado em decorrência da espécie de pena criminal cominada à infração praticada, o que pode comprometer a sua saúde, ao invés de auxiliá-lo em sua recuperação ${ }^{317}$.

É retirada, desta forma, do juiz a aferição em concreto da efetiva periculosidade do agente. Esta só pode ser feita quando o inimputável comete fato abstratamente punido com detenção, quando o juiz pode escolher, após a análise das circunstâncias do caso, se aplica tratamento ambulatorial ou não, motivando sua decisão ${ }^{318}$.

Apesar da distinção entre penas e medidas de segurança, há uma confusão entre esses dois institutos. Como é possível perceber, o tratamento oferecido na medida de segurança - ambulatorial ou internação - depende não do quadro clínico do agente, e sim do tipo penal e da pena que lhe seria imposta por conta desse tipo penal. Essa lógica punitiva tradicional é aplicada tacitamente às medidas de segurança ${ }^{319}$.

Assim, apesar de a periculosidade ser o fundamento da medida de segurança, e esta não se relacionar com as penas, o ordenamento dá importância à pena abstratamente

medida de segurança de internamento: acordão do Supremo Tribunal de Justiça de 12 de abril de 2000. Revista Portuguesa de Ciência Criminal, Coimbra, v. 10, n. 4, p. 624-628, out./dez. 2000).

317 SouZA, José Francisco Fischinger Moura de. Internação: substituição por tratamento ambulatorial: admissibilidade. Revista Síntese de Direito Penal e Processual Penal, Porto Alegre, v. 3, n. 17, p.58-61, dez./jan. 2003.

318 ARAúJo, Fábio Roque da Silva. Medida de segurança: caráter residual da internação. Revista IOB de Direito Penal e Processual Penal, Porto Alegre, v. 10, n. 57, p. 7-10, ago./set. 2009.

${ }^{319}$ SÁ; ALVES; ZIMMARO, 2013, p. 11-12. 
cominada à infração cometida pelo inimputável para determinar a espécie de medida de segurança que será imposta.

A regressão do tratamento ambulatorial para internação em hospital de custódia e tratamento psiquiátrico é admissível, conforme o artigo $97, \S 4^{\circ}$, do Código Penal e artigo 184, parágrafo único, da Lei de Execução Penal, nos casos que o agente revelar incompatibilidade com a primeira medida. Contudo, não há previsão legal para a progressão; ou seja, para o agente passar da internação para o ambulatório.

A desinternação ou a liberação do inimputável será sempre condicional, devendo ser restabelecida a medida de segurança se o agente, antes do decurso de 1 (um) ano, praticar fato indicativo da persistência da periculosidade, conforme artigo $97, \S 3^{\circ}$, do Código Penal.

Transcorrido esse prazo, ocorre a revogação da medida de segurança do inimputável.

3.1.3. Hipóteses de aplicação das medidas de segurança

A primeira previsão para aplicação da medida de segurança está nos artigos 26 e 97, do Código Penal, que tratam dos inimputáveis. Prevê o artigo 26 que é isento de pena aquele que, por doença mental ou desenvolvimento mental incompleto ou retardado, era, ao tempo da ação ou da omissão, inteiramente incapaz de entender o caráter ilícito do fato ou de determinar-se de acordo com esse entendimento.

Adotou o legislador o critério biopsicológico para determinar os agentes que são inimputáveis e que serão, presumidamente, tratados como perigosos pela lei, a necessitar do tratamento oferecido pela medida de segurança. 
Assim, os juízes não têm discricionariedade para deixar de aplicar ao inimputável uma medida de segurança, mesmo que ele não demonstre ser perigoso no momento da internação, tendo em vista que essa é presumida ${ }^{320}$.

Em seguida, no parágrafo único, do artigo 26, e no artigo 98, ambos do Código Penal, encontra-se a previsão de aplicação da medida de segurança aos semi-imputáveis, em substituição à pena privativa de liberdade.

$\mathrm{O}$ artigo 26, parágrafo único, determina que, a pena pode ser reduzida de 1 (um) a 2/3 (dois terços), se o agente, em virtude de perturbação mental ou por desenvolvimento mental incompleto ou retardado, não era inteiramente incapaz de entender o caráter ilícito do fato ou de determinar-se de acordo com esse entendimento.

Caso este agente necessite de especial tratamento curativo poderá ter a pena privativa de liberdade imposta substituída por uma medida de segurança - internação ou tratamento ambulatorial, pelo prazo mínimo de 1 (um) a 3 (três) anos, conforme o artigo 98, do Código Penal.

Neste caso, o período de internamento não deve exceder o tempo fixado na sentença para o cumprimento da pena de prisão. Depois, se não houver cessado ainda a periculosidade, o juiz pode colocar o internado a disposição do juízo cível para as medidas de proteção recomendadas pela sua enfermidade ${ }^{321}$.

Terceira hipótese de aplicação da medida de segurança, novamente substitutiva da pena privativa de liberdade, é se no curso da execução desta pena sobrevier doença mental. Neste caso, esta é convertida para a medida de segurança, conforme artigos 41, do Código Penal, e 108, da Lei de Execução Penal.

Mas, essa conversão só é feita se o condenado estiver cumprindo pena privativa de liberdade. Caso esteja cumprindo pena restritiva de direitos ou multa, esta permanece

\footnotetext{
$\overline{{ }^{320} \text { ROESLER; LAGE, }}$ 2013, p. 19-20.

${ }^{321}$ DotTI, 2001, p. 313.
} 
suspensa, pois o artigo 52, do Código Penal, não sujeita o inimputável a qualquer forma de sanção, nestes $\operatorname{casos}^{322}$.

Na hipótese de sobrevir doença mental no curso do cumprimento da pena privativa de liberdade, o prazo de duração da medida de segurança é o tempo restante da pena de prisão $^{323}$.

Assim, o tempo de duração da medida de segurança substitutiva, seja a prevista no artigo 41, ou a prevista no artigo 98, ambos do Código Penal, não pode ultrapassar o tempo determinado para o cumprimento da pena privativa de liberdade anteriormente imposta ${ }^{324}$, mas admite-se a transferência do internado para hospital psiquiátrico comum após esse prazo.

3.2. Das garantias das medidas de segurança

Apesar das tentativas de negar à medida de segurança natureza penal, tentando darlhe uma natureza administrativa, é evidente o caráter penal dessa consequência jurídica, podendo ser classificada como uma espécie do gênero sanção penal, ao lado da pena ${ }^{325}$.

Todo tratamento ministrado na medida de segurança implica em privação ou restrição de direitos da pessoa, portanto inevitavelmente tem implicação nos direitos fundamentais pertencentes a ela, pelo que se revela o seu caráter aflitivo, tal como a pena $^{326}$.

Ainda, conforme o artigo 99, da Lei de Execução Penal, os hospitais de custódia e tratamento psiquiátrico estão inseridos no Título IV, desta lei, que trata dos

\footnotetext{
${ }_{322}$ DOTTI, 2001, p. 313.

${ }^{323}$ COSTA, A., 2008, p. 10-15. Se o agente for curado durante esse prazo, procede-se à reconversão (NUCCI, 2013, p. 599-600).

${ }^{324}$ SILVA; GOMES, 2009, p. 63-65.

${ }^{325}$ Entre outros, QUEIROZ, P., 2010, p. 437; NUCCI, op. cit., p. 591.

${ }^{326}$ LEVORIN, 2003, p. 5-10.
} 
estabelecimentos penais $^{327}$; e, em São Paulo, são vinculados à Secretaria de Administração Penitenciária, ficando os internados sob a jurisdição penal.

Apesar de serem, estes locais, estabelecimentos hospitalares, não pertencem ao Sistema Único de Saúde - SUS; e são regrados pela execução penal e seus princípios. Assim, não há como defender que a medida de segurança tem natureza estritamente sanitária, e não punitiva ${ }^{328}$.

Desta forma, as garantias existentes às penas, também devem ser estendidas às medidas de segurança, como forma de resguardar os direitos e a dignidade das pessoas submetidas a internamento em hospital de custódia e tratamento psiquiátrico ou tratamento ambulatorial $^{329}$.

As pessoas submetidas a medidas de segurança têm direitos próprios, como o do artigo 99, do Código Penal, mas não se pode negar a elas, no que couber, os direitos previstos para o preso, pois os artigos $3^{\circ}$ e 42, da Lei de Execução Penal, determinam que as regras em favor do preso também valem para os indivíduos submetidos a uma medida de segurança.

Isto porque a consideração humana é uma das exigências fundamentais do processo penal num Estado Democrático de Direito ${ }^{330}$. A dignidade da pessoa é um dos fundamentos da República, conforme o artigo $1^{\circ}$, inciso III, da Constituição Federal, e deve orientar todas as sanções previstas no ordenamento positivo, inclusive da medida de segurança.

Portanto, devem ser aplicadas às medidas de segurança as garantias hoje aplicadas às penas, em decorrência da dignidade humana e do princípio da humanidade, como, por

\footnotetext{
$\overline{327}$ Nota-se que em relação ao ambiente e infraestrutura material o artigo 99, da Lei de Execução Penal remete os hospitais de custódia e tratamento psiquiátrico ao modelo carcerário (CARVALHO, S., 2013, p. 506-507).

328 JACOBINA, Paulo Vasconcelos. Direito penal da loucura: medida de segurança e reforma psiquiátrica. Boletim dos Procuradores da República, Brasília, ano VI, nº 70, p. 18, abr. 2006.

${ }^{329}$ Para CARVAlHo, “(...) em face do caráter aflitivo das medidas de segurança, é fundamental que os direitos e garantias que constituem o estatuto jurídico dos imputáveis sejam ampliados aos portadores de sofrimento psíquico (...)" (CARVALHO, S., op. cit., p. 504).

${ }^{330}$ DOTTI, 2001, p. 314.
} 
exemplo, o respeito à integridade física e moral, previsto no artigo $5^{\circ}$, inciso XLIX, da Constituição Federal, e no artigo 40, da Lei de Execução Penal.

3.2.1. Do prazo indeterminado das medidas de segurança

Como visto, a medida de segurança perdura enquanto for constatada a periculosidade do agente, sendo, ainda, um de seus objetivos, proporcionar a harmônica integração social do internado.

No entanto, a adoção deste critério para a revogação da medida de segurança traz algumas implicações quanto à efetivação do princípio da humanidade, na face que proíbe a adoção de penas perpétuas e de longa duração, especialmente quando se trata da internação em hospital de custódia e tratamento psiquiátrico, onde o inimputável tem sua liberdade de locomoção totalmente restrita.

Uma delas tem relação com a possibilidade de cura da enfermidade mental que acomete o agente. Se não for possível, mesmo com o tratamento adequado, alcançar a cura da enfermidade, o agente pode permanecer internado até o fim de sua vida, pois não terá sua periculosidade cessada e não há outro critério legal que permite a desinternação. Além disso, o tratamento oferecido pela medida de segurança no regime de internação pode piorar o quadro clínico do doente ${ }^{331}$, não sendo um meio eficaz à cura.

Outra questão que deve ser avaliada é o conhecimento, por parte dos psiquiatras responsáveis pelo tratamento dos internados, do conceito de periculosidade e a confiabilidade dos laudos produzidos, pois, por receio de serem responsabilizados por novas lesões a bens jurídicos praticadas pelos internados, podem responder negativamente quando questionados sobre a cessação da periculosidade ${ }^{332}$.

\footnotetext{
$\overline{331}$ PEREIRA, Sarah Caroline de Deus. Reforma psiquiátrica versus sistema de justiça criminal: a luta pela efetividade dos direitos humanos ao louco infrator. Revista de Estudos Jurídicos UNESP, Franca, v. 16, n. 23, p.319-324, jan./jul. 2012.

${ }^{332}$ BARRETO, Djalma. O alienista, o louco e a lei. Petrópolis: Vozes, 1978. p. 106.
} 
O princípio da humanidade inibe qualquer lei infraconstitucional que tente criar reprimenda penal atentatória aos direitos fundamentais da pessoa, como, por exemplo, a que permite a aplicação de uma sanção perpétua ${ }^{333}$. É necessário que a pessoa privada de liberdade tenha uma esperança de ver-se livre, o que não ocorre na medida de segurança, onde as pessoas a ela submetidas ficam na mais absoluta ignorância no que tange à limitação de seus direitos ${ }^{334}$.

Ainda que se justifique a indeterminação das medidas de segurança em critérios de prevenção, estes devem ser limitados, pois não podem ficar acima das garantias constitucionais e das metas de reintegração social ${ }^{335}$. Toda intervenção estatal na vida do homem deve ser regrada e limitada.

A dignidade humana limita o poder estatal, na observância ao respeito à pessoa e a sua liberdade, exigindo um uso racional e humanitário do poder. Assim, não é possível a aplicação de medidas de segurança cruéis, humilhantes, infamantes, degradantes e perpétuas, tendo em vista que a perda da liberdade não pode redundar na perda da dignidade $^{336}$.

Dizer que a medida de segurança perdurará enquanto não houver cessado a periculosidade do agente não é suficiente para limitar a sanção, pois esta pode ser perpétua ou de longa duração.

Necessário ressaltar, ainda, que, diferente do que ocorre com as penas criminais, as pessoas internadas em hospitais de custódia e tratamento psiquiátrico não conseguem obter

\footnotetext{
333 VIEIRA, Vanderson Roberto. "Medidas de segurança" por tempo indeterminado (perpétuas): impossibilidade constitucional. In: Paula, Marco Aurélio Borges de; Magrini, Rachel de Paula (Coord.). Estudos de direito público. Campo Grande: Cepejus, 2009. p. 678-680.

${ }^{334}$ LEVORIN, 2003, p. 5-10.

${ }^{335}$ PANCHERI, 1997, p.109-111.

${ }^{336}$ LEVORIN, Marco Polo. Direitos humanos e medida de segurança. Boletim IBCCRIM, São Paulo, v. 12, n. 141, p.6-7, ago. 2004.
} 
a liberdade, ou parte dela, antes do término do cumprimento da medida, pois não têm direito a, por exemplo, livramento condicional e progressão de regime ${ }^{337}$.

O cálculo da prescrição também fica prejudicado. Para os semi-imputáveis, esse cálculo se dá sobre a pena reduzida fixada antes da substituição pela medida de segurança. Mas, para os inimputáveis, após o início da execução da medida, o poder punitivo estatal torna-se ilimitado, pois a medida deve durar até cessar a periculosidade do agente ${ }^{338}$.

Contudo, como o tempo faz desaparecer o interesse na repressão do agente também quando se trata de inimputabilidade, a jurisprudência tem adotado diversos entendimentos para o cálculo da prescrição da pretensão executória, já que a prescrição da pretensão punitiva é regulada pela pena abstratamente cominada ao crime ${ }^{339}$. É possível encontrar decisões que consideram que o cálculo da prescrição da pretensão punitiva deve ser feito pelo máximo da pena cominada abstratamente à infração praticada ${ }^{340}$, e também que o cálculo deve ser feito pelo período máximo de internação ${ }^{341}, 30$ anos, como se verá a seguir.

Apesar de não encontrar limite na culpabilidade, a duração da medida de segurança pode ser limitada pelos princípios da humanidade, legalidade ${ }^{342}$, proporcionalidade, e pelos demais princípios penais, inclusive pela disposição constitucional de proíbe a aplicação de penas perpétuas (artigo 5, inciso XLVII, alínea “b”, da Constituição Federal).

\footnotetext{
337 A desresponsabilização prevista no Código Penal para os inimputáveis acaba afastando os limites da intervenção punitiva estatal, retirando ou restringindo, a essas pessoas, diretos e garantias mínimas, que têm os imputáveis (CARVALHO, S., 2013, p. 520).

${ }^{338}$ LEVORIN, 2003, p. 221-222.

${ }^{339}$ RoSSETTI, Janora Rocha. Da prescrição da medida de segurança. Revista da Procuradoria Geral do Estado de São Paulo, São Paulo, n. 40, p. 187-196, dez. 1993. Para esta autora, a prescrição da pretensão executória deveria ser regulada pela pena mínima abstratamente cominada à infração praticada, como forma de não criar uma desigualdade imensa em relação aos imputáveis e semi-imputáveis.

${ }^{340}$ BRASIL. Superior Tribunal de Justiça. Recurso Ordinário em Habeas Corpus n ${ }^{\text {o } 33.638 / R J}$, da $6^{\text {a Turma, }}$ Rel.: Ministra Maria Thereza de Assis Moura, j. 05.08.2014, DJe 18.08.2014.

${ }^{341}$ BRASIL. Supremo Tribunal Federal. Habeas corpus $\mathrm{n}^{\mathbf{o}}$ 107.777/RS, da $2^{\mathrm{a}}$ Turma, Rel.: Ministro Ayres Britto, j. 07.02.2012, DJe 16.04.2012.

${ }^{342}$ Por acreditar que a medida de segurança tem natureza pedagógica e terapêutica, CERNICCHIARO defende que ela não é alcançada pelo princípio da legalidade (CERNICCHIARO, Luiz Vicente. Princípio da Legalidade. In: Cernicchiaro, Luiz Vicente; Costa JR, Paulo José da. Direito penal na Constituição. 3.ed. rev. e ampl. São Paulo: Revista dos Tribunais, 1995. p. 33-34). TOLEDO complementa esse entendimento, ao dispor que é apenas um dos desdobramentos do princípio da legalidade - a anterioridade - que não alcança a medida de segurança, tendo em vista o caráter terapêutico dela (TOLEDO, Francisco de Assis. Princípios básicos de direito penal. $5^{\text {a }}$ ed. $15^{\text {a }}$ tir. São Paulo: Saraiva, 2010. p. 40-42).
} 
O princípio da legalidade estabelece contornos rígidos para a limitação da liberdade da pessoa, conforme incisos II e XXXIX, do artigo $5^{\circ}$, da Constituição Federal, não podendo existir sanção penal indeterminada, pois seria uma violação a esse direito fundamental $^{343}$. A pessoa internada tem direito de saber a duração da restrição de seus direitos quando esta lhe é imposta.

Violações desse aspecto do princípio da humanidade são facilmente encontradas. No Brasil, em 2011, havia pessoas internadas em hospital de custódia e tratamento psiquiátrico há mais de 30 anos, sendo que duas delas foram submetidas à medida de segurança em razão do cometimento de tentativa de furto e homicídio culposo, o que demonstra clara desproporcionalidade entre o fato praticado e a medida de segurança imposta. $21 \%$ dos internados cumpriam medida de segurança a mais tempo do que a pena máxima abstratamente cominada ao crime ${ }^{344}$.

Em homenagem à dignidade humana e aos princípios constitucionais penais, não há justificativa, numa perspectiva garantista, para que tais sanções durem indefinidamente ${ }^{345}$.

Como já visto, em relação às medidas de segurança substitutivas, a duração será, no máximo, o prazo da pena privativa de liberdade anteriormente imposta, já que há quantificação da pena privativa de liberdade antes da imposição da medida de segurança.

Para esse grupo de pessoas, o paradigma adotado para a aplicação da pena foi a culpabilidade, e não a periculosidade, pois o agente possuía, quando cometeu a infração,

\footnotetext{
$\overline{343}$ Fragoso, 2004, p. 498; LEVORIN, 2003, p. 5-10.

${ }^{344}$ DINIZ, 2013, p. 56-57. LIRA relata um caso em que uma pessoa ficou mais de 60 anos internada cumprindo medida de segurança, mesmo com sua periculosidade cessada há 40 anos. Ainda, o juiz que extinguiu a medida de segurança determinou que o inimputável permanecesse internado no mesmo local onde havia passado os últimos 60 anos, pois já era uma pessoa com mais de 90 anos de idade e, no entender do magistrado, seria melhor que permanecesse onde "fez amigos, sorriu, chorou e viveu". Além do esquecimento do Estado, essa pessoa submetida a medida de segurança por 60 anos ainda deve se submeter a uma decisão judicial sem toque de humanidade, que, além de pressupor que o agente "sorriu" e "viveu" em um ambiente de degradação da dignidade da pessoa, ainda o manteve trancado na instituição, ao determinar que lá ele deveria continuar, mesmo cessada a medida de segurança (LIRA, Rafael. O Direito por quem o faz - Execução penal. Medida de segurança. Princípio da dignidade da pessoa humana. Morosidade da prestação jurisdicional. Ineficiência do estado. Constrangimento ilegal. Boletim IBCCRIM, São Paulo, n. 238, set. 2012).

${ }^{345}$ QUEIROZ, P., 2005, p. 15-16.
} 
parcial capacidade de entendimento do caráter ilícito de seu ato, e de determinação conforme esse entendimento ${ }^{346}$.

Em relação às medidas de segurança impostas aos inimputáveis, é necessário estabelecer um prazo máximo para a duração da sanção, em decorrência da vedação constitucional de previsão de penas perpétuas ${ }^{347}$, e tendo em vista, ainda, a proibição de penas de longa duração, consequência da adoção do princípio da humanidade das penas ${ }^{348}$.

No que tange ao prazo de duração máximo das medidas de segurança, há aqueles que defendem que o prazo máximo abstratamente cominado para o injusto penal praticado pelo imputável deve ser aplicado também à medida de segurança ${ }^{349}$, haja vista a proporcionalidade das sanções.

Outros se posicionam no sentido de que o limite máximo da sanção deve ser o previsto no artigo 75, do Código Penal, ou seja, 30 anos.

Nesse caso, o posicionamento é de que, após transcorrer o prazo de 30 anos, se ainda persistir a periculosidade, o agente deve ser transferido para hospital psiquiátrico comum $^{350}$, caso haja laudo médico atestando a necessidade do tratamento, passando a tutela da pessoa para o juízo cível ${ }^{351}$.

\footnotetext{
$\overline{346}$ ARAÚJO, 2008, p. 63-64.

${ }^{347}$ Em sentido contrário, há entendimento de que a medida de segurança deve perdurar enquanto o agente for perigoso, pois o propósito da medida de segurança é curativo e terapêutico (entre outros, BETTIOL, 1976, p. 280-281; NUCCI, 2013, p. 597).

348 Outra consequência benéfica ao réu se houvesse a determinação do prazo máximo, seria que a defesa não teria medo de alegar a inimputabilidade, propiciando uma individualização verdadeira à pena aplicada ao réu (PANCHERI, 1997, p.111).

${ }^{349}$ Entre outros, adotam esse entendimento, ZAFFARONI; PIERANGELI, 2009, p. 733-734; CINTRA JR., Dyrceu Aguiar Dias. Direitos humanos e saúde mental. In: Escritos em homenagem a Alberto Silva Franco. São Paulo: Revista dos Tribunais, 2003. p. 158-161; QUEIROZ, P., 2005, p. 15-16.

${ }^{350}$ Entre outros, adotam esse posicionamento, SILVA; GOMES, 2009, p. 68-69; ArAúJO, 2008, p. 59-61; COSTA, A., 2008, p. 18-19. ZAFFARONI e PIERANGELI, apesar de defenderem que a medida de segurança deve ter por limite o máximo abstratamente cominado para a infração praticada, também entendem que, após esse prazo, se necessário, o agente deve ser encaminhado para o juízo cível (ZAFFARONI; PIERANGELI, op. cit., p. 733-734).

351 Se o laudo médico indicar, o tratamento do semi-imputável também pode continuar em hospital especializado após o término do prazo da medida de segurança (ARAÚJO, op. cit., p. 63-64).
} 
Este foi o entendimento do Supremo Tribunal Federal, ao julgar o Habeas Corpus $\mathrm{n}^{\mathrm{o}} 84.219-4 / \mathrm{SP}^{352}$, onde se consolidou o entendimento deste tribunal de que o prazo máximo de duração das medidas de segurança é de 30 anos, em razão da proibição de penas perpétuas, e em face do artigo 75, do Código Penal. Após o término da medida, se necessário, o inimputável deve ser transferido para hospital psiquiátrico comum. Neste acórdão, o Supremo Tribunal Federal reconheceu, ainda, a natureza aflitiva da medida de segurança, o que faz com que as garantias penais aplicadas às penas criminais também se apliquem a elas ${ }^{353}$.

Percebe-se, com a adoção deste entendimento, que o risco de desinternar a pessoa que sofre de enfermidade mental não é aceito pela sociedade da mesma forma que é aceito em relação ao imputável, que sai da prisão mesmo que não demonstre que se readaptou à sociedade ${ }^{354}$.

Nesse entendimento, a impossibilidade da adoção da pena máxima cominada à infração praticada decorre do fundamento a medida de segurança, que é a periculosidade do agente, e não a culpabilidade e a gravidade em abstrato do crime ${ }^{355}$. Do contrário, a imposição da medida de segurança demonstraria, também, uma finalidade retributiva.

Findo estes prazos, o poder punitivo estatal não deveria mais intervir na liberdade individual do cidadão inimputável, pois, senão, violaria os seus direitos fundamentais, haja vista a sanção perpétua que poderia ser executada.

Outra forma, ainda, de fazer uma leitura conforme a Constituição Federal das medidas de segurança é aplicar a pena ao inimputável, como se culpabilidade tivesse, e

\footnotetext{
$\overline{352}$ BRASIL. Supremo Tribunal Federal. Habeas corpus $n^{\circ}$ 84.219-4/SP, Rel.: Ministro Marco Aurélio, j. 16.08.2005, DJ 23.09.2005.

${ }^{353}$ Já no Superior Tribunal de Justiça, não há entendimento consolidado, podendo ser encontradas decisões que dizem que não há prazo máximo de duração da medida de segurança, devendo seu termo final se dar ao cessar a periculosidade do agente, há decisões que consideram o prazo de 30 anos e outras que consideram a pena máxima abstratamente cominada à infração (ROESLER; LAGE, 2013, p. 40-41).

${ }^{354}$ PANCHERI, 1997, p.109-111. Os crimes cometidos por inimputáveis não são tão preocupantes quanto à delinquência comum, mas a sociedade teme o doente mental pela imprevisibilidade de suas condutas (CIA, Michele. Medidas de segurança no direito penal brasileiro: a desinternação progressiva sob uma perspectiva político-criminal. São Paulo: UNESP, 2011. p. 17-24).

${ }^{355}$ ARAÚJO, 2008, p. 59-61.
} 
depois substituir pela medida de segurança, para se ter parâmetros mínimos e máximos de duração da medida e para que seja possível a individualização da sanção ${ }^{356}$.

Como forma, ainda, de interromper a perpetuidade da medida de segurança, o Poder Executivo tem concedido, a cada ano, indulto para as pessoas, independentemente da cessação de periculosidade, que tenham suportado privação de liberdade, seja com internação ou com tratamento ambulatorial por período igual ou superior ao máximo da pena cominada à infração penal correspondente à conduta praticada, ou, no caso da medida de segurança substitutiva, prevista no artigo 183, da Lei de Execução Penal, por período igual ao remanescente da condenação cominada, como é possível observar no artigo $1^{\circ}$, inciso XII, do Decreto $\mathrm{n}^{\mathrm{o}} 8.172 / 2013^{357}$.

Concedido o indulto, é extinta a punibilidade, conforme os artigos 741, do Código de Processo Penal e 107, inciso II, do Código Penal.

Se não se estender as garantias da pena criminal às medidas de segurança, especialmente as que dizem respeito às limitações das penas, estar-se-á legitimando a prisão perpétua e desrespeitando a dignidade humana e o princípio da humanidade.

A medida de segurança por tempo indeterminado é uma clara violação dos direitos humanos fundamentais, indo de encontro, também, aos tratados e convenções internacionais, ratificados pelo Brasil, que vedam as penas perpétuas.

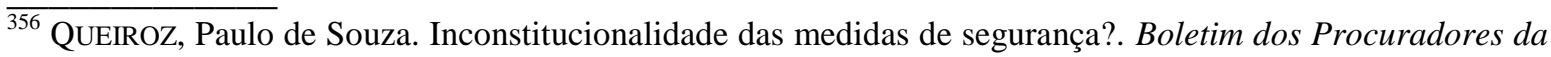
República, Brasília, ano VI, no 70, p. 23, abr. 2006. Esse sistema daria mais proporcionalidade entre a pena aplicada e o fato praticado, aproximando a pena que seria imposta ao imputável à do inimputável; respeitaria também o direito à igualdade de tratamento, inclusive para fins de contagem da prescrição e outros direitos decorrentes da execução criminal (CARVALHO, S., 2013, p. 515).

${ }^{357}$ Essa mesma disposição pode ser encontrada nos decretos concessórios de indulto dos demais anos, tais como os Decretos $n^{\circ} 7.873 / 2012$ (artigo $1^{\circ}$, inciso XI) e $n^{\circ} 7.648 / 2011$ (artigo $1^{\circ}$, inciso XI).
} 
3.2.2. O tratamento oferecido na medida de segurança e o objetivo de reinserção social

O artigo $1^{\circ}$, da Lei de Execução Penal, dispõe que um de seus objetivos é proporcionar condições para a harmônica integração social do internado. Esse objetivo se coaduna com a previsão do artigo 5.6, da Convenção Americana de Direitos Humanos, que determina que a pena privativa de liberdade deva ter por finalidade a readaptação social dos condenados, fim este que é um dos corolários do princípio da humanidade das penas.

Para alcançar esse objetivo de reintegração social do internado, a medida de segurança deve fornecer tratamento compatível à enfermidade mental da pessoa, de modo a cessar a sua periculosidade, para que ela possa retornar ao convívio social.

Mas, há um descompasso entre o que se considera tratamento terapêutico para doentes mentais e o tratamento oferecido pela medida de segurança.

Os hospitais de custódia e tratamento psiquiátrico não têm infraestrutura para oferecer o tratamento adequado aos doentes mentais; portanto, eles não têm chance de se curar e retomar a liberdade. Assim, os manicômios, antes de ser um tratamento àqueles que necessitam, é uma forma de proteção da sociedade em relação ao louco, inocuizando-o ${ }^{358}$.

Nestes locais, o tratamento dispensado aos pacientes, quando existente, geralmente é fundado em concepções não atualizadas, sem acesso a métodos terapêuticos modernos e medicação adequada $^{359}$. É comum a prática de tratamento coletivo, sem atenção individualizada a cada interno ${ }^{360}$. Ainda, os tratamentos oferecidos nos hospitais de

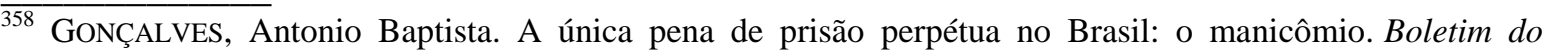
Instituto de Ciências Penais, Belo Horizonte, v. 5, n. 72, p. 2-4, ago. 2006. Para BETTIOL, a ideia de defesa social está em choque com toda concepção que considere o indivíduo como fim em si mesmo, pois elimina o indivíduo que não merece estar na sociedade (BETTIOL, 1976, p. 247-248).

${ }^{359}$ BARRoS, Carmen Silvia de Moraes. Aplicação da reforma psiquiátrica e da política de saúde mental ao louco infrator. In: BORGES, Paulo César Corrêa. Marcadores sociais da diferença e repressão penal. São Paulo: Cultura Acadêmica, 2011. p. 216-217.

${ }^{360}$ Tal situação foi constatada, por exemplo, no Hospital de Custódia e Tratamento Psiquiátrico "Prof. André Teixeira Lima", em Franco da Rocha, SP (BRASIL. Câmara dos Deputados. I Caravana Nacional de Direitos Humanos: uma amostra da realidade manicomial brasileira. Brasília: Centro de documentação e informação/ Coordenação e Publicações, 2000. p. 26).
} 
custódia e tratamento psiquiátrico são clinicamente questionáveis ${ }^{361}$, não sendo aptos a promover a cura da enfermidade mental que acomete o internado, impossibilitando, desta forma, o seu retorno à sociedade.

Há um uso abusivo de psicotrópicos, para o controle dos internados, e atuação exclusiva na doença em detrimento de outras dimensões do ser humano, que o portador de transtorno mental não as perde ${ }^{362}$. Dentro dos manicômios, as doenças se cronificam.

Conforme o artigo 43, da Lei de Execução Penal, a pessoa internada tem liberdade para escolher o médico responsável pelo seu tratamento. No entanto, na prática, não é o que ocorre. Dentro dos hospitais de custódia e tratamento psiquiátrico, o internado é tratado como um objeto, que não pode interferir em seu próprio tratamento ${ }^{363}$.

Os manicômios são instituições anacrônicas, onde oferece difícil tarefa aos médicos de curar num ambiente patogênico, onde a filosofia repressiva entra em choque com a terapêutica $^{364}$. Essas instituições são totais; ou seja, promovem a desconstrução da identidade da pessoa internada ${ }^{365}$. O internado acaba sendo despersonalizado; e piores são os efeitos quanto maior o tempo de internação.

O ambiente existente é prejudicial ao estado emocional do paciente, pois lhe tira a autonomia e a capacidade de decisão, além de ser isolado do mundo externo e de ter uma relação com a equipe médica de subordinação, sem um tratamento humano ${ }^{366}$.

É necessário salientar que sem um ambiente clínico favorável, o internado não conseguirá obter um tratamento condizente com suas necessidades ${ }^{367}$, impossibilitando a cessação de sua periculosidade, o que o deixará na instituição por longo período de tempo.

\footnotetext{
$\overline{361}$ CIA, 2011, p. 17-24.

362 CINTRA JR., 2003, p. 153-154.

363 MESSIAS, Simone Fagundes. Manicômio judiciário e a Lei de Execução Penal: garantias e violações. Revista Transdisciplinar de Ciências Penitenciárias, Pelotas, v. 4, n. 1, p. 44, jan./dez. 2005.

${ }^{364}$ PANCHERI, 1997, p.109-111.

${ }^{365}$ ROESLER; LAGE, 2013, p. 41-48.

366 CATAldo Neto, Alfredo; GAUER, Gabriel José Chittó. Uma leitura constitucional das internações psiquiátricas. In: FAYET JR, Ney; MAYA, André Machado (Org.). Ciências penais e sociedade complexa II. Porto Alegre: Nuria Fabris, 2009. p. 17-25.
} 
A desídia do Estado em relação ao tratamento médico oferecido durante a execução da medida de segurança ocorre, também, antes e depois da imposição desta, pois um tratamento adequado, no âmbito do Sistema Único de Saúde - SUS, bem como o efetivo acompanhamento, evitaria a prática do crime e a reincidência ${ }^{368}$, o que não permitiria a entrada e o retorno dessas pessoas a este ambiente.

Conforme o exposto, para que sejam alcançados os fins propostos à medida de segurança, é necessário encontrar o melhor tratamento da patologia do doente mental. Entretanto, necessário lembrar, ainda, que a lei não permitiu aplicar o tratamento ambulatorial para os delitos puníveis com reclusão, ainda que esse seja o tratamento recomendado pelos médicos e psiquiatras.

Nesses casos, mesmo que o tratamento ambulatorial seja a medida adequada e suficiente para o tratamento do inimputável, ele será submetido à internação, medida desproporcional e desnecessária para o caso.

Tendo em vista o princípio da individualização da pena, insculpido no artigo $5^{\circ}$, inciso XLVI, da Constituição Federal, a aplicação da medida de segurança, pelo juiz, deveria ser na medida exata - quantidade e qualidade - que proporcionasse a readaptação do indivíduo. Contudo, a medida de segurança não é individualizada, é generalizada à situação de periculosidade do agente ${ }^{369}$.

A medida de segurança também deveria ser individualizada, pois, tendo em vista a igualdade prevista no caput, do artigo $5^{\circ}$, da Constituição Federal, todos os direitos dos imputáveis devem ser estendidos aos inimputáveis e semi-imputáveis, principalmente no âmbito da execução da medida de segurança ${ }^{370}$.

\footnotetext{
${ }^{367}$ CATAldo Neto; GAUER, 2009, p. 11.

${ }^{368}$ BARROS, 2011, p. 214-215.

${ }^{369}$ DOTTI, 2001, p. 310.

${ }^{370}$ FERRARI, Eduardo Reale. As medidas de segurança criminais e sua progressão executória: desinternação progressiva. In: Shecaira, Sérgio Salomão (Org.). Estudos criminais em homenagem a Evandro Lins e Silva: criminalista do século. São Paulo: Método, 2001. p. 127.
} 
Assim, a aplicação do tratamento ambulatorial ao inimputável, apenas aos casos em que a infração praticada for abstratamente punível com detenção, não atende à finalidade para a qual o instituto foi criado e não trata a saúde como um dos direitos sociais elencados como cláusula pétrea pela Constituição Federal. Caso o médico, ao analisar o laudo de sanidade e o grau de periculosidade do agente, entre outras circunstâncias, entenda que o melhor tratamento é o ambulatorial e que este é suficiente, deveria ser aplicado o que fosse melhor ao paciente, pois não se pode aceitar simplesmente que o critério de escolha do tratamento esteja vinculado apenas ao tipo de delito cometido, sem a análise individual das circunstâncias do agente ${ }^{371}$. Essa obrigatoriedade pelo tratamento de internação também não se adequa à determinação de individualização das sanções, conforme artigo $5^{\circ}$, inciso XLVI, da Constituição Federal ${ }^{372}$.

Isso possibilitaria ao inimputável um tratamento adequado para a sua enfermidade, bem como a cessação de sua periculosidade e o consequente retorno ao convívio social, nos casos da aplicação da medida de internação. Sem a finalidade de reintegração social, a sanção penal perde seu caráter humano.

Além da ausência de tratamento adequado, a indeterminação do tempo de duração da medida de segurança também prejudica a reintegração social do inimputável a ela submetido.

A internação deve promover recuperação e ressocialização do paciente no meio familiar e social, mas, caso ela se prolongue desnecessariamente, se torna danosa e causa

\footnotetext{
${ }^{371}$ HASSELEIN, Karin Soares; CALDEIRA, Marconi. Medidas de segurança, tratamento ambulatorial: entre os limites de sua aplicação e o princípio da individualização da pena. Revista Síntese de Direito Penal e Processual Penal, Porto Alegre, v. 13, n. 78, p. 16-18, fev./mar. 2013. No mesmo sentido, NuCCI, 2013, p. 596; e o acórdão proferido no âmbito do Habeas Corpus nº 85.401/RS, do Supremo Tribunal Federal, que permitiu a aplicação de tratamento ambulatorial para caso em que a infração cometida era abstratamente punida com reclusão (BRASIL. Supremo Tribunal Federal. Habeas corpus no 85.401/RS, Rel.: Ministro Cezar Peluso, j. 04.12.2009, DJe 12.02.2010).

${ }^{372}$ Carvalho, S., 2013, p. 508.
} 
marginalização, exclusão e maus-tratos, conduzindo a um hospitalismo e dependência institucional, os quais o interno não irá conseguir superar e que poderiam ser evitados ${ }^{373}$.

A pessoa internada em hospital de custódia e tratamento psiquiátrico está destinada a ser doentes pelo resto da vida ${ }^{374}$, pois a carência de tratamento adequado, aliada à possibilidade de perpetuidade da medida, permite que ela permaneça internada até os últimos dias de sua vida, sem qualquer perspectiva de retorno à sociedade.

Ademais, a ausência de progresso no tratamento do enfermo mental desestimula os familiares a acompanhar o inimputável. Acaba ocorrendo um esquecimento progressivo do enfermo, afastando o indivíduo mais e mais da família e da sociedade ${ }^{375}$.

Não se pode perder de vista que a doença mental acarreta uma carga que pesa sobre todo o entorno familiar do paciente e sobre todos que o rodeiam ${ }^{376}$, por isso que se deve colocar a família junto com o tratamento de reintegração social do internado, apoiando-a durante e após o tratamento.

Nos estabelecimentos de internação, prevalece a ética da exclusão social do enfermo mental, tanto jurídica, quanto familiar, laboral, educacional e terapêutica ${ }^{377}$, o que não favorece a sua reintegração social e, ao contrário, condena o inimputável a permanecer no estabelecimento penal perpetuamente.

Assim, a ausência de tratamento adequado, a indeterminação do tempo de duração da medida de segurança e o desestímulo do acompanhamento familiar afastam a finalidade ressocializadora da medida de segurança, não atendendo à humanidade da sanção.

\footnotetext{
$\overline{373}$ PINTO, Ricardo Matías; RofranO, Gustavo Jorge. Aspectos jurídicos de la internación de pacientes mentales. In: Covelli, José Luis et al. Imputabilidad y capacidad de culpabilidad: perspectivas médicas e jurídico-penales. Buenos Aires: Dosyuna, 2009. p. 582-585.

${ }^{374}$ GONÇALVES, 2006, p. 2-4.

${ }^{375}$ GONÇALVES, op. cit., p. 2-4.

${ }^{376}$ PINTO; ROFRANO, op. cit., p. 579-580.

${ }^{377}$ CINTRA JR., 2003, p. 153-154.
} 


\subsubsection{Desinternação progressiva}

Podendo ser considerada uma nova modalidade para o cumprimento da medida de segurança, alguns hospitais de custódia e tratamento psiquiátrico passaram a adotar uma ala de desinternação progressiva, mesmo sem previsão legal, com o objetivo de reintegrar, aos poucos, o internado ao convívio social.

Este modelo tenta dar efetividade à finalidade de reinserção social do internado, oferecendo os meios e condições para que isso seja possível. Os inimputáveis submetidos à desinternação progressiva são cuidados por uma equipe multidisciplinar: médica e farmacológica, psicológica e social.

A desinternação progressiva é uma medida transitória entre situação de hospitalização em regime fechado e retorno ao meio social mais amplo. Ela proporciona aos indivíduos que aos poucos melhoram momentos de liberdade ${ }^{378}$, condições de reintegração comunitária, exteriorizada pela progressividade da execução, e resgate à autodeterminação e dignidade do cidadão delinquente doente, auxiliando-o na efetiva, gradativa e futura convivência sóciofamiliar ${ }^{379}$.

Nela, pacientes são liberados de forma gradativa, segundo seus avanços terapêuticos ${ }^{380}$. É devolvido ao interno o convívio social, através da promoção de, por exemplo, saídas para visitar a família, relacionamentos familiares e profissionais, trazendo concretos e excepcionais ganhos terapêuticos ${ }^{381}$.

É do exercício adequado da liberdade que depende a desinternação progressiva, que fomenta a autonomia e cidadania, ao mesmo tempo em que prolonga a fiscalização da unidade sobre o comportamento da pessoa ${ }^{382}$, pois a equipe de atendimento tem a possibilidade de supervisionar cuidadosa e criteriosamente as medidas terapêuticas

\footnotetext{
${ }^{378}$ CIA, 2011, p. 115-119.

${ }^{379}$ FERRARI, 2001, p. 127.

${ }^{380}$ CIA, op. cit., p. 115-119.

${ }^{381}$ FERRARI, op. cit., p. 128-129.

${ }^{382}$ CIA, op. cit., p. 160-165.
} 
propostas e acompanhar a evolução do desinternado em seu meio social, evitando-se, também, os efeitos deletérios, a médio e longo prazo, do hospitalismo ${ }^{383}$.

Esse modelo de cumprimento da medida de segurança também estimula a socialização e controle dos impulsos, e fomenta o trabalho que, quando possível, possibilita a criação de vínculos de coleguismo, amizade e intimidade ${ }^{384}$.

Os pacientes neste regime têm acesso a instrumentos cotidianos da vida sociofamiliar, como, por exemplo, talheres, têm espaços externos para locomoção, contato com o meio social, melhor relação com funcionários, tratamento nominal, visitas domiciliares assistidas. É possibilitado o retorno da vida autônoma e responsável, permitindo a reconstrução de sua própria identidade ${ }^{385}$.

Portanto, a desinternação progressiva é um modelo terapêutico que aprimora a compreensão, o manejo e a efetivação do tratamento, demonstrando que a internação não se aplica a todos os internos. No regime fechado, há um estado de dependência contínua do ambiente hospitalar, intensificando o distanciamento do meio sóciofamiliar ${ }^{386}$.

Consolidada em 1989, a desinternação progressiva em São Paulo é herança da alta progressiva aplicada no Rio Grande do Sul. Tem apoio do Poder Judiciário, que autorizou tal modalidade pela Portaria no 9/2003, da Vara das Execuções Criminais de São Paulo. Ressalta-se que não há previsão no ordenamento jurídico penal desta medida, mas que há respaldo judicial em decorrência dos benefícios que ela traz na execução da medida de segurança.

Foi instituída no Hospital de Custódia e Tratamento Psiquiátrico "Prof. André Teixeira Lima”, em Franco da Rocha, SP, que criou uma unidade de desinternação progressiva, funcionando também como hospital-noite, para os que trabalham externamente.

\footnotetext{
${ }_{383}$ SOUZA, 2003, p. 58-61.

${ }^{384}$ FERRARI, 2001, p. 128-129.

${ }^{385}$ CIA, 2011, p. 170-177.

${ }^{386}$ FERRARI, op. cit., p. 130.
} 
Nesta unidade, os inimputáveis lá internados recebem não apenas tratamento farmacológico, mas também de intuito ressocializador ${ }^{387}$, pois a simples prescrição de medicamentos apenas controla o quadro psicopatológico sem, contudo, interferir no processo de reintegração sociofamiliar ${ }^{388}$.

São realizadas visitas a familiares, é permitido trabalho externo, além de haver atividades dentro da instituição, como marcenaria e horticultura ${ }^{389}$. Caso o interno não respeite as condições da desinternação progressiva, ele retorna ao hospital de origem.

Para que seja possível a adoção desse modelo, tem que se ter em vista que a cura absoluta da doença ocorre muito raramente. Mas, na maior parte dos casos, com tratamento e medicamento adequados, acompanhamento profissional competente, os transtornos mentais são controláveis ${ }^{390}$, permitindo o retorno do interno ao convívio social. Para se alcançar esse controle, são necessárias tanto intervenções sobre o interno quanto sobre o seu meio ${ }^{391}$.

Há, neste caso, uma mudança na acepção da periculosidade, que não é mais concebida como exclusivamente endógena ao indivíduo. O interno é perigoso em determinadas situações e em certas condições, normalmente ligadas a sua história e a sua vivência social. A periculosidade passa a ser vista como fruto da interação do doente com o meio $^{392}$.

Após a desinternação, para a periculosidade continuar controlada, o interno deve continuar o tratamento pelo Sistema Único de Saúde - SUS. Toda desinternação deve ser

$\overline{387 \text { CIA, 2011, p. 17 }}-24$

${ }^{388}$ FERRARI, 2001, p. 131.

${ }^{389}$ CIA, op. cit., p. 17-24.

${ }^{390}$ BARROS, 2011, p. 216-217.

${ }^{391}$ CIA, op. cit., p. 157-158.

${ }^{392}$ Ibid., p. 158-160. 
assistida, para não abandonar as pessoas que necessitam de tratamento em outro ambiente, que não o hospital ${ }^{393}$.

Apesar dos ganhos terapêuticos e do retorno ao convívio social, a desinternação progressiva é limitada aos casos em que há respaldo da família e trabalho produtivo, o que impede muitos casos de serem transferidos para essa unidade ${ }^{394}$. Ainda, há critérios médicos seletivos para optar-se por aqueles que apresentam evolução no tratamento ${ }^{395}$.

Para que seja possível estender essa medida a todos os inimputáveis, deveria ser o tratamento a se adequar aos internados e não eles ao tratamento.

Assim, tendo em vista os benefícios trazidos por essa medida e sua adequação à dignidade humana e ao princípio da humanidade, é necessária uma reforma legislativa para incluir dispositivos sobre a desinternação progressiva e progressão ao tratamento ambulatorial no ordenamento jurídico, porque é imprescindível uma imediata adequação legal às novas e salutares modalidades terapêuticas, para não depender mais de improvisações judiciais ${ }^{396}$.

\subsubsection{Realidade manicomial}

Manicômios judiciários são normalmente conhecidos como os piores estabelecimentos psiquiátricos, onde o inimputável acaba tendo um tratamento mais aflitivo do que a pena criminal e muito mais penal do que terapêutico ${ }^{397}$. Os internados

\footnotetext{
${ }_{393}$ CINTRA JR., 2003, p. 157-158. Outro exemplo de acompanhamento para o retorno ao convívio social dos inimputáveis é o Programa de Atenção Integral ao Louco Infrator - PAILI/GO, que é um exemplo de trabalho realizado na desinternação progressiva de pessoas internadas em hospitais de custódia e tratamento psiquiátrico. Ele tem por objetivo fornecer um acompanhamento jurídico e psicossocial, fazendo a mediação entre justiça, saúde e sociedade, promovendo todas as etapas necessárias para o tratamento adequado e possibilitando aos inimputáveis outro destino que não o confinamento perpétuo em manicômios (SILVA, Martinho Braga Batista e. O desafio colocado pelas pessoas em medida de segurança no âmbito do SUS: a experiência do PAILI-GO. MPD Dialógico: Revista do Movimento Ministério Público Democrático, São Paulo, v. 8, n. 36, p. 32-33, 2012).

${ }^{394}$ PANCHERI, 1997, p. 111-112.

${ }^{395}$ FERRARI, 2011, p. 128.

396 Ibid., p. 132-133.

${ }^{397}$ FraGOSO, 2004, p. 496; CINTRA JR., op. cit., p. 158-161.
} 
ficam trancados em celas com rigor de cunho repressivo ${ }^{398}$, o que acaba cronificando a doença deles.

Como já visto, o hospital de custódia e tratamento psiquiátrico enclausura o louco infrator, submetendo-o a um tratamento clinicamente questionável e afastando-o da família e da sociedade, não tendo a menor acuidade com as especificidades que a doença mental exige do judiciário ${ }^{399}$.

Os enfermos mentais internados são vítimas de violações de seus direitos fundamentais, suportando tratamentos vexatórios, desumanos e degradantes. As más condições encontradas nos hospitais psiquiátricos afetam a saúde física e psíquica dos internados e acarretam a marginalização social dos que lá se encontram ${ }^{400}$.

Se estivessem na prisão, ao menos teriam alguns direitos que não são estendidos aos inimputáveis, como o livramento condicional e a progressão de regime, que permitem sair do regime fechado e recuperar parte da liberdade antes do término da pena.

Violações aos direitos dos internados e às finalidades da medida de segurança são encontradas em vários hospitais de custódia e tratamento psiquiátrico. No Hospital de Custódia e Tratamento Psiquiátrico de Manaus, por exemplo, que funcionava dentro da Cadeia Pública, 24 internos eram acomodados em 5 celas, sendo que 3 delas eram inabitáveis, pois eram escuras, com menos de $6 \mathrm{~m}^{2}$ e sem ventilação ${ }^{401}$.

No hospital de custódia de Pernambuco, havia 70 leitos para 336 internos, foram encontrados pacientes nus, que conviviam com seus dejetos, obrigados a dormir no chão, banheiros imundos, sendo que em alguns sequer havia água. Havia mais de 1 (um) mês que

\footnotetext{
$\overline{398}$ Costa, A., 2008, p. 6-10.

${ }^{399}$ PEREIRA, 2012, p. 316-319.

${ }^{400}$ PINTO; ROFRANO, 2009, p. 582-585.

${ }^{401}$ BRASIL. Câmara dos Deputados, 2000, p. 8.
} 
não era fornecido qualquer tipo de tratamento aos internos, pois não havia medicamentos disponíveis para fornecer a eles ${ }^{402}$.

Em geral, os internos não recebem tratamento, falta água, colchões, o local em que estão não propicia tratamento de reintegração social, e não há condições mínimas de higiene. As visitas íntimas são vedadas, bem como qualquer exercício da sexualidade, em qualquer circunstância. Essa vedação pode inibir a criação de laços afetivos que poderiam ser importantes para a cura e ressocialização da pessoa internada ${ }^{403}$.

A repressão sexual pode incitar, também, dentro desses estabelecimentos, o abuso e o estupro $^{404}$.

Essas condições de internamento encontradas constitui violação à dignidade do enfermo, o que torna a medida aplicada desumana e degradante.

Os laudos de exame para verificação da sanidade deveriam ser feitos em 45 dias, mas a média do tempo de espera por este documento no Brasil é de 10 meses. Em 2011, havia pelo menos 700 pessoas internadas em hospital de custódia e tratamento psiquiátrico aguardando este laudo, ou uma decisão sobre ele ${ }^{405}$. Ou seja, essas pessoas internadas, ainda não tinham decretada medida de segurança contra elas, nem tinham sido declaradas inimputáveis ainda ${ }^{406}$, porém já estavam inseridas num hospital de custódia e tratamento psiquiátrico, com todas as suas características maléficas.

\footnotetext{
$\overline{402}$ BRASIL. Câmara dos Deputados, 2000, p. 9.

${ }^{403}$ CIA, 2011, p. 17-24.

${ }^{404}$ MESSIAS, 2005, p. 43.

${ }^{405}$ DINIZ, 2013, p. 37-44.

${ }^{406}$ Para a realização do exame de sanidade mental, o indivíduo pode perder a liberdade e ser internado em manicômio judiciário, sem qualquer condenação e com requisitos muito mais largos do que os da prisão provisória, preventiva ou temporária. A internação ocorre sem indicação de tratamento, e apenas para a realização do exame médico-legal, de natureza declaratória, mostrando o sentido segregador da legislação, que visa à proteção social. Não se pode perder de vista que o prazo, a princípio de 45 dias, corre enquanto a pessoa, suspeita de insanidade, está em instituição total, capaz de alterar a conduta e a disposição psicológica do réu. Como visto, esse prazo, na prática é muito maior, situação que agrava a saúde mental da pessoa internada. Tal situação poderia ser evitada se, por exemplo, esse exame passasse a ser realizado por hospitais vinculados ao Sistema Único de Saúde - SUS (JACOBINA, 2008, p. 117-123).
} 
Muitos pacientes são esquecidos nos manicômios judiciais e o tempo de internação acaba ultrapassando os 30 anos. O inimputável, que, na prática, acaba recebendo tratamento mais grave que o imputável, é institucionalizado, e não tem prazo para sair do hospital, onde permanece sem contato com a sociedade e a família ${ }^{407}$.

Dentro dos manicômios judiciários, ademais, não há atendimento da Defensoria Pública. A pessoa submetida a uma medida de segurança deveria sempre ser assistida por um advogado para assegurar que a internação não se prolongue mais que o indispensável, e que esta tenha por base as garantias constitucionais ${ }^{408}$, respeitando as suas finalidades.

Ninguém se lembra da existência do louco infrator. Eles não têm organização mínima para reivindicar direitos e não há ninguém que fale por eles. Muitos são pobres, miseráveis $^{409}$.

Assim, os manicômios violam o artigo $5^{\circ}$, inciso III, da Constituição Federal, pois é um tratamento desumano. Na realidade manicomial, a finalidade que se obtém é de prevenção especial negativa, sendo a medida dotada de efeito neutralizante, inocuizador ${ }^{410}$.

A execução das medidas de segurança no Brasil necessita de urgente reestruturação, a fim de melhorar tanto as condições físicas das instituições psiquiátricas quanto a qualidade do tratamento terapêutico dispensado, pois estas não têm correspondido nem ao mínimo que delas se espera ${ }^{411}$.

Conforme o artigo 67, da Lei de Execução Penal, compete ao Ministério Público a fiscalização da aplicação da medida de segurança. Assim, este órgão deveria ficar atento às condições dos hospitais penitenciários, para não permitir a institucionalização de um

\footnotetext{
$\overline{407}$ Essas constatações foram feitas pelo Conselho Nacional de Justiça em visita realizada em manicômios judiciais. Disponível em: <http://osm.org.br/osm/cnj-inicia-mutirao-para-levantar-irregularidades-emmanicomios-judiciais/>, acesso em 04.09.2014.

${ }^{408}$ PINTO; ROFRANO, 2009, p. 582-585.

${ }^{409}$ BARROS, 2011, p. 213.

${ }^{410}$ COSTA, A., 2008, p. 15-18.

${ }^{411}$ CIA, 2011, p. 17-24.
} 
tratamento desumano e degradante que atenta contra a dignidade da pessoa e o princípio da humanidade.

\subsubsection{Tratamento coercitivo}

Além de o tratamento oferecido nos hospitais de custódia e tratamento psiquiátrico não ser adequado às pessoas submetidas à medida de segurança, é necessário debruçar-se, também, sobre as espécies de tratamentos oferecidos, especialmente quando se trata da medida de internação.

Apesar de o tratamento dispensado aos internados ter que condizer com a dignidade da pessoa humana, fundamento da República, pois esta também prevalece para aqueles que têm sua capacidade de entendimento diminuída, este se mostra como um conjunto de práticas cruéis, que trata o internado como objeto, e que tenta modificar sua personalidade e interferir em sua integridade psíquica, enquanto deveria ser apenas a mera prevenção da reincidência por reforço dos padrões de comportamento, e controle da periculosidade $^{412}$.

A internação submete a pessoa a tratamento psiquiátrico obrigatório, com finalidade terapêutica e de proteção da sociedade, tendo em vista que, uma vez internado, o inimputável tem sua liberdade de locomoção restrita ${ }^{413}$. É-lhe imposto um tratamento, pois não existe um consentimento livre, válido e informado, e não há liberdade para recusá-lo, pois se o fizer, pode prolongar o internamento ${ }^{414}$.

As práticas adotadas impõe um tratamento médico forçado, que, aliado à institucionalização prolongada, provocam deterioração psíquica irreversível ${ }^{415}$. Ainda, o

\footnotetext{
$\overline{412}$ PANCHERI, 1997, p. $106-107$.

${ }^{413}$ COSTA, A., 2008, p. 10-15.

${ }^{414}$ PANCHERI, op. cit., p. 106-107.

415 MaiA Neto, Cândido Furtado. Aplicação de medidas de segurança aos enfermos mentais. MPD

Dialógico: Revista do Movimento Ministério Público Democrático, São Paulo, v. 8, n. 36, p. 30-31, 2012.
} 
processo terapêutico consiste em ampliar a dependência do indivíduo, fazendo-o perder a sua autodeterminação, para, supostamente, aumentar sua autonomia ${ }^{416}$.

Até a década de 1950, o tratamento comumente dispensado às pessoas internadas em manicômios consistia em banhos quentes e frios, além dos métodos físicos de tratamentos, tais quais: cadeira giratória e o eletrochoque.

Nos dias atuais, essa situação pouco se alterou: a utilização de medicação em larga escala começou na década de 1960 e perdura até os dias atuais ${ }^{417}$, e a ingestão forçada de medicamentos é considerada legítima ${ }^{418}$.

Práticas como a eletroconvulsoterapia, choque cardiazólico e insulínico, e psicocirurgias, que causem efeitos orgânicos irreversíveis, a título de tratamento de enfermidade mental, são ainda utilizadas ${ }^{419}$.

Assim, o tratamento oferecido aos inimputáveis nos hospitais de custódia e tratamento psiquiátrico também constitui prática cruel, em decorrência dos métodos utilizados, que interferem na integridade física e psíquica da pessoa, o que é vedado, em decorrência do artigo $5^{\circ}$, inciso XLIX, da Constituição Federal, e artigo 40, da Lei de Execução Penal.

\subsection{Reforma psiquiátrica}

Nas últimas décadas do século $\mathrm{XX}$, ganhou espaço no cenário psiquiátrico brasileiro o movimento antimanicomial, que buscou uma reforma psiquiátrica que pudesse substituir o modelo existente até então. Cobrou, também por políticas públicas mais

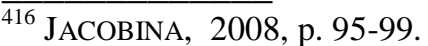

${ }^{417}$ PEREIRA, 2012, p.315-316.

${ }^{418}$ CIA, 2011, p. 178-180.

${ }^{419}$ BRASIL. Câmara dos Deputados, 2000, p. 6.
} 
adequadas e pela afirmação dos direitos dos doentes mentais, para que não se permita afastar os direitos fundamentais e sociais, e a cidadania deles ${ }^{420}$.

As ações desse movimento resultaram na Lei Federal no 10.216/2001, que deu nova abordagem legal quanto ao tratamento de doentes mentais.

Esta nova legislação concedeu vários direitos às pessoas que sofrem de transtorno mental, como é possível observar no artigo $2^{\circ}$, desta lei, deu contornos humanísticos ao tratamento clínico oferecido a eles ${ }^{421}$, e responsabilizou a família pela participação no tratamento do doente, conforme o artigo $3^{\text {o422 }}$.

Assegura-se a dignidade à pessoa do doente mental, pois dispõe sobre suas liberdades fundamentais e seus direitos básicos, em especial o direito a um sistema assistencial protetivo integrado à comunidade em que vive. Todo tratamento deve se desenvolver mediante seu consentimento informado, em ambiente condigno e adequado a sua condição ${ }^{423}$.

Conforme a reforma psiquiátrica, o doente deve manter vínculo com a família e a comunidade $^{424}$. Para atender ao princípio da humanidade das penas, o tratamento oferecido

\footnotetext{
${ }^{420}$ GONÇALVES, 2006, p. 2-4; PEREIRA, 2012, p. 316-319. Numa outra perspectiva, RAUTER alerta que, num Estado neoliberal, falar em desospitalização pode ser perversamente interessante para o Estado, pois este não quer mais ter essa função de tutela frente a essas pessoas. Prefere adotar novas estratégias de controle social, voltadas para espaços abertos, onde pode passar a representar um estado mínimo, que se desobriga da saúde, situação com a qual não pode se compactuar (RAUTER, Cristina. Manicômios, prisões, reformas e neoliberalismo. Discursos Sediciosos: crime, direito e sociedade, Rio de Janeiro, v. 2, n. 3, p. 72-75, 1997).

${ }^{421}$ Conforme o artigo $2^{\circ}$, inciso II, da Lei Federal $n^{\circ} 10.216 / 2001$ : É direito da pessoa portadora de transtorno mental "ser tratada com humanidade e respeito e no interesse exclusivo de beneficiar sua saúde, visando alcançar sua recuperação pela inserção na família, no trabalho e na comunidade".

${ }^{422}$ SÁ; Alves; ZimMARO, 2013, p. 11-12.

${ }^{423}$ CINTRA JR., 2003, p. 151-152.

${ }^{424}$ Conforme o artigo $3^{\circ}$, da Lei Federal n ${ }^{\circ}$ 10.216/2001: “É responsabilidade do Estado o desenvolvimento da política de saúde mental, a assistência e a promoção de ações de saúde aos portadores de transtornos mentais, com a devida participação da sociedade e da família, a qual será prestada em estabelecimento de saúde mental, assim entendidas as instituições ou unidades que ofereçam assistência em saúde aos portadores de transtornos mentais".
} 
nos hospitais de custódia deveria buscar a integração social do doente, e ser desprovido de caráter sancionatório $^{425}$.

Preconizou-se a subsidiariedade da internação, que só deve ser indicada quando os recursos extra-hospitalares se mostrarem insuficientes. Internações em instituições que se revestem de características asilares passaram a ser vedadas, como disciplina o artigo $4^{\circ}$, parágrafo $3^{\circ}$, da Lei Federal no 10.216/2001.

Houve o abandono desse tipo de instituição para adoção de tratamento ambulatorial e extra-hospitalar. As indicações de internação devem ser realizadas de maneira ética e responsável, tendo em vista os preceitos constitucionais, em especial quanto a direitos e garantias do ser humano e à dignidade da pessoa humana ${ }^{426}$.

De acordo com o artigo $4^{\circ}$, dessa lei, a internação passa a ter o caráter residual e o médico deve justificar a internação com laudo, dizendo que é o único recurso viável ao tratamento, conforme o artigo $6^{\circ}$, parágrafo único ${ }^{427}$.

A reforma psiquiátrica descartou a abordagem coativa, manicomial, unidisciplinar e repressora até então adotada. A medida de segurança, nessa nova visão, não pode mais se dar em benefício da sociedade, que se considera agredida e ameaçada pelo inimputável infrator $^{428}$.

O tratamento oferecido em instituições psiquiátricas deve passar a ser multidisciplinar, necessitando, a doença mental, de maior atenção da saúde pública e não do Direito Penal ${ }^{429}$.

Desta forma, toda indicação de internação deve ser feita com autorização médica e como último recurso, o que vai de encontro ao ordenamento penal, que impõe a medida de

\footnotetext{
$\overline{425}$ COSTA, A., 2008, p. 15-18.

${ }^{426}$ CATALDO NeTO; GAUER, 2009, p. 12-17.

${ }^{427}$ ARAÚJO, 2009, p. 12-15.

${ }^{428}$ JACOBINA, 2008, p. 133-138.

${ }^{429}$ PEREIRA, 2012, p. 316-319.
} 
segurança na modalidade de internação, ainda que não seja apropriada após a análise das circunstâncias pessoais do agente. É uma equipe multidisciplinar que deve dizer qual o tratamento indicado para cada pessoa individualmente considerada, respeitada sua dignidade, cidadania e titularidade de direitos ${ }^{430}$.

Deve ser necessário aferir casuisticamente a periculosidade e a viabilidade de recuperação do paciente mediante a adoção do internamento em hospital psiquiátrico, pois o tratamento aplicado ao inimputável deve ser o adequado, tendo em vista que a busca da reintegração social é uma das finalidades da existência da medida de segurança ${ }^{431}$.

Conforme os preceitos dessa lei, a escolha pela internação em hospital de custódia e tratamento psiquiátrico decorrente da imposição de uma medida de segurança não pode ser obrigatória, devendo a legislação apenas fixar balizas a serem observadas pelo julgador, mas não fixar de modo rígido sua conduta. As valorações em concreto devem ser reservadas ao julgador, senão a imposição da lei pode impedir o processo de reintegração social do agente, pois a internação pode agravar a patologia psíquica da pessoa ${ }^{432}$.

Devem-se substituir as internações hospitalares por um novo complexo de intervenções em que a preocupação com a pessoa dele é central ${ }^{433}$.

Essa lei põe em discussão o caráter terapêutico do internamento e o conceito de cura, não mais como devolução ao paciente de uma sanidade perdida, mas como trabalho permanente de construção de um sujeito ali onde parece existir apenas um objeto de intervenção terapêutica ${ }^{434}$. Assim, com esta reforma psiquiátrica, o enfermo ou deficiente

\footnotetext{
$\overline{430}$ BARROS, 2011, p. 214-215.

431 ARAÚJO, 2009, p. 12-15.

432 Ibid., p. 12-15.

${ }^{433}$ CINTRA JR., 2003, p. 155-156.

${ }^{434}$ ARAÚJO, op. cit., p. 12-15.
} 
mental é tratado como um sujeito de direito, que tem autonomia de intervir em seu próprio tratamento $^{435}$.

Antes o modelo hospitalocêntrico era baseado na exclusão social do doente, modelo que acarretou, desde sempre, graves violações aos direitos humanos ${ }^{436}$. Agora, esta lei incorpora os "Princípios básicos para a proteção de pessoas acometidas de transtorno mental e para a melhoria de assistência à saúde mental", da Organização das Nações Unidas $^{437}$.

Neste texto, resta claro que a desinternação da instituição psiquiátrica deve ser feita a critério do médico, e não do magistrado, conforme os itens $17.6^{438}$ e $20.1^{439}$.

Apesar da vigência desta lei, há mais de 10 anos, a reforma psiquiátrica e a política de humanização do tratamento do portador de transtorno mental ainda não alcançaram as pessoas submetidas à medida de segurança, em razão do conflito com o sistema jurídicoterapêutico-punitivo prisional dos hospitais de custódia e tratamento psiquiátrico ${ }^{440}$. Prevalece, ainda, a longa institucionalização, onde os internados devem se submeter ao tratamento imposto, sem questionar.

Entretanto, essa lei não fez diferenciação entre insanos autores ou não de delitos e conferiu a todos um tratamento digno e garantista ${ }^{441}$. O tratamento, também das pessoas

\footnotetext{
$\overline{435}$ CARVAlHO, S., 2013, p. 524-526. Este autor também conclui que, para tratar a pessoa como sujeito de direito, é necessário que ele seja visto como responsável pelos atos por ele praticados, pois negar essa responsabilidade é um ato de coisificação da pessoa.

${ }^{436}$ CINTRA JR., 2003, p. 151-152.

${ }^{437}$ Este texto dispõe sobre diversos princípios que devem ser seguidos pelos Estados ao disporem sobre os direitos das pessoas acometidas de doença mental. Logo no início deste texto, é ressaltado que todas as pessoas têm direito à melhor assistência disponível, e que as pessoas acometidas de transtorno mental, ou que estejam sendo tratadas como tal, deverão ser tratadas com humanidade e respeito à dignidade inerente à pessoa humana.

438 "Se, a qualquer momento, o profissional de saúde mental responsável pelo caso estiver convencido de que aquelas condições para a retenção de uma pessoa como paciente involuntário não são mais aplicáveis, este deverá determinar a alta dessa pessoa da condição de paciente involuntário".

439 "Este princípio se aplica a pessoas cumprindo sentenças de prisão por crimes, ou que estejam detidas no curso de investigações ou processos penais contra elas, e nas quais tenha sido determinada a presença de transtorno mental, ou a possibilidade e sua existência".

${ }^{440}$ PEREIRA, 2012, p. 319-324.

${ }^{441}$ Não há motivo para diferenciar o tratamento de uma pessoa de acordo com a via de acesso aos serviços públicos de saúde mental. Tanto os usuários comuns desses serviços quanto os que cometeram uma infração penal devem ter um tratamento regido pela lógica da desinstitucionalização (CARVALHO, S., op. cit., p. 530).
} 
submetidas a medidas de segurança, deve ser voltado às peculiaridades biopsicológicas do paciente, sendo indiferente o instituto jurídico que conduziu a pessoa a ele. Ademais, essa lei abrange o inimputável ao tratar da internação compulsória - única determinada pela justiça (artigo $6^{\circ}$, parágrafo único, inciso III), não admitindo tratamento diferenciado a eles $^{442}$.

Há uma incompatibilidade entre o Código Penal e a Lei Federal n 10.216/2001, pois o primeiro visa à segurança pública e o outro a concretização da igualdade e da saúde $^{443}$. Na lei que tratou da reforma psiquiátrica, a ideia de periculosidade cede lugar à preocupação com o transtorno mental e seu tratamento, oferendo aos doentes uma resposta desprovida de retributividade, ao tratar o indivíduo não como um criminoso, mas como alguém que necessita de tratamento médico ${ }^{444}$.

É incompatível os dispositivos do sistema penal que determinam a presunção de periculosidade do louco e seu tratamento em função do tipo de delito que cometeu, se apenado com reclusão ou detenção, baseado em prazos fixos e rígidos, com as normas sanitárias que determinam que o tratamento vise como finalidade permanente a reinserção social do paciente em seu meio, e que o internamento só será indicado quando os recursos extra-hospitalares mostrarem-se insuficientes ${ }^{445}$.

Não se pode mais conceber, também, prazos mínimos para o cumprimento da medida de segurança, ou considerá-los óbices intransponíveis à determinação da perícia médica para aferir cessação de periculosidade, pois, uma vez cessada a periculosidade, não subsistem razões que legitimem a internação, pois não tem utilidade terapêutica ${ }^{446}$. A manutenção de um prazo mínimo para o cumprimento da medida de segurança, ainda que cessada a periculosidade do agente, indica um sentido retributivo desta sanção aos inimputáveis ${ }^{447}$.

\footnotetext{
$\overline{442}$ BARROS, 2011, p. 214-215; QUEIROZ, P., 2010, p. 440.

${ }^{443}$ ROESLER; LAGE, 2013, p. 41-48.

${ }^{444}$ SÁ; ALVES; ZIMMARO, 2013, p. 11-12.

445 JACOBINA, 2006, p. 19.

446 ARAÚJO, 2008, p. 64-66.

${ }^{447}$ Carvalho, S., 2013, p. 515-516.
} 
Também, é necessário adequar a execução da medida de segurança com a reforma psiquiátrica moderna, em razão do descompasso entre a realidade manicomial brasileira e a Lei Federal $\mathrm{n}^{\mathrm{o}}$ 10.216/2001, que determina às pessoas internadas um tratamento com humanidade. Os avanços alcançados pela reforma psiquiátrica devem ser incorporados às práticas do sistema penal $^{448}$.

Da forma que são impostas e executadas as medidas de segurança, o doente mental infrator acaba sendo duplamente discriminado, pois é estigmatizado pela sua condição psiquiátrica e penal $^{449}$. Graças ao manicômio judiciário, os doentes mentais fazem parte da população psiquiátrica e penitenciária ao mesmo tempo, estando vulneráveis a violações de direitos humanos de diferentes ordens ${ }^{450}$, e adquirem, ainda, as características de institucionalização e de prisionização ${ }^{451}$.

Por isso que a medida de segurança deve ser minimamente aflitiva para o inimputável, pois encerram duas violências, hospital e cárcere.

A Lei Federal no 10.216/2001 deveria ser estendida e aplicada em sua integralidade às pessoas submetidas a medidas de segurança, pois ela estabeleceu um novo paradigma no que tange aos direitos das pessoas portadoras de doença mental, lançou novo olhar à loucura e substituiu a segregação pela desinstitucionalização e humanização do tratamento de portadores de transtorno mental ${ }^{452}$. O controle judicial das medidas de segurança deve se dar apenas quanto às garantias da pessoa, como, por exemplo, o limite máximo de intervenção curativa realizada. Excetuando esse controle, a intervenção terapêutica deve ser idêntica tanto para aquele que cometeu uma infração, quanto para o usuário comum do sistema de saúde psiquiátrico ${ }^{453}$.

\footnotetext{
${ }^{448}$ CARVAlHO, S., 2013, p. 530.

${ }^{449}$ CostA, A., 2008, p. 24.

${ }^{450}$ SILVA, M., 2012, p. 32-33.

${ }^{451}$ BARROS, 2011, p. 213.

452 Ibid., p. 214-215.

453 Carvalho, S., op. cit., p. 515-516. Para este autor, é possível até passar para o âmbito civil ou administrativo a responsabilização do portador de sofrimento psíquico, pois a forma como a Lei Federal $n^{\circ}$ 10.216/2001 estruturou a resposta jurídica ao ato lesivo praticado torna desnecessária qualquer intervenção penal.
} 
Caso não seja possível conciliar as leis penais e sanitárias, deve-se adotar nova solução para o grupo de pessoas que a medida de segurança se destina, com base no diálogo multilateral e interdisciplinar, como já vem ocorrendo com a desinternação progressiva, que evita que a internação se transforme em sanção perpétua ${ }^{454}$.

Só quando o ideal de desinstitucionalização chegar ao sistema penitenciário é que se poderá falar em efetivação da reforma psiquiátrica no país, pois, nos hospitais de custódia e tratamento psiquiátrico, continuam sendo mantidas presas milhares de pessoas com os mais variados transtornos mentais, sem qualquer tipo de tratamento ${ }^{455}$.

\footnotetext{
$\overline{454}$ JACOBINA, 2008, p. 133-138. O Conselho Nacional de Política Criminal e Penitenciária adotou a Resolução $\mathrm{n}^{\mathrm{o}}$ 4/2010, que dispõe sobre a adoção do modelo antimanicomial e das diretrizes da Lei Federal $\mathrm{n}^{\circ}$ 10.216/2001, no prazo de 10 anos, no que tange aos pacientes judiciários e execução das medidas de segurança. Há quem defenda que o tratamento psiquiátrico do louco infrator deveria se dar no âmbito da saúde pública e não do Direito Penal, para ser melhor do ponto de vista da dignidade humana e da intervenção mínima, e para ficar longe da estigmatização e dos efeitos degradantes que podem ser causados pela intervenção penal (JACOBINA, op. cit., p. 133-138; BARROS, 2011, p. 218-219; SÁ; ALVES; ZIMMARO, 2013, p. 11-12. Estes últimos autores ainda recordam que a intervenção do Direito Penal atualmente se justifica para conferir às medidas de segurança as mesmas limitações estatais que são conferidas às penas criminais. Mas, essas garantias são ilusórias, pois, no caso da duração máxima da medida de segurança, por exemplo, após o prazo máximo da medida, o agente é civilmente interditado, e permanece internado no mesmo estabelecimento, mas sob a tutela cível).

${ }^{455}$ BARROS, op. cit., p. 216-217.
} 


\section{CAPÍTULO 4. DAS MEDIDAS SOCIOEDUCATIVAS}

\subsection{A doutrina da proteção integral}

Na América Latina, até o início do século XX, a legislação de menores tinha caráter penal indiferenciado; ou seja, em geral, as legislações estabeleciam uma idade em que a criança era absolutamente incapaz, aos 7 (sete) anos, por exemplo, e, após essa idade, até os 18 anos, a pessoa era tratada da mesma forma que os adultos, aplicando-se apenas uma atenuação da pena, mas alojando-os nas mesmas instituições que os adultos ${ }^{456}$.

Superado o caráter indiferenciado, passou a predominar o caráter tutelar das legislações de menores, onde as crianças e adolescentes sofriam medidas assistenciais para superar a condição a qual se encontram, com conteúdo correcionalista. No Brasil, duas legislações se destacaram.

A primeira delas foi o Código de Menores, de 1927, instituído pelo Decreto Federal $n^{\text {o }}$ 17.943/1927, que não fazia distinção entre os menores infratores e os abandonados, ambos podiam ser submetidos a medidas de assistência constantes no código, e este estabelecia a responsabilidade penal aos 14 anos. A escolha da medida a ser adotada era discricionária, feita pelo juiz, sem quaisquer garantias processuais ao menor. Havia, desta forma, um sistema de controle social formal, com medidas institucionalizadoras, de caráter penal, aplicadas sem quaisquer garantias, evidenciando-se, ainda, um direito penal do autor $^{457}$, pois a medida não fundava-se, necessariamente, sobre a prática de um ato infracional.

Após, foi editada a Lei Federal nº 6.697/1979, conhecida como Código de Menores de 1979, cujos sujeitos da lei eram os menores em situação irregular - aqueles menores de

\footnotetext{
456 GARCÍA MÉNDEZ, Emilio. Adolescentes y responsabilidad penal: un debate latinoamericano. Revista Brasileira de Ciências Criminais, São Paulo, v. 12, n. 48, p. 230-232, mai./jun. 2004.

457 SheCAIRA, Sérgio Salomão. Sistema de garantias e o Direito Penal Juvenil. São Paulo: Revista dos Tribunais, 2008. p. 38-40.
} 
18 anos, privados de condições essenciais à saúde e instrução escolar, vítimas de maustratos ou castigos imoderados, em perigo moral, desassistidos juridicamente, com desvio de conduta ou autores de infração penal ${ }^{458}$. Assim, bastava estar em situação irregular justificar a submissão a uma medida tutelar, como a internação, ainda que não praticasse qualquer infração.

Nesta legislação, os menores de 14 anos eram considerados irresponsáveis; as pessoas entre 14 a 16 anos também eram consideradas irresponsáveis, mas havia um processo de apuração do qual poderiam resultar medidas de assistência; e os adolescentes entre 16 e 18 anos eram considerados responsáveis, sofrendo as penas do Código Penal, com redução de $1 / 3$ nas penas privativas de liberdade ${ }^{459}$.

Essas legislações eram marcadas pela subjetividade do juiz e pelo controle social, justificando reclusões com requisitos imprecisos, despidas de todas as garantias que uma medida de tal natureza deve necessariamente incluir. Com a doutrina da situação irregular, os desajustados sociais eram um mal a ser combatido, por isso se estruturou um modelo de ação correcional-repressivo com o objetivo de retirá-los do meio social, confinando-os em instituições totais, como o pretexto de recuperá-los e devolvê-los pacíficos à convivência social $^{460}$.

Concebendo um direito do menor fora dos marcos e limites do direito penal clássico, gerou-se durante décadas um sistema especial de controle, vigilância e contenção da infância e da adolescência, que encobriu a aplicação de penas de forma ampliada e ilimitada, para que o perigo que cercava os jovens e que neles se personificava fosse extinto, justificando, inclusive, medidas pré-delituais ${ }^{461}$.

\footnotetext{
458 SANTOS, Danielle Maria Espezim dos. O controle da natureza pedagógica das medidas socioeducativas. Revista da ESMESC: Escola Superior da Magistratura do Estado de Santa Catarina, Florianópolis, v. 19, n. 25, p. 48-52, 2012.

${ }^{459}$ NASCIMENTO, José Flávio Braga. Imputabilidade do menor sob a ótica criminológica. São Paulo: Juarez de Oliveira, 2007. p. 56-58.

${ }^{460}$ VolPI, Mario. O adolescente e o ato infracional. Revista do ILANUD, São Paulo, n. 14, p. 15-16, 23-25, 2001.

${ }^{461}$ SPOSATO, Karyna Batista. O direito penal juvenil. São Paulo: Revista dos Tribunais, 2006. p. 63-82.
} 
Os jovens eram estigmatizados pelo simples fato de serem menores, não possuírem família ou não frequentarem regularmente a escola. Reprimia-os, condenando-os pela ineficiência de um sistema que deveria garantir-lhes condições plenas para um desenvolvimento saudável ${ }^{462}$.

Desta forma, a situação irregular era identificada como traço de periculosidade em crianças e adolescentes pobres, o que permitia o exercício de situações controladoras e repressivas, encobertas pelo discurso da assistência social, que tentava neutralizar seu caráter sancionatório $^{463}$.

Concomitantemente à doutrina da situação irregular, surgem em âmbito internacional alguns textos que enunciavam princípios gerais para o direito das crianças e dos adolescentes, mas sem prever obrigações específicas aos Estados, como a Declaração de Genebra, adotada pela Sociedade das Nações, em 1924, que foi a primeira tentativa de elencar, em um mesmo texto, as condições fundamentais para a sobrevivência e desenvolvimento da criança, sendo a responsabilidade pela criança coletiva e internacional; e a Declaração dos Direitos da Criança, de 1959, que reconheceu a necessidade de proteção e cuidados específicos à infância, como consequência do reconhecimento de sua vulnerabilidade $^{464}$.

Apenas no fim do século XX surge uma nova doutrina que passa a dar um tratamento diferente às crianças e aos adolescentes, denominada doutrina da proteção integral.

\footnotetext{
$\overline{462}$ CASTRO, Ana Márcia de Souza. Alternativas ao jovem infrator. Revista do ILANUD, São Paulo, n. 12, p. 19-22, 1998.

${ }^{463}$ SPOSATO, 2006-b, p. 70-82

${ }^{464}$ MARTIN-ChEnUT, Kathia Regina. Adolescentes em conflito com a lei: o modelo de intervenção preconizado pelo Direito Internacional dos Direitos Humanos. Revista do ILANUD, São Paulo, n. 24, p. 81-86, 2003. As convenções tratadas no Capítulo 1 também trouxeram algumas disposições relativas aos direitos das crianças e dos adolescentes, como a Declaração Americana dos Direitos e Deveres do Homem, em seus artigos 6, 7 e 30; a Convenção Americana de Direitos Humanos, nos artigos 4.5, 5.5 e 19; a Declaração Universal dos Direito Humanos, que reconheceu que a infância tem direito a cuidados e assistência especiais, como, por exemplo, em seu artigo 26, que garante acesso à educação para a plena expansão da personalidade humana e o reforço dos direitos do homem e das liberdades fundamentais; e o Pacto de Direito Civis e Políticos, onde houve uma interpretação que levou ao reconhecimento de garantias penais e processuais no âmbito das legislações de menores, limitando o poder punitivo do Estado. A aplicabilidade das garantias penais, portanto, terá sempre lugar diante da afetação da liberdade individual ou da imposição de qualquer consequência criminal (SPOSATO, op. cit, p. 63-70).
} 
No Brasil, essa nova abordagem iniciou-se a partir da promulgação da Constituição Federal de 1988, que, em seu artigo 227, parágrafo $3^{\circ}$, inciso $\mathrm{V}$, estabeleceu que na aplicação de qualquer medida privativa de liberdade aos menores de 18 anos, dever-se-ia respeitar os princípios da excepcionalidade e da brevidade, e a condição peculiar de pessoa em desenvolvimento.

Surgem, também, novos textos internacionais que integram a doutrina das Nações Unidas de Proteção Integral à Infância.

O primeiro desses textos, adotados em 1985, são as Regras Mínimas das Nações Unidas para a Administração da Justiça, da Infância e da Juventude, também conhecida como Regras de Beijing, que prevê disposições detalhadas sobre a justiça da infância, que deve ser especializada e profissionalizada ${ }^{465}$, e que representa o ideal de direito penal juvenil, atribuindo à pena a função de prevenção de delitos, rejeitando as exigências de retribuição ao mal causado, e limitando a incidência do Direito Penal estritamente aos casos de necessária proteção dos cidadãos ${ }^{466}$.

Entre as disposições trazidas por essas regras, está o direito a um processo imparcial e justo, no item 14.1, os princípios da brevidade e excepcionalidade da internação, no item 19, e a separação dos jovens internados dos adultos, no item 26.3.

Um ano após a promulgação da Constituição Federal, em 1989, é adotada, pela Organização das Nações Unidas, a Convenção sobre os Direitos da Criança, tratado que teve a mais rápida e ampla aceitação da história ${ }^{467}$.

Esta convenção concluiu um processo de positivação dos direitos da criança e do adolescente na esfera internacional, dando a eles um papel ativo, de sujeitos de direito, que são credores de uma política de proteção integral, de cunho humanista ${ }^{468}$.

\footnotetext{
$\overline{465}$ MARTIN-CHENUT, 2003, p. 81-86.

${ }^{466}$ SPOSATO, 2006-b, p. 114-118.

467 Apenas Estados Unidos e Somália não a ratificaram. Contudo, alguns países se utilizam de reservas que torna essa Convenção quase que completamente ineficaz dentro de seu território (MARTIN-CHENUT, 2003, p. 81-86).
} 
Com os preceitos adotados por este texto, os Estados passam a distinguir, nas legislações de menores, os problemas de natureza social e penal, e atribuem aos adolescentes uma responsabilidade penal $^{469}$, de maneira específica, sendo esta responsabilidade o ponto de partida para considerá-los sujeitos de direito e para distinguir inimputabilidade e ausência de responsabilidade ${ }^{470}$.

Dentre os direitos trazidos por esta convenção está o melhor interesse da criança, no artigo $3^{\circ}$, o direito do adolescente infrator de ser tratado com humanidade e de ter sua dignidade respeitada, conforme o artigo 37, e o descabimento de imposição de medida socioeducativa em situações em que ao adulto não caberia imposição de pena. Ou o tratamento é mais favorável ao adolescente ou é igual ao dispensado ao adulto ${ }^{471}$.

Completando a doutrina da proteção integral à infância, tem-se as Diretrizes da Nações Unidas para Prevenção da Delinquência Juvenil, de 1990, também conhecida como Diretrizes de RIAD, que visou a promoção de uma política de integração social da infância e da juventude no intuito de prevenir a marginalização, a vitimização e a estigmatização do adolescente; e, do mesmo ano, As Regras Mínimas das Nações Unidas para a Elaboração de Medidas não Privativas de Liberdade, também conhecida como Regras de Tóquio, que representou a preocupação da comunidade internacional em proteger os jovens privados de liberdade, em virtude da vulnerabilidade dos mesmos aos maus-tratos e a toda forma de violação de direitos ${ }^{472}$.

Esse conjunto de regras internacionais não pretende uniformizar os sistemas jurídicos de todas as nações, mas sim harmonizá-los, estabelecendo certos limites que não

\footnotetext{
${ }^{468}$ VOLPI, 2001, p. 23-25.

${ }^{469}$ GARCÍA MÉNDEZ, 2004, p. 230-232.

470 Sposato, Karyna Batista. Gato por lebre: a ideologia correcional no Estatuto da Criança e do Adolescente. Revista Brasileira de Ciências Criminais, São Paulo, v. 58, p. 139-143, jan./fev. 2006.

${ }^{471}$ SARAIVA, João Batista Costa. Adolescente em conflito com a lei: da indiferença à proteção integral; uma abordagem sobre a responsabilidade penal juvenil. $3^{\mathrm{a}}$ ed. Porto Alegre: Livraria do Advogado, 2009. p. 100106.

${ }^{472}$ Martin-Chenut, 2003, p. 81-86.
} 
devem ser ultrapassados ${ }^{473}$. Ademais, deslegitimam por completo a doutrina da situação irregular, assentando a doutrina da proteção integral.

Assim, a doutrina da proteção integral se aplica a todas as crianças e adolescentes, que são vistos como titulares de direitos universalmente reconhecidos, e delineia normas a serem observadas no tratamento deles, como, por exemplo, que o papel de cada operador do direito deve ser bem delimitado, de modo a coibir arbitrariedades ${ }^{474}$.

Essa doutrina representa, também, uma mudança significativa nos fundamentos e princípios que norteiam o exercício do poder punitivo estatal diante da criminalidade juvenil, onde é considerado infrator apenas o adolescente que pratica fato previamente definido como crime ou contravenção penal, sendo que, no processo judicial, deve-se observar as garantias do devido processo legal, contraditório e ampla defesa, devendo, ainda, a criança receber tratamento específico de proteção, não sujeita à medida socioeducativa $^{475}$.

\subsection{O Estatuto da Criança e do Adolescente e o Direito Penal Juvenil}

Depois da promulgação da Constituição Federal de 1988 e da adoção das convenções citadas acima, em especial a Convenção sobre os Direitos da Criança, de 1989, o Brasil adota uma nova legislação de menores, substituindo o Código de Menores de 1979, já fundada sobre a doutrina da proteção integral, que é a Lei Federal nº 8.069/1990, conhecida como Estatuto da Criança e do Adolescente.

Esta lei regulamenta os artigos 227 e 228, da Constituição Federal, assegurando às crianças e aos adolescentes o respeito aos seus direitos como pessoas humanas e cidadãos,

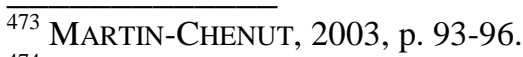

${ }^{474}$ Ibid., loc. cit.

${ }^{475}$ CASTRO, A., 1998, p. 17-18.
} 
e como pessoas na condição peculiar de estar em desenvolvimento; ou seja, em transformação física, psíquica, emocional e espiritual ${ }^{476}$.

O Estatuto da Criança e do Adolescente incorpora, na dimensão jurídica, processos de lutas e reivindicações pela melhoria das condições de vida da infância e da adolescência, já que apresenta, em suas disposições, um forte teor programático das políticas sociais que quer atingir, e não se restringe, como na legislação anterior, à disciplina da vigilância ou da tutela de parte da infância e da adolescência. Ele dispõe, também, sobre deveres da família ${ }^{477}$, do Estado e da sociedade, e põe a criança e o adolescente como titulares de direitos e responsabilidades, havendo necessidade de sua participação nas decisões de seu interesse e do respeito a sua autonomia, garantindo o seu desenvolvimento integral ${ }^{478}$.

Assim, o estatuto passou a dar tratamento aos menores como sujeitos de direitos, garantindo-lhes os direitos inerentes a toda pessoa, mais os seus direitos individuais específicos $^{479}$, e não mais os tratando como meros objetos da intervenção estatal, sendo consideradas crianças as pessoas até 12 anos incompletos e adolescentes, entre 12 e 18 anos de idade.

Quanto ao respeito pela dignidade dos adolescentes, o Estatuto da Criança e do Adolescente deu às medidas socioeducativas uma racionalidade e proporcionalidade que não se via antes, estabelecendo, como finalidades da intervenção estatal, uma prevenção geral, que se dá através da restrição ou limitação de direitos do jovem, e uma prevenção

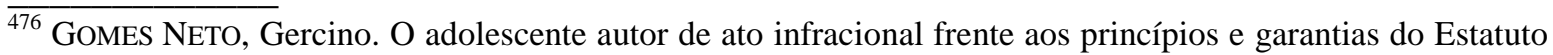
da criança e do adolescente. Revista do ILANUD, São Paulo, n. 14, p. 44-47, 2001. O artigo 6 ${ }^{\circ}$, do Estatuto da Criança e do Adolescente, traz o princípio que reconhece crianças e adolescentes como pessoas em desenvolvimento, superando a desqualificação deles como seres inferiores. As crianças e os adolescentes estão em intenso desenvolvimento de sua personalidade, por isso é peculiar (SPOSATO, 2006-b, p. 104-108).

${ }^{477}$ A respeito das famílias dos jovens infratores, necessário ressaltar que muitos têm a família desestruturada ou sem a mesma organização da família tradicional, o que pode causar a ausência de supervisão parental e dificuldade de assistência aos jovens por parte da família (ALMEIDA, Eloísa Machado de; HoJDA, Alexandre; SPOSATO, Karyna; KAHN, Tulio. Adolescentes suspeitos ou acusados da autoria de atos infracionais em São Paulo - Convênio Ilanud/Febem-SP/PAJ - Infância e Juventude. Revista Brasileira de Ciências Criminais, São Paulo, v. 38, p. 192-194, abr./jun. 2002).

${ }^{478}$ VOLPI, Mario (org.). O adolescente e o ato infracional. $3^{\mathrm{a}}$ ed. São Paulo: Cortez / INESC, 1999. p. 14.

${ }^{479}$ TeIXEIRA, Caroline Köhler. As medidas socioeducativas do estatuto da criança e do adolescente e seus parâmetros normativos de aplicação. Revista da ESMESC: Escola Superior da Magistratura do Estado de Santa Catarina, Florianópolis, v. 20, n. 26, p. 151-153, 2013.
} 
especial, cujo objetivo é diminuir a vulnerabilidade da pessoa frente ao próprio sistema e, também, sua marginalização social ${ }^{480}$.

A racionalidade do estatuto se encontra em seu artigo 112, parágrafo $1^{\circ}$, que, garante o respeito ao princípio da condição peculiar de pessoa em desenvolvimento ao estabelecer que o adolescente deve ter condições de cumprir a medida socioeducativa, além de determinar a individualização da medida. A proporcionalidade está no artigo 122, parágrafo $2^{\circ}$, do estatuto, que reduz a intervenção penal ao mínimo indispensável, tanto em sua duração quanto em sua forma de cumprimento, reconhecendo, desta forma, o interesse superior do jovem como pessoa em desenvolvimento e a dignidade humana como fundamento do Estado de Direito ${ }^{481}$.

Ainda, para o devido respeito à dignidade humana e ao princípio da humanidade, o Direito Penal Juvenil deve incorporar todas as garantias decorrentes do respeito à condição peculiar de pessoa em desenvolvimento, como a prevista no artigo 227, caput, da Constituição Federal, que condiciona a privação de liberdade do adolescente aos princípios da brevidade e excepcionalidade, tendo em vista que a liberdade é um direito que deve ser assegurado com absoluta prioridade ${ }^{482}$.

O modelo de responsabilidade penal da criança e do adolescente trazido pela Lei Federal n $n^{\circ} 8.069 / 1990$ permite a superação do caráter tutelar e do caráter repressivo das legislações passadas, pois apresenta um modelo de justiça e de garantias ${ }^{483}$. O binômio ato infracional - medida socioeducativa é adotado em detrimento à ideia de ato antissocial.

Este novo Direito Penal Juvenil está vinculado aos mesmos objetivos e missão do direito penal moderno, possuindo um variado número de princípios e regras que funcionam como limite e garantia em face do poder punitivo estatal, impedindo medidas abusivas, orientando uma reação ao delito juvenil que promova a integração social e a observância dos direitos da criança e do adolescente, como a proteção deles diante do arbítrio

\footnotetext{
$\overline{480}$ SPOSATO, 2006-b, p. 97-101.

${ }^{481}$ SPOSATO, 2006-b, loc. cit.

${ }^{482}$ SHECAIRA, 2008, p. 146.

${ }^{483}$ GARCÍA MÉNDEZ, 2004, p. 232-236.
} 
público $^{484}$ e a imposição de sanções que devem ser aplicadas dentro do devido processo legal, sob os princípios penais e a ordem constitucional, que asseguram os direitos da cidadania $^{485}$.

Assim, o Estatuto da Criança e do Adolescente controlou arbitrariedades legislativas, racionalizando a repressividade, que deve estar norteada pela preservação da personalidade do menor, com medidas próprias e adequadas às características dele, e não medidas importadas da legislação de adultos, vedando, assim, injustas, desproporcionais e pouco efetivas repressões de duvidosa conotação democrática ${ }^{486}$.

\subsubsection{A inimputabilidade penal}

Conforme o artigo 228, da Constituição Federal, são penalmente inimputáveis os menores de 18 anos, sujeitos às normas de legislação especial, disposição que se repete no artigo 27, do Código Penal. A legislação especial a que se referem os artigos citados é o Estatuto da Criança e do Adolescente, que também repete essa disposição em seu artigo 104.

Não há uma definição de imputabilidade, e sim a sua negativa; ou seja, a inimputabilidade, que, como citado acima, baseia-se no aspecto biológico da pessoa, prescindindo de qualquer indagação psicológica acerca dos menores de $18 \operatorname{anos}^{487}$. Assim, a legislação penal não leva em consideração o desenvolvimento mental do menor, mesmo que este seja capaz de entender o caráter ilícito de seu ato e de autodeterminar-se conforme este entendimento.

A inimputabilidade aos 18 anos é uma opção de política criminal consistente, que oferece um tratamento diferenciado para a juventude delinquente. Criam-se medidas e programas específicos de responsabilização, que não se confundem com a

\footnotetext{
$\overline{{ }^{484} \text { SPOSATO, 2006-b, p. 63-70. }}$

485 SARAIVA, 2009, p. 100-106.

486 SAAD-DINIZ, Eduardo. A proteção penal do menor: entre a medida socioeducativa e a repressão ao inimigo. Revista Magister de Direito Penal e Processual Penal, Porto Alegre, v. 8, n. 45, p. 80-81, dez./jan. 2012.

${ }^{487}$ SPOSATO, op. cit, p. 70-82.
} 
descriminalização de condutas. O que ocorre é a sua penalização de forma distinta, por meio de medidas socioeducativas ${ }^{488}$.

Essa responsabilidade especial decore do reconhecimento da dignidade humana dos menores, mais precisamente do reconhecimento de uma situação peculiar de desenvolvimento que demanda sanções específicas próprias; não deixando de se verificar, a despeito da inimputabilidade, a reprovabilidade e a culpabilidade do adolescente a quem a medida é imposta. Contudo deve-se garantir que essa via de responsabilização não seja mais severa e aguda do que a via tradicional que se pretende evitar ${ }^{489}$.

O adolescente é pessoa em desenvolvimento, possuindo características peculiares, e como tal deve ser tratado por todos, inclusive por aqueles que fazem parte do sistema penal $^{490}$.

O modelo jurídico de responsabilidade inaugurado no Estatuto da Criança e do Adolescente nos permite afirmar que a inimputabilidade não exclui a reprovabilidade e, portanto, não é sinônimo de irresponsabilidade ou impunidade para os adolescentes autores de infrações penais, pois não isenta a pessoa menor de 18 anos de responsabilização e sancionamento, apenas não a submete ao Código Penal, e sim a um sistema especial direcionado aos adolescentes, tendo sem vista a sua condição peculiar de pessoa em desenvolvimento ${ }^{491}$.

A responsabilidade penal do adolescente é um componente central a seu direito de plena cidadania, pois não há cidadania sem responsabilidade ${ }^{492}$.

\footnotetext{
${ }^{488}$ SPOSATO, 2006-b, p. 63-70. Para os jovens, o Código Penal traz, ainda, a atenuante genérica de ser menor de 21 anos, no artigo 65, inciso I, do Código Penal, e a prescrição reduzida pela metade, conforme artigo 115, do mesmo código.

${ }^{489}$ Ibid., p. 70-82.

${ }^{490}$ GOMES Neto, 2001, p. 43.

${ }^{491}$ SARAIVA, 2009, p. 120-126.

${ }^{492}$ GARCÍA MÉNDEZ, 2004, p. 236-241.
} 
4.2.1.1. Das discussões acerca da redução da inimputabilidade penal

Hoje, muito se tem discutido acerca da redução da inimputabilidade penal, em razão da sensação de insegurança e impunidade que as pessoas têm em relação aos atos infracionais cometidos por adolescentes.

Isso ocorre tendo em vista alguns mitos que se formaram ao redor do problema da delinquência juvenil, como o causado pelo hiperdimensionamento do problema em que se cria a sensação de insegurança na população e impressão de que se trata de uma questão de dimensões intangíveis e impossível de resolver ${ }^{493}$.

Contudo, na realidade, a participação de jovens nos crimes violentos não é tão significativa comparativamente aos crimes praticados por adultos, e é por ser uma exceção que causa alarme na população quando praticados ${ }^{494}$. Em pesquisa realizada numa Unidade de Atendimento Inicial, constatou-se que $45,8 \%$ dos jovens eram acusados de crimes contra o patrimônio, e apenas 1,4\% eram acusados de homicídio. Ainda, esses números se referem às condutas imputadas aos jovens, e não às já sentenciadas ${ }^{495}$.

Geralmente, as pesquisas sobre a criminalidade juvenil se constroem sobre a população de jovens internados, e não sobre todos os que cumprem medidas socioeducativas ou que entram no sistema infracional juvenil. Isso constrói uma imagem distorcida do infrator, mais violento e perigoso do que é na realidade, contribuindo para o endurecimento das ações e políticas públicas de atenção à delinquência juvenil ${ }^{496}$.

Ademais, os meios de comunicação disseminam a ideia de impunidade, levando as pessoas a interpretar a inimputabilidade como se o adolescente fosse irresponsável, podendo cometer qualquer delito sem que nada lhes aconteça, o que não é verdade, pois o

\footnotetext{
$\overline{493}$ VOLPI, 2001, p. $23-28$.

494 Sposato, Karyna Batista. Só se educando. Revista do ILANUD, São Paulo, n. 12, p. 13-16, 1998, SPosATo, Karyna Batista. O jovem: conflitos com a lei; a lei : conflitos com a prática. Revista Brasileira de Ciências Criminais, São Paulo, v. 8, n. 30, p. 109-112, abr./jun. 2000.

${ }^{495}$ ALMEIDA, E.; et al., 2002, p. 172-179.

496 Ibid., p. 167-179.
} 
jovem é julgado por seu ato infracional e terá designada sua pena por critérios de uma legislação especial, o Estatuto da Criança e do Adolescente ${ }^{497}$.

Essa sensação maquia uma questão que deveria ser resolvida pelo próprio Estado, por exemplo, com a aplicação de maiores investimentos na prevenção da criminalidade, com a maior fiscalização do emprego de armas de fogo e armas brancas por crianças, jovens e adultos ${ }^{498}$.

O Estado não assegura, também, condições mínimas de existência digna, provocando traumatismo na estrutura social que abalará suas bases mais frágeis. Os jovens em conflito com a lei, apesar de os direitos a eles assegurados, vivem em comunidades periféricas e marginais, desprovidos dos recursos materiais necessários a uma vida digna, bem como se encontram carentes de educação, saúde e lazer ${ }^{499}$.

Eles são tentados, a, por exemplo, ingressar no tráfico de drogas, em troca de prestígio social, de vantagens econômicas, e na medida em que os meios lícitos não os conduziriam ao mesmo sucesso ${ }^{500}$. Assim, antes de políticas encarceradoras desses adolescentes, é necessário o investimento em políticas sociais, para impedir que eles ingressem na criminalidade.

Além disso, apesar de muitos afirmarem que o adolescente já sabe o que faz, a inimputabilidade é diferente da imaturidade. Eles podem ter consciência do ato praticado, mas para o menor infrator, é mais eficaz a sua submissão à medida socioeducativa do que a cadeia junto do delinquente adulto, onde se aperfeiçoaria na prática do crime, pois o sistema prisional causaria um contato pernicioso com criminosos adultos. Além disso, a

\footnotetext{
$\overline{497}$ VOLPI, 2001, p. $28-30$.

${ }^{498}$ CASTRO, A., 1998, p. 19-22.

499 PRADO, Geraldo. Violência infanto-juvenil e os processos de vitimização. In: KosovSKI, Ester; SÉGUIN, Elida (Coords). Temas de vitimologia. Rio de Janeiro: Lumen Juris, 2000. p.124-129.

${ }^{500}$ PRADO, G., 2000, loc. cit.
} 
realidade prisional é extremamente degradada, com superlotação, contaminação à corrupção e perda paulatina da aptidão para o trabalho ${ }^{501}$.

Colocar os jovens no mesmo sistema carcerário que os adultos causaria um recrudescimento da violência à medida que esses adolescentes fossem soltos, pois um criminoso patrimonial se misturaria com criminoso contra a vida, funcionando a prisão como um mecanismo de propulsão da criminalidade e da violência ${ }^{502}$.

Necessário ressaltar que, se a mera aplicação das normas penais diminuísse a criminalidade, já teria havido uma grande redução do número de crimes praticados por adultos, o que está longe de acontecer ${ }^{503}$.

Deve-se apresentar aos adolescentes direções necessárias à busca de uma convivência social que se pretende pacífica e harmônica, garantindo-lhe todos os direitos que lhe são inerentes, como educação formal, profissionalização, saúde, lazer ${ }^{504}$.

Dos jovens que cumprem medidas socioeducativas, $91 \%$ não têm o ensino fundamental completo, o que mostra que eles estão em um contexto carente de política públicas, inclusive excluídos da escola ${ }^{505}$.

Assim, o reajustamento do processo de formação do caráter deve ser cometido à educação, não à pena criminal, e sem expor o adolescente ao tratamento do adulto infrator e à contaminação carcerária ${ }^{506}$. Ademais, o sistema de justiça penal juvenil está mais bem aparelhado, jurídica e institucionalmente, do que o sistema penal dos adultos ${ }^{507}$.

\footnotetext{
${ }_{501}$ FIRMO, Maria de Fátima Carrada. A criança e o adolescente no ordenamento jurídico brasileiro. Rio de Janeiro: Renovar, 1999. p. 83-98.

502 JUNQUEIRA, Ivan de Carvalho. Do ato infracional à luz dos direitos humanos. Campinas: Russell, 2009. p. $70-76$.

${ }^{503}$ CASTRO, A., 1998, p. 19-22.

504 JUNQUEIRA, op. cit., p. 97-98.

${ }^{505}$ SPOSATO, 1998, p. 13-16.

${ }^{506}$ FIRMO, op. cit., p. 83-90.

${ }^{507}$ ViAnNA, Guaraci de Campos. Responsabilidade penal dos adolescentes e medidas socioeducativas. Revista da EMERJ, Rio de Janeiro, v. 10, n. 40, p. 212-214, 2007.
} 
Além disso, a imputabilidade aos 18 anos é um direito e garantia fundamental do adolescente, portanto, cláusula pétrea ${ }^{508}$. O rebaixamento da maioridade penal, além de inconstitucional, seria inútil, pois não há grandes diferenças entre internação de um adolescente e prisão de um adulto, sendo que a medida socioeducativa de internação é hoje a referência de todo o sistema ${ }^{509}$.

Os adolescentes devem continuar sendo inimputáveis, ou seja, não devem ser submetidos ao mesmo processo e sanções dos adultos, mas devem continuar sendo penalmente responsáveis por seus atos, pois essa responsabilidade constitui um avanço sobre a legislação com caráter tutelar, que imputava ao adolescente responsabilidade por atos antissociais e que legitimava o subjetivismo dos operadores da lei ${ }^{510}$.

4.2.2. Os direitos e garantias da criança e do adolescente em conflito com a lei

Com a adoção do Estatuto da Criança e do Adolescente e dos demais instrumentos citados anteriormente, que trataram dos direitos do menor, as crianças e os adolescentes passaram a gozar de direitos consagrados para todos os seres humanos, cujo dever de promoção e garantia é do Estado. Ainda, conforme enuncia o artigo 41, da Convenção sobre os Direitos da Criança, os mecanismos de proteção dos menores, como os direitos específicos a eles, são sempre complementares, nunca substitutivos dos mecanismos gerais de proteção dos direitos reconhecidos a todas as pessoas ${ }^{511}$.

Os adolescentes em conflito com a lei são detentores, portanto, dos direitos que têm os adultos, mais os direitos decorrentes de sua situação de peculiar desenvolvimento; por isso, todas as garantias do direito penal do adulto devem ser asseguradas ao adolescente, de forma a impedir qualquer prejuízo ao seu desenvolvimento e formação ${ }^{512}$. Estes direitos devem ser garantidos ao adolescente, pois, mesmo que privados de liberdade, não perdem

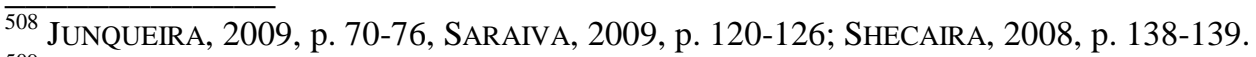

509 VIDAL, Luis Fernando Camargo de Barros. Medidas sócio-educativas. Revista Brasileira de Ciências Criminais, São Paulo, v. 10, n. 37, p. 199-203, jan./mar. 2002.

${ }^{510}$ GARCÍA MÉNDEZ, 2004, p. 232-241.

${ }^{511}$ SPOSATO, 2006-b, p. 63-70.

512 SPOSATO, 2006-a, p. 139-143.
} 
sua personalidade humana, sendo tal prerrogativa indissociável, pois característica inerente da pessoa $^{513}$.

Como já visto, é assegurada aos menores de 18 anos a inimputabilidade penal, conforme artigo 228, da Constituição Federal, sendo sua responsabilidade apurada na forma da legislação especial.

Mas, a Constituição Federal também garante outros direitos específicos ao adolescente. A liberdade, por estar o adolescente em condição peculiar de desenvolvimento, deve estar condicionada aos princípios da brevidade e da excepcionalidade, conforme artigo 227 , parágrafo $3^{\circ}$, inciso $\mathrm{V}$, do texto constitucional. Este artigo da Constituição traz, ainda, outros direitos ao menor, como os previstos no parágrafo $3^{\circ}$, inciso IV, que prevê a igualdade na relação processual, defesa técnica por profissional habilitado e garantia de citação do adolescente, com todas as circunstâncias do ato infringido, sob pena de nulidade ${ }^{514}$, garantias também previstas no artigo 111 , do Estatuto da Criança e do Adolescente.

O direito à defesa técnica é assegurando independentemente da natureza e gravidade do ato infracional imputado ao adolescente, sendo necessária a presença de advogado inclusive na oitiva informal feita pelo Ministério Público ${ }^{515}$, pois é um momento importante, onde serão tomadas decisões que repercutirão até o final do processo. Um advogado preserva os direitos do adolescente na remissão, bem como na determinação da internação provisória ${ }^{516}$.

No Estatuto da Criança e do Adolescente, os artigos 106 a 111 preveem os direitos relativos ao devido processo legal em face da prática de um ato infracional, que são os mesmos direitos e garantias inerentes do adulto processado criminalmente ${ }^{517}$. Aos menores

\footnotetext{
$\overline{513}$ JUNQUEIRA, 2009, p. 80-82.

${ }^{514}$ Elias, Roberto Joao. Comentários ao Estatuto da Criança e do Adolescente (Lei n. 8.069, de 13 de julho de 1990). $3^{\text {a }}$ ed. São Paulo: Saraiva, 2008. p. 117-120.

515 SHECAIRA, 2008, p. 180-181.

516 ANDRADE, Anderson Pereira de. Aplicação de medidas socioeducativas privativas de liberdade e direitos fundamentais. Boletim Científico - Escola Superior do Ministério Público da União, Brasília, ano 1, n. 5, p. 13-15, out./dez., 2002.

${ }^{517}$ GOMES NETO, 2001, p. 47-49.
} 
infratores também devem ser observados os princípios da legalidade, presunção de inocência, do devido processo legal, entre outros, conforme artigo 152, do estatuto, pois não se justifica uma graduação na aplicação dessas garantias, sob uma pretensa proteção do adolescente, pois há possibilidade de intervenção do Estado na liberdade dele ${ }^{518}$.

O artigo 106, do estatuto, prevê que o adolescente só pode ser privado de sua liberdade em caso de flagrante de ato infracional ou por ordem escrita e fundamentada da autoridade judiciária competente, ou seja, deve se basear na presença de provas da materialidade e indícios suficientes de autoria. Ainda, este dispositivo deve ser interpretado de forma restrita, pois a criança jamais será privada de sua liberdade ${ }^{519}$.

Nos artigos 110 e 111, do Estatuto da Criança e do Adolescente, estabelecem-se as garantias processuais dos adolescentes. Além das garantias previstas no artigo 227, da Constituição Federal, também constam o direito de não ser privado de liberdade sem o devido processo legal, o direito de assistência judiciária gratuita e integral aos necessitados, o direito de ser ouvido pessoalmente pela autoridade competente e o direito de solicitar a presença de seus pais ou responsável em qualquer fase do procedimento, para prestar esclarecimentos e dar assistência moral ao jovem ${ }^{520}$.

Também se aplicam aos adolescentes outros direitos e garantias processuais, como, apenas exemplificativamente, os previstos nos incisos XXXVII, XLIX, LV, LVII e LXV, do $\operatorname{artigo} 5^{\circ}$, da Constituição Federal ${ }^{521}$.

Assim, o Estatuto da Criança e do Adolescente constitui uma resposta adequada, eficiente e concordante com o respeito aos direitos humanos, assegurando a segurança da sociedade e o respeito rigoroso das garantias individuais dos adolescentes ${ }^{522}$. No entanto, a

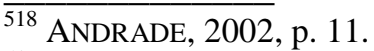

${ }^{519}$ ELIAS, 2008, p. 113-117.

${ }^{520}$ Ibid., p. 117-120.

${ }^{521}$ SPOSATO, 2006-b, p. 82-86.

${ }^{522}$ GARCÍA MÉNDEZ, 2004, p. 243-245.
} 
responsabilidade juvenil só causará impacto pedagógico-social se os direitos dos adolescentes forem assegurados ${ }^{523}$.

\subsubsection{O ato infracional}

Conforme enuncia o artigo 103, do Estatuto da Criança e do Adolescente, ato infracional é a conduta descrita como crime ou contravenção penal.

Para se avaliar se a conduta pratica pelo menor constitui-se um ato infracional, é necessário constatar se o ato é uma ação típica e antijurídica, avaliando as excludentes de tipicidade e antijuridicidade, dos artigos 20 a 22, do Código Penal, bem como os demais elementos da culpabilidade, como a potencial consciência da ilicitude e a inexigibilidade de conduta diversa, pois é inadmissível a responsabilidade penal objetiva ${ }^{524}$. O sistema de responsabilização presente no Estatuto da Criança e do Adolescente não prescinde, ademais, das condições subjetivas: dolo e culpa ${ }^{525}$.

Como previsto no artigo 105, do Estatuto da Criança e do Adolescente, até os 12 anos, não há responsabilidade juvenil, estando a criança sujeita às medidas protetivas previstas no artigo 101, do mesmo estatuto. A partir dos 12 anos, até os 18, é imputada responsabilidade ao adolescente, estando ele sujeito à medida socioeducativa ${ }^{526}$.

Desta forma, o Direito Penal Juvenil prevê dois tipos de intervenção: a medida de proteção, de competência dos Conselhos Tutelares, exceto as previstas no artigo 101, incisos VIII e IX, do estatuto, sujeitas à revisão pelo Poder Judiciário ${ }^{527}$, e a medida

\footnotetext{
$\overline{523}$ ZAPATA, Fabiana Botelho. Internação: medida socioeducativa? Reflexões sobre a socioeducação associada à privação de liberdade. Revista da Defensoria Pública, São Paulo, Ed. especial temática sobre infância e juventude, n. 3, p. 44-45, 2008.

${ }^{524}$ SARAIVA, 2009, p. 100-106. Conforme o enunciado 338, da Súmula do Superior Tribunal de Justiça, a prescrição alcança as medidas socioeducativas e é calculada pelos prazos previstos no artigo 109, do Código Penal, reduzidos à metade em razão de os adolescentes terem menos de 21 anos, a teor do artigo 115, desse mesmo código (SHECAIRA, 2008, p. 191).

${ }^{525}$ SHECAIRA, op. cit., p. 169.

${ }^{526}$ SPOSATO, 2006-b, p. 104-108; VOLPI, 1999, p. 15-16. Conforme o artigo 104, parágrafo único, do Estatuto da Criança e do Adolescente, deve ser considerada a idade do menor à data do fato para averiguar se é cabível a imposição de uma medida socioeducativa.

${ }^{527}$ SHECAIRA, op. cit., p. 171-172. Para FIRMO, isso retira do Judiciário competência assegurada pelo artigo $5^{\circ}$, inciso XXXV, da Constituição Federal. Sob o pretexto de se proteger a criança das formalidades que envolve
} 
socioeducativa, de competência do Poder Judiciário, sendo essa diferenciação entre criança e adolescente necessária, pois as crianças, que são penalmente inimputáveis e irresponsáveis, não têm as mesmas condições biopsicossocioculturais que os adolescentes, penalmente responsáveis, bastando a ela as medidas de proteção ${ }^{528}$.

Após a prática do ato infracional, estão sujeitos, os menores, às medidas protetivas, às medidas socioeducativas, ou, ainda, à remissão, como se verá a seguir.

\subsubsection{As medidas protetivas}

Previstas nos artigos 98 a 102, do Estatuto da Criança e do Adolescente, as medidas protetivas são aplicáveis sempre que os direitos reconhecidos pelo estatuto estiverem ameaçados ou violados por ação ou omissão da sociedade ou do Estado, por falta, omissão ou abuso dos pais ou responsável, ou em razão da conduta do menor.

Assim, não é necessário que a criança ou o adolescente pratique ato infracional para que se aplique uma medida de proteção, basta que ocorra uma das hipóteses do artigo 98, da Lei Federal $n^{\circ}$ 8.069/1990; mas, se a aplicação for em decorrência da prática de ato infracional, deve a medida de proteção permitir a readequação comportamental deles ${ }^{529}$.

O artigo 101, da Lei $\mathrm{n}^{\circ}$ 8.069/1990, traz um rol exemplificativo de medidas protetivas, onde constam, por exemplo, o encaminhamento aos pais ou responsáveis, mediante termo de responsabilidade, matrícula e frequência obrigatórias em estabelecimento oficial de ensino fundamental e requisição de tratamento médico, psicológico ou psiquiátrico, em regime hospitalar ou ambulatorial.

o Poder Judiciário, o Conselho Tutelar exerce, assim, função tipicamente judiciária, convertendo-se num órgão com atribuição sui generis, no nosso sistema administrativo, retirando da competência do Poder Judiciário a apreciação dos atos infracionais praticados por crianças (FIRMO, 1999, p. 98-102).

${ }^{528}$ FIRMO, op. cit., p. 102-107.

${ }^{529}$ VIANNA, 2007, p. 226-228. 
Essas medidas têm natureza administrativa ${ }^{530}$ e conteúdo fortemente pedagógico, tendo em vista que têm por objetivo o fortalecimento dos vínculos familiares e comunitários, conforme artigo 100, do estatuto. Por isso, devem ser aplicadas sem caráter sancionatório, e não decorrerá de ato em si praticado pela criança ou pelo adolescente, mas sim de circunstância pessoal que a reclame ${ }^{531}$.

Assim, são despidas de qualquer viés disciplinar no sentido empregado na medida socioeducativa, e se constituem instrumento de proteção integral da criança e do adolescente, que germinam e desenvolvem as capacidades deles como sujeitos de $\operatorname{direitos}^{532}$.

\subsubsection{A remissão}

Considerando que o procedimento judicial para apuração de ato infracional é, em si, negativo e deve ser evitado ${ }^{533}$, antes de seu início, poderá ser concedida ao adolescente, pelo membro do Ministério Público, a remissão, que é forma de exclusão do processo, atendendo às circunstâncias e consequências do fato, ao contexto social, bem como à personalidade do adolescente e sua maior ou menor participação no ato infracional, conforme artigo 126, do Estatuto da Criança e do Adolescente. Ainda, de acordo com o parágrafo único deste artigo, caso seja iniciado o procedimento, a concessão da remissão poderá ser feita pelo magistrado, que importará na suspensão ou extinção do processo, desde que ouça o órgão ministerial a respeito da concessão, sob pena de nulidade, conforme artigo 204 , do estatuto ${ }^{534}$.

Conforme disposto no artigo 127, do estatuto, a remissão não implica necessariamente na comprovação ou reconhecimento da responsabilidade, e não pode, portanto, ser levada em conta como antecedente, como na previsão do artigo 122, inciso II,

\footnotetext{
${ }^{530}$ SHECAIRA, 2008 , p. 171-172.

${ }^{531}$ SARAIVA, 2009, p. 100-106.

${ }^{532}$ VIDAL, 2002, p. 206-208.

${ }^{533}$ Ibid., p. 193-196.

${ }^{534}$ ELIAS, 2008, p. 140-144. A remissão concedida pelo membro do Ministério Público deve ser homologada pela autoridade judiciária. Caso esta não concorde com a remissão, deve enviar o processo para o Procuradorgeral, que, caso ratifique a remissão, esta deve ser obrigatoriamente homologada pelo magistrado (FIRMO, 1999, p. 102-107).
} 
do estatuto, que estabelece as hipóteses de aplicação da medida socioeducativa de internação $^{535}$. Ademais, esta exclusão do processo pode ser cumulativamente aplicada com medidas socioeducativas, exceto a colocação em regime de semiliberdade e internação, pois estas exigem, para sua aplicação, prova plena da materialidade e autoria delitivas ${ }^{536}$.

Esta vedação se estende também à substituição de uma medida não privativa de liberdade aplicada na remissão por uma dessas duas que interferem na liberdade do adolescente.

Em relação à aplicação de medidas socioeducativas em sede de remissão, o enunciado 108, da Súmula do Superior Tribunal de Justiça estabeleceu que a aplicação dessas medidas é de competência exclusiva do juiz, ou seja, não podem ser aplicadas pelos membros do Ministério Público. Assim, pode o Ministério Público aplicar a remissão, mas não cumulá-la com outra medida, ou representar ao juiz, para que aplique as medidas socioeducativas, conforme artigo 180 , inciso III, do estatuto ${ }^{537}$.

A aplicação de medidas socioeducativas pelo promotor, sem o respaldo judicial, pode dar maior margem de arbitrariedade a ele, pois, aplicada em sede de remissão, evita o devido processo legal, podendo punir o adolescente conforme critérios de culpabilidade do autor, sua personalidade, seus hábitos, sua posição social, família, podendo, desta forma, velhos conceitos repudiados retornarem à cena ${ }^{538}$.

Por fim, de acordo com o artigo 128, do Estatuto da Criança e do Adolescente, as medidas socioeducativas aplicadas na remissão podem ser revista a qualquer tempo, sem que seja necessário um recurso judicial.

\footnotetext{
$\overline{535}$ ELIAS, 2008, p. 140-144.

536 TEIXEIRA, 2013, p. 168-170.

${ }^{537}$ ELIAS, op. cit., p. 140-144.

538 VIDAL, 2002, p. 193-196; SILVA, Roberto Baptista Dias da. Abolicionismo penal e os adolescentes no Brasil. In: SiLva, Roberto Baptista Dias da; PASSETTI, Edson (Org.). Conversações abolicionistas. São Paulo: IBCCRIM / PEPG de Ciências Sociais da PUC-SP, 1997. p. 131-133.
} 


\subsubsection{As medidas socioeducativas}

Previstas a partir do artigo 112, do Estatuto da Criança e do Adolescente, que traz um rol taxativo, as medidas socioeducativas podem ser aplicadas apenas ao adolescente caso seja verificada a prática do ato infracional. Essas medidas serão aplicadas a critério do juiz, sendo que não há obrigatoriedade em aplicá-las ${ }^{539}$.

Não aplicar uma medida socioeducativa, apesar do reconhecimento da prática do ato infracional, é o marco divisor entre disciplina e promoção de direitos, e o elemento limitador dessa possibilidade é a consideração da gravidade do ato infracional e a condição peculiar do adolescente também no processo de cognição do ato infracional ${ }^{540}$.

As medidas socioeducativas são espécies do gênero sanção penal, tendo, portanto, natureza penal $^{541}$ e viés retributivo, mas finalidade pedagógica, com uma proposta socioeducativa $^{542}$.

A lei evita o uso do termo "pena" para designar as consequências jurídicas previstas para os menores infratores, mas são verdadeiras sanções e castigos ${ }^{543}$.

Apesar de o enfoque do Estatuto da Criança e do Adolescente ser educativopedagógico, e não repressivo-punitivo, não é possível negar o conteúdo aflitivo das medidas socioeducativas, pois é a resposta possível pelo descumprimento da norma comportamental imposta pela ordem jurídica ${ }^{544}$, e implica, necessariamente, uma limitação ou restrição de direitos ou de liberdade. Elas consideram, ainda, o delito cometido, fundamentam-se na responsabilidade da pessoa, procuram evitar a prática de novos atos infracionais por adolescentes, além de, quando da prática de um ato infracional, remetem-

\footnotetext{
539 ELIAS, 2008, p. 120-124.

${ }^{540}$ VIDAL, 2002, p. 203-208.

${ }^{541}$ Em sentido contrário, CostA, Cláudio Hortêncio. Medidas sócio-educativas e a conjuntura. Revista do ILANUD, São Paulo, n. 14, p. 37-38, 2001; GOMES NETO, 2001, p. 49-53.

542 SPOSATO, 2006-b, p. 114-118; JUNQUEIRA, 2009, p. 103-104; VIANNA, 2007, p. 214-218 e 225; SARAIVA, 2009, p. 100-106.

${ }^{543}$ ABEL SOUTO, Miguel. Las medidas del nuevo derecho penal juvenil: consideraciones en torno al artículo 7 de la ley penal del menor. Actualidad Penal, Madrid, v. 1, n. 6, p. 106-107, fev. 2002.

${ }^{544}$ SPOSATO, 2000, p. 109-112.
} 
se ao Código Penal para verificar o tipo penal, desconsiderando-se apenas o termo secundário $^{545}$.

No entanto, o reconhecimento do caráter penal e sancionatório da medida socioeducativa não retira a tarefa e o desafio pedagógico que se colocam para a justiça e para os programas de atendimento socioeducativos ${ }^{546}$.

O que não se pode admitir é que o discurso pedagógico oculte um sistema altamente repressivo no tratamento do adolescente infrator, haja vista ser a medida socioeducativa uma reação punitiva estatal ${ }^{547}$. Desta forma, é necessário respeitar as garantias constitucionais do adolescente, sendo que os escopos pedagógicos da medida socioeducativa devem se sobrepor aos meramente expiatórios ${ }^{548}$.

A imposição das medidas socioeducativas, além de restrita e limitada aos casos de estrita necessidade, deve estar adstrita à obtenção de suas finalidades preventivas, com destaque para a prevenção especial, que deve ser a de diminuir a vulnerabilidade do criminalizado ao próprio sistema penal, por meio da oferta de um conjunto de serviços e políticas sociais ${ }^{549}$. Deve pretender, também, a consolidação da cidadania dos adolescentes e o descolamento entre o sujeito e o ato praticado, sendo oportunidade de revisão, pelos adolescentes, de suas próprias vidas e da funcionalidade de suas dinâmicas pessoais para sua própria realização e para a experiência de viver bem em sociedade ${ }^{550}$.

Devem, portanto, as medidas socioeducativas ser aplicadas com o objetivo de retorno do jovem à família e à sociedade e de diminuir as chances de reincidência, visando o adolescente e os possíveis caminhos que possam reconduzi-los à plena fruição de seus direitos, respeitando sua condição de pessoa em estágio peculiar de desenvolvimento ${ }^{551}$.

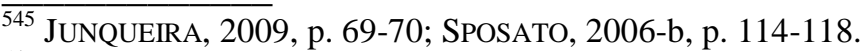

${ }^{546}$ SPOSATO, 2006-a, p. 139-143.

${ }^{547}$ ZAPATA, 2008, p. 44-45.

${ }^{548}$ TEIXEIRA, 2013, p. 159-168.

${ }^{549}$ SPOSATO, 2006-b, p. 63-70, 114-118.

${ }^{550}$ SANTOS, D., 2012, p. 52-58.

551 TEIXEIRA, op. cit., p. 182-184.
} 
Para se aplicar uma medida socioeducativa a um adolescente, é necessário que haja provas suficientes da autoria e da materialidade da infração, ressalvadas as hipóteses de remissão e advertência, conforme previsão do artigo 114, do Estatuto da Criança e do Adolescente.

Ainda, como referido acima, é necessário respeitar as garantias processuais, como, por exemplo, a que determina que as decisões devam ser motivadas, conforme o artigo 381, do Código de Processo Penal, e as disposições trazidas no artigo 100, do Estatuto da Criança e do Adolescente, como a adoção de medidas que fortaleçam os vínculos familiares do adolescente, bem como os sociais.

Caso não seja hipótese de absolvição, diante do rol dos artigos 152 e 189, do Estatuto da Criança e do Adolescente, e do artigo 386, inciso VI, do Código de Processo Penal, e, havendo condenação, a medida socioeducativa deve ser individualizada, conforme as circunstâncias do artigo 112, parágrafo $1^{\circ}$, do estatuto, que considera a capacidade do jovem de cumprir a medida, a gravidade da infração e as circunstâncias, que se assemelham às do artigo 59, do Código Penal ${ }^{552}$. Essas circunstâncias são as dimensões da pessoa, como a saúde física, emocional, situação econômica e cultural, conflitos inerentes à condição de pessoa em desenvolvimento, aspectos estruturais de personalidade $^{553}$.

É importante se atentar para a capacidade do jovem em cumprir a medida socioeducativa, pois a incapacidade do adolescente em cumpri-la pode gerar um juízo negativo de incapacidade ou inaptidão para as coisas da vida, provocando rebaixamento de autoestima e prejuízos à formação da personalidade do adolescente ${ }^{554}$.

Ademais, a medida socioeducativa deve ser fixada de maneira proporcional e dentro dos limites estabelecidos pela Constituição Federal e pelas leis, pois não pode

\footnotetext{
552 SARAIVA, João Batista Costa. Compêndio de direito penal juvenil: adolescente e ato infracional. $3^{\mathrm{a}}$ ed. Porto Alegre: Livraria do Advogado, 2006. p. 178.

${ }^{553}$ VOLPI, 1999, p. 15-16; GOMES NETO, 2001, p. 49-53.

554 TEIXEIRA, 2013, p. 188-195.
} 
significar marca indelével na vida do adolescente, o qual possui o direito de se redimir do erro cometido e, dessa maneira, construir para si uma vida digna ${ }^{555}$.

As medidas protetivas previstas no artigo 101, incisos I a VI, do Estatuto da Criança e do Adolescente, podem ser cumuladas às socioeducativas, desde que se harmonizem, conforme dispõem os artigos 101, 112, inciso VII, e 136, inciso VI, todos desse estatuto, quando da comprovação de autoria de ato infracional concomitante à situação de risco social e pessoal ${ }^{556}$.

As medidas impostas podem ser substituídas a qualquer tempo, conforme artigos 99 c/c 113, do Estatuto da Criança e do Adolescente, de modo a melhor atender às necessidades do adolescente.

Conforme o artigo 112, parágrafos $1^{\circ}$ e $3^{\circ}$, do Estatuto da Criança e do Adolescente, o adolescente que padece de sofrimento psíquico que o incapacite não será submetido à medida socioeducativa, não tendo responsabilidade juvenil. Pode, então, ser submetido a uma medida protetiva, como a do inciso V, do artigo 101, desta lei, pois o artigo 112, parágrafo $3^{\circ}$, do estatuto, assegura o direito de receber atendimento individual $\mathrm{e}$ especializado, em local adequado às suas condições, sendo a responsabilidade desses locais dos setores de saúde, tendo em vista que é necessário um espaço especializado de atendimento, pois a unidade de internação não é local adequado para manter esse jovem, mesmo que a doença mental seja superveniente à internação 557 .

Além das disposições previstas no Estatuto da Criança e do Adolescente, foi editada a Lei Federal n ${ }^{\circ}$ 12.594/2012, que instituiu o Sistema Nacional de Atendimento Socioeducativo e regulamentou a execução das medidas socioeducativas, para diminuir a discricionariedade, arbítrio e subjetivismo na execução dessas medidas ${ }^{558}$, tendo em vista que eram necessárias regras claras relativas a essa execução, já que a Justiça da Infância e

\footnotetext{
555 CAStro, Vivian Monsef de. O adolescente infrator e os direitos humanos. Revista da Defensoria Pública, São Paulo, Ed. especial temática sobre infância e juventude, n. 3, p. 137-140, 2008.

${ }^{556}$ SPOSATO, 2006-b, p. 104-108.

${ }^{557}$ SARAIVA, 2006, p. 194-197.

${ }^{558}$ SARAIVA, 2009, p. 120-126.
} 
Juventude é mais informal, negociativa, rápida e, portanto, mais suscetível a interferências subjetivas $^{559}$.

Esta lei quis suprir pretensas lacunas no Estatuto da Criança e do Adolescente, acerca das especificidades das medidas socioeducativas, para impedir que os excessos ou desvios de sua finalidade afetem a dignidade e a humanidade do infrator ${ }^{560}$.

A partir do artigo 35, desta lei, tem-se a execução da medida socioeducativa, destacando-se o inciso I, que determina que um adolescente não pode receber um tratamento mais gravoso do que o conferido a um adulto, a partir do artigo 49, os direitos individuais do adolescente, e no artigo 52, o Plano Individual de Atendimento.

Este Plano Individual de Atendimento deve ser elaborado no início de cumprimento de uma medida socioeducativa, contemplando as metas a serem perseguidas no atendimento do adolescente, onde poderá ser verificada a evolução positiva ou negativa do menor, oferecendo parâmetro para sua reavaliação periódica. A elaboração deste plano deve resultar de avaliações psicológica, social, pedagógica, jurídica e de saúde, visando construir com o adolescente e sua família um projeto que oportunize seu desenvolvimento pessoal e social, estruturando as necessidades e atividades que auxiliarão no alcance dessas $\operatorname{metas}^{561}$.

4.2.3.3.1. Das medidas socioeducativas cumpridas em meio aberto

As medidas socioeducativas previstas no artigo 112, do Estatuto da Criança e do Adolescente podem ser divididas entre aquelas que são cumpridas em meio aberto, que são as medidas de advertência, obrigação de reparar o dano, prestação de serviços à comunidade e liberdade assistida, e as que são cumpridas com a privação ou restrição de

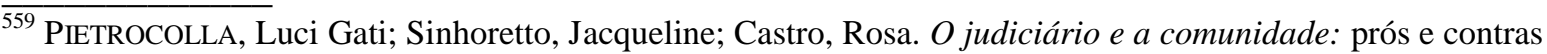
das medidas sócio-educativas em meio aberto. São Paulo: IBCCRIM - Instituto Brasileiro de Ciências Criminais, 2000. p. 15-17.

${ }^{560}$ TEIXEIRA, 2013, p. 196-198.

561 SARAIVA, 2006, p. 184-185.
} 
liberdade do adolescente, que são as medidas de internação em regime de semiliberdade e internação em estabelecimento educacional.

As medidas socioeducativas cumpridas em meio aberto devem ser escolhidas de forma preferencial às medidas privativas ou restritivas de liberdade, privilegiando a manutenção dos vínculos familiares e sociais adolescente, pois quanto mais se evitar a privação de liberdade dos jovens, mais se estará preservando o desenvolvimento saudável deles, e ainda, estar-se-á respeitando a doutrina da proteção integral ${ }^{562}$.

Quanto mais o sistema tende para as técnicas de intervenção positiva de menor grau disciplinar, maiores são as possibilidades do alcance dos objetivos da proteção integral, pois diminui a exclusão e facilita a promoção dos direitos fundamentais ${ }^{563}$.

O artigo 99, do estatuto, possibilita a cumulação dessas medidas entre si, desde que se façam compatíveis e recomendadas ao caso concreto. Esta cumulação é possível porque a carga pedagógica das medidas socioeducativas é diversa; contudo, é necessário que as medidas impostas cumulativamente desenvolvam efetivamente uma proposta pedagógica, não cabendo atribuir um caráter de dupla penalização, pois este não é o objetivo deste $\operatorname{artigo}^{564}$.

A plena realização dos programas das medidas socioeducativas não privativas ou restritivas de liberdade está vinculada, proporcionalmente, ao grau de comprometimento do juízo com a sua efetivação, pois é necessária a elaboração de convênios com entidades sociais para a organização dos programas e medidas em meio aberto ${ }^{565}$, sendo estes programas necessários, também, para ser possível uma progressão de medidas, da internação à liberdade assistida, por exemplo, assegurando a reinserção progressiva ao pleno convívio social ${ }^{566}$.

\footnotetext{
$\overline{562}$ CASTRO, A., 1998 , p. 22-24.

${ }^{563}$ VIDAL, 2002, p. 199-206.

${ }^{564}$ SARAIVA, 2006, p. 163-165.

${ }^{565}$ SPOSATO, 2006-b, p. 63-70.

566 SARAIVA, op. cit., p. 165-169.
} 
As ações desses programas devem ser planejadas e sofrer constantes avaliações para evitar que servidores despreparados apliquem técnicas carcerárias, ou meramente punitivas, que só concorrem para o recrudescimento da identidade infratora ${ }^{567}$.

Portanto, as medidas socioeducativas em meio aberto são mais benéficas, pois oferecem condições para que os adolescentes superem a prática de infrações a partir de seu compromisso pessoal, além de apresentarem custos mais baixos que a internação e índices menores de reincidência. Mas, devem contar com o compromisso do Poder Público, da comunidade e da família, para que seus objetivos sejam atingidos ${ }^{568}$.

\subsection{Advertência}

A advertência, prevista nos artigos 112, inciso I, e 115, do Estado da Criança e do Adolescente, é a mais branda das medidas socioeducativas e consiste na admoestação verbal do adolescente, pelo juiz, que deve ser reduzida a termo e assinada.

Esta medida se esgota na admoestação verbal do adolescente, restando desnecessário acompanhamento posterior dele, sendo que o adolescente deve se comprometer a não repetir a situação ${ }^{569}$.

A audiência, que deve ser especialmente pautada para isso, pode ser coletiva, devendo o ato ter um efetivo conteúdo pedagógico ${ }^{570}$, esclarecendo ao adolescente sobre as consequências que poderão advir se porventura for reincidente na prática de atos infracionais. $\mathrm{O}$ ato deve se revestir de solenidade e seriedade, e os pais ou responsáveis devem estar presentes ${ }^{571}$.

\footnotetext{
${ }^{567}$ A Ação Civil Pública, conforme artigo 210, do Estatuto da Criança e do Adolescente, é um instrumento processual de controle da execução das medidas socioeducativas, não só para situações em que a integridade de um adolescente estiver em risco, mas também quando a natureza pedagógica da medida estiver frustrada (SANTOS, D., 2012, p. 52-67).

568 SPOSATO, 2000, p. 112-114.

569 TEIXEIRA, 2013, p. 170-171.

570 SARAIVA, 2006, p. 156-157.

${ }^{571}$ ELIAS, 2008, p. 120-125.
} 
A advertência costuma ser a preferencial em caso de remissão, mas também pode ser aplicada ao fim da instrução, já que o processo, juntamente com a reiteração de seus atos, como as audiências, por exemplo, tem, também, conteúdo educativo ${ }^{572}$. Geralmente, é aplicada para infrações leves, sem consequências muito lesivas, bem como a adolescentes que não registrem atos infracionais pretéritos ${ }^{573}$.

Para que se aplique a advertência, são necessários apenas prova da materialidade e indícios suficientes de autoria, de acordo com o artigo 114, parágrafo único, do Estatuto da Criança e do Adolescente. No entanto, este dispositivo pode ser entendido como uma afronta aos direitos individuais do adolescente, pois não é possível advertir aquele que nada admite ou a quem não foi comprovada autoria. A aplicação de qualquer medida tem que ser baseada na prova da autoria e da materialidade, senão torna-se arbitrária e discricionária $^{574}$.

\subsection{Obrigação de reparar o dano}

Prevista nos artigos 112, inciso II, e 116, do Estatuto da Criança e do Adolescente, a obrigação de reparar o dano é a contraprestação feita pelo adolescente, podendo-se constituir em restituição da coisa, ressarcimento do dano ou compensação da vítima.

Ainda conforme os artigos citados acima, esta medida é aplicada em casos de atos infracionais com reflexos patrimoniais, salvo quando houver impossibilidade do adolescente de fazer a reparação, situação em que a medida poderá ser substituída por outra adequada.

Assim, como a obrigação de reparar o dano pressupõe prejuízo material à vítima ${ }^{575}$, não basta que a infração cometida pelo adolescente seja patrimonial, deve haver um reflexo patrimonial, pois esta medida tem por objetivo despertar no adolescente o senso de

\footnotetext{
${ }^{572}$ SARAIVA, 2006, p. 156-157.

573 TEIXEIRA, 2013, p. 170-171.

${ }^{574}$ SARAIVA, op. cit., p. 156-157.

${ }^{575}$ ELIAS, 2008, p. 120-124.
} 
responsabilidade social e economia em face do bem alheio, tendo, desta forma, orientação educativa $^{576}$.

A capacidade de reparação do dano deve ser do próprio adolescente, não se confundindo essa medida com a responsabilidade civil dos pais ${ }^{577}$. É necessário um agir restaurativo para que se atinja sua finalidade educativa. Portanto, se o adolescente não puder cumprir esta medida, não é permitido aos pais realizar a reparação do dano por ele. É necessário, neste caso, substituir a medida por outra não privativa de liberdade, conforme determina o artigo 116, parágrafo único, do Estatuto da Criança e do Adolescente ${ }^{578}$.

Esta medida, na sua modalidade de restituição da coisa, seria, ainda, a única exceção possível de se aplicar uma medida socioeducativa ao menor de $12 \operatorname{anos}^{579}$.

\subsection{Prestação de serviços à comunidade}

Outra modalidade de medida socioeducativa é a prestação de serviços à comunidade, prevista nos artigos 112, inciso III, e 117, da Lei Federal n n $^{\circ} .069 / 1990$, e consiste na realização de tarefas gratuitas pelo adolescente, por um período de até 6 (seis) meses, junto a entidades assistenciais, hospitais, escolas ou outros estabelecimentos congêneres, bem como em programas comunitários ou governamentais, tendo esse rol caráter meramente exemplificativo $^{580}$.

Ainda conforme a lei, as tarefas devem ser atribuídas conforme as aptidões do adolescente a elas submetido, cuja jornada máxima deve ser de 8 (oito) horas semanais, de modo a não prejudicar a frequência à escola ou à jornada normal de trabalho.

\footnotetext{
$\overline{576}$ TEIXEIRA, 2013, p. 171-173. Em razão dessa orientação educativa, pode ser admissível que o adolescente preste serviços para a vítima para compensar o prejuízo que causou (ELIAS, 2008, p. 125).

${ }^{577}$ Conforme previsto no artigo 932, incisos I e II, do Código Civil. Ademais, a obrigação de reparar o dano não significa uma responsabilidade civil aos 12 anos. O juiz, sem obrigatoriedade, tenta composição amigável entre as partes, evitando o processo cível (FIRMO, 1999, p. 90-98).

${ }^{578}$ SARAIVA, 2006, p. 157.

${ }^{579}$ FIRMO, op. cit., p. 125.

${ }^{580}$ SARAIVA, op. cit., p. 158-160.
} 
O trabalho realizado deve promover a cidadania e não expor o adolescente a condições vexatórias e humilhantes, pois sua proposta é socioeducativa. A tarefa deve implicar em um processo de conhecimento e aprendizado, devendo ser um lugar de reconhecimento $^{581}$, pois essa medida quer gerar no adolescente a compreensão de sua importância na comunidade. Por isso que o programa deve ter relação orgânica com a comunidade e a equipe técnica deve ter condições de avaliar o perfil do adolescente para expô-lo a um serviço e a um ambiente que o estimule e valorize suas potencialidades, nunca a uma situação que o frustre por incapacidade de cumprimento e que crie constrangimentos ou vexames ${ }^{582}$.

Essa medida também visa desenvolver no adolescente infrator um senso ético, despertando o sentimento de solidariedade comunitária, sendo uma medida com salutar conotação pedagógica, pois seu principal efeito é de ordem moral ${ }^{583}$. Contudo, para que assim seja, deve-se evitar o encaminhamento do adolescente para locais física e moralmente denegridos ${ }^{584}$.

Em audiência admonitória, o adolescente é cientificado de suas responsabilidades e dos objetivos buscados. Após, uma equipe técnica o avalia e o encaminha a um dos serviços disponíveis entre aqueles conveniados, cujo perfil e conveniência sejam mais adequados às suas características e aptidões, bem como à distância entre o local e sua residência e demais condições objetivas e subjetivas. Findo o prazo de cumprimento da prestação de serviços à comunidade, deve-se realizar uma nova audiência para marcar este evento, emprestando ao ato o caráter de dever cumprido, como forma de estímulo ao jovem $^{585}$.

Como já citado anteriormente, para a aplicação e execução desta medida, é necessária a realização de convênios entre o Poder Judiciário e entidades para que seja organizada a realização de tarefas adequadas às aptidões dos menores, devendo estes se organizar de maneira séria e democrática, sem objetivos totalitários ou de higiene moral ou

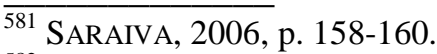

${ }^{582}$ SANTOS, D., 2012, p. 52-58.

583 TEIXEIRA, 2013, p. 173.

${ }^{584}$ ELIAS, 2008, p. 126-127.

585 SARAIVA, op. cit., p. 158-160.
} 
social, e respeitando o adolescente ${ }^{586}$, pois a intervenção e resposta do Estado devem ser cautelosas perante o risco de construir em certos jovens uma identidade criminosa ${ }^{587}$.

Conforme o artigo 112, parágrafo $2^{\circ}$, é defeso a imposição de prestação de trabalhos forçados, o que não é o caso dessa medida, desde que se atente, também, à disponibilidade do jovem para a realização dessas tarefas ${ }^{588}$.

\subsection{Liberdade assistida}

A última das medidas socioeducativas cumpridas em meio aberto é a liberdade assistida, prevista nos artigos 112, inciso IV, 118 e 119, do Estatuto da Criança e do Adolescente. Esta é a medida mais complexa, pois necessita de uma estrutura adequada para que se atinjam seus fins, que é o acompanhamento da vida familiar e social do adolescente, aliado a sua orientação e eventual auxílio ${ }^{589}$.

Para isso, designa-se um orientador, o qual incumbe, entre outras coisas, promover socialmente o adolescente e sua família, fornecendo-lhes orientação e inserindo-os, caso seja necessário, em programa oficial ou comunitário de auxílio e assistência social, promover e supervisionar a frequência escolar e diligenciar para a profissionalização do adolescente e de sua inserção no mercado de trabalho. A ajuda à família é, também, importante, pois, muitas vezes, esta se constitui o núcleo delinquencial ${ }^{590}$.

O orientador é de suma relevância, sendo ele o elo entre o adolescente que precisa de ajuda e o juiz, que deposita a confiança em alguém para prestar esta ajuda ${ }^{591}$. Desta forma, o orientador não pode se limitar a receber o jovem de vez em quando em seu gabinete, deve, de fato, participar de sua vida, com visitas domiciliares, verificação de sua condição de escolaridade e de trabalho, funcionando como uma espécie de "sombra", de

\footnotetext{
$\overline{586}$ RosA, Alexandre Morais da. Aplicando o ECA: felicidade e perversão sem limites. Revista Brasileira de Ciências Criminais, São Paulo, v. 58, p. 21-23, jan./fev. 2006.

${ }^{587}$ AlMEIDA, E.; et al., 2002, p. 180-181.

${ }^{588}$ SARAIVA, 2006, p. 163-165.

${ }^{589}$ TEIXEIRA, 2013, p. 174-175.

${ }^{590}$ SARAIVA, op. cit., p. 160-163.

${ }^{591}$ ELIAS, 2008, p. 127-130.
} 
referencial positivo e de afeto, oferecendo-lhe alternativas frente aos obstáculos próprios de sua realidade social, familiar e econômica ${ }^{592}$.

Se adequadamente executada, esta é a medida socioeducativa mais eficaz, tendo em vista a sua capacidade de intervenção na dinâmica de vida do adolescente e de sua família. Mas, para isso, é necessário qualificação e especialização, pois, do contrário, se assemelharia à suspensão condicional do processo, existente para os imputáveis ${ }^{593}$.

Ainda, uma liberdade assistida mal executada pode assumir a postura repressiva, de que tudo vigia, controla, indica, condiciona, tornando-se um processo de depuração moral que submete o jovem a um aniquilamento da autonomia ${ }^{594}$.

Normalmente, a liberdade assistida é aplicada a menores reincidentes em infrações mais leves, ou que o estudo multidisciplinar indique, ou, ainda, como progressão da semiliberdade ${ }^{595}$.

O tempo mínimo para aplicação da medida é de 6 (seis) meses, e pode valer pelo tempo que for necessária, devendo, periodicamente o orientador, defensor e Ministério Público ser ouvidos sobre a revogação, prorrogação ou substituição da medida ${ }^{596}$.

4.2.3.3.2. Das medidas socioeducativas privativas de liberdade

As medidas socioeducativas privativas de liberdade devem se reger pelos princípios da brevidade e da excepcionalidade, além de respeitarem a condição peculiar de pessoa em desenvolvimento, conforme os artigos 227 , parágrafo $3^{\circ}$, inciso $\mathrm{V}$, da carta constitucional, e 121, do Estatuto da Criança e do Adolescente.

\footnotetext{
${ }_{592}$ SARAIVA, 2006, p. 160-163.

${ }^{593}$ SARAIVA, 2006, loc. cit.

${ }^{594}$ RosA, 2006, p. 19-21.

595 ELIAS, 2008, p. 127-130. A liberdade assistida também pode ser cumulada à prestação de serviços à comunidade, pois os efeitos pedagógicos de ambas se complementam (TEIXEIRA, 2013, p. 174-175).

596 EliAS, op. cit., p. 127-130. Em sentido contrário, há posição que defende que o prazo máximo dessa medida é de 3 (três) anos de duração, ou quando o adolescente atingir 21 anos de idade (TEIXEIRA, op. cit., p. 174-175).
} 
O adolescente deve ser internado pelo menor tempo possível, pois, quanto maior o tempo de segregação, mais dessocializado tende a ficar o indivíduo ${ }^{597}$. Do internamento resultam inevitáveis sequelas que decorrem de um convívio com outros adolescentes autores de condutas infracionais mais graves, pois a capacidade de modificabilidade do adolescente é alta ${ }^{598}$.

Por ser a espécie de medida socioeducativa mais grave, a privação de liberdade deve ser reservada aos casos de maior gravidade e só aplicada quando imprescindível, pelo período mais breve possível, observando a capacidade do menor em cumprir a medida ${ }^{599}$.

Ademais, conforme os artigos 100 e 122, parágrafo $2^{\circ}$, do Estatuto da Criança e do Adolescente, o jovem só será privado de liberdade se não houver outra medida adequada, mostrando-se as demais medidas ineficazes ao caso, pois aquelas que visam ao fortalecimento dos vínculos familiares e comunitários sempre devem ser as preferidas.

Como já citado anteriormente, de acordo com o artigo 127, do estatuto, as medidas de inserção em regime de semiliberdade e internação não podem ser impostas em sede de remissão, pois exigem prova da autoria e materialidade para sua aplicação ${ }^{600}$.

Tendo em vista que a privação de liberdade, em si mesma, não representa um bem para o adolescente infrator, a internação pode configurar-se como um mecanismo de defesa social $^{601}$, podendo, assim, o internamento ser aplicado pela inexistência de alternativas e não por ser a melhor delas ${ }^{602}$.

Mesmo em privação de liberdade, deve haver para o adolescente um processo socioeducativo, conforme artigos 123 e 124, do Estatuto da Criança e do Adolescente, pois

\footnotetext{
$\overline{597}$ JUNQUEIRA, 2009, p. 95-96.

${ }^{598}$ SARAIVA, 2006, p. 170-177.

${ }^{599}$ ELIAS, 2008, p. 120-124.

${ }^{600}$ Conforme item 4.2.3.2.

601 JUNQUEIRA, op. cit., p. 95-96; MinAhIM, Maria Auxiliadora; SPOSATO, Karyna Batista. A internação de adolescentes pela lente dos tribunais. Revista Direito GV, São Paulo, v. 7, n. 1, p. 280-290, jan./jun. 2011.

${ }^{602}$ SARAIVA, op. cit., p. 170-173.
} 
a restrição de liberdade deve significar apenas limitação do exercício pleno do direito de ir e vir e não de outros direitos constitucionais ${ }^{603}$.

A escola deve ser o centro do cumprimento da medida socioeducativa privativa de liberdade, para que colabore com o regresso e permanência do jovem na rede regular de ensino. E o trabalho e as atividades de profissionalização devem ser estimulados, mas não devem ser utilizados como castigo. Devem ser representados como uma dimensão importante da vida humana, quer como fonte de sobrevivência, quer como fonte de realização profissional. Para isso, é importante a realização de parcerias com programas de formação técnico-profissional, como, por exemplo, o SENAI, para que ofereçam cursos aos internados, que considerem a colocação e as demandas do mercado de trabalho, que tenham como base um método estruturado de aprendizagem, conferindo habilidades e qualificação técnica reconhecida formalmente ${ }^{604}$.

\subsection{Semiliberdade}

A internação em regime de semiliberdade está prevista nos artigos 112, inciso V, e 120, do Estatuto da Criança e do Adolescente, e consiste no recolhimento noturno do adolescente $^{605}$, podendo ser aplicada desde o início da medida socioeducativa, se for adequada e suficiente do ponto de vista pedagógico, ou como forma de transição da internação para o meio aberto, onde o adolescente poderá visitar a família, frequentar a escola e trabalhar ${ }^{606}$.

As atividades externas, que não dependem de autorização judicial, são realizadas sem monitoramento ou vigilância, porém sujeitas a um programa previamente estabelecido, onde serão fixados horários e metas a serem alcançadas ${ }^{607}$.

\footnotetext{
${ }^{603}$ VOLPI, 1999, p. 27-28.

${ }^{604}$ Ibid., p. 34-37.

${ }^{605}$ TEIXEIRA, 2013, p. 175-176

${ }^{606}$ ELIAS, 2008, p. 130-131.

${ }^{607}$ SARAIVA, 2006, p. 177-178.
} 
Conforme o parágrafo $1^{\circ}$, do artigo 120, do Estatuto da Criança e do Adolescente, é obrigatório, durante o cumprimento desta medida, a escolarização e a profissionalização do adolescente.

A lei não prevê um prazo mínimo para a aplicação desta medida, mas não deve exceder a 3 (três) anos de duração ou 21 anos de idade, em razão do disposto no parágrafo $2^{\circ}$, do artigo 120, do estatuto, podendo, após esse prazo, caso ainda não tenha sido alcançada a idade limite, o adolescente ir para a liberdade assistida, por exemplo ${ }^{608}$.

\subsection{Internação}

A medida socioeducativa mais severa, pelo grau de interferência na esfera de liberdade individual dos jovens ${ }^{609}$, está prevista nos artigos 112, inciso VI, e 121 a 125, do Estatuto da Criança e do Adolescente, consistindo na internação do adolescente em estabelecimento educacional, exclusivo para adolescentes, sendo vedado o cumprimento desta medida em local destinado a adultos, devendo ser obedecida a separação dos internados por critérios de idade, compleição física e gravidade da infração, conforme determinação do artigo 123, desse mesmo estatuto, para evitar a formação de um ambiente pernicioso e criminógeno.

Por ser a medida mais grave, guardando conotações tanto coercitivas quanto educativas, além do respeito aos princípios da brevidade e excepcionalidade, deve ser somente destinada aos adolescentes que cometem atos infracionais graves, e ter, ainda, cunho pedagógico, não punitivo ${ }^{610}$.

A internação em si já guarda um caráter aflitivo, e, por isso, sua aplicação deve ser excepcional. Assim, mesmo que as circunstâncias do ato infracional permitam a aplicação da internação, não, necessariamente, significa escolha e autorização imediata e automática a esta medida. A imposição desta medida será somente admitida da conjunção de todos os

\footnotetext{
${ }^{608}$ ELIAS, 2008, p. 130-131.

${ }^{609}$ MinAHIM; SPOSATO, 2011, p. 280-290.

${ }^{610}$ VOLPI, 1999, p. 27.
} 
elementos e não somente da verificação se o ato é grave ${ }^{611}$, inclusive da verificação da existência de outra medida socioeducativa mais adequada.

Desta forma, esta medida deve ser aplicada aos infratores graves, com justificativa para que sejam retirados do convívio social, para que passem por um processo intensivo de reeducação ${ }^{612}$, com o objetivo de introjetar limites e construir estratégias de convivência humana socialmente aceita, de modo a nortear a vida adulta que se avizinha ${ }^{613}$.

Apesar da utilização da internação como mecanismo de defesa social, esta deve ser evitada, pois os adolescentes a ela submetidos acabam mais distantes da possibilidade de um desenvolvimento sadio, podendo ser desinternados com predisposição a condutas violentas e antissociais ${ }^{614}$.

Essa restrição da liberdade, imposta ao adolescente, deve significar apenas limitação do exercício pleno do direito de ir e vir e não de outros direitos constitucionais $^{615}$.

Conforme artigo 124, do Estatuto da Criança e do Adolescente, os adolescentes privados de liberdade, além dos demais direitos assegurados a todas as pessoas, têm alguns direitos específicos, como o de reclamar do tratamento que está sendo ministrado (incisos I a III), o de estar a par da situação processual e ser tratado com toda a dignidade (incisos IV e V), o direito à convivência familiar (incisos VI a VIII), o de ter satisfeitas suas necessidades físicas (incisos IX e X), o direito à escolarização e profissionalização (inciso XI), o direito ao desenvolvimento intelectual e espiritual (incisos XII a XIV) e o direito a devolução de documentos, para retornar a uma vida normal (inciso XV) ${ }^{616}$.

Durante a internação, é necessária a manutenção das condições gerais para o desenvolvimento do adolescente, garantindo-lhe ensino e profissionalização, sendo

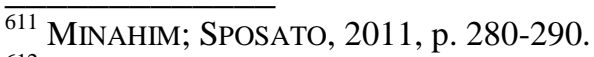

${ }^{612}$ CASTRO, A., 1998, p. 22-24.

${ }^{613}$ SARAIVA, 2006, p. 170-177.

614 TEIXEIRA, 2013, p. 176-181.

${ }^{615}$ MINAHIM; SPOSATO, op. cit., p. 280-290.

${ }^{616}$ ELIAS, 2008, p. 136-139.
} 
obrigatórias, ainda, atividades pedagógicas, conforme artigo 123, parágrafo único, do estatuto, tendo em vista o objetivo ressocializador da medida, já que o adolescente deve voltar a seu lar, à sociedade ${ }^{617}$.

Cabe, ainda, ao Estado zelar pela integridade física e mental do adolescente internado, além de adotar medidas adequadas de contenção e segurança, conforme previsão do artigo 125, da Lei Federal $\mathrm{n}^{\circ}$ 8.069/1990. Se forem torturados ou agredidos, o funcionário pode responder civil e penalmente por esses atos, e a responsabilidade do ente público também pode ser aferida, conforme artigo 37 , parágrafo $6^{\circ}$, da Constituição Federal $^{618}$.

O artigo 122, do Estatuto da Criança e do Adolescente, traz um rol taxativo das hipóteses em que pode ser aplicada a medida socioeducativa de internação. Fora dessas hipóteses, a aplicação desta medida é ilegal.

A primeira das hipóteses, prevista no inciso I, deste artigo, é a decorrente de ato infracional cometido mediante grave ameaça ou violência à pessoa, sendo que estes elementos devem integrar a conduta descrita pela norma penal ${ }^{619}$.

Ainda, não é qualquer violência ou grave ameaça que autorizam a internação, devem elas ser graves ${ }^{620}$.

A segunda hipótese que permite a aplicação da internação é a prevista no inciso II, do artigo 122, do Estatuto da Criança e do Adolescente, que trata da reiteração do cometimento de outras infrações graves, que não as do inciso anterior.

Conforme o entendimento adotado, são necessárias ao menos 3 (três) condutas graves, que são aquelas que o Código Penal comina pena de reclusão ${ }^{621}$, sendo que os atos

\footnotetext{
$\overline{{ }^{617} \text { ELIAS, 2008, p. }}$ 132-137.

${ }^{618}$ Ibid., p. 139.

${ }^{619}$ SARAIVA, 2006, p. 173-176; TEIXEIRA, 2013, p. 176-181.

${ }^{620}$ SHECAIRA, 2008, p. 210.

${ }^{621}$ SARAIVA, op. cit., p. 173-176.
} 
infracionais anteriores devem ter sentença transitada em julgado para que se possa admitir a hipóteses prevista neste artigo ${ }^{622}$.

A última hipótese de aplicação da medida de internação, prevista no artigo 122, inciso III, do estatuto, é a internação-sanção, que consiste no constrangimento do adolescente à retomada da medida socioeducativa anteriormente imposta e reiterada e injustificadamente descumprida ${ }^{623}$.

Da mesma forma que no caso anterior, são necessários 3 (três) descumprimentos injustificados para se autorizar a internação-sanção ${ }^{624}$, sendo que ela não pode ser aplicada se a medida socioeducativa não privativa de liberdade foi imposta em sede de remissão, pois não houve processo com contraditório, ampla defesa, provas da materialidade e autoria, princípios que devem ser observados com rigor quando se trata de privação da liberdade ${ }^{625}$.

É a internação-sanção que deve ser aplicada em casos de descumprimento de outra medida, e não a regressão à internação, sem prazo determinado. A regressão só é possível se o adolescente que foi primeiramente condenado à internação, se beneficiou de progressão. Se aplicar a regressão fora deste caso, estar-se-á aplicando internação com duração indeterminada, sem que houvesse qualquer processo, após do devido processo em que o jovem foi condenado à medida mais branda ${ }^{626}$.

Ao contrário das outras hipóteses de internação, nesta modalidade, o juiz pode desinternar a qualquer tempo o jovem para que ele volte ao programa de cumprimento de

\footnotetext{
$\overline{622}$ Conforme entendimento do Supremo Tribunal Federal, no julgamento do Habeas Corpus $n^{\circ}$ 88.748/SP (BRASIL. Supremo Tribunal Federal. Habeas corpus $n^{o}$ 88.748/SP, Rel.: Sepúlveda Pertence, j. 08.08.2006, DJ 29.09.2006).

${ }^{623}$ SARAIVA, 2006, p. 173-176.

${ }^{624}$ SHECAIRA, 2008, p. 212.

${ }^{625}$ ANDRADE, 2002, p. 15-16; SARAIVA, op. cit., p. 173-176.

${ }^{626}$ ANDRADE, op. cit., p. 16-20.
} 
medida socioeducativa a qual ele estava inserido ${ }^{627}$, e, conforme o artigo 122 , parágrafo $1^{\circ}$, da Lei Federal n 8.069/1990, esta medida não poderá ter prazo superior a 3 (três) meses.

Nas hipóteses de internação dos incisos I e II, deste artigo, a internação poderá perdurar por até 3 (três) anos, ou até o adolescente atingir os 21 anos de idade, conforme determinação dos parágrafos $3^{\circ}$ e $5^{\circ}$, do artigo 121, do Estatuto da Criança e do Adolescente.

A internação não tem prazo determinado, devendo sua manutenção ser reavaliada a cada 6 (seis) meses, conforme artigo 121, parágrafo $2^{\circ}$, do Estatuto da Criança e do Adolescente, detraindo-se do período mínimo para a realização da primeira reavaliação o tempo de internação provisória ${ }^{628}$.

Nesse processo, deve-se considerar a conduta institucional do menor, seus progressos e méritos, até um juízo de que o jovem faz-se apto ao retorno ao convívio social. Após a reavaliação, é necessário dar conhecimento ao adolescente das razões que concederam ou não a progressão da medida, pois esse retorno tem um efeito altamente pedagógico $^{629}$.

A indeterminação do prazo da medida socioeducativa de internação deve ser norteada pelo princípio da brevidade, reconhecendo, ainda, que cada adolescente terá um desenvolvimento único e peculiar às suas características pessoais, pois, sem tal reconhecimento, as finalidades da medida não serão atingidas e estarão sempre fadadas à imposição de mero castigo ${ }^{630}$. Contudo, deve-se ter atenção quanto às reavaliações do adolescente, pois essa indeterminação do prazo pode dar margem ampla e indesejável de

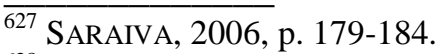

${ }^{628}$ FRASSETO, Flávio Américo. Ato infracional, medida socioeducativa e processo: a nova jurisprudência do STJ. Discursos Sediciosos: crime, direito e sociedade, Rio de Janeiro, v. 7, n. 12, p. 184-187, 2002.

${ }^{629}$ SARAIVA, op. cit., p. 184-185.

${ }^{630}$ MinAHIM; SPOSATO, 2011, p. 280-290.
} 
discricionariedade ao juiz, quando a medida deveria ser um instrumento de construção de uma proposta pedagógica eficaz ${ }^{631}$.

Caso o juiz, na sentença que determinar a internação, fixar um prazo inferior a 3 (três) anos de duração para a internação, este prazo determinado deve ser respeitado como o prazo máximo, podendo o adolescente ser desinternado antes, caso as reavaliações assim recomendem ${ }^{632}$.

Durante o período em que estiver internado, é permitida ao adolescente a realização de atividades externas, que devem ser autorizadas pela equipe técnica do estabelecimento, caso não foram vedadas pelo juiz, conforme previsão do artigo 121 , parágrafo $1^{\circ}$, do estatuto.

A atividade externa deve ser uma oportunidade de sair dos muros da instituição, não devendo ser entendida como o mero acesso ao pátio ou a área externa da unidade de internamento. Essas atividades devem se dar de forma acompanhada e monitorada, sendo que o contrário disso - a internação sem atividade externa - só deve ser aplicado se tiver na sentença a proibição, de modo fundamentado ${ }^{633}$, pois essas atividades devem integrar o projeto pedagógico da internação.

É possível, ainda, que ao adolescente sejam possibilitadas saídas, sem monitoramento, como forma de prepará-lo à progressão à semiliberdade ${ }^{634}$.

\subsection{1. Internação provisória}

Outra hipótese de internação do adolescente, que não decorre da imposição de uma medida socioeducativa, é a internação provisória, prevista no artigo 108, do Estatuto da

\footnotetext{
${ }^{631}$ SARAIVA, 2006, p. 170-173.

${ }^{632}$ FRASSETO, 2002, p. 184-187.

${ }^{633}$ SARAIVA, op. cit., p. 177-178.

${ }^{634}$ SARAIVA, 2006, p. 177-178.
} 
Criança e do Adolescente, que deve ter duração máxima de 45 dias, tempo em que deverá ser concluído o processo que apura a prática do ato infracional ${ }^{635}$.

Para que se aplique essa medida, é necessária a presença de indícios de autoria e materialidade do ato infracional, além da demonstração dos requisitos do artigo 312, do Código de Processo Penal ${ }^{636}$. Ou seja, não se deve internar provisoriamente o jovem, quando o mesmo não ocorreria com o adulto.

Nesta modalidade de internação, é possível recolher o adolescente infrator em estabelecimento destinado a adultos, em cela separada, por até 5 (cinco) dias, conforme dispõe o artigo 185, do Estatuto da Criança e do Adolescente. Após esse período o menor deve ir para o estabelecimento adequado.

4.3. Da aplicação e execução das medidas socioeducativas

Apesar da vigência do princípio da excepcionalidade e da previsão de que devem ser preferidas medidas que estimulem a formação de vínculos familiares e sociais do adolescente, há um abuso nos internamentos por infrações leves, submetendo a essa medida adolescentes sem o perfil de infrator que necessite de medida tão gravosa ${ }^{637}$.

Ainda, a maioria dos adolescentes que ingressa no sistema de justiça juvenil é internada provisoriamente por 45 dias e depois solta. Ou seja, a internação provisória é utilizada como forma de punição, mesmo que, ao fim, não se aplique a internação ${ }^{638}$.

\footnotetext{
${ }^{635}$ ELIAS, 2008, p. 113-117.

${ }^{636}$ SARAIVA, 2006, p. 176.

${ }^{637}$ Ibid., p. 165-169.

${ }^{638}$ Esta situação foi relatada pelo jornalista Fernando Rossetti ao jornal Folha de São Paulo (Disponível em: <http://www1.folha.uol.com.br/fsp/cotidian/ff13079801.htm>, acesso em 03.11.2014); e SPOSATO, 1998, p. 13-16. Conforme dados apresentados pela Fundação Casa, hoje, no estado de São Paulo, há 1.931 adolescentes em internação provisória, representando 19,9\% do total de adolescentes internados no estado (Disponível em: <http://www.fundacaocasa.sp.gov.br/pdf/Boletim/posicao_20141017.pdf〉, acesso em 03.11.2014).
} 
A internação provisória é utilizada sob o pretexto de garantir a integridade do adolescente. Mas, essa situação não seria admitida na justiça comum, um adulto não seria submetido à prisão preventiva sob o argumento de necessitar de proteção.

A diminuição da prática de atos infracionais está estritamente ligada a um funcionamento eficiente da justiça e a um cumprimento adequado do Estatuto da Criança e do Adolescente, que possibilitam a promoção de soluções criativas e resolutivas na área de atenção ao adolescente infrator ${ }^{639}$. Assim, é necessária tanto a escolha da medida socioeducativa adequada ao caso, quanto a correta execução desta.

No entanto, o sistema socioeducativo carece de efetividade, sendo necessário efetivar o modelo proposto pela lei, com o aprimoramento da norma e a qualificação de seus operadores ${ }^{640}$.

As medidas socioeducativas são mal aplicadas, do que resulta sentimento de inoperância do Estado, a partir do que afloram tendências revisionistas ou reformadoras em diversos sentidos ${ }^{641}$, pois o insucesso delas é debitado apenas ao sistema, desprezando-se a reponsabilidade concorrente do adolescente, da sua família e da comunidade ${ }^{642}$.

Faltam recursos materiais, humanos e estruturais ao Poder Executivo para executar adequadamente as medidas socioeducativas, o que não permite oferecer a retaguarda necessária para o tratamento socioeducativo. Mas, a sociedade deve, também, aceitar receber o adolescente com certa probabilidade de se adequar às condições mínimas de vida em comunidade, recepcionando o infrator após o cumprimento da medida socioeducativa, e colocando-o no caminho da adaptação ao trabalho, dos estudos e do respeito às normas da vida coletiva ${ }^{643}$.

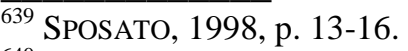

${ }^{640}$ SARAIVA, 2009, p. 120-126.

${ }^{641}$ VIDAL, 2002, p. 191-193.

${ }^{642}$ VIANNA, 2007, p. 233-236.

${ }^{643}$ Ibid., p. 221-224.
} 
Não se verifica uma aplicação integral do sistema progressivo, onde o adolescente privado de liberdade progrediria para o regime de semiliberdade e, depois, para a liberdade assistida, chegando às medidas alternativas à privação de liberdade, o que impede uma efetiva reinserção social do adolescente, dentro de uma proposta pedagógica ${ }^{644}$.

Em relação à execução das medidas socioeducativas em meio aberto, há uma carência de programas especializados para atendimento de adolescentes a elas submetidos, sendo que sua eficácia é um problema, haja vista que, geralmente, a opção por essas medidas não se dá por adesão ao modelo de intervenção positiva, mas pela suspeita de ineficácia do modelo negativo ${ }^{645}$.

Ainda, quase nenhuma importância se dá ao acompanhamento em meio aberto daquele que infracionou, mas muito se investe na construção de locais de internação, desconsiderando-se sua excepcionalidade ${ }^{646}$.

Há uma proliferação de unidades de internamento e consequente política encarceradora que apenas servem para o comprometimento da proposta expressa no Estatuto da Criança e do Adolescente, pois não atendem à excepcionalidade das medidas socioeducativas, nem à racionalidade que estas devem apresentar.

É necessário estabelecer um eficiente e eficaz sistema de atendimento ao adolescente em medida socioeducativa em meio aberto, como forma de inibir e desestimular o emprego de medidas privativas de liberdade ${ }^{647}$, pois, como se verá a seguir, estas são danosas e não contribuem para a reinserção social do adolescente.

\subsubsection{Da execução da internação}

Apesar de todos os direitos e garantias assegurados aos adolescentes, a execução da medida socioeducativa de internação se aproxima muito da execução da pena privativa de

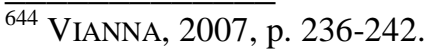

${ }^{645}$ VIDAL, 2002, p. 196-199.

${ }^{646}$ ZAPATA, 2008, p. 43-44.

${ }^{647}$ SARAIVA, 2006, p. 176.
} 
liberdade, no que se refere ao desrespeito aos direitos fundamentais da pessoa, onde se retribui o mal pelo mal. Agressões físicas e verbais são cometidas numa política à margem da lei ${ }^{648}$, sendo os adolescentes autores de atos infracionais tratados com preconceito, agressividade e repressão. Seu tratamento é simplificado a um conjunto de ações repressivas, imaginando-se que o rigor da pena possa diminuir a prática de seus atos ${ }^{649}$.

Há grande distanciamento entre a previsão legal, constante na Lei Federal $n^{\circ}$ 8.069/1990, vigente há 24 anos, e a prática das instituições encarregadas por sua aplicação, que executam a internação nos moldes da doutrina da situação irregular, em desconsideração com a proteção integral adotada pelo Estatuto da Criança e do Adolescente ${ }^{650}$.

Na mesma ocasião em que o Subcomitê de Prevenção da Tortura e outros Tratamentos ou Penas Cruéis, Desumanos ou Degradantes, da Organização das Nações Unidas, visitou o Brasil, entre 19 a 30 de setembro de 2011, para verificar a situação carcerária do país ${ }^{651}$, também visitou instituições destinadas ao cumprimento da medida socioeducativa de internação.

O órgão demonstrou grande preocupação, pois, de modo geral, violações dos direitos dos adolescentes ocorriam na maioria das instituições visitadas, além de a privação de liberdade não ser utilizada como último recurso, conforme previsão do artigo 121, do Estatuto da Criança e do Adolescente. Comentaram, ainda, sobre a semelhança existente entre estes locais de internação e a prisão destinada a adultos, sobre a rigidez do sistema disciplinar, sobre a falta de ênfase na dimensão socioeducativa do sistema juvenil e sobre a equipe técnica, que não aparentava ter treinamento especializado ${ }^{652}$.

Nestas visitas, foram identificadas, pelos membros do Subcomitê, ocorrências de abusos físicos, que muito se aproximavam da tortura. Nos locais de internação provisória,

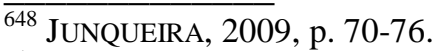

${ }^{649}$ VOLPI, 2001, p. 25-26.

${ }^{650}$ SPOSATO, 2000, p. 109-112.

${ }^{651}$ Conforme relatado no item 2.2.1

${ }^{652}$ ORGANIZAÇÃO DAS NAÇÕES UNIDAS, 2012, p. 24-25.
} 
adolescentes tinham hematomas no rosto, e, nas instituições em geral, eles sofriam tortura, maus-tratos, e práticas humilhantes, cujas lesões eram acobertadas pela equipe médica ${ }^{653}$.

Ainda em confronto com o artigo 125, do Estatuto da Criança e do Adolescente, que enuncia o dever do Estado em zelar pela integridade física e mental dos adolescentes submetidos à medida de internação, em outra ocasião, foi constatado que, nas unidades de internação de São Paulo, os adolescentes apanhavam, tinham o pescoço pisado, apresentavam marcas no corpo e fraturas devido a espancamentos. Na Unidade de Integração Três Rios, em Iaras, houve relato de que os responsáveis pelo local usavam instrumentos de tortura, como garfos, madeira, pedaço de cabo de enxada e afogamento em vaso sanitário. Alguns jovens, como forma de punição, ficavam acautelados em um quarto, mantidos isolados por até 25 dias, obrigados a ficar sentados no chão, sem direito a colchão, com as mãos para trás e cabeça baixa, sem direito a participar dos banhos de sol e do convívio com os demais internos. Os adolescentes eram, ainda, castigados e agredidos pelos funcionários por coisas banais, como não pedir licença, não virar para a parede quando um dos funcionários passasse, sendo os critérios de castigo arbitrários ${ }^{654}$.

Essas denúncias de maus-tratos e tortura foram inerentes à trajetória da FEBEM/SP, que, inclusive, já respondeu a procedimento na Corte Interamericana de Direitos Humanos em relação a isso ${ }^{655}$, sendo que essas ações repressoras continuam mesmo na nova proposta socioeducativa da Fundação Casa/SP ${ }^{656}$.

Outras violações à integridade física e mental foram percebidas nas visitas realizadas, como os comentários que os adolescentes escutavam da equipe técnica que os desqualificavam, além de sofrerem tortura psicológica promovida pelos funcionários, e

\footnotetext{
${ }^{653}$ ORGANIZAÇÃO DAS NAÇÕES UNIDAS, 2012, p. 24-28.

${ }^{654}$ COLETIVO EM DEFESA DOS DIREITOS DO(A) JOVEM PRIVADO(A) DE LIBERDADE NA FEBEM/FCASA. Relatório de fiscalização às unidades de internação em estabelecimento educacional da Fundação Casa - SP, dezembro de 2008. p. 24-35.

${ }^{655}$ A Corte Interamericana de Direitos Humanos acompanhou o caso que ficou conhecido como "Complexo do Tatuapé", onde determinou algumas medidas que o Estado deveria tomar para que a vida e a integridade física dos adolescentes internados no Complexo do Tatuapé, da antiga FEBEM /SP, fossem resguardadas. Disponível em: <http://www.corteidh.or.cr/docs/medidas/febem_se_03_portugues.pdf>, acesso em 10.10.2014.

${ }^{656}$ A alteração da denominação das unidades de internação em São Paulo ocorreu com a Lei Estadual $n^{\circ}$ $12.469 / 2006$
} 
ficarem ameaçados constantemente ${ }^{657}$. Na unidade de internação Viana II, no Espírito Santo, os adolescentes estavam internados em instituição que se assemelhava a instituição de segurança máxima, sendo que alguns estavam fortemente medicados ${ }^{658}$.

Superlotação e instalações físicas precárias ou inadequadas também são comuns em estabelecimentos de internação de adolescentes infratores.

Na unidade masculina, do Complexo da Vila Maria, em São Paulo, por exemplo, foi constatado que os banheiros não tinham qualquer privacidade, nos quartos havia foco de infiltração de água e mofo, no refeitório havia goteiras, e os adolescentes não podiam mudar de lugar para impedir que a comida encharcasse ${ }^{659}$, desrespeitando a disposição do artigo 124, inciso X, do Estatuto da Criança e do Adolescente.

O projeto arquitetônico das unidades de internação deveria ser compatível com a dignidade dos internados. Assim, a segurança deveria ser aquela necessária a essa finalidade, as unidades deveriam ser para um número reduzido de adolescentes, com alojamentos individuais, local para guarda de objetos pessoais com segurança, os banheiros deveriam preservam a intimidade, celas de segurança somente para casos de ameaça à integridade física ${ }^{660}$.

Mesmo sendo um direito trazido no inciso IX, do artigo citado acima, os adolescentes também não têm acesso aos objetos adequados necessários à higiene e asseio pessoal $^{661}$. Conforme o verificado, o tempo total de banho permitido aos adolescentes, na unidade referida acima, era de menos de 4 minutos, os produtos de higiene pessoal não

\footnotetext{
${ }^{657}$ Coletivo em Defesa dos direitos do(A) Jovem PRivado(A) DE Liberdade na FEBEM/FCASA, 2008, p. 24-35.

658 ORGANIZAÇÃO DAS NAÇÕES UNIDAS, 2012, p. 24-28. Cada vez mais tem sido utilizada medicação para conter, restringir e alienar o adolescente, em nome da pertinência pedagógica (ROSA, 2006, p. 21-23).

${ }^{659}$ COLETIVO EM DEFESA DOS DIREITOS DO(A) JOVEM PRIVADO(A) DE LIBERDADE NA FEBEM/FCASA, op. cit., p. 95-105.

${ }^{660}$ VOLPI, 1999, p. 38-40.

${ }^{661}$ ORGANIZAÇÃO DAS NAÇÕES UNIDAS, op. cit., p. 24-28.
} 
eram regularmente oferecidos, nem tinham qualidade adequada, e os adolescentes ficavam vários dias com a mesma roupa ${ }^{662}$.

Não foi constatada a atenção necessária à saúde dos adolescentes, que, caso necessitassem de algum remédio, tinham que aguardar dias para a chegada do médico ${ }^{663}$, além da falta de tratamento para a drogadição e dos jovens com doença mental, que não eram transferidos para locais adequados, nem recebiam o devido tratamento ${ }^{664}$.

Foram verificadas, ainda, outras violações, como a falta de informações aos adolescentes sobre o andamento do processo judicial deles, a ausência de visita dos promotores e juízes nos estabelecimentos de internação, alimentação de baixa qualidade e leitos inadequados ${ }^{665}$.

Na unidade feminina, do Complexo da Vila Maria, em São Paulo, as adolescentes eram obrigadas a participar de atividades de cunho religioso que constavam na grade de atividades normais da unidade ${ }^{666}$, contrariando o artigo 124, inciso XIV, do Estatuto da Criança e do Adolescente.

Na Unidade de Integração Três Rios, em Iaras, as orientações no que se referiam à segurança continuavam seguindo as diretrizes da FEBEM, apesar da divulgação da existência de um novo modelo político pedagógico, motivo pelo qual havia uma inadequação na pretensão socioeducativa, que foi encontrada em diversas unidades de internação $^{667}$.

\footnotetext{
$\overline{662}$ Coletivo EM DEFESA DOS DIREITOS DO(A) JOVEM PRIVADO(A) DE LIBERDADE NA FEBEM/FCASA, 2008, p. 95-105.

${ }^{663}$ Coletivo EM DEFesa dos DiReItos DO(A) JOVEM PRIVAdO(A) DE LIBERDADE NA FEBEM/FCASA, 2008, loc. cit.

${ }^{664}$ Ibid., p. 16-23.

${ }^{665}$ ORGANIZAÇÃO DAS NAÇõeS UNIDAS, 2012, p. 24-28.

${ }^{666}$ COLETIVO EM DEFESA DOS DIREITOS DO(A) JOVEM PRIVADO(A) DE LIBERDADE NA FEBEM/FCASA, $o p$. cit., $p$. 105-112.

${ }^{667}$ Ibid., p. 16-19, 24-35.
} 
Os agentes responsáveis pela segurança dos adolescentes não passavam de carcereiros sem nenhuma carga pedagógica para formação da cidadania ${ }^{668}$.

Deveria haver um severo controle das atividades das unidades de internação, por comitês ou conselhos comunitários, de modo a contribuir no controle da qualidade dos serviços prestados e serem inibidas violações aos direitos dos adolescentes ${ }^{669}$.

Da mesma forma que acontece no cumprimento da pena privativa de liberdade, os familiares passavam por revistas íntimas humilhantes e vexatórias para ter acesso ao adolescente $^{670}$. Além disso, a família do adolescente infrator acaba sendo criminalizada pelas instituições, tendo um tratamento similar ao dispensado aos seus filhos ${ }^{671}$.

A família também deveria estar envolvida integralmente na dinâmica institucional, criando-se cumplicidade entre a família e a instituição na responsabilidade de levar o adolescente a repensar seus valores, suas atitudes, seu modo de ver e viver o mundo, o que promoveria melhores resultados ${ }^{672}$. É por isso que o artigo 124, inciso VI, do Estatuto da Criança e do Adolescente, determina que o adolescente que esteja cumprindo medida socioeducativa de internação permaneça internado na mesma localidade ou naquela mais próxima ao domicílio de seus pais ou responsáveis, de modo a, por exemplo, facilitar e estimular as visitas. Contudo, nem sempre essa disposição é respeitada, sendo os jovens internados distantes de seus familiares, que, às vezes, deixam de visitar seus filhos por não ter condições de arcar com o transporte para outra localidade ${ }^{673}$.

Em relação a profissionalização que deveria ser oferecida aos adolescentes internados, nas unidades de internação, não há curso formal que desperte o interesse dos

\footnotetext{
668 Estes profissionais deveriam passar por programa de capacitação, voltado às especificidades dos adolescentes submetidos a sua orientação e ser submetidos a estratégias de capacitação e valorização, e atividades de descontração e lazer (VOLPI, 1999, p. 37-38).

${ }^{669}$ VOLPI, op. cit., p. 41-42.

${ }^{670}$ Coletivo EM DEFESA dos DiReitos DO(A) JOVEM PRIVADO(A) DE LiBERDADE NA FEBEM/FCASA, 2008, p. 16-23.

${ }^{671}$ RESENDE FILHO, José. Família e as medidas sócio-educativas. Revista do ILANUD, São Paulo, n. 14, p. 3941, 2001.

${ }^{672}$ RESENDE FILHO, 2001, loc. cit.

${ }^{673}$ COlETIVO EM DEFESA dos DiREITOS DO(A) JOVEM PRIVADO(A) DE LIBERDADE NA FEBEM/FCASA, op. cit., p. 24-35.
} 
jovens, e os cursos profissionalizantes existentes não têm utilidade para suas vidas, ou exigem um nível de escolaridade que os jovens ainda não atingiram ${ }^{674}$, indo de encontro com qualquer proposta pedagógica.

Além de os cursos profissionalizantes serem de baixa remuneração no mercado de trabalho, tais como doceiro, atendente de farmácia, confecção de velas aromáticas e decorativas, hotelaria e turismo, salgadeiro, cozinha regional brasileira, foi constatada que a qualidade deles era precária, não apresentando grandes possibilidades de servir como base para profissão, e as técnicas de aprendizado eram, também, inadequadas, não permitindo ao jovem desenvolver aptidão para alguma profissão que poderia ser a base de retorno ao convívio social ${ }^{675}$.

Conclui-se, assim, que a internação, além de desrespeitar a integridade física e psicológica do adolescente, não é executada visando à prevenção, educação e profissionalização do jovem, constituindo-se, desta forma, ferramenta de reforço da exclusão a que muitos adolescentes estão expostos, que reforça a negligência já conhecida por parte deles, quando não aperfeiçoa a segregação, por intermédio de práticas de violência, humilhação e constrangimentos ${ }^{676}$.

Estas instituições segregam e não oferecem condições de reinserção dos jovens na sociedade, agravando a situação de marginalização na qual eles se encontram, além de aumentar seu contato com a criminalidade e as chances reincidência ${ }^{677}$.

A privação de liberdade é, então, do modo que é executada, medida aflitiva e expiacionista, cuja configuração em termos de defesa social a converte em pena ${ }^{678}$.

Além do tratamento oferecido nas unidades de internação, que fere a dignidade do adolescente e viola seus direitos fundamentais, e da proposta pedagógica realizada, que não

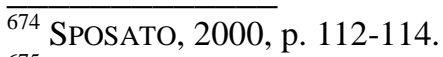

${ }^{675}$ COLETIVO EM DEFESA DOS DIREITOS DO(A) JOVEM PRIVADO(A) DE LIBERDADE NA FEBEM/FCASA, $2008, \mathrm{p}$. 95-105.

${ }^{676}$ SPOSATO, 2006-a, p. 138.

${ }^{677}$ SPOSATO, 1998, p. 13-16.

${ }^{678}$ ABEL SOUTO, 2002, p. 106-107.
} 
contribui para o sadio retorno ao convívio social do menor, a privação de liberdade ainda causa efeitos perversos ao internado, dadas suas características de instituição total ${ }^{679}$, sendo, desta forma, excessivamente danosa à pessoa em desenvolvimento e pouco eficaz enquanto estratégia pedagógica ${ }^{680}$.

O jovem acaba institucionalizado, sendo obrigado a seguir diversas restrições e imposições. $\mathrm{O}$ adolescente deve se submeter a uma condição de passividade e rotulação, em uma instituição que reproduz todas as características penitenciárias, sendo padronizados, afrontando a pretendida individualização, um dos objetivos que deveria ser buscado para se alcançar melhores resultados. Sofrem também da carcerização, fazendo esses efeitos presentes no modo de falar e gesticular, na hierarquização, no uso de gírias, na adesão a um partido interno da instituição ${ }^{681}$.

A institucionalização acompanha o indivíduo, bem como a desculturação, já que estigmatizam, dificultando a recolocação desses jovens na sociedade ${ }^{682}$.

A indeterminação temporal da media socioeducativa também pode por em xeque o trabalho socioeducativo e trazer efeitos negativos à pessoa internada, pois o que está em jogo para a conquista da liberdade acaba sendo a mudança da personalidade do adolescente, em desrespeito a sua dignidade e do direito de ser aquilo que ele é ${ }^{683}$. Ainda, as reavaliações que devem ser feitas a cada 6 (seis) meses para decidir sobre a manutenção da internação, não têm critérios bem definidos, deixando espaço para o arbítrio do magistrado, que pode manter um adolescente internado por até 3 (três) anos, sem que essa seja a medida mais adequada naquele momento.

Como o tempo de duração da medida socioeducativa não está na sentença, a possibilidade de elaborar um Plano Individual de Atendimento, que atenda às necessidades de cada adolescente, ficam diminuídas, pois não é possível elaborar uma proposta

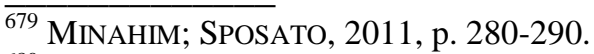

${ }^{680}$ FRASSETO, 2002, p. 170-171.

681 JUNQUEIRA, 2009, p. 99-102.

${ }^{682}$ ZAPATA, 2008, p. 45-47.

${ }^{683}$ Ibid., p. 44-45.
} 
socioeducativa individualizada que se harmonize com o tempo que o adolescente ficará internado.

Ademais, apesar de possível, não há previsão legal a respeito da progressão das medidas socioeducativas, de um regime mais severo para um mais brando, o que não permite aos jovens um trabalho socioeducativo contínuo, pois a progressão fica ao arbítrio do julgador, que pode utilizá-la apenas para manter o jovem sob a justiça juvenil, após o cumprimento dos 3 (três) anos de internação, sem uma efetiva finalidade de reinserção social.

Assim, os ambientes de internação são nocivos e trazem influências negativas àqueles que praticaram infrações, às vezes, não tão graves. Isso reflete, posteriormente, no comportamento do jovem com a sociedade quando solto, pois tem muita chance de voltar a delinquir $^{684}$.

4.3.2. A aplicação da doutrina da situação irregular pelos tribunais

Como visto acima, prevalece uma política de encarceramento dos adolescentes infratores, em detrimento da aplicação de medidas socioeducativas em meio aberto. Uma das razões para que isso ocorra é a persistência da doutrina da situação irregular em nossos tribunais.

Há um legado da exagerada atitude assistencial, que tem consentido que as práticas judiciais atuais sejam inspiradas no modelo anterior, havendo hesitação em adotar um modelo amplamente garantista para o adolescente, o que tem permitido a discricionariedade na apuração da infração praticada e aplicação da medida socioeducativa $^{685}$.

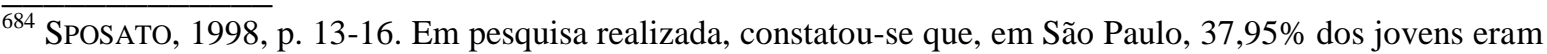
reinternos; e, no Rio de Janeiro, 30,35\% (CASTRO, A., 1998, p. 22-24).

${ }^{685}$ MinAHIM; SPOSATO, 2011, p. 290-294.
} 
Verifica-se que o Estatuto da Criança e do Adolescente passa hoje por uma dupla crise, de implementação e de interpretação. A crise de implementação consiste na carência de saúde e de educação e mau uso dos recursos dedicados a gastos sociais. Já a crise de interpretação vincula-se mais às "boas" práticas tutelares e compassivas, com a persistência de uma cultura de subjetivismo e discricionariedade ${ }^{686}$.

Geralmente, os adolescentes infratores são pessoas humildes e cometem práticas decorrentes da própria marginalização, o que leva à crise de interpretação do estatuto, que é a falsa percepção de que a internação constitui-se em uma benesse e reveste-se de caráter protetivo, afastando sua verdadeira índole penal e os limites ao poder de punir que deveriam ser exercitados nesse campo ${ }^{687}$.

A crise de interpretação do Estatuto da Criança e do Adolescente vincula-se, assim, a presença marcante de argumentos extrajurídicos e ideológicos ${ }^{688}$, se configurando como uma releitura subjetiva e discricionária das disposições garantistas do Estatuto da Criança e do Adolescente ${ }^{689}$.

A substituição do Código de Menores pelo Estatuto da Criança e do Adolescente resultou numa verdadeira troca de paradigma, que quer erradicar de forma definitiva as más práticas autoritárias e repressivas, pois as piores atrocidades contra a infância foram cometidas muito mais em nome do amor e compaixão do que da própria repressão. No amor, não há limites; na justiça, $\operatorname{sim}^{690}$.

Contudo, os juízes, ao imporem a internação, fazem uma correlação da prática do ato infracional grave com a existência de desajuste social e moral, demonstrando uma visão estereotipada dos adolescentes. Fazem menções a condições pessoais do adolescente como impeditivas ao cumprimento de medida socioeducativa em meio aberto e as condições pessoais do adolescente operam de forma mais intensa do que a verificação de sua conduta, configurando um direito penal do autor nesses procedimentos e dando

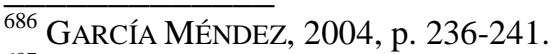

${ }^{687}$ MINAHIM; SPOSATO, 2011, p. 277-280.

${ }^{688}$ MINAHIM; SPOSATO, 2011, loc. cit.

${ }^{689}$ GARCÍA MÉNDEZ, op. cit., p. 241-243.

${ }^{690}$ Ibid., p. 236-241.
} 
margem a políticas repressivas e irracionais, tornando o adolescente mero objeto da justiça juvenil e desrespeitando os seus direitos ${ }^{691}$.

Afastam-se, também, as regras e garantias processuais penais, sob o argumento de tratar-se de sistema diferenciado com fundamento na proteção integral, equiparando a medida socioeducativa à medida protetiva, negando caráter penal e sancionatório à primeira, atribuindo-lhe índole meramente segregadora e mitigando o caráter pedagógico que a internação deve contemplar ${ }^{692}$. Essa operação legitima incontáveis violações dos direitos dos adolescentes processados ${ }^{693}$.

Para superar esse modelo tutelar é necessário, portanto, assumir que os sistemas de responsabilidade são sistemas penais ${ }^{694}$ e que os adolescentes são penalmente responsáveis.

O não reconhecimento do conteúdo penal das sanções permite que se sancione, não os fatos ou atos praticados, mas a subjetividade dos adolescentes e sua condição de existência. Tem-se como finalidades, assim, a prevenção especial positiva, de reeducação do réu, e negativa, de sua eliminação ou neutralização. Deve-se reconhecer, portanto, a natureza penal da medida socioeducativa, para que as garantias penais e processuais dos adolescentes sejam respeitadas $^{695}$.

Um exemplo de como se dá essa interpretação sobre o Estatuto da Criança e do Adolescente é a imposição da medida socioeducativa de internação em caso de ato infracional equiparado ao tráfico ou porte de entorpecentes.

Apesar de não se enquadrar nas hipóteses de aplicação da medida de internação, do artigo 122, do estatuto, a menos que seja caso de ações graves reiteradas, os magistrados impõem medida de internação ao ato infracional equiparado ao tráfico de drogas, sob a

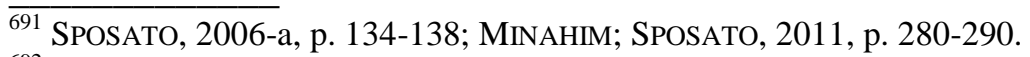

${ }^{692}$ MINAHIM; SPOSATO, 2011, loc. cit.

${ }^{693}$ FRASSETO, 2002, p. 168-169.

${ }^{694}$ LERNER, Gabriel. Sistema integral de justicia penal para adolescentes: la necesidad de una reforma transicional. Revista de derecho penal y procesal penal, Buenos Aires, n. 7, p. 1183-1186, jul. 2009.

${ }^{695}$ SPOSATO, op. cit., p. 143-149.
} 
justificativa de que há uma violência presumida contra toda a sociedade na prática desta infração, como forma de legitimação e adequação legal para a imposição da privação de liberdade ${ }^{696}$.

Antes do Estatuto da Criança e do Adolescente, não era necessária tal prática interpretativa, pois, através das medidas previstas pelo Código de Menores, era possível impor aos adolescentes uma sanção por aquilo que não era crime para os adultos, como o caso de posse de entorpecentes para uso próprio, que, até 1971, conforme a redação original do artigo 281, do Código Penal, não era uma conduta típica ${ }^{697}$.

Já se via, desde então, a atuação seletiva do sistema penal para jovens das classes sociais mais baixas, que recebiam um tratamento diverso dos jovens das classes mais altas quando se tratava de posse ou tráfico de entorpecentes, criminalizando-os e fazendo com que superlotassem as unidades de internação de adolescentes infratores ${ }^{698}$.

Em dados apresentados em 2012, pelo Conselho Nacional de Justiça, constatou-se que $32 \%$ dos jovens internados na região Sudeste cumpriam a medida em razão da prática de ato infracional equiparado ao tráfico de drogas. A média no Brasil era de $24 \%{ }^{699}$.

Os adolescentes que cometem essa infração estão sendo submetidos à internação, mesmo a lei vedando a imposição de medida privativa de liberdade neste caso, pois não há grave ameaça ou violência na ação perpetrada ${ }^{700}$.

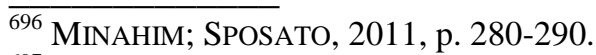

${ }^{697}$ BATISTA, Vera Malaguti. Difíceis ganhos fáceis: drogas e juventude pobre no Rio de Janeiro. $2^{\mathrm{a}}$ ed. Rio de Janeiro: Revan, 2003. p. 86.

${ }^{698}$ Ibid., p. 134-135. Nesta obra é possível observar como as drogas ganharam espaço na criminalidade juvenil e como o tratamento dado àqueles de classes sociais mais avantajadas era diferente, permitindo, nestes últimos casos, uma abordagem não criminal.

${ }^{699}$ CONSElHO NACIONAL DE JuSTiÇA. Panorama Nacional - A execução das medidas socioeducativas de internação, Programa Justiça ao Jovem, 2012, p. 11. Disponível em: < http://www.cnj.jus.br/images/pesquisasjudiciarias/Publicacoes/panorama_nacional_doj_web.pdf>, acesso em 02.11.2014. Em levantamento realizado no mesmo ano, constatou-se que $42 \%$ das internações ocorridas no estado de São Paulo eram decorrentes do tráfico de drogas (Disponível em: <http://www.estadao.com.br/noticias/geral,faltam-vagas-na-fundacao-casapor-internacao-por-trafico,933796>, acesso em 02.11.2014).

${ }^{700}$ SARAIVA, 2006, p. 173-176. Apesar de os juízes e tribunais manterem esse entendimento, o Superior Tribunal de Justiça manifestou entendimento, no enunciado 492, de sua Súmula, no sentido de que "o ato
} 
Desta forma, a medida socioeducativa de internação está sendo imposta sem os requisitos legais exigidos pelo Estatuto da Criança e do Adolescente e sem a observância do devido processo legal ${ }^{701}$. A medida de segurança aplicada desta forma constitui ferramenta de reforço da exclusão, a que muitos adolescentes já estão expostos, trazendo, ainda, um discurso compensatório de políticas sociais e uma ideologia correcional $^{702}$.

Ainda que o juiz tenha discricionariedade para escolher a medida socioeducativa adequada ao caso, essa escolha não é arbitrária, tendo em vista que ele deve observar os parâmetros normativos do Direito Penal Juvenil ${ }^{703}$.

Desta forma, sem a aplicação de um Direito Penal Juvenil com todas as garantias que lhe são inerentes, não se resguarda o direito à liberdade dos adolescentes, conforme determina o artigo 227, da Constituição Federal, pois são retiradas da medida socioeducativa de internação a excepcionalidade e a racionalidade que ela deve ter.

\subsection{A Unidade Experimental de Saúde}

No estado de São Paulo, foi criado um novo regime de internamento para adolescentes egressos da Fundação Casa em razão de terem completados 21 anos, conforme determina o artigo 121, parágrafo $5^{\circ}$, do Estatuto da Criança e do Adolescente.

infracional análogo ao tráfico de drogas, por si só, não conduz obrigatoriamente à imposição de medida socioeducativa de internação do adolescente". No entanto, a dinâmica acelerada dos fatos na justiça da infância e da juventude, contraposta à lentidão habitual das instâncias superiores, enseja que apenas parcela mínima das decisões ilegais acabe sendo corrigida e, ainda, a destempo, não impedindo, mesmo nos casos de reforma da decisão, que os adolescentes permaneçam longo período internados quando deveriam estar cumprindo medida socioeducativa em meio aberto (FRASSETO, 2002, p. 167-168). Os Habeas Corpus $\mathrm{n}^{\circ}$ 299.257/SP e 271.466/SP demonstram exemplos de decisões recentes, em que se reconheceu a ilegalidade da imposição da medida de internação em decorrência de ato infracional equiparado a tráfico de drogas (BRASIL. Superior Tribunal de Justiça. Habeas corpus $n^{\mathbf{o}}$ 299.257, da $6^{\mathbf{a}}$ Turma, Rel.: Ministro Nefi Cordeiro, j. 09.09.2014, DJe 25.09.2014; BRASIL. Superior Tribunal de Justiça. Habeas corpus n ${ }^{\mathrm{o}} 271.466$, da $5^{\mathrm{a}}$ Turma, Rel.: Ministro Feliz Fischer, j. 16.09.2014, DJe 25.09.2014).

${ }^{701}$ Tramita no Senado o Projeto de Lei do Senado $\mathrm{n}^{\mathbf{0}} 107 / 2003$, que tem por objetivo alterar o inciso I, do artigo 122 do Estatuto da Criança e do Adolescente, para permitir a internação do adolescente quando ele for integrante de organização criminosa ou tiver envolvimento com o tráfico de drogas.

702 MINAHIM; SPOSATO, 2011, p. 293-294.

${ }^{703}$ TEIXEIRA, 2013, p. 199-200. 
Este novo internamento é realizado no estabelecimento denominado Unidade Experimental de Saúde, cuja criação teve grande apoio social, pois, em tese, respondia aos reclamos de segurança e de maior rigorosidade na imposição de penas aos adolescentes ${ }^{704}$.

Os reclamos públicos correspondiam à manutenção da internação de um adolescente, que, em 2003, praticou um ato infracional grave, caso que tomou grande repercussão e comoção social.

Após ele completar 21 anos, quando não poderia mais ficar internado sob os regramentos do Estatuto e do Adolescente, foi determinada, em 2007, a interdição civil dele, por um juiz da Vara da Família e Sucessões, cumulada com internação hospitalar compulsória, tendo em vista a existência de laudo que apontava que ele sofria de transtorno de personalidade e apresentava alta probabilidade de reincidência, e, por isso, precisava de um tratamento médico que demandava contenção ${ }^{705}$. Assim, ele foi transferido para a Unidade Experimental de Saúde, onde permanece internado até hoje.

Depois dele, essa unidade recebeu mais alguns jovens com o mesmo diagnóstico, que seguem lá internados, supostamente para receber tratamento médico em razão dos distúrbios psicológicos que sofrem. Nota-se que, apesar de o diagnóstico utilizado para justificar a internação na Unidade Experimental de Saúde, esses jovens cumpriam, anteriormente, medida socioeducativa, em estabelecimento de internação, sem receber tratamento médico em estabelecimento adequado, como determina o artigo 112, parágrafo $3^{\circ}$, do Estatuto da Criança e do Adolescente.

Esta unidade, que, primeiramente, pertencia à Fundação Casa, foi transferida para a Secretaria da Saúde pelo Decreto Estadual no 52.419/2007/SP, sendo a Unidade Experimental de Saúde criada com o Decreto Estadual no 53.427/2008/SP, não havendo lei

\footnotetext{
$\overline{704}$ VIANNA, 2007, p. 233-236.

${ }^{705}$ Informações disponíveis em: 〈http://www.ibccrim.org.br/noticia/13822-Unidade-Experimental-de-Saude〉, acesso em 13.10.2014.
} 
disciplinadora dos procedimentos de competência desta unidade, motivo pelo qual não há parâmetros de regulação e garantia ${ }^{706}$.

Conforme o artigo $2^{\circ}$, inciso I, do último decreto, essa unidade é destinada para jovens com diagnóstico de distúrbio de personalidade e com alta periculosidade, podendo essas pessoas ser as egressas da Fundação Casa, que cometeram atos infracionais graves, ou que foram interditadas civilmente, e que necessitam de tratamento psiquiátrico em regime de contenção. Ressalva-se que a utilização do termo "periculosidade" para justificar a segregação da pessoa que cometeu ato infracional grave remete a um direito penal do autor, pois a medida é imposta em razão da condição pessoal do adolescente e não de sua culpabilidade $^{707}$.

Segundo a legislação, o objetivo desta internação é oferecer as condições necessárias para o tratamento daquele que cumpriu a medida socioeducativa de internação, sem natureza penal, já que, inclusive, a unidade é de responsabilidade da Secretaria da Saúde. Se não se reconhece caráter penal à medida, deixa-se de aplicar todos os direitos e garantias decorrentes desse reconhecimento, inclusive, a proibição de penas perpétuas.

Contudo, no local, não há tratamento médico adequado àqueles que lá se encontram, nem um projeto terapêutico. Ainda, além de a internação ser decorrente da prática de um ato infracional anterior, os funcionários responsáveis pela guarda e segurança dos jovens são servidores cedidos da Secretaria de Administração Penitenciária, apesar de a unidade pertencer à Secretaria de Saúde, o que demonstra que os jovens lá internados têm tratamento que se assemelha ao que eles recebiam na Fundação Casa, mas sem a proposta socioeducativa; ou seja, estão internados em local com viés punitivo ${ }^{708}$.

\footnotetext{
$\overline{706}$ SANTORO FILHO, Antonio Carlos. Internações involuntárias ou perpétuas: a questão da unidade experimental de saúde, mai, 2013. Disponível em <http://jus.com.br/artigos/24356/internacoes-involuntariasou-perpetuas-a-questao-da-unidade-experimental-de-saude>, acesso em 06.10.2014.

707 SANTORO FILHO, 2013.

${ }^{708}$ PAUKOSKI, Mônica Ribeiro de Souza. Interface da Saúde Mental em questão de Justiça e o ponto de vista do Poder Judiciário. In: Conselho Regional de Psicologia DA 6a REgião (org.). Políticas de saúde mental e juventude nas fronteiras psi-jurídicas, São Paulo: CRP SP, 2011. p. 15-20; informações também disponíveis em: <http://www.istoe.com.br/reportagens/135118_PRISAO+PERPETUA+A+BRASILEIRA>, acesso em 13.10.2014, e <http://www1.folha.uol.com.br/fsp/cotidian/ff2803201110.htm>, acesso em 13.10.2014.
} 
E mais, mesmo que se tratasse de uma internação de natureza sanitária, esta medida contrariaria os princípios trazidos pela reforma psiquiátrica, na Lei Federal no 10.216/2001, pois se trata de instituição de características asilares, onde não se busca um tratamento extra-hospitalar, preparando a pessoa para o retorno à sociedade, nem vivência comunitária, o que vai de encontro com o artigo $4^{\circ}$, parágrafo $3^{\circ}$, desta lei.

Assim, o internamento na Unidade Experimental de Saúde desrespeita os direitos individuais das pessoas lá internadas, pois o novo encarceramento não é precedido de um crime e um devido processo legal, e ocorre após a responsabilização de ato infracional anterior, onde o adolescente já cumpriu a medida anteriormente imposta, havendo, portanto, uma penalização dupla pelo mesmo fato, além de desrespeitar o princípio da anterioridade penal. Ademais, esse internamento não comporta prazo de duração, perdurando enquanto for conveniente, não encontrando guarida legal ${ }^{709}$.

O jovem é internado na Unidade Experimental de Saúde após cumprir uma pena de acordo com a sua culpabilidade - medida socioeducativa, sendo a nova prisão perpétua, com fim inocuizador, afetando, desta forma, os direitos fundamentais da pessoa internada, e indo de encontro ao princípio da humanidade ${ }^{710}$.

Percebe-se, desta forma, que a Unidade Experimental de Saúde ressuscita o sistema duplo-binário, pois há a aplicação cumulativa de medida socioeducativa com tratamento psiquiátrico coercitivo, com base num diagnóstico que recomenda cuidado e controle ${ }^{711}$.

É, também, uma medida pré-delitual, dirigida a jovens infratores, tendo em vista sua alta possibilidade de reincidência e periculosidade, medida esta que já foi abolida do

\footnotetext{
$\overline{709}$ Maglio, Maria Fernanda dos Santos Elias. Da medida de segurança e da medida sócio-educativa: as semelhanças entre os destinos conferidos aos adolescentes e loucos autores de delitos. Revista da Defensoria Pública, São Paulo, Ed. especial, n 3, p. 87-88, 2008.

${ }_{710}$ Gracia MARTín, 2008, p. 996-1000.

${ }^{711}$ MAGLIO, op. cit., p. 87-88.
} 
Código Penal e que remonta à doutrina da situação irregular, sendo, portanto, um precedente e abertura ao arbítrio, incompatível com o Estado Democrático de Direito ${ }^{712}$.

A internação é decretada pelo juiz cível, não observando os princípios e garantias penais, e, portanto, pode assumir o caráter perpétuo ${ }^{713}$. Ressalta-se que, no sistema, não há previsão de reavaliação da medida, não tendo o jovem internado qualquer perspectiva de liberação ${ }^{714}$, o que torna a internação excessivamente aflitiva.

Assim, os jovens que lá estão internados, não recebem tratamento socioeducativo, como educação e profissionalização, pois não se trata de uma medida socioeducativa, não recebem tratamento médico adequado a sua condição, e não têm prazo para deixar o local. Constitui-se a Unidade Experimental de Saúde, desta forma, instrumento de mera inocuização da pessoa, que apresenta periculosidade, deixando ela de ser um sujeito de direito para ser objeto da intervenção punitiva estatal, negando a ela, assim, sua dignidade.

Este é um exemplo de medida simbólica, que somente agrada a sociedade, calcando seu clamor, sem que se tenha verificado a utilidade reabilitadora desse sistema, infringindo direitos e garantias individuais ${ }^{715}$, e possibilitando a criação de espaços de custódia ao arrepio da $1 \mathrm{ei}^{716}$.

O Subcomitê de Prevenção da Tortura e outros Tratamentos ou Penas Cruéis, Desumanos ou Degradantes, da Organização das Nações Unidas, visitou este local e demonstrou grande preocupação com os jovens lá internados, em razão da indeterminação do tempo de internação. O órgão expressou preocupação com a situação legal dessas pessoas e com o sofrimento mental que uma internação sem prazo definido pode causar; e recomendou que a unidade seja desativada e que as determinações do Estatuto da Criança e

\footnotetext{
$\overline{712}$ SANTORO FILHO, 2013.

${ }^{713}$ SANTORO FILHO, op. cit.

${ }^{714}$ FrASSETO, Flávio Américo. Fronteiras psi-jurídicas dos casos de interdição em andamento em São Paulo e a questão da Unidade Experimental de Saúde. In: ConselHo REGIONAL DE PSICOLOGIA DA 6a REGIÃo (org.). Políticas de saúde mental e juventude nas fronteiras psi-jurídicas, São Paulo: CRP SP, 2011. p. 9-12.

${ }^{715}$ ZAPATA, 2008, p. 48-49.

${ }^{716}$ MAGLIO, 2008, p. 87-88.
} 
do Adolescente devem ser estritamente seguidas; ou seja, após 3 (três) anos de internação, ou ao se completar 21 anos, o jovem deve ser liberado ${ }^{717}$.

No mesmo sentido, o Grupo de Trabalho sobre Detenção Arbitrária, da Organização das Nações Unidas, ressaltou que esses jovens foram institucionalizados sem o devido processo legal e demonstrou preocupação devido à falta de base legal para a detenção desses indivíduos e à indeterminação do prazo de duração da internação, já que não há revisão judicial eficaz desses $\operatorname{casos}^{718}$.

Este grupo entendeu, ainda, que esse tipo de privação de liberdade é arbitrária sob os padrões internacionais de direitos humanos, particularmente se não possui base jurídica, e que a legislação utilizada não responde aos princípios e normas constitucionais e do direito internacional dos direitos humanos ${ }^{719}$.

\footnotetext{
$\overline{717}$ ORGANIZAÇÃO DAS NAÇõES UNIDAS, 2012, p. 29-30.

718 Disponível em: <http://www.onu.org.br/grupo-de-trabalho-sobre-detencao-arbitraria-declaracao-apos-aconclusao-de-sua-visita-ao-brasil-18-a-28-marco-de-2013/>, acesso em 17.08.2014.

719 Disponível em: <http://www.onu.org.br/grupo-de-trabalho-sobre-detencao-arbitraria-declaracao-apos-aconclusao-de-sua-visita-ao-brasil-18-a-28-marco-de-2013/>, acesso em 17.08.2014.
} 


\section{CAPÍTULO 5. O PRINCÍPIO DA HUMANIDADE E A PRIVAÇÃO DE LIBERDADE NO BRASIL}

5.1. O alcance da proibição de penas cruéis

A Constituição Federal prevê, como um dos direitos individuais da pessoa, em seu artigo $5^{\circ}$, inciso XLVII, alínea "e", a proibição da adoção de penas cruéis em nosso ordenamento jurídico, em razão do reconhecimento da dignidade humana como um dos fundamentos do Estado, conforme dispõe o artigo $1^{\circ}$, inciso III, da carta constitucional, e em razão da adoção do princípio da humanidade das penas.

Por penas cruéis, entende-se aquela pena que viola a dignidade da pessoa, causando sofrimento além do inerente à pena aplicada. Assim, não são apenas os tratamentos cruéis que têm essa atribuição. Este inciso abrange também outros tipos de pena, como as penas privativas de liberdade de longa duração, pois retira a esperança de liberdade da pessoa ${ }^{720}$, causando intenso sofrimento psíquico.

Essa proibição é decorrente, além do princípio da humanidade, também, do Direito Internacional dos Direitos Humanos, como, por exemplo, a Declaração dos Direitos do Homem e do Cidadão, de 1789, que estabelece, em seu artigo $9^{\circ}$, que todo rigor desnecessário na aplicação das penas deve ser severamente reprimido por lei, e o Pacto Internacional de Direitos Civis ou Políticos, de 1966, que prevê, em seu artigo $7^{\circ}$, a proibição da tortura e das penas e tratamentos cruéis, desumanos e degradantes.

Os países que ratificaram essas convenções e seus protocolos adicionais precisam incorporar essas garantias no direito interno, assegurando-os às pessoas que cumprem sanção criminal.

\footnotetext{
$\overline{{ }^{720} \text { VALOIS, 2013, p. } 159 .}$
} 
Essas garantias estão exteriorizadas também em outros dispositivos constitucionais, como as demais alíneas do inciso XLVII, do artigo $5^{\circ}$, da Constituição Federal, que preveem a proibição da adoção de penas de morte, salvo em caso de guerra declarada, nos termos do artigo 84, inciso XIX, de caráter perpétuo, de trabalhos forçados e de banimento, a proibição da tortura e dos tratamentos desumanos e degradantes e o respeito à integridade física e moral do preso, previstos, respectivamente, nos incisos III e XLIX, do artigo $5^{\circ}$, da Constituição Federal.

Tendo em vista estes direitos, que são decorrentes do princípio da humanidade, previstos na Constituição Federal e nas convenções internacionais ratificadas pelo Brasil, pode-se decompor este princípio em algumas faces, que devem ser respeitadas pelo direito brasileiro, tais como: a vedação da pena de morte, a proibição das penas e tratamentos cruéis, desumanos e degradantes, a proibição da prisão perpétua e das penas de longa duração, a proibição da pena de banimento e de trabalhos forçados. Há, ainda, a finalidade de readaptação social da pessoa privada de liberdade, que, apesar de não estar na Constituição Federal, é prevista em alguns textos internacionais e na Lei de Execução Penal.

Apesar de o texto constitucional parecer conferir esses direitos apenas às pessoas submetidas à pena privativa de liberdade, eles também devem ser aplicados às demais formas de privação de liberdade, previstas no ordenamento jurídico penal, que são a medida de segurança, na modalidade de internação, e a medida socioeducativa de internação. O caráter sancionatório e punitivo da medida de segurança e da medida socioeducativa impõe que o texto constitucional seja interpretado de maneira ampla, fazendo com que o termo "pena" passe a adquirir o conceito de "sanção penal". Assim, todas as pessoas privadas de liberdade devem ter sua dignidade respeitada, inclusive os inimputáveis, que, em razão de sua condição especial, deveriam ser contemplados com um tratamento jurídico mais favorável, de modo a ampliar seus direitos e garantias, e não restringi-los como ocorre em nossa legislação ${ }^{721}$.

$\overline{{ }^{721} \text { CARVALHO, S., } 2013, \text { p. 513, } 522 .}$ 
Esses direitos devem ser reconhecidos a todas as pessoas que cumprem essas sanções, já que a interferência estatal na liberdade da pessoa pode tornar-se ilimitada e arbitrária, afetando, outrossim, outros direitos da pessoa privada de liberdade, como sua integridade física e mental.

Em relação aos adolescentes, o artigo 227, da Constituição Federal, concedeu a eles uma proteção especial de sua dignidade, por estarem em condição peculiar de desenvolvimento, estabelecendo que a liberdade deles só será privada se respeitar os princípios da brevidade e da excepcionalidade ${ }^{722}$.

No entanto, mesmo com todos os direitos e garantias previstos constitucionalmente, a situação das pessoas privadas de liberdade no Brasil é, na realidade, violadora de seus direitos fundamentais, não tendo essas pessoas um tratamento digno, compatível com o princípio da humanidade.

\subsection{Violações ao princípio da humanidade}

Como visto nos capítulos anteriores, violações aos direitos da pessoa privada de liberdade ocorrem, pois há um descompasso entre a legislação e a aplicação desta, em razão da falta de estrutura física e humana dos locais de internação e do desrespeito dos agentes estatais com a dignidade das pessoas.

Mas, essas violações também ocorrem porque alguns dispositivos da legislação penal contrariam o princípio da humanidade, mesmo que aplicados conforme a legislação; e, também, porque, em alguns casos, apesar de a legislação ser condizente com a humanidade, os aplicadores da lei fazem interpretação que diverge deste princípio. 
5.2.1. Penas e tratamentos cruéis, desumanos e degradantes

Nesta face do princípio da humanidade, veda-se a aplicação das penas e dos tratamentos cruéis, desumanos e degradantes à pessoa privada de liberdade, que são aqueles que submetem e infligem desnecessariamente padecimento físico ou moral ao condenado, atingindo sua dignidade, além do inerente à sanção aplicada ${ }^{723}$.

Na Constituição Federal, a proibição de adoção de penas cruéis está no artigo $5^{\circ}$, inciso XLVII, alínea “e”, e a integridade física e moral dos presos é assegurada pelo inciso XLIX, desse mesmo artigo.

Como visto anteriormente, a Corte Europeia de Direitos Humanos definiu que por tratamento desumano deve-se entender aquele que causa, deliberadamente, severo sofrimento mental ou físico, de maneira injustificada; e, por tratamento degradante, aquele que humilha, de maneira grave, perante terceiros, ou aquele que leva o indivíduo a atuar contra a sua vontade ou consciência ${ }^{724}$. Já a pena ou o tratamento cruel é o que causa um ataque à dignidade humana mais intenso que o desumano.

Além disso, da proibição da pena e do tratamento cruel, desumano e degradante também resulta a proibição de adotar penas que atentam contra a integridade física ou mental do condenado, resultando em consequências permanentes.

É notório que, quando se trata das penas privativas de liberdade, elas são executadas em desacordo com esta proibição, mesmo a Lei de Execução Penal prevendo um modelo de execução das penas de prisão compatível com o princípio da humanidade.

$\mathrm{Na}$ execução da pena privativa de liberdade, os presos estão submetidos à superlotação carcerária, más condições de higiene, ficam em celas insalubres, com condições sanitárias precárias, falta de ar fresco, altas temperaturas e leitos inadequados e insuficientes. Os presos provisórios não são separados dos presos já condenados, e os do

\footnotetext{
$\overline{723}$ CERNICCHIARO, 1995 -a, p. 141-143.

${ }^{724}$ CORTE EuROPEIA DE DiREITOS HuMANOS, 1972, p. 186.
} 
regime semiaberto não são separados dos presos em regime fechado. Eles não têm assistência à saúde adequada, nem acesso à alimentação de qualidade e bem preparada. A integridade física dos detentos também não é preservada, pois sofrem torturas e maustratos dentro dos estabelecimentos penais. Assim, na realidade, o que ocorre dentro dos presídios é a retribuição pelo mal causado.

A discrepância aí existente entre a lei e sua aplicação resulta em diversas violações aos direitos do preso, constituindo-se, desta forma, a pena privativa de liberdade, um tratamento desumano, quando não cruel, como os casos de superlotação carcerária extrema e tratamento cruel dispensado pelos agentes estatais aos presos.

Essa mesma situação é verificada nos locais de cumprimento de medida de segurança, na modalidade internação, e nas unidades de internação, para cumprimento de medida socioeducativa.

Os adolescentes submetidos a medida socioeducativa de internação também estão em estabelecimentos inapropriados, sem a estrutura e condições de higiene necessárias para a manutenção da saúde e da dignidade. Eles passam, ainda, por situações degradantes, pois são submetidos a situações vexatórias e humilhantes, tais como não ter banheiros com a mínima privacidade, ter que abaixar a cabeça sempre que passa ao lado de um funcionário do estabelecimentos, ter que estar constantemente pedindo licença aos funcionários, senão é castigado, ter que realizar as refeições sob goteiras no refeitório ${ }^{725}$.

Ainda, sofrem constantemente agressões físicas e psicológicas por parte daqueles que deveriam zelar pela integridade deles ${ }^{726}$.

\footnotetext{
725 Coletivo EM DEFeSA dos direitos do(A) JOVEM PRIVAdO(A) DE LiBERdADE NA FEBEM/FCASA, 2008 , p. 24-35, 95-105.

${ }^{726}$ Dentro dos estabelecimentos prisionais, também não é garantida a segurança necessária na convivência entre os presos. Casos de violência entre os presos são constantemente relatados pela imprensa, resultando, muitas vezes, em morte. Este ano, alguns vídeos de agressões cometidas dentro de presídios, que resultaram em decapitações de alguns detentos, foram divulgados nos meios de comunicação (Disponível em: <http://www1.folha.uol.com.br/cotidiano/2014/01/1394160-presos-filmam-decapitados-em-penitenciaria-nomaranhao-veja-video.shtml>, acesso em 27.11.2014).
} 
Do mesmo modo ocorrem com os doentes e deficientes mentais em conflito com a lei, que ficam internados em estabelecimentos em piores condições e com caráter mais aflitivo do que a pena privativa de liberdade ${ }^{727}$, como, por exemplo, ficam em celas inabitáveis, como no caso relatado, em que pessoas que cumpriam medida de segurança ficavam em celas com dejetos espalhados pelo chão e paredes ${ }^{728}$.

A disciplina severa constatada em algumas unidades de internação de adolescentes e de cumprimento da pena privativa de liberdade também é uma forma de tratamento que atenta contra o princípio da humanidade, pois, se for demasiadamente repressiva, pode deixar sequelas psicológicas no indivíduo. Como visto, alguns estabelecimentos em São Paulo contam com esse sistema mais duro de disciplina, onde os presos são rigorosamente monitorados nos deslocamentos que fazem dentro da unidade, e, em algumas situações são algemados nesses deslocamentos ${ }^{729}$. Foram encontrados, também, no Espírito Santo, adolescentes internados em estabelecimento que tinham características de segurança máxima $^{730}$.

A segurança das unidades de internação, seja para o cumprimento de pena privativa de liberdade, seja para o cumprimento da medida socioeducativa de internação, deve ser a necessária e adequada para a manutenção da segurança e da organização interna do estabelecimento, como previsto nos artigos 27 e 28, das Regras Mínimas para o Tratamento dos Reclusos, e 125, do Estatuto da Criança e do Adolescente.

Como também se caracteriza tratamento desumano aquele que deixa sequelas permanentes no indivíduo submetido a uma sanção penal, o tratamento oferecido na medida de segurança pode desrespeitar o princípio ora tratado, pois, dependendo do tratamento aplicado, pode resultar na alteração psíquica da pessoa internada, como nos casos da aplicação do eletrochoque e das psicocirurgias ${ }^{731}$.

\footnotetext{
$\overline{727}$ FrAGOSO, 2004, p. 496; CINTRA JR., 2003, p. 158-161.

${ }^{728}$ BRASIL. Câmara dos Deputados, 2000, p. 9.

${ }^{729}$ BRASIL. MINISTÉRIO DA JUSTIÇA, 2011, p. 21-22 e 27-28.

${ }^{730}$ ORGANIZAÇÃO DAS NAÇÕES UNIDAS, 2012, p. 24-28.

${ }^{731}$ BRASIL. Câmara dos Deputados, op. cit., p. 6.
} 
Estas têm por objetivo alterar o funcionamento psíquico da pessoa, para que ela não tenha mais determinadas características, como tendência a reações violentas, o que deixa uma marca permanente nela, podendo resultar, ainda, em graves consequências, como o comprometimento mental e perda da autodeterminação ${ }^{732}$. Ressalta-se que o tratamento disponível para as pessoas submetidas à medida de segurança não condiz com os princípios trazidos pela Lei Federal nº 10.216/2001, que tratou da reforma psiquiátrica.

Efeito parecido pode ocorrer com o adolescente submetido à medida socioeducativa de internação, pois a indeterminação do tempo de duração desta medida pode importar, para o adolescente, na mudança de sua personalidade, haja vista que os critérios de reavaliação não são bem definidos e fica ao arbítrio do magistrado a desinternação do adolescente antes do prazo máximo de 3 (três) anos de duração da medida ${ }^{733}$. Ressalta-se que o Estado não pode destruir o condenado ou sua personalidade, seja física, psíquica ou socialmente, pois deve respeitar a pessoa em todos os seus aspectos ${ }^{734}$.

O Estado não possui legitimidade de modificar internamente ninguém. A intervenção estatal tem que ser o menos violante simbólica e materialmente e não pode, em nome do bem, promover a devastação da subjetividade ${ }^{735}$.

Estes são alguns casos em que se infringe o princípio da humidade, submetendo pessoas privadas de liberdade a tratamentos cruéis, desumanos e degradantes, em razão do descumprimento das normas existentes que regulam como deve ser a privação de liberdade dessas pessoas, dispondo sobre o tratamento que deve ser dispensado aos presos, a estrutura física dos estabelecimentos de internação e tratamento médico que deve ser oferecido aos doentes e deficientes mentais. Mas, esse tipo de tratamento, constitucionalmente proibido, também pode decorrer da própria lei, como é o caso da Lei Federal $n^{\circ} 10.792 / 2003$, que instituiu o regime disciplinar diferenciado.

No caso do regime disciplinar diferenciado, o tratamento ao qual o preso é submetido é excessivamente aflitivo, pois ele deve ficar dentro da cela, isolado, por 22

\footnotetext{
$\overline{732}$ JACOBINA, 2008, p. 95-99.

${ }^{733}$ ZAPATA, 2008, p. 44-45.

734 GUZMÁN DÁLBORA, 2008, p. 292.

${ }^{735}$ RosA, 2006, p. 19-21.
} 
horas diárias, por um período de até um sexto da pena, não tendo oportunidade de convivência com os demais presos e tendo as possibilidades de visitas de familiares e amigos diminuídas. O sofrimento causado por este regime é uma "sobrepena" cruel $^{736}$, pois é superior àquele inerente à pena privativa de liberdade.

Assim, nessa modalidade de cumprimento de pena privativa de liberdade, mesmo se cumprida conforme a lei citada acima, o sofrimento causado à pessoa desrespeita a dignidade dela, e, portanto, é desumana, não devendo ser aceita diante do princípio da humanidade e do artigo 5, inciso XLVII, alínea “e”, da Constituição Federal.

\subsubsection{Penas perpétuas e de longa duração}

Esta outra face do princípio da humanidade das penas diz respeito à proibição de penas perpétuas, prevista no artigo 5o, inciso XLVII, alínea "b", da Constituição Federal. Contudo, conforme construção do Direito Internacional dos Direitos Humanos, devem, também, ser abrangidas por esta proibição as penas privativas de liberdade de longa duração, previsão encontrada no artigo 75, do Código Penal, que dispõe que as penas privativas de liberdade não podem ser superiores a 30 anos.

A pena perpétua retira da sanção a racionalidade e proporcionalidade que ela deve ter, e elimina do indivíduo uma expectativa concreta de liberação, pois o segrega permanentemente. Já as penas de longa duração podem acabar se equiparando às penas perpétuas $^{737}$, pois são destituídas de objetivo de reintegração social da pessoa, além de resultarem em efeitos psicológicos e sociais negativos, retirando, também, do detento, a esperança de liberdade ${ }^{738}$, e, assim, desestimulando-o a preparar-se para recomeçar a vida em liberdade ${ }^{739}$.

\footnotetext{
${ }_{736}$ MOURA, 2004, p. 63-64.

${ }^{737}$ CERNICCHIARO, 1995-a, p. 130-132.

${ }^{738}$ DE LA CUESTA ARZAMENDI, 2009, p. 216-220.

${ }^{739}$ SANTORO FILHO, 2003, p. 46-50.
} 
No ordenamento jurídico-penal, a pena privativa de liberdade, como citado acima, é limitada a 30 anos de duração, e a medida socioeducativa de internação é limitada a 3 (três) anos, conforme prevê o artigo 121, parágrafo $3^{\circ}$, do Estatuto da Criança e do Adolescentes.

No entanto, há dois casos na legislação que desrespeitam tal proibição, por não limitarem no tempo a sanção penal, permitindo, desta forma, uma pena perpétua.

A primeira delas é a medida de segurança, na modalidade de internação, prevista o artigo 97, parágrafo $1^{\circ}$, do Código Penal, que prevê um prazo mínimo para o cumprimento da medida, mas não prevê um prazo máximo, dispondo que este será indeterminado, devendo a medida perdurar enquanto ainda for constatada a periculosidade do agente.

Este dispositivo, ao se omitir quanto a um limite temporal máximo, permite que uma pessoa seja perpetuamente internada em decorrência de uma medida de segurança, caso a periculosidade esteja associada a alguma enfermidade da qual não é possível obter a cura.

Hoje, dado o reconhecimento do caráter penal desta medida, a jurisprudência tem se posicionado no sentido de que esta privação de liberdade não pode ultrapassar o período de 30 anos, mesmo período que a pena privativa de liberdade ${ }^{740}$. Este entendimento não é unânime, pois também se entende que a medida deve perdurar enquanto for constatada a periculosidade e que o limite máximo deveria ser o cominado abstratamente para a infração praticada pela pessoa submetida a esta medida ${ }^{741}$. Este limite tem sido utilizado pelo Poder Executivo para editar indultos para as pessoas nesta situação, que extingue a punibilidade daqueles que já suportaram privação de liberdade por tempo igual ou superior à pena abstratamente cominada à infração praticada ${ }^{742}$.

\footnotetext{
$\overline{740}$ Entre outros, adota este entendimento, SILVA; GoMES, 2009, p. 68-69. Necessário ressaltar que, neste caso, após o período de 30 anos, a pessoa pode ser submetida a nova internação pelo juízo cível, caso se entenda necessário.

${ }^{741}$ Entre outros, adota este entendimento, ZAFFARONI; PIERANGELI, 2009, p. 733-734.

${ }^{742}$ Por exemplo, o artigo $1^{\circ}$, inciso XII, do Decreto $\mathrm{n}^{\circ} 8.172 / 2013$.
} 
A possibilidade de manutenção de uma privação de liberdade perpetuamente, em razão da previsão legal, omissa em relação à duração máxima da sanção, também é percebida quando se trata da privação da liberdade de jovens na Unidade Experimental de Saúde, em São Paulo.

Como visto, este estabelecimento destina-se, de modo geral, aos egressos da Fundação Casa, com diagnóstico de distúrbio de personalidade e com alta periculosidade, que necessitam de contenção para realização de tratamento médico.

Assim como ocorre com a medida de segurança, esse modelo de tratamento psiquiátrico não condiz com a reforma psiquiátrica e permite uma intervenção estatal ilimitada do direito à liberdade do indivíduo, pois, com o pretexto de tratamento e objetivo de cessação da periculosidade, a pessoa não tem qualquer perspectiva de retorno à sociedade $^{743}$.

No caso da Unidade Experimental de Saúde, além da discussão acerca da legalidade da medida, pois se trata de sanção sem uma infração correspondente, o Decreto Estadual $n^{\circ}$ 53.427/2008/SP não ofereceu qualquer parâmetro de liberação da pessoa ali internada, podendo, desta forma, esta sanção, ter o caráter perpétuo.

Necessário salientar que, em decorrência do viés punitivo desta medida e tendo em vista a intervenção estatal na liberdade do indivíduo, os jovens internados neste estabelecimento devem ter todos os direitos e garantias penais que tem qualquer pessoa privada de liberdade em razão de uma sanção penal, inclusive o direito de não ser submetido a uma prisão perpétua ou de longa duração.

Assim, percebe-se que nestes dois casos a lei abre a possibilidade para uma privação de liberdade perpétua, tendo a jurisprudência e o Poder Executivo se manifestado, no sentido de estabelecer um limite para essa internação, por enquanto, apenas no caso da medida de segurança.

$\overline{{ }^{743} \text { MaGLIO, 2008, p. }}$ 87-88. 
Em relação à pena privativa de liberdade, o Código Penal estabelece, como já citado acima, que o limite de cumprimento da pena é de 30 anos, mesmo que a pessoa seja condenada a pena superior a isso, devendo a pena ser cumprida de modo progressivo, de acordo com o artigo 33, parágrafo $2^{\circ}$, do Código Penal. No entanto, apesar dessas duas previsões, é possível a aplicação de uma pena de longa duração.

A Corte Europeia de Direitos Humanos entendeu que a pena de prisão perpétua é admissível, desde que haja a possibilidade de revisão da pena, e concessão de liberdade condicional, após o cumprimento de 25 anos de privação de liberdade. Já o enunciado 715 , da Súmula do Supremo Tribunal Federal, estabelece que o cálculo para a concessão do livramento condicional, previsto no artigo 83, do Código Penal, deve se dar pela pena total aplicada à pessoa condenada, e não pela pena unificada. Assim, por exemplo, uma pessoa condenada por crimes de tráfico de drogas, da Lei Federal no 11.343/2006, a 45 anos de reclusão, ou uma pessoa que seja reincidente específica em alguma ação desta lei, conforme artigo 44, parágrafo único, desta lei, não conseguirá obter livramento condicional antes de sua liberdade, após o cumprimento de 30 anos de prisão.

Ou seja, uma pessoa condenada na Europa à prisão perpétua poderá conseguir retornar ao convívio social antes de uma pessoa, como no caso citado acima, condenada à pena privativa de liberdade no Brasil. Isto porque o entendimento do Supremo Tribunal Federal pode criar uma pena perpétua de fato ${ }^{744}$, ou pena de longa duração, proibida em razão da adoção do princípio da humanidade das penas. Saliente-se que, da mesma forma que não será permitido o livramento condicional, também não será possível a progressão de regime, cujo cálculo para a concessão se dá, também, sobre a pena total. Assim, o condenado cumprirá a pena integralmente em regime fechado, durante 30 anos, prejudicando, ainda, a finalidade de readaptação social da pena ${ }^{745}$.

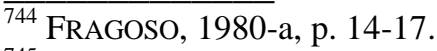

${ }^{745}$ No projeto do novo Código Penal (Projeto de Lei do Senado no 236/2012), essa situação se agrava, pois pretende extinguir o livramento condicional e tornar a progressão de regime mais difícil, sendo necessário o cumprimento de um quarto da pena, se não reincidente em crime doloso, ou um terço da pena, se reincidente em crime doloso ou se o crime for cometido com violência ou grave ameaça ( $\mathrm{O}$ documento pode ser acessado em: <http://www.senado.gov.br/atividade/materia/getPDF.asp?t=143412\&tp=1>, acesso em 27.10.2014). Necessário lembrar que as pessoas condenadas por crimes hediondos já estão sujeitas a critérios objetivos mais rigorosos para a progressão da pena, sendo que elas já tiveram maior quantidade de pena em razão do crime praticado. Retira-se da pena, assim, sua racionalidade e seu caráter progressista.
} 
Neste caso, a pena de longa duração também é vedada, pois é excessivamente aflitiva. Retira do condenado o vislumbre de ver-se em liberdade e retira da pena qualquer finalidade de prevenção especial positiva, tornando-a meramente expiatória e tratando o indivíduo apenas como um objeto da intervenção punitiva estatal. Necessário ressaltar que esses limites devem ser revistos de tempos em tempos, em razão do reconhecimento de que quanto maior o tempo de aprisionamento, maiores serão os efeitos causados pela dessocialização.

5.2.3. A finalidade da privação de liberdade

A privação de liberdade deve ter por finalidade a readaptação social do condenado, conforme artigos 10.3, do Pacto Internacional de Direitos Civis e Políticos, e 5.6, da Convenção Americana de Direitos Humanos; ou seja, deve ter uma orientação ressocializadora. A mesma previsão se encontra no artigo $1^{\circ}$, da Lei de Execução Penal, que diz que a pena deve propiciar condições para a harmônica reintegração social do condenado e do internado.

Para tanto, a pena que importe em privação de liberdade deve reduzir o seu conteúdo estigmatizador e deve oferecer oportunidades para a superação da marginalização ${ }^{746}$, preparando, aos poucos, o preso para a vida coletiva e às suas exigências $^{747}$, como, por exemplo, utilizando o tempo da privação de liberdade para oferecer educação, profissionalização e trabalho, de modo a permitir que a pessoa privada de liberdade tenha condições de levar uma vida licitamente após recuperar a liberdade. Contudo, não pode a pena coagir o condenado a adotar determinados valores, nem manipular os valores do sujeito. Deve ser a apresentação de uma oferta de alternativas ao sujeito, à qual ele pode $\operatorname{aderir}^{748}$.

Deve, também, ser trabalhada a relação entre o indivíduo e a sociedade, de modo a superar qualquer histórico de exclusão social e escolar da qual a pessoa foi vítima, além de

\footnotetext{
$\overline{746}$ DE LA CUESTA ARZAMENDI, 2009, p. 222-223.

${ }^{747}$ BETTIOL, 1964, p. 9.

${ }^{748}$ MARTOS NúÑEZ, 1991, p. 289-296.
} 
possibilitar uma maior conscientização sobre as consequências do crime ${ }^{749}$. Medidas políticas também devem ser tomadas na sociedade, para que, quando solto, o indivíduo tenha as condições necessárias para retomar sua vida em liberdade ${ }^{750}$.

A adoção de um sistema progressivo de cumprimento da pena privativa de liberdade também é importante, pois promove um processo gradual de reintegração social, sendo que durante o cumprimento de todas as etapas da pena, o detento deve ser estimulado a exercer os direitos não atingidos pela sentença criminal, como forma de atenuar os efeitos de seu afastamento social ${ }^{751}$.

Como visto acima, o entendimento do Supremo Tribunal Federal, esposado no enunciado 715, de sua súmula, além de permitir a aplicação de uma pena de longa duração, também pode retirar da imposição de uma privação de liberdade sua orientação ressocializadora, tendo em vista que é possível o cumprimento de uma pena, até o limite de 30 anos, sem que o preso progrida de regime ou obtenha livramento condicional, pois o cálculo para a progressão deve ser feito sobre a pena total e não sobre a pena unificada.

Assim, além de cumprir a pena em regime integralmente fechado, sem possibilidade de progressão de regime ou de livramento condicional, sem passar por etapas de progressão, o indivíduo sente-se desestimulado a participar de atividades que têm por objetivo oferecer novas oportunidades quando liberto, como, por exemplo, estudo e trabalho, pois, quando existente, qualquer perspectiva de liberdade é muito distante.

O cumprimento da pena integralmente em regime fechado dessocializa o indivíduo, atribui um caráter meramente retributivo à pena e submete a pessoa a um prolongado sofrimento, que traz consequências psíquicas e emocionais ${ }^{752}$.

\footnotetext{
$\overline{749}$ SÁ, 2001, p. 170-177.

${ }^{750}$ BETTIOL, 1964, p. 9.

${ }^{751}$ FRANCO; LIRA; FELIX, 2011, p. 81-83.

752 Blanco LOZANO; TinOCO PASTRANA, 2009, p. 74.
} 
Ademais, quando liberto, após o cumprimento de uma pena de longa duração, a pessoa terá dificuldades de readaptação social, tendo em vista as mudanças sociais ocorridas, que a pessoa privada de liberdade pode nem tomar conhecimento.

Em alguns casos, apesar de a lei prever condições para a reintegração social do preso, a execução da pena não atinge este objetivo, em razão da ineficiência dos programas oferecidos dentro dos locais de cumprimento da privação de liberdade.

É o caso, por exemplo, da educação e profissionalização que devem ser oferecidas aos adolescentes que cumprem medidas socioeducativas de internação. A educação é oferecida em módulos seriados, e o educando não tem as mesmas oportunidades de aprendizado que tem o aluno fora do estabelecimento de internação, pois, a dinâmica da aula é diferente, onde, às vezes, o aluno sequer pode fazer perguntas ao professor, e os professores podem tratá-los de forma a reforçar o estigma e a exclusão social que eles já sofrem $^{753}$. Soma-se a isso a falta de acesso a materiais de estudo e pesquisa.

A profissionalização disponível aos adolescentes internados não oferece efetivas e verdadeiras oportunidades de emprego para eles, pois os programas oferecem cursos de baixa qualidade, baixa remuneração no mercado de trabalho e métodos de aprendizados que não despertam na pessoa o interesse pela profissão ${ }^{754}$.

As pessoas que cumprem penas privativas de liberdade também têm o mesmo problema em relação ao trabalho. Apesar de ser uma maneira de manter-se numa ocupação útil e rendosa, cujo aprendizado e experiência podem proporcionar oportunidades de emprego quando liberto ${ }^{755}$, o trabalho oferecido nas prisões não alcança esses objetivos. Primeiramente, não há vagas para todos os presos. Ainda, os salários oferecidos não são justos e não atendem ao mínimo previsto em lei, aproveitando-se algumas empresas dessa mão-de-obra barata; o trabalho oferecido dentro das prisões não leva em consideração as oportunidades oferecidas pelo mercado de trabalho, não qualifica profissionalmente a

\footnotetext{
${ }^{753}$ Coletivo em Defesa dos direitos do(A) Jovem PRivado(A) DE Liberdade na FEbem/FCASA, 2008, p. 24-35.

${ }^{754}$ Ibid., p. 95-105.

${ }^{755}$ CATÃO; SÜSSEKIND, 1980, p. 104-106.
} 
pessoa; e algumas ocupações são taxadas como "trabalho de preso", como, por exemplo, a costura de bolas, onde a pessoa aprenderá um ofício, o qual não encontrará fora das prisões.

Isso acaba desestimulando os presos a participarem dessas atividades, além de que, quando soltos, não conseguem uma colocação profissional, pois não têm qualificação nem experiência, diante dos serviços desqualificados realizados. Ainda, a organização do trabalho dentro da prisão é diversa da existente no mercado de trabalho ${ }^{756}$.

Assim, em razão da forma como esses programas são executados, apesar do parâmetro previsto em lei, eles não alcançam seus objetivos para auxiliar na reintegração social da pessoa privada de liberdade, pois, muitas vezes, não têm utilidade quando fora da prisão.

Necessário ressaltar que todo o tratamento dispensado a pessoas privadas de liberdade, em especial aos que cumprem pena privativa de liberdade e medida socioeducativa, como relatado acima, que é cruel, desumano e degradante, também atrapalha qualquer orientação ressocializadora que a pena almeja ter, pois isso só cria um sentimento antissocial no preso, que não quer fazer parte da sociedade e a ataca, reforçando a exclusão social e a marginalização; e a aceitação deste tratamento pela sociedade demonstra o fechamento que ela faz em relação ao preso.

O cenário de abandono dos cárceres brasileiros faz com que este também seja um fator criminógeno, tornando a pessoa ali internada mais sujeita à violência, além de favorecer o contato com criminosos violentos, facções criminosas, e relações corruptas entre presos e funcionários. Cria-se, ainda, uma subcultura criminal ${ }^{757}$, com base em regras e valores próprios, a qual o preso adere ${ }^{758}$.

\footnotetext{
$\overline{756}$ MADEIRA, 2003, p. 98-111.

${ }^{757}$ Ibid., p. 98-104.

${ }^{758}$ RIBEIRO, 2008, p. 49.
} 
A previsão do regime disciplinar diferenciado no ordenamento jurídico também abdicou do fim ressocializador da pena privativa de liberdade, pois esta medida tem por escopo a segregação do condenado. Mesmo que durante o cumprimento da pena em regime disciplinar diferenciado o preso cumpra os requisitos objetivos para a progressão de regime, ele ficará segregado no estabelecimento prisional, não podendo passar para regime mais brando, devendo ficar isolado por 22 horas diárias e com menor contato com o mundo externo.

O mesmo ocorre com a medida de segurança, pois ela não oferece às pessoas com enfermidade mental um tratamento compatível com sua enfermidade, de modo a cessar a periculosidade e possibilitar o retorno ao convívio social da pessoa internada.

As pessoas que cumprem medidas de segurança não têm um tratamento individualizado $^{759}$ e os locais de internação não têm estrutura física e humana para oferecer o tratamento adequado a cada um. O tratamento a que eles estão submetidos são, ainda, clinicamente questionáveis $^{760}$. No fim, as doenças acabam de cronificando dentro dos manicômios.

Necessário lembrar que, se o tratamento adequado à pessoa que praticou infração à qual o Código Penal comina pena de reclusão for o ambulatorial, esta pessoa não terá possibilidade de realizar este tratamento, pois a lei impõe um tratamento de internação, deixando a pessoa, perigosa, internada perpetuamente, sem chances de retorno ao convívio social e, por isso, sem a elaboração de um programa que possibilite esse retorno ${ }^{761}$.

O internamento prolongado promove, ainda, um hospitalismo e dependência institucional, aliada à marginalização e exclusão, que poderiam ser evitados e que o internado dificilmente irá superar ${ }^{762}$. A falta de um tratamento adequado, com a consequente ausência de progresso no tratamento do enfermo mental, desestimula,

\footnotetext{
$\overline{759}$ DOTTI, 2001, p. 310.

${ }^{760}$ CIA, 2011, p. 17-24.

${ }^{761}$ Destaca-se que, no caso das medidas de segurança, já começou a ser adotada a desinternação progressiva para que os enfermos mentais também tenham a oportunidade de recuperar a liberdade aos poucos, por meio de etapas.

${ }^{762}$ PINTO; ROFRANO, 2009, p. 582-585.
} 
também, os familiares a acompanhar o inimputável, afastando-o de sua família e da sociedade ${ }^{763}$.

Percebe-se, assim, que a finalidade de readaptação social da pessoa privada de liberdade, que toda pena deve ter, não é atingida em diversas ocasiões por vários motivos. Como relatado acima, a interpretação judicial sobre um dispositivo da legislação pode dificultar o retorno de uma pessoa à sociedade, a discrepância existente entre a lei e a aplicação da pena pode retirar da pena a eficácia quando ao alcance da prevenção especial positiva, e a própria lei pode prever dispositivos que impedem que as penas cumpram esse objetivo.

Além disso, as penas trazem algumas consequências que são inerentes a elas, que faz com que a ideia de reintegração social seja incompatível com a privação de liberdade $^{764}$, ainda mais tendo em vista que o ambiente nos estabelecimentos de privação de liberdade é diferente dos que a pessoa encontrará na sociedade, já que o primeiro é um espaço de anormalidade e violência ${ }^{765}$.

Os estabelecimentos de privação de liberdade são instituições totais que acabam por despersonalizar a pessoa, fazendo-a adotar as regras e costumes do ambiente na qual está inserida, adquirindo hábitos e um novo modo de ser carcerário, retirando, ainda, da pessoa sua autonomia.

As pessoas submetidas à pena privativa de liberdade e à medida socioeducativa de internação acabam submetidas aos efeitos da prisionização, onde adquirem a identidade da pessoa criminosa: ganham novo modo de falar, de gesticular, passam a fazer parte de uma hierarquia dentro dos estabelecimentos. Esses efeitos são piores quando maior for o tempo de internamento.

\footnotetext{
$\overline{763}$ GONÇALVES, 2006, p. 2-4.

${ }^{764}$ KARAM, 2008, p. 153-154; CERNICCHIARO, 2003, p. 290-292.

${ }^{765}$ FERREIRA; CUTIÑO RAYA, 2004, p. 259-262.
} 
Com os problemas inerentes ao cumprimento de uma pena privativa de liberdade, fica a pessoa condenada, ainda, estigmatizada. Ao retornar para o convívio social, suas chances de obter um emprego, por exemplo, ficam diminuídas em razão do receio causado pela passagem da pessoa pelo sistema prisional, ainda que a pena não tenha se dado por causa de um crime violento.

Isso impede uma readaptação social da pessoa privada de liberdade, pois, ao ser liberta, a pessoa está estigmatizada e, às vezes, dentro de relacionamentos criminosos, que estimulam a prática de crimes e marginalização social. Ainda, o preso precisa se esforçar para superar as barreiras psicológicas, físicas e sociais do encarceramento, e ter de se ver culpado quanto a um eventual fracasso da ressocialização, que é imposto a ele, não à pena $^{766}$.

Ao sair da prisão, a pessoa deveria ter todas as condições de retomar a sua vida, haja vista o término de cumprimento da pena.

\subsubsection{Do respeito à dignidade humana}

Além das violações citadas acima, há algumas que desrespeitam diretamente a dignidade da pessoa, fundamento do Estado, conforme o artigo $1^{\circ}$, inciso III, da Constituição Federal.

$\mathrm{Na}$ imposição de uma pena criminal, o Estado não pode ignorar a dignidade da pessoa, pois é inerente a ela. Assim, devem ser reconhecidos às pessoas privadas de liberdade seus direitos fundamentais, devendo o Estado possibilitar o exercício de todos os direitos que não tenham sido restritos na sentença condenatória, ou que sejam incompatíveis com a privação de liberdade. As pessoas devem, também, ser tratadas com valor em si mesmas, ou seja, não podem ser meros objetos da intervenção estatal ${ }^{767}$.

No entanto, como já citado acima, foram adotadas nos últimos anos duas medidas

\footnotetext{
$\overline{7^{766} \text { VALOIS, 2013, p. }} .87-88$.

${ }^{767}$ DE LA CUESTA ARZAMENDI, 2009, p. 210-211.
} 
penais - simbólicas - que flexibilizaram os princípios penais em razão de uma suposta maior segurança pública, tratando as pessoas submetidas a estas medidas como meros instrumentos da intervenção punitiva estatal, e não mais como sujeitos de direitos, detentores de direitos fundamentais. Trata-se do regime disciplinar diferenciado e da Unidade Experimental de Saúde, esta adotada apenas no estado de São Paulo. Estas medidas têm por semelhança seus fundamentos, que é a periculosidade que a pessoa submetida a elas apresenta, e não mais o ato por elas praticado, além de serem medidas elaboradas para atender a um clamor público de mais segurança. Isso levou a um direito menos compatível e harmônico com os marcos constitucionais, pois viola os direitos individuais e fundamentais do preso $^{768}$, e tem ênfase na segregação e exclusão da pessoa que cumpre uma dessas medidas ${ }^{769}$.

A Unidade Experimental de Saúde ainda vai além, pois é uma medida pré-delitual, imposta sem uma infração correspondente que a fundamente. Tendo como único objetivo retirar pessoas com alta chance de reincidência e periculosidade da sociedade, esta medida inocuiza o jovem, retirando dele todos os direitos e garantias que todas as pessoas submetidas a uma sanção penal devem ter ${ }^{770}$.

São medidas herdadas do positivismo, onde há intervenção estatal, através de seu poder punitivo, em razão da periculosidade do agente ${ }^{771}$.

Ademais, ainda em relação aos adolescentes em conflito com a lei, a persistência dos magistrados e dos tribunais em desrespeitar a doutrina da proteção integral às crianças e aos adolescentes tem deixado de lado a excepcionalidade da privação de liberdade imposta aos adolescentes que cometem atos infracionais, impondo-a em casos de infrações leves e em casos não permitidos pela lei.

Além de retirar da medida socioeducativa seu caráter racional, a dignidade dos adolescentes é prejudicada em razão da proteção especial dada pela Constituição Federal,

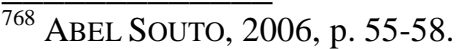

${ }^{769}$ CARVALHO; Freire, 2005, p. 7-10.

${ }^{770}$ SANTORO FILHO, 2013

${ }^{771}$ GRACIA MARTÍN, 2008, p. 978.
} 
que estabeleceu que a liberdade do adolescente só poderá ser privada se obedecidos os princípios da excepcionalidade e da brevidade.

Todos os problemas constatados nos estabelecimentos de internação também degradam o indivíduo, causando problemas drásticos, psicológicos e sociais, para o condenado, inclusive em sua relação com a sociedade ${ }^{772}$. O recluso passa por um processo de modificação a respeito das concepções que tem de si mesmo e passa a ser tratado como um objeto, que não é mais responsável por si, perdendo a autonomia e a liberdade de ação $^{773}$.

5.3. Do respeito ao princípio da humanidade no Brasil

Conforme exposto, muitas são as violações ao princípio da humanidade e à proibição constitucional de adoção de penas cruéis.

Dessas violações, têm-se aquelas que com esforço político e social podem ser corrigidas, como o caso dos tratamentos cruéis dispensados às pessoas privadas de liberdade, os programas socioeducativos de educação e profissionalização, o trabalho dentro das prisões, o tratamento oferecido para os que cumprem medidas de segurança, a falta de estrutura física, material e humana, bem como o funcionamento do cárcere como um fator criminógeno.

Para evitar que haja tal descompasso entre a lei e sua aplicação, é necessária a adoção de medidas que efetivem as regras da execução penal. Por exemplo, deve haver maior esforço de diversas autoridades em realizar visitas a estabelecimentos destinados ao cumprimento da pena privativa de liberdade, para acompanhar a execução dessas penas e tomar as medidas necessárias para punir os servidores responsáveis pelas violações dos direitos das pessoas presas, como determina o Protocolo Facultativo da Convenção contra a Tortura e Outros Tratamentos e Penas Cruéis, Desumanas ou Degradantes, adotado pela Assembleia Geral das Nações Unidas, além de maiores investimentos na estrutura física e

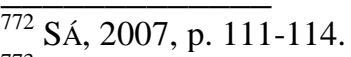

${ }^{773}$ RIBEIRO, 2008, p. 40-45.
} 
humana dos locais de internação. É necessária, também, uma maior abertura da sociedade para o cárcere e do cárcere para a sociedade, de modo a auxiliar no respeito aos direitos individuais do preso.

A mudança de entendimento dos tribunais, para facilitar o livramento condicional e progressão de regime também tornaria a pena mais humana, tendo em vista que esta não se tornaria perpétua de fato e daria às pessoas uma esperança de liberdade, além de as pessoas ficarem menos tempo expostas aos efeitos perversos do cárcere. A internação de adolescentes respeitando o princípio da excepcionalidade e os requisitos legais ficaria de acordo com a proteção especial que a Constituição Federal deu à dignidade deles.

Mas, há casos em que a violação a este princípio está na própria lei, independentemente da forma como for a execução da pena, sendo necessário, portanto, alterações legislativas para que se alcance o respeito à pessoa na execução de uma pena privativa de liberdade.

É o caso da medida de segurança, que deveria possibilitar um tratamento de acordo com a Lei Federal n 10.216/2001; ou seja, de desinstitucionalização. Ainda, a internação, nesses casos, não deveria ser obrigatória de acordo com o tipo de crime praticado, e sim de acordo com o tratamento necessário à pessoa. Deveria haver, também, um limite temporal para essa medida para evitar a possibilidade de pena perpétua, sem que a desinternação do sistema penal importasse a internação pelo juízo cível, pela perpetuidade.

A Unidade Experimental de Saúde e o regime disciplinar diferenciado são penas em que a própria lei que os criou desrespeita a proibição de adoção de penas cruéis, pois causam intenso sofrimento físico e psicológico, em razão das condições de privação de liberdade, e, no primeiro caso, o jovem não ter qualquer vislumbre de liberdade. Essas medidas deveriam ser extintas do ordenamento jurídico, por serem desumanas, assim como 
já recomendou a Organização das Nações Unidas no caso da Unidade Experimental de Saúde ${ }^{774}$.

Essas medidas de pura defesa social, cujo objetivo é a inocuização dos presos, afetam os direitos das pessoas a elas submetidas, inclusive a humanidade que as sanções devem ter $^{775}$.

Ainda em relação aos adolescentes em conflito com a lei, devem ser tomadas medidas para estabelecer critérios bem definidos a respeito do tempo de duração da prisão, para que não fique ao arbítrio da equipe técnica ou do magistrado a desinternação, e para que não importe em intervenção na subjetividade do adolescente. Em relação à legalidade, a previsão das faltas disciplinares aplicadas às pessoas submetidas à pena privativa de liberdade deveria de fato respeitar este princípio, de modo a evitar arbítrios.

No que se refere às condições de reintegração social que a privação de liberdade deve propiciar, é necessário não perder de vista que toda privação de liberdade é, em si, um mal, tendo em vista os problemas inerentes a ela e por afastar o preso do meio social ${ }^{776}$. Mas, enquanto não se adota outra medida que garanta uma convivência social suportável $^{777}$, devem-se deixar estas penas o mais humana possível. Assim, devem ser amenizados os efeitos resultantes das características inerentes à privação de liberdade, tais como a despersonalização, prisionização e estigmatização.

Para isso, a privação de liberdade deve ser imposta somente em caráter residual ${ }^{778}$, apenas para aqueles que cometeram crimes graves, de grande danosidade, e evitando, ainda, o encarceramento demasiadamente longo ${ }^{779}$.

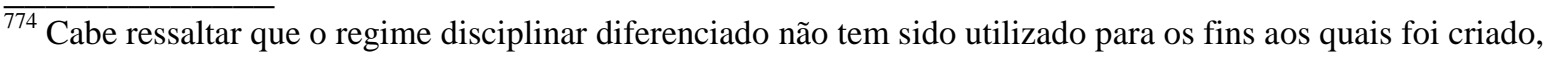
tendo em vista que os líderes do PCC estão na penitenciária de Presidente Venceslau e não na de Presidente Bernardes, unidade destinada ao regime disciplinar diferenciado. Conforme relatório produzido pelo ONU, esta tem se destinado para presos que cumprem falta grave em decorrência de agressão a funcionários da administração penitenciária (BRASIL. MINISTÉRIO DA JUSTIÇA, 2011, p. 28).

775 GRACIA MARTÍN, 2008, p. 996-997.

${ }^{776}$ VALOIS, 2013, p. 75-80, 87-88.

777 ABEL SOUTO, 2006, p. 55-58.

${ }^{778}$ RivaCOBA Y RIVACOBA, 1996, p. 36.
} 
Devem ser amenizados os efeitos deletérios da prisionalização e deve haver preocupações com o tratamento do preso como um sujeito de direito, pois uma infraestrutura carcerária que impeça a dessocialização do condenado à pena privativa de liberdade também é um dos corolários do princípio da humanidade ${ }^{780}$. Sempre que houver demanda do preso, o Estado deve oferecer as condições necessárias para que ele estude, se profissionalize, trabalhe, tenha acesso a tratamentos médicos e psicológicos durante o tempo em que estiver privado de liberdade. Além disso, devem ser adotadas as medidas necessárias para que a pena não se constitua um estigma e para que o preso possa retomar a sua vida quando liberto, como, por exemplo, retirando os nomes dos réus em processos constantes na Internet, conforme previsão do artigo 202, da Lei de Execução Penal ${ }^{781}$.

Outro modelo de estabelecimentos penais pode ser adotado, diante de um número reduzido de presos $^{782}$, como os centros de ressocialização existentes em São Paulo, onde o tratamento dispensado aos presos é diferente dos estabelecimentos comuns, com tratamento e funcionários mais humanos e com maior abertura à participação social.

Algum efeito dessocializador é inerente à privação de liberdade da mesma forma lhe é inerente uma carga aflitiva, já que a responsabilização do delinquente não pode ser obtida sem dano e sem dor ${ }^{783}$. Como ainda não há uma alternativa à privação de liberdade, devem-se aplicar soluções para a pena ficar mais humana, diminuindo o estigma que marca os egressos. O fim de reinserção social está previsto nos artigos 10.3, do Pacto Internacional de Direitos Civis e Políticos, 5.6, da Convenção Americana de Direitos Humanos, e no artigo $1^{\circ}$, da Lei de Execução Penal, que estabelece que a pena deve propiciar as condições para a harmônica integração social do internado. Desta forma, a pena privativa de liberdade deve respeitar esses dispositivos citados e se alinhar ao respeito à dignidade humana, prevista na Constituição Federal, deixando à prisão apenas os efeitos inerentes a ela e evitando os que podem ser dela banidos.

\footnotetext{
${ }^{779}$ FRAGOSO, 1980-a, p. 6-7.

${ }^{780}$ BITENCOURT, 1999, p. 39.

${ }^{781}$ VALOIS, 2013, p. 106-108.

${ }^{782}$ Necessário ressaltar que se fossem adotadas as novas medidas cautelares previstas no artigo 319, do Código de Processo Penal, muitos presos provisórios poderiam ser retirados das prisões. Hoje, dentre as pessoas que cumprem penas privativas de liberdade no Brasil, $41 \%$ são presos provisórios, ou seja, mais de 230 mil presos (Disponível em: <http://www.cnj.jus.br/images/imprensa/diagnostico_de_pessoas_presas_correcao.pdf>, acesso em 27.10.2014).

783 JESCHECK, 1993, p. 23.
} 
Ademais, o Direito Penal não deve ser utilizado como forma de substituir políticas públicas, pois acaba criando leis dissociadas do sistema penal ${ }^{784}$. Assim, mesmo que se adote um sistema eficiente de cumprimento de penas, tanto privativas quanto não privativas de liberdade, é necessário garantir as condições necessárias para que os egressos retomem sua vida em liberdade.

$\overline{{ }^{784} \text { VALOIS, 2013, p. }} 160$. 


\section{CONCLUSÕES}

1. A partir do século XVIII, a privação de liberdade consolida-se como uma pena criminal em substituição às penas corporais e excessivamente aflitivas. A tortura e os tratamentos e penas cruéis passam a ser proibidos por diversos textos internacionais que se preocupam com a proteção dos direitos humanos e que estabelecem uma busca por formas mais humanas e justas de punir, inaugurando, também, a universalização dos direitos do homem.

2. Em 1945, cria-se a Organização das Nações Unidas, admitindo-se que a proteção dos direitos humanos não se esgota na competência nacional, sendo necessário um órgão para a proteção internacional desses direitos. Forma-se um Direito Internacional Humanitário, obrigando os Estados a reconhecer e proteger os direitos inerentes às pessoas, passando, estes, a trazer em seus textos constitucionais os direitos e princípios trazidos pelos textos internacionais.

3. Dos textos que se destacaram após a Segunda Guerra, tem-se a Convenção Europeia de Direitos Humanos, o Pacto Internacional de Direitos Civis e Políticos, a Convenção Americana de Direitos Humanos e a Convenção contra Tortura e Outros Tratamentos ou Penas Cruéis, Desumanos ou Degradantes, onde é possível observar a preocupação com a humanização das formas de punir, abolindo ou restringindo os tratamentos e penas cruéis, a pena de morte, a pena de caráter perpétuo, a pena de trabalhos forçados, e garantindo às pessoas que cumprem pena privativa de liberdade um tratamento com humanidade, de modo a respeitar a dignidade delas.

4. A Constituição Federal de 1988 elevou a dignidade humana a fundamento da República, conforme previsão do artigo $1^{\circ}$, inciso III, do texto constitucional. Reconhece-se, assim, que toda pessoa é portadora de dignidade, com valor em si mesma e possuidora de direitos fundamentais. A dignidade deve nortear e limitar a ação estatal, que deve guiar suas ações para respeitar cada pessoa e 
possibilitar a elas seu pleno desenvolvimento, removendo óbices para a realização dos direitos previstos na Carta Constitucional.

5. A pessoa condenada criminalmente também deve ter seus direitos fundamentais preservados, sendo o poder punitivo estatal limitado em relação à quantidade e à qualidade da pena. A Constituição Federal traz, em seu artigo $5^{\circ}$, inciso XLVII, a exteriorização do princípio da humanidade, vedando a aplicação de algumas penas em nosso ordenamento jurídico. Este princípio tem como fundamento material a dignidade humana e veda as penas que têm por objetivo o sofrimento do condenado e as que o desconhecem enquanto pessoa, causando padecimento físico ou psíquico além do inerente à privação de liberdade. Neste princípio, encontra-se, também, a diretriz de execução e humanização das penas criminais, que devem ter seu conteúdo aflitivo reduzido e devem compatibilizar o quanto possível a possibilidade de realização dos direitos do condenado com a execução da pena.

6. Em decorrência dos textos internacionais ratificados pelo Brasil e da Constituição Federal, as penas criminais, além do respeito a todos os demais princípios penais, devem respeitar o princípio da humanidade, não podendo ser cominada, aplicada ou executada pena de morte, penas ou tratamentos cruéis, desumanos ou degradantes, penas perpétuas ou de longa duração, pena de banimento, pena de trabalhos forçados e penas meramente retributivas. Ainda, a pena deve considerar as características peculiares de cada pessoa, e o Direito Penal também deve preocupar-se com as vítimas das infrações praticadas. Contudo, mesmo com todas as previsões decorrentes do princípio da humanidade, há um descompasso entre a legislação existente e a aplicação e execução das penas criminais.

7. A execução da pena privativa de liberdade não respeita a dignidade do preso e destoa da legislação brasileira e dos preceitos trazidos pelos textos internacionais. O preso é submetido a tratamento desumano e degradante, em razão da falta de estrutura dos estabelecimentos penais e em razão do tratamento dispensado pelos próprios funcionários dos estabelecimentos $\mathrm{e}$ policiais responsáveis pela guarda dos presos. Não é incomum a denúncia de 
ocorrência de tortura dentro desses locais. Em alguns estabelecimentos penais, os presos são submetidos à rígida disciplina, além da necessária para a manutenção da ordem e organização internas, o que pode acarretar problemas psicológicos futuros no preso. Os direitos dos presos também são desrespeitados e alguns presos são submetidos, ainda, a uma pena cruel, que é o regime disciplinar diferenciado, onde o preso permanece 22 horas por dia isolado em sua cela, sendo esta pena, portanto, excessivamente aflitiva e com objetivo de segregação do preso.

8. Apesar de o Código Penal prever que a pena privativa de liberdade deve ser cumprida de modo progressivo, em razão do entendimento firmado pelo enunciado 715, da Súmula do Supremo Tribunal Federal, é possível que a pena seja cumprida em regime integralmente fechado, por até 30 anos, sem a possibilidade de livramento condicional ou progressão de regime. Com este entendimento, prejudica-se a orientação ressocializadora da pena, permitindo, ainda, a aplicação de uma pena de longa duração, retirando do indivíduo sua esperança de ver-se livre e desestimulando-o a preparar-se para o retorno ao convívio social.

9. O objetivo de reintegração da pena privativa de liberdade não é alcançado, pois, além das violações aos direitos dos presos já citadas, não há estabelecimentos suficientes e adequados para todas as fases de progressão de regime, os programas de estudo e trabalho oferecidos dentro dos estabelecimentos prisionais têm pouca utilidade quando fora da prisão, tendo em vista a qualidade precária deles; e a prisão traz consigo alguns efeitos negativos inerentes a ela e agravados diante do cenário de abandono do cárcere, tais como a prisionização, despersonalização e estigmatização. Estes efeitos, que mais se agravam quanto mais tempo a pessoa fica submetida à pena, dificultam a reintegração do indivíduo com a sociedade.

10. No sistema de aplicação da pena privativa de liberdade, destacam-se, como medidas que tornam as penas mais humanas e menos aflitivas, as penas restritivas de direitos substitutivas da privação de liberdade, em especial a prestação de serviços à comunidade, pois estas evitam o encarceramento de 
curta duração, deixando de submeter uma pessoa aos efeitos perversos do cárcere e dando à pena uma utilidade e um conteúdo positivo, desde que bem executadas. Ademais, a pena de prestação pecuniária atende ao princípio da humanidade no que se refere à atenção que deve ser dada à vítima da infração criminal, pois é uma forma de compensação.

11. A realidade dos hospitais de custódia e tratamento psiquiátrico não diverge da constatada nos estabelecimentos onde se cumpre pena privativa de liberdade, fornecendo aos doentes e deficientes mentais em conflito com a lei um tratamento desumano e degradante que é ainda mais aflitivo do que o constatado nas prisões. Ademais, o tratamento oferecido a essas pessoas pode ser cruel, pois, dependendo do tratamento médico, pode resultar em alteração psíquica da pessoa e dano permanente a sua personalidade e autodeterminação.

12. A legislação penal é omissa em relação ao limite temporal da medida de segurança de internação, o que permite a imposição de uma pena perpétua, contrária ao princípio da humanidade e à Constituição Federal. Apesar de o Poder Judiciário já estar se manifestando no sentido de que essas internações não devem ultrapassar os 30 anos, mesmo limite da pena privativa de liberdade, pode ocorrer que uma pessoa que já passou esse período internada seja desinternada do estabelecimento penal, mas submetida à uma internação em hospital psiquiátrico comum, sob a tutela do juízo cível, permitindo, novamente, uma internação perpétua.

13. O tratamento médico oferecido nestes locais, quando existente, não é capaz de cessar a periculosidade do internado e permitir o seu retorno à sociedade, pois são ineficientes e desatualizados. Com todas as características dos manicômios judiciários, a doença tende a cronificar-se, afastando definitivamente a pessoa de sua família e da sociedade. Ainda, mesmo que o tratamento recomendado a uma pessoa for o ambulatorial, ela pode ser impedida de ter acesso ao melhor tratamento para o seu caso por ter praticado uma infração para a qual é cominada pena de reclusão, pois neste caso a lei impõe a internação. Insta salientar que a medida de segurança não atende à reforma psiquiátrica, 
instituída pela Lei Federal $\mathrm{n}^{\circ}$ 10.216/2011, que estabeleceu o fim das instituições asilares e determinou uma diretriz de desinstitucionalização.

14. Como forma de permitir o retorno das pessoas à sociedade, foi instituída em São Paulo, por meio de uma portaria da Vara das Execuções Criminais, a desinternação progressiva, que, apesar de não estar prevista em lei, é uma medida que respeita a dignidade dos internados, pois permite o seu retorno à sociedade, e de forma gradual e acompanhada.

15. Os adolescentes que cumprem medidas socioeducativas de internação também estão submetidos a tratamentos desumanos e degradantes, sendo submetidos, inclusive, a tortura. Como estão em processo peculiar de transformações físicas e psíquicas, este tratamento que eles recebem pode modificar o modo de ser deles, constituindo uma marca irreversível. Outrossim, a indeterminação do tempo de internação pode resultar, também, na alteração da personalidade do adolescente, que tentará cumprir os requisitos de desinternação.

16. O programa socioeducativo oferecido dentro dos locais de internação não favorece um retorno do adolescente à sociedade em condições de se reintegrar a ela. A qualidade do estudo e da profissionalização é precária e não levam em consideração as necessidades dos adolescentes, sendo, muitas vezes, inútil. Os cursos de profissionalização deveriam oferecer qualificação adequada e certificados de conclusão reconhecidos no mercado de trabalho. Também dificulta o retorno do jovem à sociedade o estigma que o marca, razão pela qual a internação só deveria ser adotada em situação excepcional.

17. No estado de São Paulo, foi criada uma medida para jovens egressos da Fundação Casa, com alta probabilidade de reincidência e periculosidade, conhecida como Unidade Experimental de Saúde. O objetivo desta medida é, em tese, fornecer tratamento de saúde para jovens com transtorno de personalidade antissocial que necessitam de um tratamento de contenção. No entanto, na realidade, esta unidade não tem um projeto terapêutico e não é fornecido um tratamento adequado aos jovens lá internados, funcionando esta medida como meio de inocuização de jovens considerados perigosos, tendo em 
vista, ainda, que a medida foi instituída após grande clamor social. Além de desrespeitar a dignidade do jovem, que passa a ser tratado como mero objeto da intervenção estatal, esta medida permite, também, uma intervenção ilimitada na liberdade da pessoa, podendo ser perpétua. A regulamentação desta medida não previu parâmetros de desinternação nem tempo máximo de internação, deixando o jovem internado sem perspectiva de liberdade, desrespeitando, portando, a proibição constitucional de adoção de penas perpétuas.

18. A dignidade dos adolescentes em conflito com a lei também é violada ao aplicar-se a medida socioeducativa de internação sem o respeito aos requisitos previstos no Estatuto da Criança e do Adolescente e sem atender à excepcionalidade prevista na Constituição Federal. O texto constitucional prevê uma proteção especial à liberdade do adolescente, que só pode ser privada se atender aos princípios da brevidade e da excepcionalidade, contudo, adolescentes estão sendo internados por infrações leves, quando outras medidas socioeducativas seriam mais adequadas ao caso, e por motivos não previstos em lei.

19. Dentre as medidas socioeducativas, algumas também se destacam em razão das consequências positivas que podem resultar da aplicação delas e também em razão do respeito aos preceitos humanitários. São as medidas de reparação do dano e prestação de serviços comunitários. Essas duas medidas, se aplicadas corretamente, podem desenvolver no jovem um sentimento comunitário e de responsabilidade com o bem alheio, mostrar a ele que tem um espaço na sociedade e que é capaz de cumprir as tarefas impostas, surtindo efeitos positivos.

20. Apesar de a Constituição Federal se referir apenas às penas privativas de liberdade no que tange às garantias penais, estas devem alcançar todas as consequências jurídico-criminais que importem em privação de liberdade, como a medida socioeducativa de internação e a medida de segurança na modalidade internação. Em todos esses casos há intervenção estatal na liberdade do indivíduo, que, sem as garantias penais, pode ser ilimitada, permitindo a aplicação de penas e tratamentos constitucionalmente proibidos. 
21. O princípio da humanidade está na Constituição Federal e também em textos internacionais ratificados pelo Brasil. Contudo, ele não é respeitado no Brasil, havendo uma discrepância entre as leis e a execução penal brasileira. Mas, não é apenas em razão da falta de estrutura física e humana que ocorre o desrespeito a este princípio. Isso ocorre também, como visto, em razão do entendimento adotado pelos tribunais e em razão da própria lei, que não condiz com as determinações constitucionais. Portanto, além de maiores investimentos nesta área, são necessárias políticas sociais adequadas, que não podem mais ser substituídas por medidas penais, é necessário um entendimento dos tribunais mais condizente com a humanidade das sanções, como, por exemplo, para respeitar a excepcionalidade das medidas socioeducativas e para tornar mais fácil o livramento condicional e a progressão de regime. É preciso, também, alterações legislativas para, por exemplo, extinguir a Unidade Experimental de Saúde e o regime disciplinar diferenciado, que desrespeitam a dignidade inerente às pessoas submetidas a essas medidas, e para orientar a execução da medida de segurança de acordo com a Lei Federal n 10.216/2001, deixando, ainda, de vincular o tratamento que deve ser imposto, se internação ou ambulatorial, com a pena cominada à infração praticada. 


\section{REFERÊNCIAS}

ABEL Souto, Miguel. Las medidas del nuevo derecho penal juvenil: consideraciones en torno al artículo 7 de la ley penal del menor. Actualidad Penal, Madrid, v. 1, n. 6, p. 105164, fev. 2002.

Abel Souto, Miguel. Teorías de la pena y límites al ius puniendi desde el Estado democrático. Madrid: Dilex, 2006.

ALMEIDA, Eloísa Machado de; et al. Adolescentes suspeitos ou acusados da autoria de atos infracionais em São Paulo - Convênio Ilanud/Febem-SP/PAJ - Infância e Juventude. Revista Brasileira de Ciências Criminais, São Paulo, v. 38, p. 165-209, abr./jun. 2002.

AlMEIDA, José Eulálio Figueiredo de. Sursis como medida sancionatória substitutiva da pena privativa de liberdade. Revista Síntese de Direito Penal e Processual Penal, Porto Alegre, v. 4, n. 22, p. 25-32, out./nov. 2003.

Álvarez, Alejandro E. Acerca del consentimiento en una teoría consensual de la pena. Cuadernos de Doctrina y Jurisprudencia Penal, Buenos Aires, v. 5, n. 9A, p.257270, set. 1999.

Amaral, Claudio do Prado. Princípios penais: da legalidade à culpabilidade. São Paulo: IBCCRIM - Instituto Brasileiro de Ciências Criminais, 2003. v. 24.

ANDRADE, Anderson Pereira de. Aplicação de medidas socioeducativas privativas de liberdade e direitos fundamentais. Boletim Científico - Escola Superior do Ministério Público da União, Brasília, ano 1, n. 5, p. 9-20, out./dez., 2002.

ANTONINI, José Roberto. Uma experiência democrática na administração penitenciária. Revista dos Tribunais, São Paulo, ano 79, n. 657, p. 386-390, jul. 1990. 
ArAúJo, Fábio Roque da Silva. Medida de segurança: caráter residual da internação. Revista IOB de Direito Penal e Processual Penal, Porto Alegre, v. 10, n. 57, p. 7-15, ago./set. 2009.

AraúJo, Fábio Roque da Silva. Omissão estatal e prisão domiciliar. Revista Magister de Direito Penal e Processual Penal, Porto Alegre, v. 9, n. 51, p. 56-59, dez./jan. 2013.

Araújo, Fábio Roque da Silva. Prazos (mínimo e máximo) das medidas de segurança. Revista Magister de Direito Penal e Processual Penal, Porto Alegre, v. 4, n. 22, p. 55-67, fev./mar. 2008.

ARBEX, Daniela. Holocausto brasileiro - Genocídio: 60 mil mortos no maior hospício do Brasil. São Paulo: Geração, 2013.

AZEVEDO, Juarez Morais de. A humanização da pena de prisão e a associação de proteção e assistência aos condenados - APAC. In: MARCHI JR, Antônio de Padova; PINTO, Felipe Martins (Coord.). Execução penal - constatações, críticas, alternativas e utopias. Curitiba: Juruá, 2008. p. 289-302.

BARbero SAntos, Mariano. La pena de muerte en España: historia de su abolición. Doctrina Penal: Teoría y prática en las ciencias penales, Buenos Aires, v. 3, n. 9-12, p. 205-218, 1980.

BARATTA, Alessandro. Criminología y sistema penal: compilación in memorian. Montevidéu: Editoriao B de F, 2004.

BARreto, Djalma. O alienista, o louco e a lei. Petrópolis: Vozes, 1978.

BArros, Carmen Silvia de Moraes. Aplicação da reforma psiquiátrica e da política de saúde mental ao louco infrator. In: BoRges, Paulo César Corrêa. Marcadores sociais da diferença e repressão penal. São Paulo: Cultura Acadêmica, 2011. p. 213-219.

BÁrtoli, Márcio Orlando. Penas alternativas: crimes da mesma natureza - socialmente recomendável - o art. 44 par. 3., do CP. In: Escritos em homenagem a Alberto Silva Franco. São Paulo: Revista dos Tribunais, 2003. p. 293-301. 
BAtista, Nilo. Introdução crítica ao direito penal brasileiro. Rio de Janeiro: Revan, 2001.

BAtISTA, Vera Malaguti. Difíceis ganhos fáceis: drogas e juventude pobre no Rio de Janeiro. $2^{\mathrm{a}}$ ed. Rio de Janeiro: Revan, 2003.

BeCCARIA, Cesare. Dos delitos e das penas. $3^{\mathrm{a}}$. ed. São Paulo: Editora Revista dos Tribunais, 2006.

BetTiOL, Giuseppe. Direito penal. v. 3. São Paulo: Revista dos Tribunais, 1976.

Bettiol, Giuseppe. O mito da reeducação. Revista Brasileira de Criminologia e Direito Penal, Rio de Janeiro, v. 2, n. 6, p. 5-17, jul./set. 1964.

BITENCOURT, Cezar Roberto. Novas penas alternativas: análise político-criminal das alterações da lei n. 9.714/98. São Paulo: Saraiva, 1999.

Bitencourt, Cezar Roberto. Falência da pena de prisão: causas e alternativas. $4^{\mathrm{a}}$ ed. São Paulo: Saraiva, 2011 (a).

BITENCOURT, Cezar Roberto. Tratado de direito penal: parte geral : volume I. 16 a ed. São Paulo: Saraiva, 2011 (b).

Blanco Lozano, Carlos; Tinoco Pastrana, Ángel. Prisión y resocialización. Madrid: Difusión Jurídica, 2009.

Bottini, Pierpaolo Cruz. Aspectos pragmáticos e dogmáticos do monitoramento eletrônico. In: Brasil. Ministério DA JustiçA. Conselho Nacional DE PolíticA CRIMINAl E PENITENCIÁRIA. Monitoramento eletrônico: uma alternativa à prisão?; experiências internacionais e perspectivas no Brasil. Brasília: CNPCP, 2008. p. 167-180.

BRANDÃO, Nuno. Limites de duração da medida de segurança de internamento: acordão do Supremo Tribunal de Justiça de 12 de abril de 2000. Revista Portuguesa de Ciência Criminal, Coimbra, v. 10, n. 4, p. 613-628, out./dez. 2000. 
Brant, Vinícius Caldeira. O trabalho encarcerado. Forense: Rio de Janeiro, 1994.

BRASIL. Câmara dos Deputados. I Caravana Nacional de Direitos Humanos: uma amostra da realidade manicomial brasileira. Brasília: Centro de documentação e informação/ Coordenação e Publicações, 2000.

BrASIL. Conselho Nacional de Justiça. Panorama Nacional - A execução das medidas socioeducativas de internação, Programa Justiça ao Jovem, 2012, p. 11. Disponível em: < http://www.cnj.jus.br/images/pesquisas-

judiciarias/Publicacoes/panorama_nacional_doj_web.pdf>, acesso em 02.11.2014.

Brasil. Ministério da Justiça. Conselho Nacional de Política Criminal e Penitenciária. Relatório sobre inspeção em estabelecimentos penais do estado de São Paulo, julho de 2011. Disponível em: $<$ http://portal.mj.gov.br/services/DocumentManagement/FileDownload.EZTSvc.asp?Docu mentID $=\{0 B C 48 F B 8-0 E 4 C-4 C 85-9770-21333 D 4 C 13 F 9\} \&$ ServiceInstUID $=\{4 A B 01622-$ 7C49-420B-9F76-15A4137F1CCD\}>, acesso em 17.08.2014.

BRASIL. Superior Tribunal de Justiça. Habeas corpus $n^{o} 271.466$, da $5^{\text {a }}$ Turma, Rel.: Ministro Feliz Fischer, j. 16.09.2014, DJe 25.09.2014.

BRASIL. Superior Tribunal de Justiça. Habeas corpus $n^{o} 291.650$, da $5^{\text {a }}$ Turma, Rel.: Ministro Moura Ribeiro, j. 20.05.2014, DJe 23.05.2014.

BRASIL. Superior Tribunal de Justiça. Habeas corpus $n^{o}$ 299.257, da $6^{\text {a }}$ Turma, Rel.: Ministro Nefi Cordeiro, j. 09.09.2014, DJe 25.09.2014.

BRASIL. Superior Tribunal de Justiça. Recurso Ordinário em Habeas Corpus $n^{o}$ 33.638/RJ, da 6a Turma, Rel.: Ministra Maria Thereza de Assis Moura, j. 05.08.2014, DJe 18.08.2014.

BRASIL. Supremo Tribunal Federal. Habeas corpus $n^{\circ}$ 84.219-4/SP, Rel.: Ministro Marco Aurélio, j. 16.08.2005, DJ 23.09.2005. 
Brasil. Supremo Tribunal Federal. Habeas corpus $n^{o}$ 85.401/RS, Rel.: Ministro Cezar Peluso, j. 04.12.2009, DJe 12.02.2010.

BRASIL. Supremo Tribunal Federal. Habeas corpus $n^{o}$ 88.748/SP, Rel.: Sepúlveda Pertence, j. 08.08.2006, DJ 29.09.2006.

BRASIL. Supremo Tribunal Federal. Habeas corpus $n^{\circ}$ 97.256/RS, plenário, Rel.: Ministro Ayres Britto, j. 01.09.2010, DJ 16.12.2010.

BRASIL. Supremo Tribunal Federal. Habeas corpus $n^{o}$ 107.777/RS, da $2^{\mathrm{a}}$ Turma, Rel.: Ministro Ayres Britto, j. 07.02.2012, DJe 16.04.2012.

BRASIL. Supremo Tribunal Federal. Habeas corpus $n^{\circ} 118.492$, da $2^{\mathrm{a}}$ Turma, Rel.: Ministro Ricardo Lewandowski, j. 06.11.2013, DJe 19.11.2013.

CAmargo, Antonio Luis Chaves. Sistemas de penas, dogmática jurídico-penal e política criminal. São Paulo: Cultural Paulista, 2002.

CARrARA, Sérgio. Crime e loucura: o aparecimento do manicômio judiciário na passagem do século. Rio de Janeiro: Eduerj / Edusp, 1998.

Carvalho, Márcia Dometila Lima de. Fundamentação constitucional do direito penal. Porto Alegre: Sergio Antonio Fabris, 1992.

Carvalho, Salo de. Aplicação da pena no estado democrático de direito: postulados garantistas. In: CARvalho, Amílton Bueno de. Aplicação da pena e garantismo. 3.ed. ampl. Rio de Janeiro: Lumen Juris, 2004. p. 1-98.

CARvalho, Salo de. Pena e garantias: a crise do direito e do processo penal / o garantismo jurídico / as teorias da pena / os sistemas de execução / a lei de execução penal / os conflitos carcerários / os direitos (de resistência) dos presos. 2. ed. Rio de Janeiro: Lumen Juris, 2003. 
Carvalho, Salo de. Penas e medidas de segurança no Direito Penal Brasileiro. $1^{\mathrm{a}}$ ed., $2^{\mathrm{a}}$ tir. São Paulo: Saraiva, 2013.

Carvalho, Salo de; Freire, Christiane Russomano. O regime disciplinar diferenciado: notas críticas à reforma do sistema punitivo brasileiro. Revista Transdisciplinar de Ciências Penitenciárias, Pelotas, v. 4, n. 1, p. 7-26, jan./dez. 2005.

CAStro, Ana Márcia de Souza. Alternativas ao jovem infrator. Revista do ILANUD, São Paulo, n. 12, p. 17-24, 1998.

CAstro, Vivian Monsef de. O adolescente infrator e os direitos humanos. Revista da Defensoria Pública, São Paulo, Ed. especial temática sobre infância e juventude, n. 3, p. 137-141, 2008.

Cataldo Neto, Alfredo; Gauer, Gabriel José Chittó. Uma leitura constitucional das internações psiquiátricas. In: FAYET JR, Ney; MAYA, André Machado (Org.). Ciências penais e sociedade complexa II. Porto Alegre: Nuria Fabris, 2009. p. 11-29.

CATÃo, Yolanda; SÜSSEKIND, Elisabeth. Os direitos do preso. In: Fragoso, Heleno Cláudio; CATÃo, Yolanda; SÜSSEKIND, Elisabeth. Direitos dos presos. Rio de Janeiro: Forense, 1980. p. 49-127.

Corte Europeia de Direitos Humanos. Caso Bader e Kanbor Vs. Suécia, de 8 de $\begin{array}{llll}\text { novembro de } & \text { 2005, disponível em }\end{array}$ $<$ http://hudoc.echr.coe.int/sites/eng/pages/search.aspx?i=001-70841>, acesso em 16.06.2014.

Corte Europeia de Direitos Humanos. Caso Vinter e outros Vs. Reino Unido, de 9 de julho de 2013, disponível em <http://hudoc.echr.coe.int/sites/fra/pages/search.aspx?i=001122664>, acesso em 16.06.2014.

Corte Europeia de Direitos Humanos. The Greek Case. In: Yearbook of the European Convention on Human Rights, nº 12, 1969. Martinus Nÿhoff, 1972. 
Cernicchiaro, Luiz Vicente. Princípio da individualização da pena. In: Cernicchiaro, Luiz Vicente; Costa JR, Paulo José da. Direito penal na Constituição. 3.ed. rev. e ampl. São Paulo: Revista dos Tribunais, 1995. p. 117-154. (a)

Cernicchiaro, Luiz Vicente. Princípio da legalidade. In: Cernicchiaro, Luiz Vicente; Costa JR., Paulo José da. Direito penal na Constituição. 3.ed. rev. e ampl. São Paulo: Revista dos Tribunais, 1995. p. 11-59. (b)

CERniCChIARO, Luiz Vicente. Pena: cumprimento integral em regime fechado. In: Escritos em homenagem a Alberto Silva Franco. São Paulo: Revista dos Tribunais, 2003. p. 288292.

CIA, Michele. Medidas de segurança no direito penal brasileiro: a desinternação progressiva sob uma perspectiva político-criminal. São Paulo: UNESP, 2011.

Cintra, Antônio Carlos de Araújo; Dinamarco, Cândido Rangel; Grinover, Ada Pellegrini. Teoria geral do processo. $16^{\text {a }}$ ed. São Paulo: Malheiros, 2000.

CINTRA JR., Dyrceu Aguiar Dias. Direitos humanos e saúde mental. In: Escritos em homenagem a Alberto Silva Franco. São Paulo: Revista dos Tribunais, 2003. p. 151-162.

CIRENZA, Cristina de Freitas; NunEs, Clayton Alfredo. Convenção contra a tortura e outros tratamentos ou penas cruéis, desumanas ou degradantes e convenção interamericana para prevenir e punir a tortura. In: São PAulo (Estado). Procuradoria Geral do Estado. Grupo de Trabalho de Direitos Humanos. Direitos humanos: construção da liberdade e da igualdade. São Paulo: Centro de Estudos da Procuradoria Geral do Estado de São Paulo, 1998. p. 405-442.

Coletivo EM DEFESA dos DiREITOS DO(A) JOVEM PRIVAdO(A) DE LIBERDADE NA FEBEM/FCASA. Relatório de fiscalização às unidades de internação em estabelecimento educacional da Fundação Casa - SP, dezembro de 2008. 
Conselho Nacional de JustiçA. Departamento de Monitoramento e Fiscalização do Sistema Carcerário e do Sistema de Execução de Medidas Socioeducativas - DMF. Novo diagnóstico de pessoas presas no Brasil, junho de 2014. Disponível em: http://www.cnj.jus.br/images/imprensa/diagnostico_de_pessoas_presas_correcao.pdf, acesso em 17.08.2014.

Conselho Nacional de JustiçA. Panorama Nacional - A execução das medidas socioeducativas de internação, Programa Justiça ao Jovem, 2012, p. 11. Disponível em: < http://www.cnj.jus.br/images/pesquisas-

judiciarias/Publicacoes/panorama_nacional_doj_web.pdf>, acesso em 02.11.2014.

Corte Interamericana de Direitos Humanos. Caso Bueno Alves Vs. Argentina, de 11 de maio de 2007, disponível em http://www.corteidh.or.cr/docs/casos/articulos/seriec_164_esp.pdf>, acesso em 16.06.2014.

Corte Interamericana de Direitos Humanos. Caso Yvon Neptune Vs. Haiti, de 6 de maio de 2008, disponível em <http://www.corteidh.or.cr/docs/casos/articulos/seriec_180_esp1.pdf>, acesso em 16.06.2014.

Corte Interamericana de Direitos Humanos. Parecer Consultivo OC-3/83, Série A, No. 3, de 8 de setembro de 1983, disponível em <http://www.corteidh.or.cr/docs/opiniones/seriea_03_esp.pdf>, acesso em 16.06.2014.

CostA, Álvaro Mayrink da. Medidas de segurança. In: LIMA, Marcellus Polastri; RIBEIRO, Bruno de Morais (Coord.). Estudos criminais em homenagem a Weber Martins Batista. Rio de Janeiro: Lumen Juris, 2008. p. 3-24.

Costa, Cláudio Hortêncio. Medidas sócio-educativas e a conjuntura. Revista do ILANUD, São Paulo, n. 14, p. 37-38, 2001. 
CostA, Débora Dayse Tavares da. O regime disciplinar diferenciado ante os princípios da isonomia, dignidade da pessoa humana e da relatividade dos direitos fundamentais: garantia do direito do preso não perigoso ao cumprimento da pena e à ressocialização. Revista da ESMAPE, Recife, v. 11, n. 23, p. 425-450, jan./jun. 2006.

CostA, Helena Regina Lobo da. A dignidade humana: teorias de prevenção geral positiva. São Paulo: Revista dos Tribunais, 2008.

Costa JR., Paulo José da. Presunção normativa de perigosidade e jurisdicionalização da medida de segurança. Revista Brasileira de Criminologia e Direito Penal, Rio de Janeiro, v. 1, n. 1, p.137-141, abr./jun. 1963.

Costa JR., Paulo José da. Da inutilidade da pena capital. In: Pena de morte. Coimbra: Faculdade de Direito da Universidade de Coimbra, 1967. v 2. p.105-109.

DE LA Cuesta ARZAmendi, José Luis. El principio de humanidad en derecho penal. Eguzkilore: Cuaderno del Instituto Vasco de Criminología, San Sebastian, n. 23, p. 209-225, 2009.

DE la Cuesta ArZamendi, José Luis. Entre la ley de seguridad ciudadana y la ley sobre prevención y tratamiento de las drogodependencias del país vasco. Eguzkilore: Cuaderno del Instituto Vasco de Criminología, San Sebastian, n. 6, p. 91-95, dez. 1992.

DEL MonTE, Thaís. Reflexos das novas formas de criminalidade nos princípios limitadores do poder punitivo estatal. Revista de Estudos Jurídicos UNESP, Franca, n. 23, p.285-310, jan./jul. 2012.

Delmanto, Roberto; Delmanto JR., Roberto; Delmanto, Fabio Machado de Almeida. Perda de bens e multa substitutiva. Boletim IBCCRIM, São Paulo, v. 7, n. 85, p. 10, dez. 1999.

Delmas-Marty, Mireille. Humanidade, espécie humana e direito penal. Revista Brasileira de Ciências Criminais, São Paulo, v. 100, p.141-154, jan./fev. 2013. 
DinIZ, Débora. A custódia e o tratamento psiquiátrico no Brasil: censo 2011. Brasília: Letras Livres/ UNB, 2013.

DotTI, René Ariel. Penas e medidas de segurança no anteprojeto de código penal. Revista de Direito Penal, Rio de Janeiro, n. 32, p. 46-69, jul./dez. 1981.

DotTI, René Ariel. Bases e alternativas para o sistema de penas. São Paulo: Revista dos Tribunais, 1998.

DotTI, René Ariel. O Sistema geral das penas. In: DotTI, René Ariel; REALE JR., Miguel; Toledo, Francisco de Assis; SheCAIRA; Sergio Salomão; AzEVEdo; David Teixeira de; LOPES, Mauricio Antonio Ribeiro. (Orgs.). Penas restritivas de direitos: Críticas e comentários às penas alternativas. São Paulo: Revista dos Tribunais, 1999. p. 65-128.

DotTI, René Ariel. Visão geral da medida de segurança. In: SHECAIRA, Sérgio Salomão (Org.). Estudos criminais em homenagem a Evandro Lins e Silva: criminalista do século. São Paulo: Método, 2001. p. 309-326.

DuARTE, Arnaldo Rodrigues. A pena e a medida de segurança em face do anteprojeto do ministro Nelson Hungria. Revista Brasileira de Criminologia e Direito Penal, Rio de Janeiro, v.1, n.4, p. 139-143, jan./mar. 1964.

Elias, Roberto Joao. Comentários ao Estatuto da Criança e do Adolescente (Lei n. 8.069, de 13 de julho de 1990). $3^{\text {a }}$ ed. São Paulo: Saraiva, 2008.

FARIA, Antonio Celso Campos de Oliveira. O direito à integridade física, psíquica e moral e a pena privativa de liberdade. Revista Brasileira de Ciências Criminais, São Paulo, v. 6, n. 22, p.51-61, abr./jun. 1998.

FARIA, Josiane Petry; OliveIRA, Landiele Chiamente de. Princípio da humanidade das penas e a inconstitucionalidade do regime disciplinar diferenciado no direito penal brasileiro. Revista Justiça do Direito, Passo Fundo, v. 21, n. 1, p. 98-111, 2007. 
FERNANDES, Newton. A falência do sistema prisional brasileiro. São Paulo: RG Editores, 2000.

FERRARI, Eduardo Reale. As medidas de segurança criminais e sua progressão executória: desinternação progressiva. In: SHECAIRA, Sérgio Salomão (Org.). Estudos criminais em homenagem a Evandro Lins e Silva: criminalista do século. São Paulo: Método, 2001. p. 127-133.

FERREIRA, Fábio Felix; CUTIÑo RAYA, Salvador. Da inconstitucionalidade do isolamento em cela e do regime disciplinar diferenciado. Revista Brasileira de Ciências Criminais, São Paulo, v. 12, n. 49, p. 251-290, jul./ago. 2004.

FEUERBACH, Paul Johann Anselm Ritter von. Tratado de derecho penal común vigente en Alemania. Tradução de Eugenio Raúl Zaffaroni e Irma Hagemeier. Buenos Aires: Hammurabi, 2007.

FigueIREDO, Frederico Antunes de Oliveira. Da participação da comunidade na execução das penas privativas de liberdades. Revista do Conselho Nacional de Política Criminal e Penitenciária, Brasília, n. 16, p. 55-70, jan./jul. 2003.

FIRMO, Maria de Fátima Carrada. A criança e o adolescente no ordenamento jurídico brasileiro. Rio de Janeiro: Renovar, 1999.

Fragoso, Heleno Cláudio. Alternativas da pena privativa de liberdade. Revista de Direito Penal, Rio de Janeiro, n. 29, p. 5-17, jan./jun. 1980. (a)

Fragoso, Heleno Cláudio. Lições de direito penal: parte geral. 16. ed. Rio de Janeiro: Forense, 2004.

Fragoso, Heleno Cláudio. Que Direito? In: Fragoso, Heleno Cláudio; CATÃo, Yolanda; SÜSSEKIND, Elisabeth. Direitos dos presos. Rio de Janeiro: Forense, 1980. p. 1-48. (b) 
Franco, Alberto Silva; LiRA, Rafael; Felix, Yuri. Crimes hediondos. 7. ed. São Paulo: Revista dos Tribunais, 2011.

Frasseto, Flávio Américo. Ato infracional, medida socioeducativa e processo: a nova jurisprudência do STJ. Discursos Sediciosos: crime, direito e sociedade, Rio de Janeiro, v. 7, n. 12, p. 167-191, 2002.

FRASSETO, Flávio Américo. Fronteiras psi-jurídicas dos casos de interdição em andamento em São Paulo e a questão da Unidade Experimental de Saúde. In: ConSELHO REGIONAL DE PSICOlOGIA DA 6 $6^{\mathrm{a}}$ REGIÃo (org.). Políticas de saúde mental e juventude nas fronteiras psijurídicas, São Paulo: CRP SP, 2011. p. 9-14.

GARCÍA MÉNDEZ, Emilio. Adolescentes y responsabilidad penal: un debate latinoamericano. Revista Brasileira de Ciências Criminais, São Paulo, v. 12, n. 48, p. 229245, mai./jun. 2004.

Gerlack Neto, Martinho Otto. O resgate do sistema progressivo de execução da pena [Comentário de jurisprudência]. Revista Brasileira de Ciências Criminais, São Paulo, v. 14, n. 63, p. 333-350, nov./dez. 2006.

GiacomuzzI, Vladimir. Sistema progressivo de cumprimento da pena privativa de liberdade. In: FAYET JR, Ney; WEDY, Miguel Tedesco (Org.). Estudos críticos de direito e processo penal: em homenagem ao Des. Garibaldi Almeida Wedy. Porto Alegre: Livraria do Advogado, 2004. p. 215-220.

GOMES, Geder Luiz Rocha. A trajetória da central nacional de penas e medidas alternativas do Ministério da Justiça. Revista do Conselho Nacional de Política Criminal e Penitenciária, Brasília, v. 1, n. 21, p. 95-119, 2008.

Gomes Neto, Gercino. O adolescente autor de ato infracional frente aos princípios e garantias do Estatuto da criança e do adolescente. Revista do ILANUD, São Paulo, n. 14, p. 43-53, 2001. 
GoMes, Mariângela Gama de Magalhães. O princípio da proporcionalidade no direito penal. São Paulo: Revista dos Tribunais, 2003.

GonçALVES, Antonio Baptista. A única pena de prisão perpétua no Brasil: o manicômio. Boletim do Instituto de Ciências Penais, Belo Horizonte, v. 5, n. 72, p.2-4, ago. 2006.

Goulart, Henny. Penologia I. $8^{a}$ ed. São Paulo: Editora Brasileira de Direito, 1985.

Gracia MARTín, Luis. Sobre la legitimidad de medidas de seguridad contra delincuentes imputables peligrosos en el estado de derecho. In: GARCIA VALDÉs, Carlos et al (Coord.). Estudios penales en homenaje a Enrique Gimbernat I. Madrid: Edisofer, 2008. p. 9751003.

GRECO, Rogério. Direitos humanos, sistema prisional e alternativas à privação de liberdade. São Paulo: Saraiva, 2011.

GuZMÁn DÁlbora, José Luis. Justicia penal y principio de humanidad. In: Avalos Rodríguez, Constante Carlos; Quispe Villanueva, Alejandro Emilio (Coord.). Dogmática penal del tercer milenio: libro homenaje a los profesores Eugenio Raúl Zaffaroni y Klaus Tiedemann. Lima: Ara, 2008. p. 283-298.

HASSElein, Karin Soares; CALDEIRA, Marconi. Medidas de segurança, tratamento ambulatorial: entre os limites de sua aplicação e o princípio da individualização da pena. Revista Sintese de Direito Penal e Processual Penal, Porto Alegre, v. 13, n. 78, p.927, fev./mar. 2013.

Herzog, Jacques-Bernard. Adolescentes e jovens adultos delinqüentes. Revista Brasileira de Criminologia e Direito Penal, Rio de Janeiro, v. 1, n. 3, p. 5-16, out./dez. 1963.

IGNACIO BAÑOS, Javier. El fundamento de la pena: máximo problema penal. Buenos Aires: Ediar, 2011. 
JACOBINA, Paulo Vasconcelos. Direito penal da loucura: medida de segurança e reforma psiquiátrica. Brasília: ESMPU, 2008.

JACOBINA, Paulo Vasconcelos. Direito penal da loucura: medida de segurança e reforma psiquiátrica. Boletim dos Procuradores da República, Brasília, ano VI, nº 70, p. 16-21, abr. 2006.

JESCHECK, Hans-Heinrich. Tratado de derecho penal: parte general. 4. ed. Granada: Comares, 1993.

Juliotti, Pedro de Jesus. A pena privativa de liberdade, o regime disciplinar diferenciado e a dignidade da pessoa humana. Justitia, São Paulo, v. 65, n. 198, p. 27-34, jan./jun. 2008.

JUNQUeIRA, Ivan de Carvalho. Do ato infracional à luz dos direitos humanos. Campinas: Russell, 2009.

KARAM, Maria Lúcia. Disciplina do livramento condicional no ordenamento jurídico-penal brasileiro e violações a direitos fundamentais. In: MARCHI JR, Antônio de Padova; PINTO, Felipe Martins (Coord.); Fernandes, Agostinho; LaCERDA, Bruno Amaro (Colab.). Execução penal: constatações, críticas, alternativas e utopias. Curitiba: Juruá, 2008. p. 149-182.

KARAM, Maria Lúcia. Regimes de cumprimento da pena privativa de liberdade e supremacia da ordem constitucional. In: Escritos em homenagem a Alberto Silva Franco. São Paulo: Revista dos Tribunais, 2003. p. 309-323.

LEAL, César Barros. O sistema penitenciário: da desesperança ao otimismo responsável. Revista do Conselho Nacional de Política Criminal e Penitenciária, Brasília, n. 16, p. 29-34, jan./jul. 2003.

LEÃO, Nilzardo Carneiro. Crimes contra o estado democrático e a humanidade: para a história do CNPCP. Revista do Conselho Nacional de Política Criminal e Penitenciária, Brasília, v. 1, n. 8, p.123-144, jul./dez. 1996. 
LERNER, Gabriel. Sistema integral de justicia penal para adolescentes: la necesidad de una reforma transicional. Revista de derecho penal y procesal penal, Buenos Aires, n. 7, p. 1183-1191, jul. 2009.

LEVorin, Marco Polo. Direitos humanos e medida de segurança. Boletim IBCCRIM, São Paulo, v. 12, n. 141, p.6-7, ago. 2004.

Levorin, Marco Polo. Princípio da legalidade na medida de segurança: determinação do limite máximo de duração da internação. São Paulo: Juarez de Oliveira, 2003.

LimA, Carlos Daniel Vaz. Novas tecnologias na humanização da pena, abr. 2008, artigo digital disponível em <http://carlosdaniel.net/?p=4>, acesso em 15.08.2014.

Lima, Carolina Alves de Souza; Marques, Oswaldo Henrique Duek. O princípio da humanidade das penas. In: MiRANDA, Jorge; SilvA, Marco Antonio Marques da (Coords.). Tratado luso-brasileiro da dignidade humana. 2. ed. São Paulo: Quartier Latin, 2009. p. 439-447.

LIRA, Rafael. O Direito por quem o faz - Execução penal. Medida de segurança. Princípio da dignidade da pessoa humana. Morosidade da prestação jurisdicional. Ineficiência do estado. Constrangimento ilegal. Boletim IBCCRIM, São Paulo, n. 238, set. 2012.

LUISI, Luiz. O princípio da humanidade. Revista da Escola do Serviço Penitenciário do Rio Grande do Sul, Porto Alegre, n. 8, p. 147-151, jul./set. 1991.

Macaulay, Fiona. Os centros de ressocialização no Estado de São Paulo: Estado e sociedade civil em um novo paradigma de administração prisional e de reitegração de ofensores. Revista de Estudos Criminais, Porto Alegre, v. 7, n. 26, p. 63-86, jul./set. 2007.

Machado Pelloni, Fernando M. Argumentos contra la tortura y los tratos crueles, inhumanos y degradantes. In: FAYET JR, Ney; MAYA, André Machado (Orgs.). Ciências penais: perspectivas e tendências da contemporaneidade. Curitiba: Juruá, 2011. p.13-50. 
MACIEL, Adhemar Ferreira. Aspectos penais na Constituição. Revista Brasileira de Ciências Criminais, São Paulo, n. 13, p. 93-97, jan./mar. 1996.

MAdEIRA, Lígia Mori. A atuação da sociedade civil na ressocialização de egressos do sistema penitenciário: a FAESP como objeto de pesquisa. Revista Transdisciplinar de Ciências Penitenciárias, Pelotas, v. 2, n. 1, p. 97-117, jan./dez. 2003.

MaIA Neto, Cândido Furtado. Aplicação de medidas de segurança aos enfermos mentais. MPD Dialógico: Revista do Movimento Ministério Público Democrático, São Paulo, v. 8, n. 36, p. 30-31, 2012.

Maglio, Maria Fernanda dos Santos Elias. Da medida de segurança e da medida sócioeducativa: as semelhanças entre os destinos conferidos aos adolescentes e loucos autores de delitos. Revista da Defensoria Pública, São Paulo, Ed. especial, nº 3, p. 81-88, 2008.

MARCHI JR., Antônio de Padova. Da importância da fiscalização permanente e das visitas mensais aos estabelecimentos prisionais. In: MARCHI JR, Antônio de Padova; PINTO, Felipe Martins (Coord.); Fernandes, Agostinho; LaCERdA, Bruno Amaro (Colab.). Execução penal: constatações, críticas, alternativas e utopias. Curitiba: Juruá, 2008. p. 305-314.

MARques, José Frederico. Estudos de Direito Processual Penal. $2^{\mathrm{a}}$ ed. Campinas: Millennium, 2001.

Martin-Chenut, Kathia Regina. Adolescentes em conflito com a lei: o modelo de intervenção preconizado pelo Direito Internacional dos Direitos Humanos. Revista do ILANUD, São Paulo, n. 24, p. 79-102, 2003.

Martos NúÑEZ, Juan Antonio. Principios penales en el estado social y democrático de derecho. Revista de Derecho Penal y Criminología, Madrid, n. 1, p. 217-296, 1991.

MAtTos, Renata Soares Bonavides de. Direitos do presidiário e suas violações. São Paulo: Método, 2002. 
Melo, Vicente Paulo Alberto de. Uma experiência de trabalho no âmbito prisional: oficiais de expressão. Revista Transdisciplinar de Ciências Penitenciárias, Pelotas, v. 2, n. 1, p.173-178, jan./dez. 2003.

Messias, Simone Fagundes. Manicômio judiciário e a Lei de Execução Penal: garantias e violações. Revista Transdisciplinar de Ciências Penitenciárias, Pelotas, v. 4, n. 1, p. 3949, jan./dez. 2005.

MinAhim, Maria Auxiliadora; SposATo, Karyna Batista. A internação de adolescentes pela lente dos tribunais. Revista Direito GV, São Paulo, v. 7, n. 1, p. 277-298, jan./jun. 2011.

MIR PUIG, Santiago. Derecho penal: parte general. 9. ed. Madrid: Edisofer, 2011.

Mirabete, Júlio Fabbrini; Fabbrini, Renato N. Execução Penal. 12ª ed. São Paulo: Atlas, 2014.

Monge GonZÁlez, Almudena. La pena de muerte en Europa. In: GARCíA VAldés, Carlos (dir.). História de la prisión: teorías economicistas, crítica - curso de doctorado. Madrid: Edisofer, 1997. p. 25-43.

Moraes, Alexandre de. Direito Constitucional. 29a ed. São Paulo: Atlas, 2013.

MourA, Maria Thereza Rocha de Assis. Notas sobre a inconstitucionalidade da lei n. 10.792/2003, que criou o regime disciplinar diferenciado na execução penal. Revista do Advogado, São Paulo, v. 24, n. 78, p. 61-66, set. 2004.

MourA, Maria Thereza Rocha de Assis. O IBCCRIM e a inconstitucionalidade da proibição de progressão nos crimes hediondos. Boletim IBCCRIM, São Paulo, v. 20, n. 237 - Edição Especial, p.6-7, ago. 2012.

MuAKad, Irene Batista. Pena privativa de liberdade. São Paulo: Atlas, 1996. 
NAHUM, Marco Antonio Rodrigues. O retorno dos conceitos de periculosidade, e de inocuização, como defesa da sociedade globalizada. Boletim IBCCRIM, São Paulo, v. 13, n. 161 , p.14-15, abr. 2006.

NASCIMENTO, José Flávio Braga. Imputabilidade do menor sob a ótica criminológica. São Paulo: Juarez de Oliveira, 2007.

NASH RoJAS, Claudio. Alcance del concepto de tortura y otros tratos crueles, inhumanos y degradantes. In: ELSNER, Gisela (Ed.). Anuario de derecho constitucional latinoamericano 2009. Montevidéu: Konrad-Adenauer-Stiftung, 2009. p. 585-601.

SAlVAdOR NetTo, Alamiro Velludo. Finalidades da pena: conceito material de delito e sistema penal integral. São Paulo: Quartier Latin, 2009.

NogueIRA, José Carlos de Ataliba. Pena sem prisão. $2^{\text {a }}$ ed. São Paulo: Saraiva, 1956.

NuCCI, Guilherme de Souza. Manual de direito penal. 9. ed. São Paulo: Revista dos Tribunais, 2013.

NúÑEZ, María Elena. La peligrosidad. In: CovELli, José Luis et al. Imputabilidad y capacidad de culpabilidad: perspectivas médicas e jurídico-penales. Buenos Aires: Dosyuna, 2009. p.131-141.

OliveIRA, Gláucio Araújo de. Trabalho penitenciário à luz da lei de execução penal. In: MARChi JR, Antônio de Padova; Pinto, Felipe Martins (Coord.); FernAndes, Agostinho; LACERDA, Bruno Amaro (Colab.). Execução penal: constatações, críticas, alternativas e utopias. Curitiba: Juruá, 2008. p. 257-288.

Organização das NaçÕes Unidas. Comitê de Direito Humanos. Comunicación $n^{o}$ 265/1987: Finland. 02/05/1989/CCPR/C/35/D/265/1987, abril de 1989, disponível em <http://www1.umn.edu/humanrts/hrcommittee/spanish/265-1987.html>, acesso em 19.06.2014. 
OrganizaÇão DAS NAÇões Unidas. Subcomitê de Prevenção da Tortura e outros Tratamentos ou Penas Cruéis, Desumanos ou Degradantes. Relatório sobre a visita ao Brasil do Subcomitê de Prevenção da Tortura e outros Tratamentos ou Penas Cruéis, Desumanos ou Degradantes - CAT/OP/BRA/R.1,fevereiro de 2012. Disponível em: <http://www.onu.org.br/img/2012/07/relatorio_SPT_2012.pdf>, acesso em 17.08.2014.

PACHECO, Alcides Marques Porto. Há um retorno do pensamento retribucionista? Sobre a (des)conformidade entre teoria da pena, política punitiva e legitimação. Revista Brasileira de Ciências Criminais, São Paulo, n. 84, p. 227-270, maio/jun. 2010.

PANCHERI, Ivanira. Medidas de segurança. Revista Brasileira de Ciências Criminais, São Paulo, v. 5, n. 20, p.105-112, out./dez. 1997.

PAuKOSKI, Mônica Ribeiro de Souza. Interface da Saúde Mental em questão de Justiça e o ponto de vista do Poder Judiciário. In: Conselho Regional DE Psicologia DA 6a ReGiÃo (org.). Políticas de saúde mental e juventude nas fronteiras psi-jurídicas, São Paulo: CRP SP, 2011. p. 15-20.

PeÑa Mateos, Jaime. Antecedentes de la prisión como pena privativa de libertad en Europa hasta el siglo XVII. In: GARCíA VALDÉs, Carlos (dir.). História de la prisión: teorías economicistas, crítica - curso de doctorado. Madrid: Edisofer, 1997. p. 6378.

PEREIRA, Sarah Caroline de Deus. Reforma psiquiátrica versus sistema de justiça criminal: a luta pela efetividade dos direitos humanos ao louco infrator. Revista de Estudos Jurídicos UNESP, Franca, v. 16, n. 23, p.311-328, jan./jul. 2012.

Pietrocolla, Luci Gati; Sinhoretto, Jacqueline; CAStro, Rosa. O judiciário e a comunidade: prós e contras das medidas sócio-educativas em meio aberto. São Paulo: IBCCRIM - Instituto Brasileiro de Ciências Criminais, 2000.

PINTO, Ricardo Matías; RofRAnO, Gustavo Jorge. Aspectos jurídicos de la internación de pacientes mentales. In: Covelli, José Luis et al. Imputabilidad y capacidad de 
culpabilidad: perspectivas médicas e jurídico-penales. Buenos Aires: Dosyuna, 2009. p. 579-592.

Prade, Péricles. Limitação constitucional das penas cruéis. Cadernos de Direito Constitucional e Ciência Política, São Paulo, n. 16, p. 114-118, jul./set. 1996.

PrADO, Geraldo. Violência infanto-juvenil e os processos de vitimização. In: KosovsKI, Ester; SÉGUIN, Elida (Coords). Temas de vitimologia. Rio de Janeiro: Lumen Juris, 2000. p.123-129.

PRADO, Luiz Regis. Multa penal: doutrina e jurisprudência. 2. ed. São Paulo: Revista dos Tribunais, 1993.

QueIROZ, Paulo de Souza. Direito penal: parte geral. 6. ed. Rio de Janeiro: Lumen Juris, 2010.

QueIrOZ, Paulo de Souza. Inconstitucionalidade das medidas de segurança?. Boletim dos Procuradores da República, Brasília, ano VI, no 70, p. 22-23, abr. 2006.

QueIroz, Paulo de Souza. Penas e medidas de segurança se distinguem realmente?. Boletim IBCCRIM, São Paulo, v. 12, n. 147, p. 15-16, fev. 2005.

QUEIROZ, Rafael Mafei Rabelo. A modernização do direito penal brasileiro: sursis, livramento condicional e outras reformas do sistema de penas clássico no Brasil, 19241940. São Paulo: Quartier Latin, 2007.

RAUTER, Cristina. Manicômios, prisões, reformas e neoliberalismo. Discursos Sediciosos: crime, direito e sociedade, Rio de Janeiro, v. 2, n. 3, p. 71-75, 1997.

Reale JR., Miguel. Penas restritivas. Ciência Penal, Rio de Janeiro, v. 7, n. 1, p. 62-78, 1981. 
Resende FILHO, José. Família e as medidas sócio-educativas. Revista do ILANUD, São Paulo, n. 14, p. 39-41, 2001.

RIBEIRO, Bruno de Morais. O problema da função de reintegração social da pena privativa de liberdade: uma análise à luz dos efeitos do sistema social da prisão sobre o indivíduo. In: Lima, Marcellus Polastri; RIBEIRO, Bruno de Morais (Coord.). Estudos criminais em homenagem a Weber Martins Batista. Rio de Janeiro: Lumen Juris, 2008. p. 33-64.

RivacobA Y RivacobA, Manuel de. Función y aplicación de la pena. Buenos Aires: Depalma, 1993.

RivacobA Y RivacobA Manuel de. Tentaciones, principios y perspectivas para una política criminal en Chile a la altura de los tiempos. In: LuISI, Luiz (et al). Politica criminal y reforma penal. Santiago: Jurídica ConoSur, 1996. p. 25-41.

Robaldo, José Carlos de Oliveira. Penas e medidas alternativas: reflexões políticocriminais. Rio de Janeiro: Juarez de Oliveira, 2007.

Roesler, Cláudia Rosane; LAgE, Leonardo Almeida. A argumentação do STF e do STJ acerca da periculosidade de agentes inimputáveis e semi-imputáveis. Revista Brasileira de Ciências Criminais, São Paulo, v. 21, n. 105, p.13-56, nov./dez. 2013.

RosA, Alexandre Morais da. Aplicando o ECA: felicidade e perversão sem limites. Revista Brasileira de Ciências Criminais, São Paulo, v. 58, p. 15-28, jan./fev. 2006.

RosSETTI, Janora Rocha. Da prescrição da medida de segurança. Revista da Procuradoria Geral do Estado de São Paulo, São Paulo, n. 40, p.185-198, dez. 1993.

RUIZ RodRÍGUEZ, Ignacio. Evolución histórica de las penas privativas de libertad. In: García VALDÉs, Carlos (dir.). História de la prisión: teorías economicistas, crítica - curso de doctorado. Madrid: Edisofer, 1997. p. 79-90. 
SÁ, Alvino Augusto de. A "ressocialização" de presos e a terceirização de presídios: impressões colhidas por um psicólogo em visita a dois presídios terceirizados. Revista da Fundação Escola Superior do Ministério Público do Distrito Federal $e$ Territórios, Brasília, v. 11, n. 21, p. 13-23, jan./jun. 2003.

SÁ, Alvino Augusto de. Concepção de crime como expressão de uma história de conflitos: implicações na reintegração social dos condenados à pena privativa de liberdade. Revista da ESMESC: Escola Superior da Magistratura do Estado de Santa Catarina, Florianópolis, v. 7, n. 11, p. 169-178, 2001.

SÁ, Alvino Augusto de. Criminologia clínica e psicologia criminal. São Paulo: Revista dos Tribunais, 2007.

SÁ, Alvino Augusto de; Alves, Jamil Chaim; Zimmaro, Rafael Barone. Medidas de segurança: necessárias reflexões pós-advento da Lei de Reforma Psiquiátrica (Lei 10.216/2001). Boletim IBCCRIM, São Paulo, v. 21, n. 249, p.11-12, ago. 2013.

SAAD-DINIZ, Eduardo. A proteção penal do menor: entre a medida socioeducativa e a repressão ao inimigo. Revista Magister de Direito Penal e Processual Penal, Porto Alegre, v. 8, n. 45, p. 71-82, dez./jan. 2012.

SAntoro FILHo, Antonio Carlos. Fundamentos de direito penal: introdução crítica, aplicação da lei penal, teoria do delito. São Paulo: Malheiros, 2003.

SANTORO FILHO, Antonio Carlos. Internações involuntárias ou perpétuas: a questão da unidade experimental de saúde, mai. 2013. Disponível em < http://jus.com.br/artigos/24356/internacoes-involuntarias-ou-perpetuas-a-questao-daunidade-experimental-de-saude>, acesso em 06.10.2014.

SAntos, Danielle Maria Espezim dos. O controle da natureza pedagógica das medidas socioeducativas. Revista da ESMESC: Escola Superior da Magistratura do Estado de Santa Catarina, Florianópolis, v. 19, n. 25, p. 47-70, 2012. 
SANTOS, Nivaldo dos; GARCiA, Thaís Aurélia. O tratamento constitucional da tortura e a violação da dignidade da pessoa humana. Revista da Faculdade de Direito da UFG, Goiânia, v. 32, n. 2, p.75-83, jul./dez. 2008.

São Paulo (Estado). Procuradoria Geral do Estado. Grupo Penal do Serviço de APOIO JURÍrICO; SOARES, Flávia D'Urso Rocha (relat.). O sistema progressivo de cumprimento da pena e a ofensa às garantias constitucionais (jurisprudência comentada). Revista Brasileira de Ciências Criminais, São Paulo, v. 1, n. 4, p. 154-157, out./dez. 1993.

SARAIVA, João Batista Costa. Adolescente em conflito com a lei: da indiferença à proteção integral; uma abordagem sobre a responsabilidade penal juvenil. $3^{\mathrm{a}}$ ed. Porto Alegre: Livraria do Advogado, 2009.

Saraiva, João Batista Costa. Compêndio de direito penal juvenil: adolescente e ato infracional. $3^{\mathrm{a}}$ ed. Porto Alegre: Livraria do Advogado, 2006.

SheCAIRA, Sergio Salomão. Penas alternativas. In: DotTI, René Ariel; REALE JR., Miguel; Toledo, Francisco de Assis; Shecaira; Sergio Salomão; AzEvedo; David Teixeira de; LOPES, Mauricio Antonio Ribeiro. (Orgs.). Penas restritivas de direitos: Críticas e comentários às penas alternativas. São Paulo: Revista dos Tribunais, 1999. p. 151-262.

ShECAIRA, Sérgio Salomão. Sistema de garantias e o Direito Penal Juvenil. São Paulo: Revista dos Tribunais, 2008.

ShECAIRA, Sérgio Salomão; CORRÊA JR, Alceu. Pena e constituição: aspectos relevantes para sua aplicação e execução. São Paulo: Revista dos Tribunais, 1995.

ShECAIRA, Sérgio Salomão; CORRÊA JR., Alceu. Teoria da pena: finalidades, direito positivo, jurisprudência e outros estudos de ciência criminal. São Paulo: Revista dos Tribunais, 2002. 
SiCA, Leonardo. Direito penal de emergência e alternativas à prisão. São Paulo: Revista dos Tribunais, 2002.

SIlva, Aurélia Carla Quiroga; Gomes, Francisco de Assis Cabral. A cessação da periculosidade e a aplicabilidade da medida de segurança por prazo indeterminado sob as óticas constitucional e penal. Revista Direito e Liberdade, Mossoró, v. 10, n. 1, p. 63-65, jan./jun. 2009.

Silva, José Afonso da. Curso de Direito Constitucional positivo. 29a ed. São Paulo: Malheiros, 2007.

Silva, José Geraldo da. Teoria do Crime: história do direito penal, a lei penal. $4^{\mathrm{a}}$ ed. rev. atual. ampl. Campinas: Millennium, 2010.

Silva, Martinho Braga Batista e. O desafio colocado pelas pessoas em medida de segurança no âmbito do SUS: a experiência do PAILI-GO. MPD Dialógico: Revista do Movimento Ministério Público Democrático, São Paulo, v. 8, n. 36, p. 32-33, 2012.

Silva, Roberto Baptista Dias da. Abolicionismo penal e os adolescentes no Brasil. In: Silva, Roberto Baptista Dias da; PASSETTI, Edson (Org.). Conversações abolicionistas. São Paulo: IBCCRIM / PEPG de Ciências Sociais da PUC-SP, 1997. p. 129-138.

SIRVINSKAS, Luís Paulo. Introdução ao estudo do direito penal: evolução histórica, escolas penais, valores constitucionais, princípios penais e processuais e direitos humanos. São Paulo: Saraiva, 2003.

SouZA, José Francisco Fischinger Moura de. Internação: substituição por tratamento ambulatorial: admissibilidade. Revista Síntese de Direito Penal e Processual Penal, Porto Alegre, v. 3, n. 17, p. 58-63, dez./jan. 2003. 
Sposato, Karyna Batista. Gato por lebre: a ideologia correcional no Estatuto da Criança e do Adolescente. Revista Brasileira de Ciências Criminais, São Paulo, v. 58, p. 133-151, jan./fev. 2006 (a).

Sposato, Karyna Batista. O direito penal juvenil. São Paulo: Revista dos Tribunais, 2006 (b).

Sposato, Karyna Batista. O jovem: conflitos com a lei; a lei : conflitos com a prática. Revista Brasileira de Ciências Criminais, São Paulo, v. 8, n. 30, p. 109-114, abr./jun. 2000.

Sposato, Karyna Batista. Só se educando. Revista do ILANUD, São Paulo, n. 12, p. 13-16, 1998.

SteINER, Sylvia Helena. A prevenção do crime de tortura no cenário do direito internacional. Revista Brasileira de Ciências Criminais, São Paulo, v. 99, p. 299-323, nov./dez. 2012.

SteINER, Sylvia Helena. O Tribunal penal internacional, a pena de prisão perpétua e a constituição brasileira. In: Escritos em homenagem a Alberto Silva Franco. São Paulo: Revista dos Tribunais, 2003.

SyDOw, Spencer Toth. Retratos do regime semiaberto. Revista Magister de Direito Penal e Processual Penal, Porto Alegre, v. 10, n. 56, p. 104-112, out./nov. 2013

SZNICK, Valdir. Direito penal na nova constituição: terrorismo, pena de morte, tortura racismo, confisco - banimento. São Paulo: Ícone, 1993.

TeIXEIRA, Caroline Köhler. As medidas socioeducativas do estatuto da criança e do adolescente e seus parâmetros normativos de aplicação. Revista da ESMESC: Escola Superior da Magistratura do Estado de Santa Catarina, Florianópolis, v. 20, n. 26, p. 151202, 2013. 
Toledo, Francisco de Assis. Aplicação da pena: pena alternativa ou substitutiva. In: DotTi, René Ariel; Reale JR., Miguel; Toledo, Francisco de Assis; SheCAIRA; Sergio Salomão; Azevedo; David Teixeira de; LoPes, Mauricio Antonio Ribeiro. (Orgs.). Penas restritivas de direitos: Críticas e comentários às penas alternativas. São Paulo: Revista dos Tribunais, 1999. p. 129-148.

Toledo, Francisco de Assis. Princípios básicos de direito penal. $5^{\text {a }}$ ed. $15^{\mathrm{a}}$ tir. São Paulo: Saraiva, 2010.

TORRES, Andrea Almeida. Críticas ao tratamento penitenciário e a falácia da ressocialização. Revista de Estudos Criminais, Porto Alegre, v. 7, n. 26, p. 107-125, jul./set. 2007.

TuCCI, Rogério Lauria. Suspensão condicional da pena. Ciência Penal, Rio de Janeiro, v. 6, n. 2, p. 79-103, 1980.

VAloIS, Luis Carlos. Conflito entre ressocialização e o princípio da legalidade na execução penal. Rio de Janeiro: Lumen Juris, 2013.

VARALDA, Renato Barão. Penas Restritivas de Direitos - Inovações. Boletim IBCCRIM, São Paulo, n. 75 - encarte, p.VII-VIII, fev. 1999.

VARGas, Fernanda de; Silva, Juliana Kerch da; VAsconcellos, Silvio José Lemos. Adolescente em conflito com a lei: um estudo com adolescentes que cumprem medidas socioeducativas em meio aberto. Revista de Estudos Criminais, Porto Alegre, ano 11, n. 48, p. 113-128, jan./mar. 2013.

ViannA, Guaraci de Campos. Responsabilidade penal dos adolescentes e medidas socioeducativas. Revista da EMERJ, Rio de Janeiro, v. 10, n. 40, p. 210-242, 2007.

VIDAL, Luis Fernando Camargo de Barros. Medidas sócio-educativas. Revista Brasileira de Ciências Criminais, São Paulo, v. 10, n. 37, p. 191-207, jan./mar. 2002. 
VIEIRA, Vanderson Roberto. "Medidas de segurança" por tempo indeterminado (perpétuas): impossibilidade constitucional. In: PAULA, Marco Aurélio Borges de; Magrini, Rachel de Paula (Coord.). Estudos de direito público. Campo Grande: Cepejus, 2009. p. 678-684.

Villacampa Estiarte, Carolina; Torres Rosell, Núria; LuQue ReinA, María Eulália. Penas alternativas a la prisión y reincidencia: un estudio empírico. Navarra: Aranzadi, 2006.

VOLPI, Mario. O adolescente e o ato infracional. Revista do ILANUD, São Paulo, n. 14, p.21-32, 2001.

VOLPI, Mario (org.). O adolescente e o ato infracional. $3^{\text {a }}$ ed. São Paulo: Cortez / INESC, 1999.

VON MÜNCH, Ingo. La dignidad del hombre en el derecho constitucional alemán. Foro, Madri, n. 9, p. 107-123, 2009.

Zaffaroni, Eugenio Raúl; et al. Direito penal brasileiro: primeiro volume - teoria geral do direito penal. $3^{\text {a }}$ ed. Rio de Janeiro: Revan, 2006.

Zaffaroni, Eugenio Raúl; PIERAngeli, José Henrique. Manual de direito penal brasileiro: parte geral. 8. ed. São Paulo: Revista dos Tribunais, 2009.

ZAPATA, Fabiana Botelho. Internação: medida socioeducativa? Reflexões sobre a socioeducação associada à privação de liberdade. Revista da Defensoria Pública, São Paulo, Ed. especial temática sobre infância e juventude, n. 3, p. 43-50, 2008.

Zurlo, Roberta; Silva, Marcelo Motta Coelho. A mudança do conceito de disciplina na execução penal: a institucionalização do RDD (Regime Disciplinar Diferenciado). Revista Transdisciplinar de Ciências Penitenciárias, Pelotas, v. 4, n. 1, p. 27-37, jan./dez. 2005. 